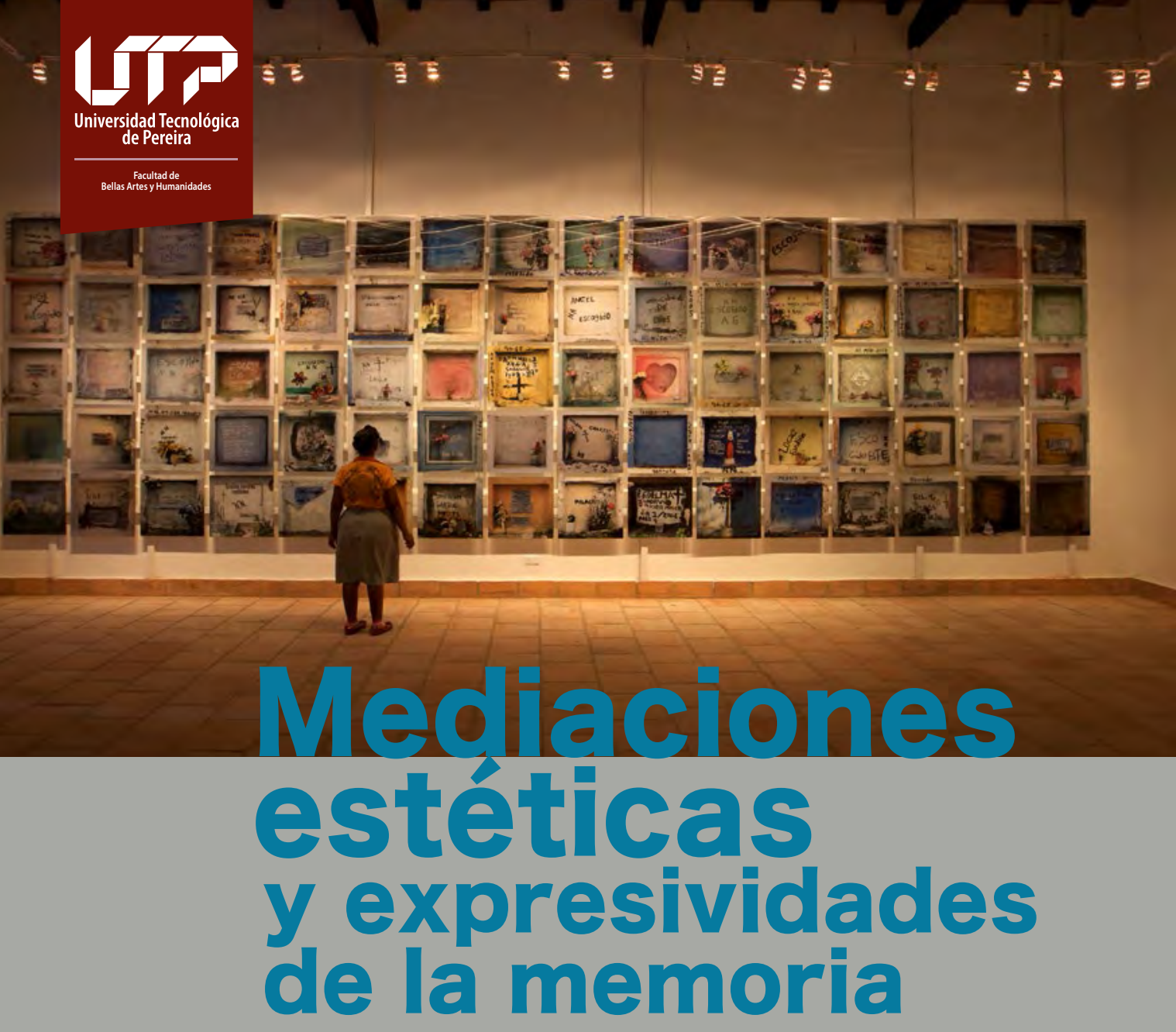

Felipe Martínez

Margarita Calle

Juan Manuel Martínez

Editorial UTP

Colección Trabajos de Investigación 


\section{Felipe Martínez}

Manizales (Caldas), 1981. Doctor en Estudios Sociales por la Universidad Externado de Colombia. Licenciado en Filosofía y Letras de la Universidad de Caldas. Es profesor titular transitorio de tiempo completo del Departamento de Humanidades, Facultad de Bellas Artes y Humanidades de la Universidad Tecnológica de Pereira, donde hace parte de Grupo de investigación Arte y Cultura. Sus artículos han sido publicados en revistas especializadas.

felipemartinez@utp.edu.co

\section{Margarita Calle}

Salgar (Antioquia), 1969. Doctora en Humanidades por la Universidad del Valle. Es profesora titular del Departamento de Humanidades, Facultad de Bellas Artes y Humanidades de la Universidad Tecnológica de Pereira, donde dirige la Maestría en Estética y Creación, y el grupo de investigación Arte y Cultura. Ha publicado los libros: Metáforas urbanas. El artista y la ciudad, 2003; Perspectivas históricas de las artes plásticas en Pereira, 2006; Mutaciones y registros. Desplazamientos y convergencias del arte contemporáneo en Colom bia, 2011; Pereira: el álbum de su historia, 2013. Sus artículos han sido publicados en revistas especializadas.

aumar@utp.edu.co

\section{Juan Manuel Martínez}

Manizales (Caldas), 1982. Doctor en Ciencias Sociales por la Universidad de Buenos Aires. Magister en Antropología Social de la Universidad de Antioquia y Profesional en Filosofía y Letras de la Universidad de Caldas. Es profesor transitorio de tiempo completo del Departamento de Humanidades de la Universidad Tecnológica de Pereira, donde integra el grupo de Investigación Arte y Cultura. Es coautor del libro Rituales, rutinas y nostalgias en el centro de Pereira, 2017, y autor de los capítulos de libro "Crimen organizado y violencia homicida en ciudades intermedias", 2020 y "Paces, justicia y convivencia social: un abordaje interdisciplinar", 2019. Sus artículos han sido publicados en revistas especializadas. juanmanuel1@utp.edu.co

\section{Mediaciones estéticas y expresividades de la memoria}




\section{Mediaciones estéticas y expresividades de la memoria}

Felipe Martínez

Margarita Calle

Juan Manuel Martínez

\section{עז \\ Universidat Tencologica}

Colección Trabajos de Investigación Facultad de Bellas Artes y Humanidades Departamento de Humanidades 2021 
ISBN: 978-958-722-533-4

1. Estética creativa 2. Violencia política 3. Política social - Colombia 4. Creación artística 5. Conflicto armado - Colombia 6. Expresiones estéticas 7. Producción artística

CDD. 701.18

(c) Mediaciones estéticas y expresividades de la memoria

(c) Felipe Martínez - felipemartinez@utp.edu.co

c Margarita Calle - aumar@utp.edu.co

(c) Juan Manuel Martínez - juanmanuel1@utp.edu.co

(c) Universidad Tecnológica de Pereira

Primera edición, 201921

ISBN 978-958-722-533-4

eISBN 978-958-722-534-1

Proyecto de investigación:

“Mediaciones estéticas y expresividades de la memoria ", código 1-17-3

Universidad Tecnológica de Pereira

Vicerrectoría de Investigaciones, Innovación y Extensión

Editorial Universidad Tecnológica de Pereira

\section{Coordinador editorial}

Luis Miguel Vargas Valencia

luismvargas@utp.edu.co

Conmutador 3212221 Ext. 381

Cra. 27 No. 10-02 Los Álamos, Pereira, Colombia

www.utp.edu.co

Diseño y diagramación

Margarita Calle

\section{Portada}

Juan Manuel Echavarría, Réquiem NN, Serie fotográfica, 2006-2015

Impresión y acabados

Panamericana Formas e Impresos S.A.
El equipo de investigadores agradece a los artistas, colectivos sociales, organizaciones de la sociedad civil y demás personas vinculadas a procesos expresivos y de resignificación de la memoria individual y colectiva, por habernos permitido un acercamiento detenido a su trabajo y la posibilidad de registrar sus experiencias en función del horizonte de este proyecto.

Al fotógrafo Rodrigo Grajales por aportar a la reconstrucción de la narrativa desplegada por el “Colectivo Magadalenas por el Cauca” y contribuir, con su trabajo visual, a la configuración de un archivo actualizado sobre los procesos de resistencia y memoria histórica en algunos territorios más afectados por la violencia política del país.

A la Vicerrectoría de Investigaciones, Innovación y Extensión de la Universidad Tecnológica de Pereira, por el apoyo brindado para desarrollar el proyecto de investigación Mediaciones estéticas y expresividades de la memoria y agenciar la publicación de su resultado.

A los colegas del Departamento de Humanidades de la UTP con quienes discutimos los avances del proyecto y ampliamos el sentido de las reflexiones aquí consignadas. 


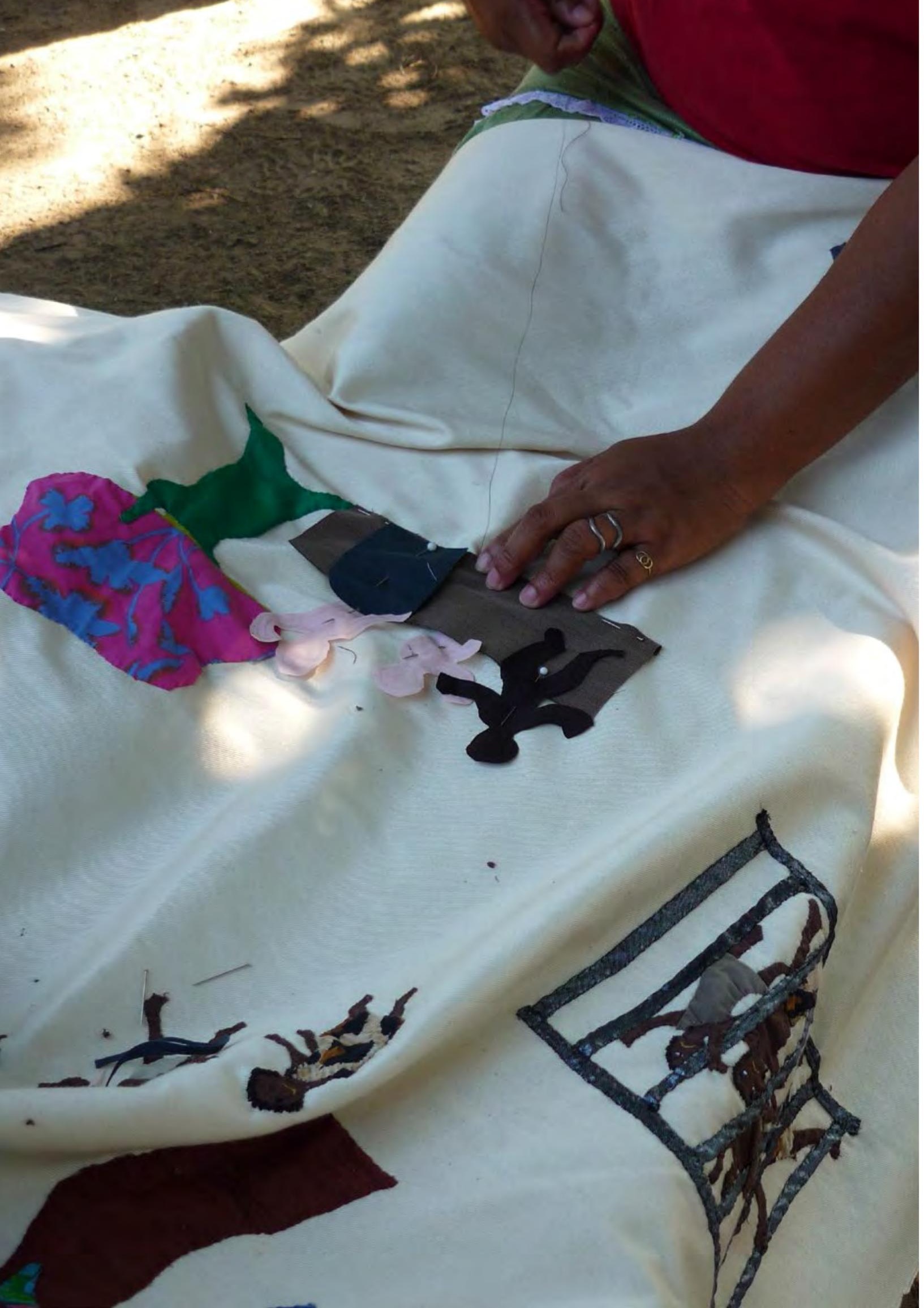

Contenido

Introducción

Capítulo 1

Mediaciones artísticas. Resignificaciones de lo político y

emergencia expresiva del testimonio.

El arte frente a la violencia: Poéticas, políticas y

formas de interacción.

Desenterrar y hablar

Reconocer el dolor de los demás

El río como testigo silencioso

Testigos, indicios y ritualidades. Mediaciones del arte sobre la violencia política en Colombia.

Rostro y testimonio

Ritualidades a la orilla del río

Ruinas, indicios y rastros de humanidad

Capítulo 2

Mediaciones estéticas. Entre las precariedades sociales

y los flujos imaginativos de la expresividad estética.

Influjos de la estética

Maneras sensibles del ser y del hacer

La guerra que no hemos visto

Magdalenas por el Cauca

327 alumbramientos por las huellas del olvido

Prácticas de cohesión y resistencia: crear para sobrevivir 
Entretejer el afecto

Experiencias y acciones comunes

\section{Capítulo 3}

Expresividades de la memoria.

La violencia como dispositivo creador.

De la representación al ritual

Una revisión al concepto

La mediación estética de la víctima,

el ritual como recurso simbólico.

El ritual como metáfora, mediación política

Del territorio al reasentamiento

Las mediaciones estéticas y las expresividades de la memoria A manera de epílogo

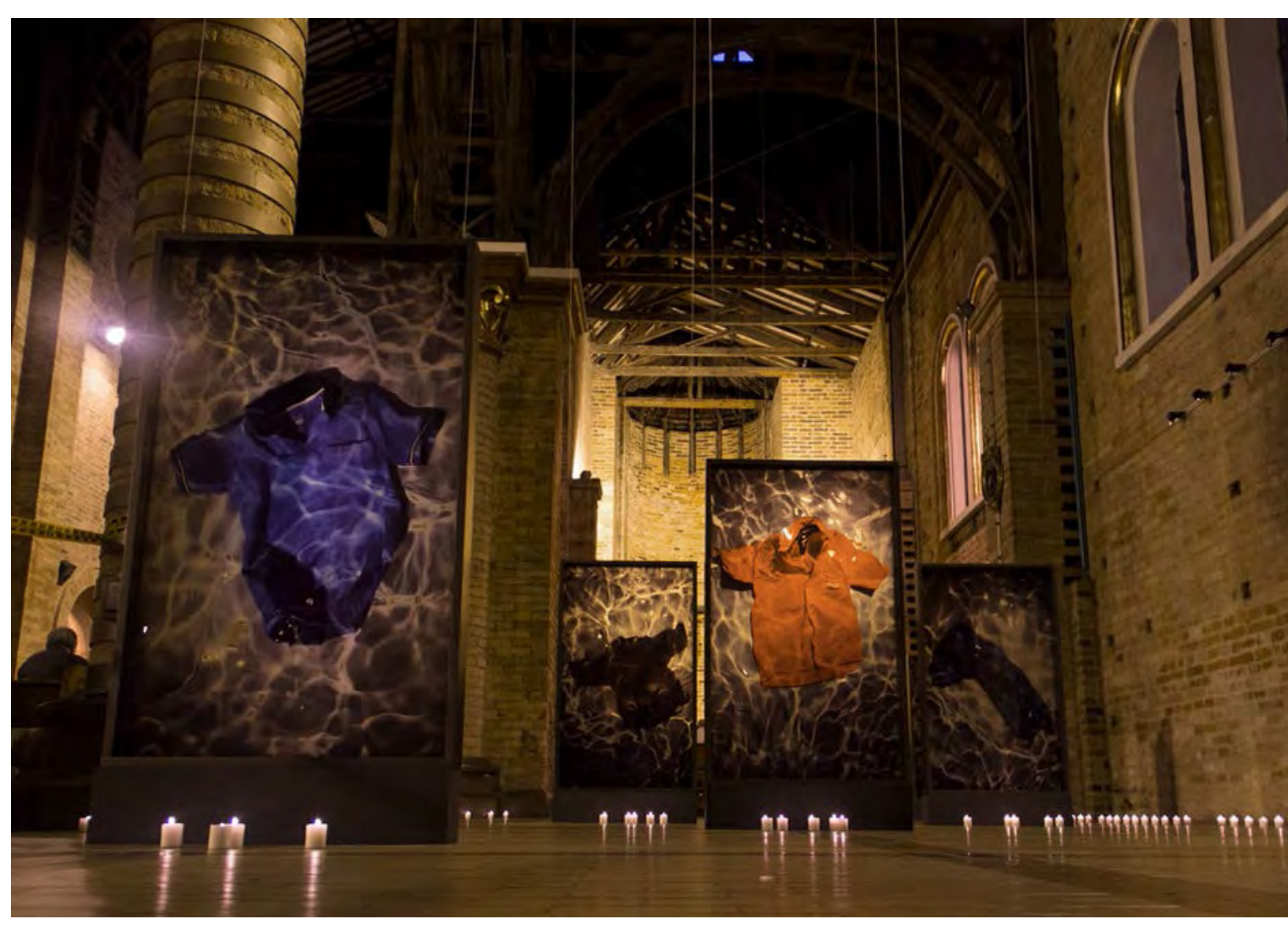




\section{Introducción}

Las tramas y las formas de inscripción de la memoria dependen de la intensidad de las experiencias vividas y de los recursos simbólicos y narrativos de los que se está provisto para traducir y resignificar los recuerdos. Su reflexión compromete la pregunta por las maneras como se configuran en nuevos soportes y materialidades, los vínculos y tensiones entre los hechos, las formas de nombrar las experiencias y los modos de visibilizar sus significados. Por esto teóricos como Elizabeth Jelin, aclaran que la memoria no se relaciona con una reconstrucción objetiva del pasado, sino con su reinterpretación, desde las posibilidades del presente y con las expectativas de proyección en el futuro. En este sentido, advierte Jelin (2002):

El pasado que se rememora y se olvida es activado en un presente y en función de expectativas futuras (...). El pasado ya pasó, es algo de-terminado, no puede ser cambiado. El futuro, por el contrario, es abierto, incierto, indeterminado. Lo que puede cambiar es el sentido de ese pasado, sujeto a reinterpretaciones ancladas en la intencionalidad y en las expectativas hacia ese futuro. (p. 39)

De este modo, nombrar el pasado, asignarle sentido a experiencias y acontecimientos anclados en un tiempo y espacio anterior, implica necesariamente resignificar desde el presente esa experiencia que se traduce en recuerdo. Traer a la memoria implica entonces una especie de compromiso implícito -o explícito- con lo por-venir, con un futuro todavía en ciernes, pero en el cual se proyectan nuevas valoraciones y expectativas.

Ahora bien, en el contexto de sociedades que han atravesado conflictos de orden social o político, la dimensión colectiva o histórica de la memoria representa, simultáneamente, la posibilidad de iluminar el pasado y el riesgo de proyectar nuevas sombras sobre él. Implica, también, la acción 
de reconstruir algunos acontecimientos desde una determinada perspectiva -siempre parcial e incompleta-y la posible supresión de otros hechos y matices que permanecen como vacíos estructurales, bien sea por ausencia de información, por la acción inefable del olvido, bien por el silencio o bien porque, simplemente, no encajan en un relato o en una intencionalidad interpretativa frente a lo ocurrido.

Lo anterior no resultaría del todo problemático si no fuera porque, en muchos casos, las versiones que empiezan a consolidarse o a imponerse como conformaciones colectivas de la memoria, son agenciadas por organismos, fuerzas políticas o sectores sociales hegemónicos, cuyo interés es revestir tales relatos con un halo de verdad o aceptación totalizadora (represora), en aras de reforzar el lugar de enunciación y los recursos expresivos empleados, y como estrategia para clausurar las múltiples posibilidades de su comprensión o resignificar lo por-venir.

En el caso particular de la sociedad colombiana, la emergencia y confrontación de iniciativas de memoria colectiva e histórica sobre el conflicto armado interno se ha activado de forma particular en las dos últimas décadas, en el contexto de una forma bastante compleja de transicionalidad política. Un primer escenario de activación se deriva del proceso de negociación entre el gobierno de Álvaro Uribe Vélez y algunas de las estructuras paramilitares en el año 2002. De este proceso de negociación se derivó la creación e implementación de la Ley de justicia y paz en el 2005, la creación de la Comisión Nacional de Reparación y Reconciliación, que daría lugar, posteriormente, al Grupo de Memoria Histórica y, por último, al Centro Nacional de Memoria Histórica (CNMH). El segundo escenario de activación es producto de los diálogos y la concreción del Acuerdo final para la terminación del conflicto y la construcción de una paz estable y duradera, suscrito entre el gobierno de Juan Manuel Santos y las FARC-EP (Fuerzas Armadas Revolucionarias de Colombia. Ejército del Pueblo). De estos acuerdos se desprende, a su vez, la creación del Sistema Integral de Verdad, Justicia, Reparación y No Repetición (SIVJRNR), del cual hacen parte la Jurisdicción Especial para la Paz (JEP), la Unidad para la Búsqueda de Personas Dadas por Desaparecidas (UBPD) y la Comisión para el Esclarecimiento de la Verdad, la Convivencia y la No Repetición, mejor conocida como Comisión de la Verdad.
Ahora bien, lo problemático de estos escenarios de transición política tiene que ver, entre otras cosas, con el hecho de que los procesos de diálogo y negociación de paz mencionados no han conseguido asegurar el paso de una condición generalizada de violencia y conflicto armado interno a la dejación plena y definitiva de las armas por parte de todos los actores involucrados en el conflicto. En medio de este ámbito complejo, asistimos a la construcción del relato del pasado con el cual las próximas generaciones van a comprender nuestro presente. Por eso se hace urgente construir las categorías y las formas de mediación frente a los hechos y acontecimientos que configuran nuestra experiencia de la violencia política, que van a permitir la creación de rutas de indagación y conocimiento sobre nuestras subjetividades en juego y nuestras conformaciones colectivas, como posibilidad para abrir o cerrar las opciones de verdad, justicia y reparación, en función de las responsabilidades que nos competen como sociedad.

De este modo, la lucha por la memoria histórica es también una lucha por la conquista de los territorios de sentido ligados a los modos de enunciación y expresión por medio de los cuales el pasado se actualiza. Tales territorios de sentido esbozan, desde su capacidad y elocuencia, las claves interpretativas que definen las relaciones entre los hechos y los actores directamente involucrados en su agenciamiento. Al mismo tiempo, dan forma a las narrativas, las prácticas e interpretaciones que darán lugar a las condiciones y proyección del futuro. Esta confrontación de sentidos sobre el pasado y la memoria histórica tiene como escenario la esfera de lo público, entendida aquí como la instancia en la que convergen las formas de expresión y las narrativas, materializadas en conformaciones de carácter académico, político, cultural, artístico, entre otras.

Las prácticas artísticas y las expresiones estéticas han devenido campo de comprensión clave para valorar la manera como los grupos sociales exteriorizan sus expectativas de sentido y ponen en relación las experiencias afectivas que le dan soporte vivencial a su existencia. En contextos de gran complejidad como los que ha generado la violencia política y el conflicto armado en Colombia, es común encontrar que las comunidades recurren con frecuencia a prácticas simbólicas, comportamientos afectivos o for- 
mas de agenciamiento de la vida social, cuyo valor no se puede entender por fuera del marco reflexivo y sensible que nos ofrece la estética.

En el mismo camino, una parte de los procesos creativos que ocupan a los artistas contemporáneos, se han afianzado en vínculos estrechos construidos en torno a la memoria de las víctimas de la violencia. Esto ha contribuido a propiciar un doble juego configurador de carácter estético y político: por un lado, la materialización de procesos expresivos y de traducción de experiencias derivadas del drama que viven las víctimas, relacionados con los duelos no resueltos, la ausencia, la pérdida o el despojo; por otro lado, la consolidación de un archivo de registros, enteramente transmisible, que deviene memoria colectiva o sistema de referencias interindividual y que actúa como dispositivo simbólico y testimonial de un contexto y un espacio-tiempo particular.

En coherencia con esto, en el proyecto Mediaciones estéticas y expresividades de la memoria planteamos como apuesta central, la comprensión de algunas de las formas de mediación expresiva construidas por artistas, sobrevivientes y grupos sociales en torno a experiencias ligadas con la violencia política y el conflicto armado en Colombia.

Para tal fin, desplegamos un marco comprensivo que se vale, en primer lugar, de un ejercicio arqueológico que busca determinar las relaciones vinculantes entre las experiencias estéticas y los procesos de representación, elaboración o resignificación que tienen lugar en algunas prácticas artísticas, acciones colectivas o rituales, que han tematizado, de forma directa, la violencia política. En estos procesos sale a flote tanto el trabajo creativo de un grupo de artistas que ha sido capaz de traducir y materializar, en diferentes soportes, la experiencia de las víctimas, la relación con los contextos y las tensiones derivadas del extenso periodo de confrontación entre las diferentes fuerzas políticas del país, como la visibilización de una serie de prácticas y agenciamientos expresivos, inscritos en la experiencia cotidiana de las personas y los grupos sociales afectados por el conflicto armado interno, los cuales patentizan lo que, en la perspectiva de Jacques Rancière (2014), representa un nuevo reparto de lo sensible: una ampliación de las formas de visibilidad y de las condiciones de decibilidad, posible gracias a una redistribución de las maneras de hacer y las opciones emancipadoras de la participación colectiva.
De la misma forma, se proyecta un ejercicio cartográfico, desde el cual se hacen visibles procesos creativos, imágenes, prácticas estéticas y lugares de enunciación derivados de experiencias de interacción entre los artistas y las víctimas, en distintos contextos y espacios geográficos; todo ello con el fin de enunciar puntos de conexión, contrastes y formas particulares de abordar las tensiones, alteridades y significados compartidos, sin perder de vista las implicaciones sociales y políticas que pueden provenir de estos procesos expresivos.

Por último, hacemos referencia a los procesos de mediación de carácter social, en los que las expresividades estéticas devienen dispositivo de relación, estrategia de cohesión y recurso simbólico de actualización de los vínculos fracturados por acciones de ruptura, los cuales resultan claves para revitalizar las memorias individuales y colectivas, en el contexto de una sociedad compleja, cercada por fuerzas en confrontación, en la que los procesos oficiales de restauración de tales vínculos, difícilmente se concretan en el tiempo.

Estos marcos comprensivos dieron pie a tres escenarios centrales de reflexión y conceptualización que, a su vez, configuran los tres capítulos que componen el presente trabajo. En el primer capítulo, titulado Mediaciones artísticas. Resignificaciones de lo político y la emergencia expresiva del testimonio, tomamos como casos de estudio y punto de referencia para el análisis, algunos proyectos de los artistas Juan Manuel Echavarría, Erika Diettes y el Colectivo “Magdalenas por el Cauca”, conformado por Yorlady Ruiz y Gabriel Posada, como pretexto para articular una reflexión en torno al sentido que entrañan los procesos creativos en la mediación de las narrativas de la memoria. La elección de estos artistas y la delimitación de los proyectos escogidos, responde a un reconocimiento del lugar que ha tenido en su obra la construcción de una narrativa en torno a la experiencia de la violencia política en Colombia, que compromete el desplazamiento a zonas geográficas afectadas por las dinámicas de la confrontación armada, los relatos y testimonios de sobrevivientes y familiares de víctimas, y el registro de residuos materiales, simbólicos y expresivos como formas de inscripción de la violencia y sus efectos.

Estas prácticas se ubican en una suerte de frontera, que sitúa los puntos de intersección entre los marcos disciplinares de la investigación social, 
los discursos críticos sobre la violencia política y las posibilidades expresivas de los lenguajes artísticos en relación con la experiencia y los testimonios de las víctimas, los sobrevivientes de actos violentos o los familiares de estos. Desde su accionar, los artistas no buscan representar los hechos, señalar responsables, inventariar los daños, sino, más bien, inscribir un registro en el presente y crear un entorno reflexivo que sirva de enclave para la mediación entre los testimonios, las experiencias concretas y los procesos creativos. Por esta misma vía buscan provocar miradas reflexivas que contribuyan a cuestionar la naturaleza de los conflictos, el tránsito anónimo de los desaparecidos, los éxodos y los desarraigos, para devolverle la densidad a las imágenes y, desde aquí, construir otros escenarios para el duelo y la memoria colectiva.

El segundo capítulo, titulado Entre las precariedades sociales y los flujos imaginativos de laexpresividad estética, enfatiza sobre prácticas estéticas y proyectos creativos de carácter relacional, agenciados por artistas o colectivos transdisciplinares de la sociedad civil, en los que se recurre al testimonio, se interpela al testigo, se recuperan archivos o se despliegan acciones que comprometen el comportamiento afectivo de las personas y las colectividades, para dar lugar a registros y materialidades que actúan como detonantes de una memoria silenciada o clausurada. En este escenario las prácticas estético-artísticas cumplen varias funciones: por un lado, se convierten en un espacio de visibilidad o de señalamiento, fundamental para la resignificación de la memoria de las víctimas y la reconstrucción de una conciencia reflexiva del presente; por otro lado, activan la dinámica de ciertos grupos sociales, la mayoría de las veces marginados de la atención del Estado, que encuentran en los procesos expresivos un dispositivo sensible de relación, clave para cohesionar los vínculos afectivos entre las personas, rotos por la acción de los violentos y la fragmentación paulatina de las comunidades de origen. Propicio, además, para gestionar el drama de los propios victimarios, sometidos a complejos procesos de reintegración o normalización social.

En el contexto de este apartado se abordan tres proyectos artísticos: La guerra que no hemos visto de Juan Manuel Echavarría, Magdalenas por el Cauca y 327 alumbramientos por las huellas del olvido de Gabriel Posada y
Yorlady Ruiz, los cuales se destacan por activar dispositivos de visibilidad y enunciabilidad que actúan como recursos flexibles y plurales, propicios para reescribir las memorias, ya no desde la perspectiva formateada por el relato oficial, sino desde la experiencia directa de los actores del conflicto. A su vez, en este capítulo se vinculan una serie de experiencias e iniciativas sociales, agenciadas desde organizaciones de la sociedad civil, mismas que se valen del potencial pragmático y religante de los procesos creativos, para superar, o por lo menos paliar el impacto de las acciones violentas en el tejido comunitario. Prácticas cotidianas como bordar, tejer, conversar, cocinar, pintar, danzar, entre otras, devienen acción mediada, estrategia política y recurso pedagógico, significativas para anudar la trama de un relato insurgente y las imágenes de una narrativa inédita, que reclama condiciones culturales para su exteriorización y reflexión.

Por último, en el tercer capítulo titulado La violencia como dispositivo creador, se construye una reflexión en torno a expresiones rituales, agenciadas por sobrevivientes del conflicto armado, las cuales proponen formas particulares de materializar, narrar, relatar, exteriorizar algunas de las experiencias y posibilidades de resignificación de la propia vivencia del conflicto, como estrategia íntima y como recurso para registrar, ficcionar o gestionar el recuerdo y los vínculos con un pasado doloroso. En este contexto hacemos referencia, entre muchas prácticas de sentido, a la composición de canciones que re-significan el pasado; la producción de novelas y relatos literarios que dialogan entre una historia vivida y un deseo por apalabrar una experiencia; la construcción de objetos y tejidos que sirven como medio de sustento, pero que también cumplen funciones catárticas; la escritura de diarios o poemas que comprometen la experiencia del duelo, la ausencia o la duración del recuerdo, además de expresiones cotidianas creadas como estrategia para activar, gestionar o resignificar la memoria de las víctimas. Aunque son incalculables los horizontes de la estética como mediación desde la mirada de las víctimas, en este capítulo se delimita el ejercicio a cuatro casos puntuales: uno desde el cuerpo a través del performance, los otros dos desde la escritura por medio de cuentos, poesías y novelas, y el último desde la cotidianidad y el testimonio de actividades colectivas por parte de una organización comunitaria. 
Más allá de caracterizar algunos dispositivos rituales que intervienen en la semántica de la mediación estética, el diálogo entre la elaboración de la víctima -no reconocida como artista-, su proceso de construcción y el producto final, permiten re-pensar la noción de memoria y el modo como tienen lugar los relatos de la historia en el contexto colombiano. En este escenario la reconstrucción de la experiencia del conflicto armado no tiene lugar por la vía del discurso académico; aquí se apela a recursos íntimos que, a su vez, se convierten en un testimonio vivo- creativo, que dan cuenta de la manera como cada sujeto inscribe en diferentes soportes de memoria su propia versión de los acontecimientos, poniendo en juego una mirada particular del pasado y un modo singular de existir (exteriorizar) su condición humana.

Finalmente, en los tres escenarios descritos, a pesar de contener miradas y funciones diversas de la mediación estética, aparece comprometida, en todo caso, una reflexión de fondo, en torno a las formas de materialización de las memorias individuales y colectivas, los vehículos expresivos que les sirven de soporte para su circulación, archivo, transmisión y resignificación en marcos espacio- temporales determinados.

Si bien la condición estética de las experiencias que articulan este trabajo nos impulsan a elegir unas formas de representación que resultan relevantes como aproximación simbólica a la experiencia de la violencia en Colombia, es necesario advertir que las prácticas señaladas en los tres apartes del texto, configuran, sobre todo, formas plurales de registrar y documentar los efectos de la violencia política en los sujetos, en las comunidades y en los territorios. En ellas no se apela a la consignación de un relato objetivo de acontecimientos particulares, sino a la configuración de estrategias de traducción y mediación, que operan como dispositivos de visibilidad y enunciabilidad, bien desde una función simbólica o bien desde una acción performativa, para inscribir gestos y sentidos, allí donde la palabra se revela como un recurso limitado, allí donde el silencio y el olvido impuestos amenazan la posibilidad de la memoria y la recordación.

Las prácticas artísticas y los procesos expresivos comprometidos en esta lectura del presente no constituyen una expresión posterior a la experiencia o al testimonio, sino que intervienen, de forma constitutiva, en el registro y percepción de tales experiencias. Las imágenes no cumplen la función restringida de representar un hecho previamente documentado, sino que, en sí mismas, se constituyen en formas de patentizar, registrar y otorgar sentido a unas experiencias comunes, que se replican de manera incesante en el territorio colombiano. En el contexto de emergencia de estas experiencias, la relación entre estética, arte y política, tematizada por Jacques Rancière (2011), cobra relevancia, pues no solo tendría que ver con la capacidad del dispositivo del arte y la estética de transformar o afectar reflexivamente las formas de ser colectivas, sino con la manera como "las prácticas y las formas de la visibilidad del arte intervienen ellas mismas en el reparto de lo sensible y en su configuración, de donde recortan espacios y tiempos, sujetos y objetos, lo común y singular" (p. 35).

No hay que olvidar, sin embargo, que este recorte de realidad no es ajeno a la emergencia de nuevas tensiones y complejidades relacionadas, entre otras cosas, con la definición del lugar de enunciación de los creativos, de los sobrevivientes y los familiares de las víctimas de la violencia, pero también en relación con las interacciones y transacciones de sentido arriesgadas, entre formas tan plurales de agenciamiento social, cultural y político. También es necesario reconocer que, en el caso de las prácticas estético-artísticas a las que hemos hecho alusión en este trabajo, por más que se explicite la intencionalidad del artista cuando se aproxima a la experiencia y al testimonio del otro, es su voz y su gesto expresivo el que prevalece. Si bien no podemos desconocer que estos procesos evidencian un posicionamiento distinto por parte de los artistas y creativos, que da pie a una relación de mayor proximidad con los contextos geográficos y sociales en los que han ocurrido hechos violentos, es necesario advertir su lugar de enunciación en la perspectiva que hilvana y define las formas expresivas de esta mediación. 
Hay una política de la estética en el sentido en que las formas nuevas de circulación de la palabra, de exposición de lo visible y de producción de los afectos determinan capacidades nuevas, en ruptura con la antigua configuración de lo posible. Hay así una política del arte que precede a las políticas de los artistas, una política del arte como recorte singular de los objetos de experiencia común, que opera por sí misma, independientemente de los anhelos que puedan tener los artistas de servir a tal o cual causa.

J. Rancière (2010)

...ese dibujo se hace de lo que pasó, el hecho victimizante. Se hace, pero hoy entiendo que se toma una segunda persona, se saca ese dolor, esa pena que tú no quieres recordar porque te

lastima, pero es necesario hacerlo, para que se sane la herida; tú lo sacas de allí y lo pones en una segunda persona, entonces ya no ves que eres tú, ya tú lo puedes manipular, lo puedes cortar con la tijera, lo puyas con los alfileres, lo puyas con la aguja, lo coses y lo vas sacando de ti, y te va permitiendo hacer esa catarsis.

J. Ruiz (Tejedora Mampuján, 2016)

La cuestión no consiste en aproximar los espacios del arte al no arte y a los excluidos del arte. La cuestión consiste en utilizar la extraterritorialidad misma de esos espacios para describir nuevos disensos, nuevas maneras de luchar contra la distribución consensual de competencias, de espacios y funciones. El consenso es ante todo la distribución de esferas y de competencias. La fuerza del espacio del arte en relación con esto consiste en ser un espacio metamórfico, dedicado no a la coexistencia de las culturas sino a la mezcla de las artes, a todas las formas mediante las cuales las prácticas de las artes construyen hoy día espacios comunes inéditos. 


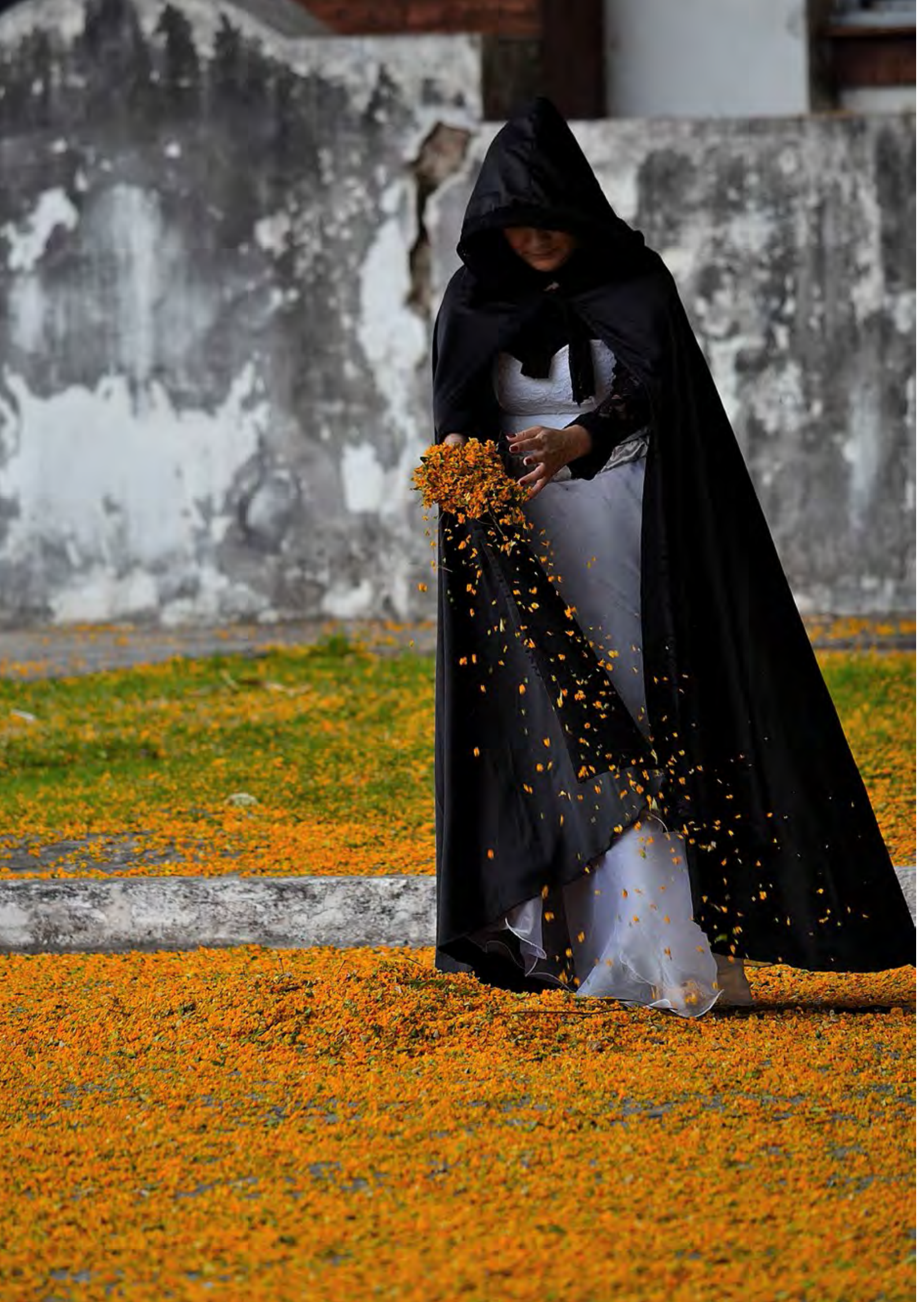

Capítulo 1

\section{Mediaciones artísticas}

Resignificaciones de lo político y emergencia expresiva del testimonio

Felipe Martínez 
El arte no es politico, en primer lugar, por los mensajes y los sentimientos que transmite acerca del orden del mundo. No es político, tampoco, por la manera en que representa las estructuras de la sociedad, los conflictos o las identidades de los grupos sociales. Es político por la misma distancia que toma con respecto a sus funciones, por la clase de tiempos y de espacio que instituye, por la manera en que recorta este tiempo y puebla este espacio.

J. Rancière (2011)

En el contexto colombiano de los últimos 70 años, las prácticas artísticas han abordado de forma insistente el tema del conflicto armado y la violencia política, lo cual no resulta extraño si tenemos en cuenta que tales fenómenos han atravesado de forma dramática nuestra historia colectiva reciente. Desde diversas perspectivas y formas expresivas, los artistas han buscado hacer visibles aspectos derivados de la violencia, bien desde posturas críticas o bien desde miradas evocadoras y reflexivas que aluden a los efectos de la violencia sobre los grupos sociales y los territorios.

De este modo, el arte configura, a partir de sus procesos creativos, formas de mediación frente a las experiencias relacionadas con la violencia política en Colombia y, por esta vía, contribuye a la compleja tarea de darle dimensiones expresivas a la memoria colectiva, enfrentando las tensiones y complejidades que ello implica. Historiadores del arte como Ivonne Pinni (1986), Álvaro Medina (1999), Margarita María Malagón (2010), han hecho visibles algunos de estos rasgos expresivos, relacionados con temporalidades y énfasis temáticos derivados de la producción artística en las últimas décadas. Muestra de ello es la clasificación realizada por Medina (1999) en el contexto del trabajo de revisión histórica para la propuesta curatorial de la emblemática exposición "El arte y la violencia en Colombia desde 1948”, que tuvo lugar en el Museo de Arte Moderno de Bogotá en 1999.

En esta clasificación, Medina reúne una parte importante de la producción artística relacionada con la violencia política entre 1948 y 1999, tomando como hilo conductor una serie de rasgos contextuales y expresivos, relacionados con etapas y dinámicas históricas más o menos concretas a saber: El arte y la violencia bipartidista, que alude a los trabajos artísticos creados entre 1948 y 1959. El arte revolucionario, que hace referencia a la producción artística enmarcada entre los años 1960 y 1979, y la violencia narcotizada que alude a la producción artística entre 1980 y 1999. Como puede verse, cada periodo corresponde a un énfasis que, aunque no alcanza a dar cuenta de la complejidad de los fenómenos y acontecimientos de cada época de referencia, enmarca unas condiciones particulares de las prácticas artísticas en relación con el contexto social y político del país.

Por su parte, Margarita María Malagón, al retomar, hasta cierto punto, la clasificación realizada por Medina, hace mayor énfasis en los tránsitos y variaciones expresivas. En este caso, asume como punto de referencia ciertos contrastes entre las expresiones artísticas de los años sesenta, frente a la producción creativa de algunos artistas de los años ochenta y noventa. Al respecto, Malagón (2008) afirma:

A diferencia de los artistas que trabajaban en los años sesenta y que buscaban representar atrocidades físicas y psicológicas, estos artistas (los de los años ochenta y noventa) optaron por presentar escenas, procesos y objetos que, en lugar de representar, presentan imágenes complejas de indiferencia, olvido y sufrimiento. Los artistas previos querían denunciar realidades relacionadas con un conflicto que había sido poco visible en las áreas urbanas. Ellos aspiraban a impactar a los espectadores para que adquirieran conciencia sobre el carácter monstruoso de los acontecimientos. Los más recientes buscaron centrarse selectivamente en efectos e implicaciones de acciones que con frecuencia pasan desapercibidos, debido a una superabundancia de imágenes e información. De tal manera que, en lugar de impactar a los espectadores, buscan generar preguntas en éstos. Los medios utilizados por ellos a partir de mediados de 1980 contribuyen a este propósito. (p. 27) 
Así, para Malagón (2008), estas formas de expresividad se desplazan de una condición "neofigurativa", presente en los artistas de las décadas de los años sesenta y parte de los setenta, a la emergencia de un lenguaje visual indéxico como rasgo predominante en algunos creadores de las décadas de los ochenta y noventa. Es decir, mientras los primeros buscaban dar cuanta de un estado de cosas, situaciones y acontecimientos, con el fin de hacer visible, describir críticamente e incluso denunciar los hechos y las acciones violentas que atravesaban la sociedad, los segundos proyectaron la mirada hacia la reunión de indicios, huellas y detalles que parecían pasar desapercibidos en la intensa circulación de hechos y violencias en las representaciones sociales y en los medios de comunicación.

Ahora bien, la primera década del siglo XXI, trae consigo una etapa distinta del conflicto armado. En este periodo de tiempo fracasa un nuevo intento de negociación de paz entre el gobierno de Andrés Pastrana (1998-2002) y las Fuerzas Armadas Revolucionarias de Colombia, FARCEP. Paradójicamente, unos años después, en el primer gobierno de Álvaro Uribe Vélez, se concreta la implementación de los Acuerdos de Santa Fé de Ralito. Tales acuerdos tuvieron como principal resultado la cuestionada desmovilización de algunas estructuras paramilitares y la extradición de sus principales cabecillas a Estados Unidos, con el fin de que pagaran en ese país condenas de ocho años de prisión, en promedio, por delitos relacionados con el narcotráfico, sin contemplar delitos de lesa humanidad, ni relacionados con la vulneración a la sociedad civil. En este periodo de gobierno se incrementan la confrontación militar y las medidas represivas.

1. Hacemos referencia aquí a los diálogos de paz entre las Fuerzas Armadas Revolucionarias de Colombia (FARC- EP) y el Gobierno Nacional, liderado por el entonces presidente Andrés Pastrana. Este proceso de negociación se llevó a cabo entre 1998 y 2002. Algunas de las particularidades de este proceso tuvieron que ver con el acuerdo de desmilitarizar una zona geográfica, cuya extensión era de 140 mil kilómetros, correspondiente a cinco municipios del Meta y Caquetá. La zona de "distensión" o de "despeje", como fue conocida en su momento, inició el 7 de noviembre de 1998. En esta zona geográfica se concentraron todos los integrantes de las FARC y era el escenario de encuentro de la Mesa de Negociación entre los delegados del gobierno, el grupo guerrillero y los delegados internacionales. Sin embargo, estos diálogos no tuvieron buen final y terminaron rompiéndose por decisión unilateral del gobierno en 2002
En este contexto se da la implementación de la Ley 795 de 2005, conocida como la Ley de Justicia y Paz². Para la implementación de esta Ley, se crea la Comisión Nacional de Reparación y Reconciliación (CNRR)³, que después daría lugar al Centro Nacional de Memoria Histórica (CNMH) y al Grupo de Memoria Histórica4.

La referencia anterior resulta relevante para los intereses de esta reflexión, toda vez que la creación de este organismo, sumado al trabajo de sectores académicos y sociales, permitió el surgimiento de una serie de informes investigativos sobre casos y hechos relacionados con el conflicto armado interno y la violencia política, en los cuales el énfasis no solo se concentraba en la confrontación bélica entre las fuerzas armadas oficiales, los grupos paramilitares y la insurgencia, sino en los efectos de la violencia y en los daños ocasionados a las víctimas, sus entornos colectivos y sus territorios.

Esta mirada permitió que, por primera vez en casi toda la historia del conflicto armado interno, los testimonios de las víctimas y sobrevivientes tuvieran un espacio de reconocimiento, tanto en procesos de carácter ju-

2. Este marco normativo fue creado en el primer gobierno de Álvaro Uribe Vélez (2002 2006) y tenía como principal objetivo facilitar la desmovilización de los grupos paramilitares. Si bien el texto de la ley cobijaba también a combatientes de grupos guerrilleros, la Ley de Justicia y Paz fue creada en el contexto de negociación entre el gobierno y una parte importante de las estructuras paramilitares, lo cual derivó en la supuesta desmovilización de más de 30.000 actores armados y la extradición a Estados Unidos de los principales cabecillas de estas estructuras, por el delito de narcotráfico.

3. La Comisión Nacional de Reparación y Reconciliación fue un organismo creado por el gobierno de Uribe Vélez, en el contexto de la Ley de Justicia y Paz, con el fin de llevar a cabo tres funciones específicas: 1. garantizar la participación de las víctimas en los procesos de esclarecimiento judicial; 2 . presentar un informe sobre el origen y evolución de los grupos armados ilegales; y 3 . hacer un seguimiento a los procesos de desmovilización. La Comisión alcanzó a publicar tres informes de casos emblemáticos, correspondientes a las masacres de Trujillo, El Salado y Bojayá.

4. Este grupo fue creado por la Ley de Víctimas y Restitución de Tierras 1448 de 2011 y fue el organismo que reemplazó a la Comisión Nacional de Reparación y Reconciliación. Su labor fundamental ha sido contribuir a la construcción de memoria por parte del Estado, frente a las violaciones y efectos de la violencia política en los territorios y poblaciones nacionales. De la misma, tiene como tarea contribuir al esclarecimiento de la verdad y apoyar la implementación de las políticas de reparación integral de las víctimas. 
dicial, como en la tarea de narrar los efectos y las consecuencias de la violencia, tanto desde el acompañamiento de iniciativas académicas, como desde su registro en crónicas periodísticas, producciones culturales, entre otros.

En el caso de las prácticas artísticas, este cambio de perspectiva se refleja en el surgimiento de una serie de trabajos creativos que tomaron distancia del lenguaje pictórico como medio tradicional de representación, para dar a lugar a formas de expresión que asumieron soportes como el video, la fotografía, la instalación, el performance, todo lo cual muestra no solo la emergencia de lenguajes y técnicas inscritas en las lógicas de lo que reconocemos como prácticas artísticas contemporáneas, sino también el surgimiento de otras miradas y perspectivas sobre la violencia política. En este renovado registro, se hace visible un cambio de posicionamiento de los artistas frente a la realidad política, en la medida en que buscan aproximarse a los efectos, los testimonios y las experiencias derivadas de la violencia política en grupos sociales y territorios concretos.

Estos tránsitos expresivos se relacionan en un contexto más amplio con una resignificación de los vínculos entre arte y política desde finales del siglo XX, según lo señalado por autores como Jacques Rancière, quien en El malestar de la estética plantea que desde hace unas décadas asistimos al fin o a la crisis definitiva de la "utopía estética”, es decir, la puesta en cuestión de "la idea de una radicalidad del arte y de su capacidad de contribuir a una transformación absoluta de las condiciones de existencia colectiva” (Rancière, 2011, p.27).

De este panorama post-utópico de las prácticas artísticas, se derivan, según Rancière, dos configuraciones expresivas que caracterizan los vínculos y nuevas tensiones entre el arte y la política. En primer lugar, la emergencia de unas prácticas del arte que, sin negarse la posibilidad de configurar una mirada crítica frente a las relaciones y formas de ser colectivas, se distancian de los lenguajes comprometidos con las ideologías políticas que tuvieron auge en los años 60 y 70 . En este caso la radicalidad de estas prácticas se mantiene en sus formas de expresión y en la intencionalidad de proponer lecturas heterogéneas o incluso yuxtapuestas sobre la experiencia del mundo, a través de una actualización de su potencia expresiva. Así lo advierte Rancière (2011): "Esta potencia es con frecuencia pensada bajo el concepto kantiano de lo "sublime" como presencia heterogénea e irreductible en el corazón de lo sensible de una fuerza que lo desborda” (p. 28). En segundo lugar, unas prácticas relacionales que se distancian de las pretensiones de transformación de las condiciones de vida por medio del arte, pero que insisten en comprender las prácticas artísticas como formas de intersticio social.

En el sentido desarrollado por Nicolas Bourriaud (2008), si bien las prácticas del arte no pueden transformar de forma completa los aspectos conflictivos de una sociedad, sí están en capacidad de abrir un espacio y un tiempo propio, desde el cual es posible abstraer y tematizar aspectos de interés colectivo. Este ámbito relacional permite al artista operar recortes de realidad en los que se hace posible abrir un espacio de discusión, de diálogo o como mínimo de reflexión, propicio para reconfigurar o repensar rasgos de las interacciones colectivas.

En la primera conformación, que denominaremos aquí como "actualización de lo sublime”, Rancière propone, a su vez, dos consideraciones expresivas: por una parte, las prácticas artísticas que intentan instalar "un ser en común anterior a toda forma política particular” (2011, p. 28), es decir, prácticas artísticas que suscitan formas de cohesión concretas a través de la detonación de sentido de una imagen o referente común y su intensificación expresiva. De otra parte, las prácticas artísticas que asumen la función de "testimoniar la existencia de lo no presentable", es decir, que asumen como eje central de expresividad la "separación irreductible entre la idea y lo sensible” (p. 29). Por ende, el tipo de posibilidad de cohesión que suscitan las prácticas artísticas, no está construida sobre la sedimentación de una promesa de transformación política, ni siquiera en un sentido estricto a través de la denuncia, sino por el contrario, en la conformación de una instancia en la que el colectivo se reconoce desde un reflejo negativo, en el que es posible desplegar una visión crítica de la realidad compartida.

En la segunda vía, Rancière advierte la referencia a prácticas del arte que proyectan sobre una condición relacional, la posibilidad de problematizar situaciones y contextos microsociales, no con el fin de transformar su 
conformación, sino de crear o recrear lazos y puntos de conexión, a través de las interacciones colectivas. Al respecto advierte Rancière (2011):

La estética relacional rechaza las pretensiones de autosuficiencia del arte al igual que los sueños de transformación de la vida a través del arte, pero reafirma sin embargo una idea esencial: el arte consiste en construir espacios y relaciones para reconfigurar material y simbólicamente el territorio de lo común. (p. 30)

En esta perspectiva, se hace visible una tematización de situaciones y contextos, los cuales hacen parte de la conformación de realidad compartida, con miras a reconocer en la práctica artística un medio o un espacio para su problematización. En el contexto de las prácticas artísticas que tematizan aspectos relacionados con la violencia política en Colombia, tomamos como casos de análisis los procesos creativos de los artistas Juan Manuel Echavarría, Erika Diettes y el colectivo "Magdalenas por el Cauca”, conformado por Yorlady Ruiz y Gabriel Posada.

En lo que sigue de la reflexión nos proponemos dos cosas: lo primero es situar la forma como en los proyectos creativos mencionados se expresan, entre otros rasgos, un sentido renovado de la relación entre arte y política, unas formas de interacción de los artistas con contextos geográficos y grupos de sobrevivientes y familiares de víctimas, y una ampliación del sentido de lo testimonial, como ámbito no limitado a la reconstrucción oral o escrita de las experiencias relacionadas con el conflicto armado. Lo segundo es presentar aspectos generales de la trayectoria y el sentido que cada uno de los artistas busca darle a su trabajo creativo. En este segundo momento proponemos un ejercicio reflexivo que intenta hacer visibles algunos rasgos de proximidad y contraste entre los proyectos creativos de los artistas trabajados, desarrollando rutas interpretativas alrededor de las formas de mediaciones que posibilitan sus trabajos artísticos.

\section{El arte frente a la violencia: \\ Poéticas, políticas y formas de interacción}

\section{Desenterrar y hablar}

Juan Manuel Echavarría ocupa un lugar importante en el contexto del arte contemporáneo en Colombia. Su trabajo creativo ha sido expuesto en lugares emblemáticos para las artes visuales a nivel nacional e internacional, como el Museo de Arte Moderno de Bogotá, el Museo de Antioquia, el Centro Cultural Rogelio Salmona de la Universidad de Caldas, el Museo de Arte Moderno de Nueva York, entre otros. Sumado a esto, su trabajo ha tenido una especial presencia en espacios de reflexión académica sobre la violencia política e iniciativas de memoria histórica, aportando pistas para entender la relación entre arte y política. También a través de la Fundación Puntos de Encuentro, ha acompañado la realización de proyectos que articulan asociaciones de víctimas y sobrevivientes, como el caso de las Tejedoras de Mampuján en Montes de María y actores desmovilizados de la guerrilla, el paramilitarismo y fuerzas del Estado, a través del proyecto La Guerra que no hemos visto, llevado a cabo en distintos lugares del territorio nacional. El interés por estas problemáticas, sumado a una amplia trayectoria investigativa y de producción creativa, ha contribuido a que desde sectores, tanto académicos como artísticos, se reconozca y vincule el trabajo de Echavarría con iniciativas de construcción de memoria histórica, lo cual coincide, en buena medida, con la percepción del artista sobre su propio quehacer:

A mí no me interesan las cuatro paredes del estudio. Me interesa romperlas e ir allá afuera. Creo que hay un tipo de artista que trabaja en su burbuja y es absolutamente válido; entonces lee en el periódico la historia de dolor y entra en relación con ella, pero permanecen muy blindados en su estudio: blindados y protegidos. (...) a mí sí me interesa ir a esa geografía de la guerra porque esa memoria nos queda. Yo soy un artista que le interesa la memoria y esta es la que escucho y veo en carne viva. (Echavarría, comunicación personal, 2 de julio de 2015) 
Ahora bien, la intención de aportar a la construcción de memoria sobre el conflicto y la violencia desde las prácticas artísticas implica, de entrada, transitar una serie de tensiones, pues la construcción de memoria histórica es también un escenario de debate político en el que distintas versiones del pasado entran a medir su capacidad para resolver los puntos ciegos de los acontecimientos y a tratar de construir sobre estas versiones formas expresivas y narrativas que permitan su transmisión cultural.

Lo anterior compromete, de hecho, un posicionamiento del artista, no necesariamente en un sentido ideológico, sino en el de inscribir su lugar de enunciación, de hacer visible su perspectiva, su forma particular de proyectar su práctica artística en el contexto de la violencia política. Al respecto expresa Echavarría:

Yo no veo el arte para denunciar, ni para decir los paramilitares, los guerrilleros o el ejército colombiano fueron los culpables. Eso que lo hagan los jueces y los fiscales; no veo el rol del artista para denunciar eso (...) Yo no señalo, yo estoy es visibilizando. Mi trabajo es visibilizar, no estetizar ¿Cómo va uno a estetizar la guerra? Uno la visibiliza. Ese es mi acto, esa es mi acción, visibilizar. (Echavarría, comunicación personal, 2 de julio de 2015)

Así, frente a los constantes señalamientos y justificaciones de los actos de violencia, frente a la circulación mediática de imágenes e información que acostumbra la mirada y naturaliza las formas de violencia, los proyectos artísticos de Echavarría se configuran en dispositivos de visibilidad que provocan variaciones en los registros de la realidad, en la velocidad de las informaciones y en las formas de dar cuenta de los acontecimientos, en un sentido, valga decir, similar a lo señalado por Nelly Richard (2007), esto es, como finalidad del arte crítico:

El arte crítico necesita interrumpir, aunque sea por un momento, la velocidad de este flujo mediático, para que la festividad de lo desechable que cultiva el mercado no haga desaparecer para siempre la fantasmática de la desaparición que nace del duelo irresuelto de una memoria faltante todavía en suspenso. El arte crítico debe cambiar la velocidad de la exposición y la circulación de las imágenes para que la dispersión en el espacio se vuelva concentración en el tiempo, adentrándose en los recovecos que protegen el residuo opaco de la memoria de las obs- cenas consignas de visibilidad total de las exhibiciones de pantallas y vitrinas, para hacerse cargo de 'la mediación trunca, fallida, suspendida, de lo que no admite lo visual, de lo que no soporta visión. De lo que no llega a escena ni a imagen'. (p. 88)

Desde esta perspectiva, el lugar de lo político en el arte no tendría que ver necesariamente con la denuncia, con una función documental o, incluso, con una forma de sanar o remediar el daño ocasionado por la experiencia de la violencia política, sino más bien, con la continua posibilidad de constituirse como una presencia inquietante, como una forma de aludir a otros sentidos de la experiencia de la violencia. La práctica artística opera, en este caso, como mediación frente a aspectos problemáticos de esta realidad; abre un espacio, un intersticio en el que es posible repensar los efectos de la guerra. Echavarría lo sintetiza así:

Hay un camino que es la reportería gráfica, que es muy importante, pero ese no es el camino que yo escogí. Yo escogí una mirada poética, es lo que a mí me interesó, cómo lograr poesía en mi imagen y en mis proyectos. Mi obra tiene que tener el elemento poético, porque yo creo que para hablar de la tragedia a través del arte, tiene que ser con poesía y con mucho respeto hacia quienes han sufrido el dolor. (Echavarría, comunicación personal, 12 de abril de 2016)

En este marco de referencia tiene lugar un replanteamiento del valor político en las prácticas artísticas, expresado en ópticas como las de Mieke Bal (2010), teórica de los estudios visuales. Según Bal, el arte que se supone y se reclama a sí mismo como político y que "se manifiesta en lugar de realizar, que declara en lugar de actuar, que decreta en lugar de hacer un esfuerzo", y que termina reduciéndose a un juicio moralizante o de simple señalamiento a lo que considera como dominante “-ideología, clase, institución, pueblo- termina proclamando su propia inocencia” (p. 40).

Desde esta mirada, podríamos decir que si bien los proyectos creativos de Echavarría, Diettes y el colectivo “Magdalenas por el Cauca”, no pueden eludir las tensiones y posicionamientos ideológicos y partidarios que se tejen alrededor de los hechos y sus interpretaciones, estas prácticas artísticas pretenden que tales posturas no terminen por ahogar su capacidad expresiva y su forma particular de reflexionar y hacer visibles aspectos en- 
tramados en las complejas dinámicas de los discursos, las justificaciones y señalamientos que se construyen alrededor de los acontecimientos y de las apuestas de construcción de memoria colectiva.

Reconocer el dolor de los demás

Erika Diettes se ha ocupado, desde hace más de una década, de trabajar con sistematicidad los efectos de la violencia política en Colombia. Desde la fotografía y la instalación, su trabajo artístico aborda aspectos relacionados con la desaparición forzada y los duelos no resueltos. Además de su formación académica como artista visual, Diettes ha realizado estudios académicos en los campos de la Comunicación Social y la Antropología, lo cual representa una clave importante en la comprensión de su proceso creativo, en la medida en que sus trabajos tienen como componente central una cuidadosa labor de campo que, al igual que en el caso de Echavarría, ha implicado el recorrido por distintas zonas geográficas del país, el levantamiento de un archivo visual y audiovisual, integrado por registros de lugares, testimonios de sobrevivientes y familiares de víctimas.

En consecuencia, además de una resignificación del lugar político de las prácticas artísticas, a la cual aludíamos también en el trabajo creativo de Juan Manuel Echavarría, los proyectos artísticos de Erika Diettes proponen, también, reflexionar sobre las formas de apropiación de perspectivas, metodologías y procedimientos propios de las ciencias sociales, tales como las inmersiones en espacios geográficos, la interacción con grupos sociales, la observación participante, el uso de la entrevista, la reconstrucción de testimonios y el seguimiento a trayectorias de vida, como parte de una práctica creativa transdisciplinar y reflexiva.

Si bien la relación entre arte y etnografía, o para ser más precisos, entre prácticas artísticas y métodos de las ciencias sociales no es nueva en el arte contemporáneo, en el caso del trabajo de Erika Diettes, entrar en relación con los familiares de desaparecidos no solo implica un medio para acceder a la imagen fotográfica o al objeto que posteriormente será el eje central de su trabajo artístico, sino también la posibilidad de propiciar un espacio de diálogo, de escucha y recepción de los testimonios y las experiencias. Aunque tales testimonios no aparecen de forma directa en las imágenes de ninguno de los trabajos de Diettes, resultan ser parte constitutiva de la experiencia previa a la realización de la obra y representan la primera forma de activar la participación de los familiares de las víctimas en la construcción del proyecto creativo.

Esta interacción problematiza a su vez los roles tradicionales del artista contemporáneo, sus formas de interactuar con realidades y grupos sociales específicos. En este sentido, Hall Foster propone, en El retorno de lo real (2001), desde la figura del artista como etnógrafo, algunas claves interpretativas que resultan relevantes en el marco de esta reflexión. Para Foster, la relación entre arte y etnografía ha estado signada desde finales del siglo XX por una serie de usurpaciones disciplinares. El etnógrafo parece "usurpar" la capacidad del artista para resolver formal y expresivamente la interpretación de aspectos entramados en las complejidades culturales y políticas de los grupos humanos y traducirlas en imágenes, objetos, proyectos narrativos que no solo ilustran una conformación de realidad concreta, sino que aportan a su problematización y comprensión.

Por otro lado, los artistas, "usurpan" la capacidad del etnógrafo de proyectar trabajos de campo, en los que, a partir de la puesta en marcha de técnicas de investigación como la entrevista, las historias de vida y de recursos como la observación, la interacción directa y generación de empatía, logran acceder a lo específico de experiencias y testimonios, construyendo rutas comprensivas más seguras, en las que la reflexividad y la acción entran en diálogo (Foster, 2001). En este sentido, sobre su propio trabajo, enuncia Diettes:

Yo siempre digo que a mí la antropología me enseñó a preguntar. Tal vez el camino de conocer las historias, de recorrer, viene también de esa necesidad de descubrir a partir del testimonio, de que la gente me empezó a creer. Es el camino que decidí recorrer, es mi forma de implicarme y es mi forma de trabajar. Se puede llegar por otro camino, pero este es el que me permite crear (Diettes, comunicación personal, 13 de abril de 2016) 
Ahora bien, las prácticas artísticas resultan demasiado limitadas en la posibilidad de ofrecer soluciones a problemáticas enmarcadas en las consecuencias de la violencia política; por otro lado, tampoco buscan ni pretenden la generación de conocimiento de carácter académico sobre estos fenómenos y realidades; por lo tanto, si los artistas no se aproximan a las geografías de la guerra, a los testimonios y las experiencias de los sobrevivientes, con el fin de transformar sus condiciones colectivas, de aportar, en alguna medida a la superación de las consecuencias de la violencia por vía de la capacidad expresiva del arte, sería válido preguntarse por el sentido de estas prácticas y procesos creativos.

Así, las prácticas artísticas contemporáneas configuran no solo la adecuación de recursos técnicos y expresivos que dan forma a una obra de creación. El arte se proyecta, en este caso, como un dispositivo de transmisión cultural que articula en su interacción con el mundo, formas particulares de valorar e interpretar la realidad. Las creaciones artísticas, en tanto conformaciones culturales, constituyen formas de mediación, que al modo de una interfaz, permiten crear o afianzar vínculos y conexiones entre los grupos sociales y sus realidades, valiéndose de los lenguajes y los procesos expresivos que les son propios.

Tal mediación, en el caso del trabajo de Diettes, se proyecta en un primer momento, en la interacción con los familiares de las víctimas, en el momento de activar el testimonio, de hacer visibles los objetos que permiten el tejido del relato. Al respecto advierte la artista:

Ofrecerse de escucha, implica que tienes que ganar unas herramientas distintas. Lo que prima no es tu voluntad ni tu interés. No parto de la intención de redimir el dolor de las víctimas a través del arte, no, no es desde ahí que yo procedo. Por ejemplo, yo no llamaría mi obra un trabajo colectivo porque yo estoy tomando las decisiones de las imágenes finales, de lo que estoy haciendo. Pero el hecho de que los objetos los escogen las personas, la tarea es para mí resolver eso en su composición, con todos los elementos que tengo, los que me faltan, los que debo conseguir. Entonces soy yo la que tiene que ajustarse, resolver para contarlo desde la postura que quiero tomar. En mi caso, la postura es en torno a la belleza y a la dignidad de los dolientes. (Diettes, comunicación personal, 13 de abril de 2016)
Si bien Diettes parte de una idea inicial de proyecto creativo, las posibilidades de realización dependen de la apertura de ese espacio de interacción y diálogo, en el que se activan los relatos y los testimonios que otorgan el sentido y las posibilidades expresivas al proceso de creación. Así los testimonios no aparezcan de forma literal en la imagen, resultan ser el puente, la posibilidad de conectar las experiencias vividas de la violencia y la práctica artística.

En este último punto, tiene lugar un segundo momento de la mediación, en el cual se produce la traducción del testimonio, del relato inicial sobre el objeto elegido por cada doliente, que da lugar a la configuración del proyecto creativo, es decir, el momento en el que se proyecta la construcción de la imagen o el objeto artístico. Dice Diettes:

Trabajar desde el doliente, transformando el recuerdo en una imagen bella, tiene un sentido. Creo en el poder sanador, no del arte; no es que por hacer un cuadro bello el horror de la violencia se sane o se cure, no, porque de entrada esto no tiene cura, no hay cómo sanarlo, no hay cómo repararlo. Pero hay algo en el ejercicio de atreverse a recordar desde la vida, de ponerse a buscar no en el hecho violento sino en la vida. Ahí es donde se abre un poco la posibilidad de construirte y de volverte a pegar tú mismo con la ausencia. Porque finalmente, a partir de ahora, todo es la ausencia. (Diettes, comunicación personal, 13 de abril de 2016)

De este modo, las formas de mediación que se proyectan en el trabajo creativo de Erika Diettes, Juan Manuel Echavarría y, como lo veremos más adelante, del colectivo "Magdalenas por el Cauca", cada uno con sus particularidades, implican la posibilidad de agenciar aproximaciones a la devastación causada por la violencia y a los efectos de la guerra desde formas expresivas, metáforas, elementos simbólicos, configuraciones poéticas que permiten la emergencia de sentido en medio de lo insalvable. 


\section{El río como testigo silencioso}

El proyecto creativo Magdalenas por el Cauca, liderado por los artistas Yorlady Ruiz y Gabriel Posada, cuenta con un poco más de diez años de procesos,, consolidándose como uno de los referentes artísticos de mayor relevancia en el contexto del eje cafetero y el Valle del Cauca, en relación con los fenómenos de la violencia política y la desaparición forzada.

La ribera del río Cauca, entre los departamentos de Risaralda y Valle del Cauca, representa para las comunidades y grupos sociales que la habitan, la fortuna de tener a disposición uno de los principales afluentes hídricos del país, relevante como medio de transporte, comunicación y sustento. Sin embargo, este mismo río también ha sido testigo silencioso de años de barbarie y violencia; su caudal ha cobijado y arrastrado centenares de cuerpos, residuos y ruinas derivadas de las dinámicas de los grupos armados localizados en las distintas zonas geográficas atravesadas por su recorrido. En la actualidad está en riesgo de desaparecer, debido a las consecuencias del cambio climático y a las constantes alteraciones de su caudal por la incursión de proyectos de infraestructura energética.

Como proyecto artístico, Magdalenas por el Cauca surge en el contexto de una residencia artística, otorgada a Gabriel Posada por el Ministerio de Cultura en 2008. En un sentido similar a los procesos creativos de Echavarría y Diettes, uno de sus ejes centrales de la propuesta fue la construcción de un vínculo de largo aliento con el territorio, la geografía y las dinámicas colectivas que configuran el modo de ser de los grupos sociales que habitan las zonas ribereñas del río. De acuerdo con Yorlady Ruiz:

La obra -inicia- a través de los recorridos, entre agosto y octubre de 2008, caminando aproximadamente 70 kilómetros desde la vereda Beltrán, en el municipio de Marsella (Risaralda), hasta la vereda Cauca, en Cartago (Valle del Cauca), escuchando y rayando una cartografía constante de hallazgos simbólicos, relatos míticos y fantasmales franqueados humildemente por sus habitantes en medio de meandros, olvidos y naufragios, conspirados por la crueldad del hombre. Estos diálogos fueron el detonante para encontrar la textura, los soportes y el imaginario que se imprimió en la obra. Hablando con la gente se valora su memoria, se reflexiona sobre la percepción de la vida y la muerte. Se promueve la palabra y el diálogo; se exorciza el llanto, se dignifica la vida. (Ruiz, comunicación personal, febrero 27 de 2019)

El valor asignado al diálogo, a la proximidad, a la palabra de los sobrevivientes y familiares de víctimas cobra especial sentido en este proyecto; sin embargo, el valor de lo testimonial no necesariamente está asignado a la literalidad de las palabras o a la reconstrucción objetiva de experiencias ligadas a la violencia, sino a su capacidad de activar otros aspectos expresivos de tal experiencia, que enmarcan el insumo de la mediación de prácticas artísticas. Dice Ruiz:

Similar a ello sucede cuando las personas cuentan lo propio, "lo que a mí me pasó”. Se reactiva la memoria y dan cuenta de la historia de una manera muy distinta. Hay textura, color, sentimientos, recuerdos, afectos, hay una casa, un pueblo, un barrio, sonidos, música, nace en uno una nación desconocida y los seres silenciados se levantan y los ves que atraviesan el pasillo y te miran a los ojos. El testimonio da vida a esos episodios que, en general, por el paso de los años, se van borrando. El testimonio vuelve y ubica todo o reubica todo, capa por capa reconstruye la casa y la desarma. (Ruiz, comunicación personal, febrero 27 de 2019)

Sin embargo, el lugar asignado tradicionalmente a los testimonios de los sobrevivientes en contextos de violencia política suele estar relacionado con su valor en la reconstrucción, por medio de relatos orales o escritos, de narraciones que puedan esclarecer $\mathrm{u}$ ofrecer rutas comprensivas sobre hechos asociados con las dinámicas del conflicto, los cuales, posteriormente, pueden resultar relevantes en las inculpaciones judiciales o servir de soporte a hipótesis académicas o como parte fundamental de la operatividad de la justicia transicional y los procesos de memoria histórica.

Lo anterior se problematiza a partir de planteamientos como los de Giorgio Agamben (2009), quien sugiere que el testimonio, en el contexto de hechos de violencia, lleva en sí mismo los signos de su propia limitación. Advierte Agamben:

El testigo testimonia de ordinario a favor de la verdad y de la justicia, que son las que prestan a sus palabras consistencia y plenitud. Pero en 
este caso el testimonio vale en lo esencial por lo que falta en él; contiene, en su centro mismo, algo que es intestimoniable, que destruye la autoridad de los supervivientes. Los "verdaderos" testigos, los “testigos integrales" son los que no han testimoniado ni hubieran podido hacer-

lo. (p. 34)

De este modo, Agamben refiere que en la mayoría de los casos, quienes podrían ofrecer el relato más ajustado a la forma como se dieron los hechos de violencia, son precisamente los que no pueden testimoniar, es decir, los asesinados, los desaparecidos o quienes han sido silenciados a la fuerza. Por otro lado, la reducción del testimonio a su reconstrucción en la forma de la palabra, de la oralidad o de la escritura, como supuesta constatación de objetividad, representa una forma limitada de acceder a la experiencia de la violencia o en general a cualquier experiencia humana.

Para Agamben, el testimonio intenta hacer inteligible algo que como totalidad no puede contener, pues más que ser el de la "verdad" de un hecho o acontecimiento, su condición lo aproxima a lo que podría ser una suerte de traducción. Desde este punto de vista, su lugar se configura entre "lo dicho y lo no dicho" (Agamben, 2009) y por tanto, su relación con la verdad queda en su interior puesta en crisis o por lo menos determinada por su opacidad. La verdad sobre el pasado o sobre cualquier experiencia vivida, solo alcanza a configurarse en el testimonio, como una manifestación espectral.

Las prácticas artísticas que tomamos aquí como referencia, se instalan en este ámbito de opacidad del testimonio, no con el fin de escudriñar o evaluar su objetividad ante los hechos que remiten, sino para agenciar otras mediaciones que den lugar a formas expresivas de reconocer y exteriorizar algunas de las implicaciones de la experiencia de la guerra y la violencia política.
Testigos, indicios y ritualidades.

Mediaciones del arte sobre la violencia política en Colombia

Los relatos y testimonios de los sobrevivientes y familiares de víctima; las prácticas culturales y de carácter conmemorativo que la violencia genera como efecto al interior de las comunidades; las formas de mediación y prácticas de duelo y dignificación del dolor que tienen lugar en contextos que han afrontado experiencias relacionadas con la violencia política; la referencia a las huellas, las ruinas y los residuos que se derivan de los hechos de violencia y que se inscriben en los espacios geográficos como claves de comprensión y mediación con el pasado reciente y, por ende, como proceso central para la construcción de memoria, configuran puntos comunes en los trabajos creativos de Juan Manuel Echavarría, Erika Diettes y el colectivo "Magdalenas por el Cauca". Sin embargo, en cada proyecto, tales aspectos son abordados de un modo singular. En lo que sigue de esta reflexión proponemos un diálogo entre algunos de los trabajos artísticos de estos artistas, con el fin de reflexionar y contrastar algunas de sus implicaciones estéticas, sociales y simbólicas. Para ello, proponemos tres momentos en los que buscamos explorar con más detalle estos escenarios de sentido: Rostro y testimonio; Ritualidades a la orilla del río; y Ruinas, indicios y rastros de humanidad.

\section{Rostro y testimonio}

La referencia a la condición existencial de ser testigo de la violencia y del acto de testimoniar como construcción narrativa, es abordada en el trabajo titulado Bocas de Ceniza, realizado por Juan Manuel Echavarría en 2004. La pieza audiovisual, cuya duración es de un poco más de 18 minutos, contiene ocho testimonios expresados en cantos que son interpretados por testigos-sobrevivientes de acontecimientos violentos que tuvieron lugar en distintas zonas geográficas del país. Los cantos recrean episodios como 


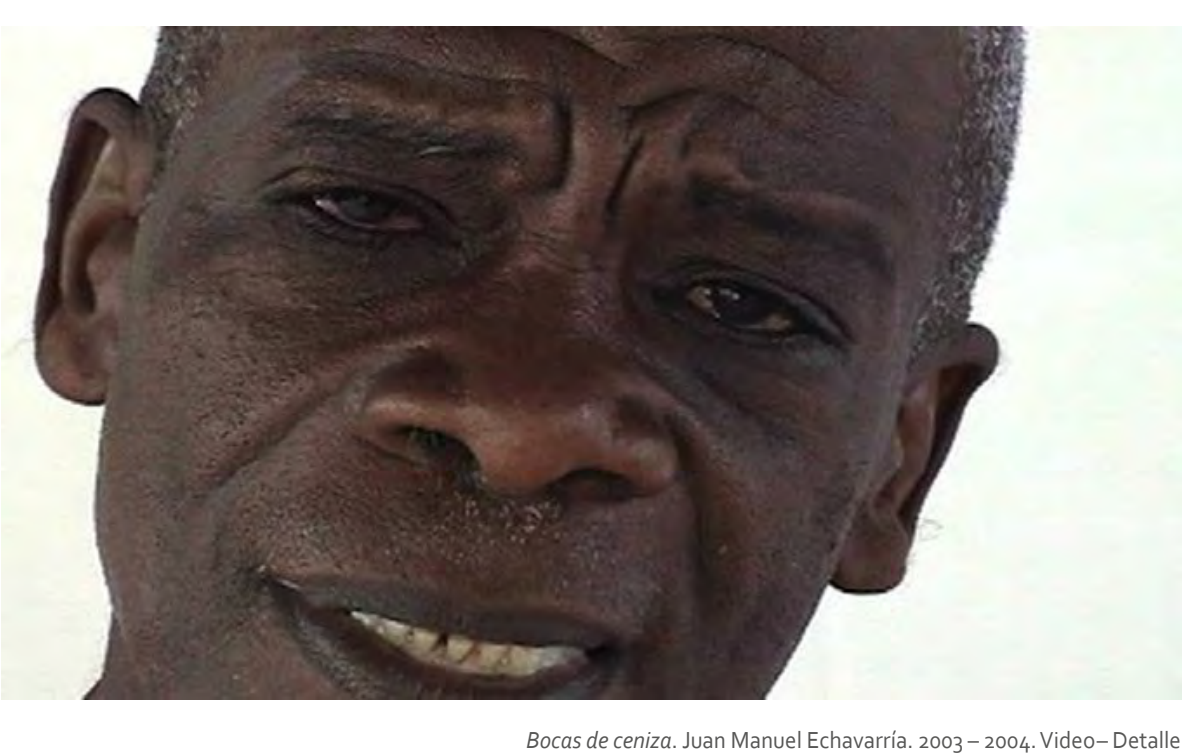

los desplazamientos masivos ocurridos en el bajo Atrato entre 2000 y 2002, la masacre de El Salado y Bojayá, ocurridas entre el 16 y el 19 de febrero del 2000 , y el 2 de mayo de 2002, respectivamente ${ }^{5}$.

Los testimonios se inscriben en ritmos, cosmovisiones, creencias propias de los contextos geográficos en los cuales se originan, como una forma de constatar que más que constituirse de datos y hechos objetivos, remiten a formas particulares del recuerdo, al tiempo que contienen su propia gramática. Es decir, que el testimonio se construye siempre desde un posicionamiento subjetivo que no solo hace referencia a hechos, sino a todo un entorno que compromete modos particulares de ser y habitar el mundo.

El artista, en este caso, registra las gestualidades, propicia un espacio, elige un plano secuencia y reúne en el formato del video las narraciones, sin intervenir en el sentido y en la manera como cada canto relata la experiencia de la violencia. Propone una perspectiva que implica la decisión

5. El audiovisual completo se puede ver en el siguiente enlace: https://jmechavarria.com/ es/work/bocas-de-ceniza/ de registrar los rostros en primer plano, separar por transiciones sencillas cada testimonio, manteniendo sus matices y particularidades.

¿Qué les imprime a estos testimonios el hecho de hacerse canto? En este caso, cantar permite transitar de la palabra del testimonio a la acción performativa, es decir, a un campo de enunciación que involucra tanto el contenido semántico de las palabras como la relación tejida con la gestualidad y la piel, con el cuerpo y el entorno, con el ritmo y las formas de autoafirmación en un espacio y un tiempo concretos. Al respecto, relata Echavarría:

En Bocas de ceniza ya está la guerra, pero al transformar su dolor en un canto, también eso es una transformación dentro del arte. El arte en este caso es un medio y el artista un mediador, en este caso, reconociendo que ellos tenían una obra que había que visibilizar y que la podemos ver sin caer en la barbarie. Porque yo creo que esos cantos son una mirada oblicua a la barbarie. No es la mirada directa, es una mirada indirecta, para no petrificarse. Y entendí algo importante con Bocas de ceniza y es que las emociones son importantes para el espectador; me interesa abrir esos espacios y tocarle a la gente el corazón. (Echavarría, comunicación personal, 12 de abril de 2016)

De este modo, hacer visible esta condición del testimoniante a través de sus propias formas de expresión cultural, permite también la emergencia de lo performativo, provoca una suerte de repolitización de la voz y del papel histórico de los sobrevivientes, no en el sentido de procurar nichos ideológicos para sus demandas, sino como posibilidad de una localización cultural y territorializada de la violencia en tanto experiencia vivida, inscribiendo el relato sin que pase por la profilaxis de la edición del informe de investigación académico o del expediente judicial, sino justamente en el acento, en el tono, en la gestualidad y el ritmo del cuerpo que presencia y ofrece testimonio. Esta es, cómo dudarlo, una forma de constatar que hay diversas maneras de nombrar, decir y relacionarse con la violencia y que, como advierte Veena Das (2008), tales diferencias no están dadas solo en el plano semántico sino que “-reflejan el punto en que el cuerpo del lenguaje resulta indiferenciable del cuerpo del mundo- el acto de nombrar constituye una expresión performativa” (Das, 2008, p. 146). 


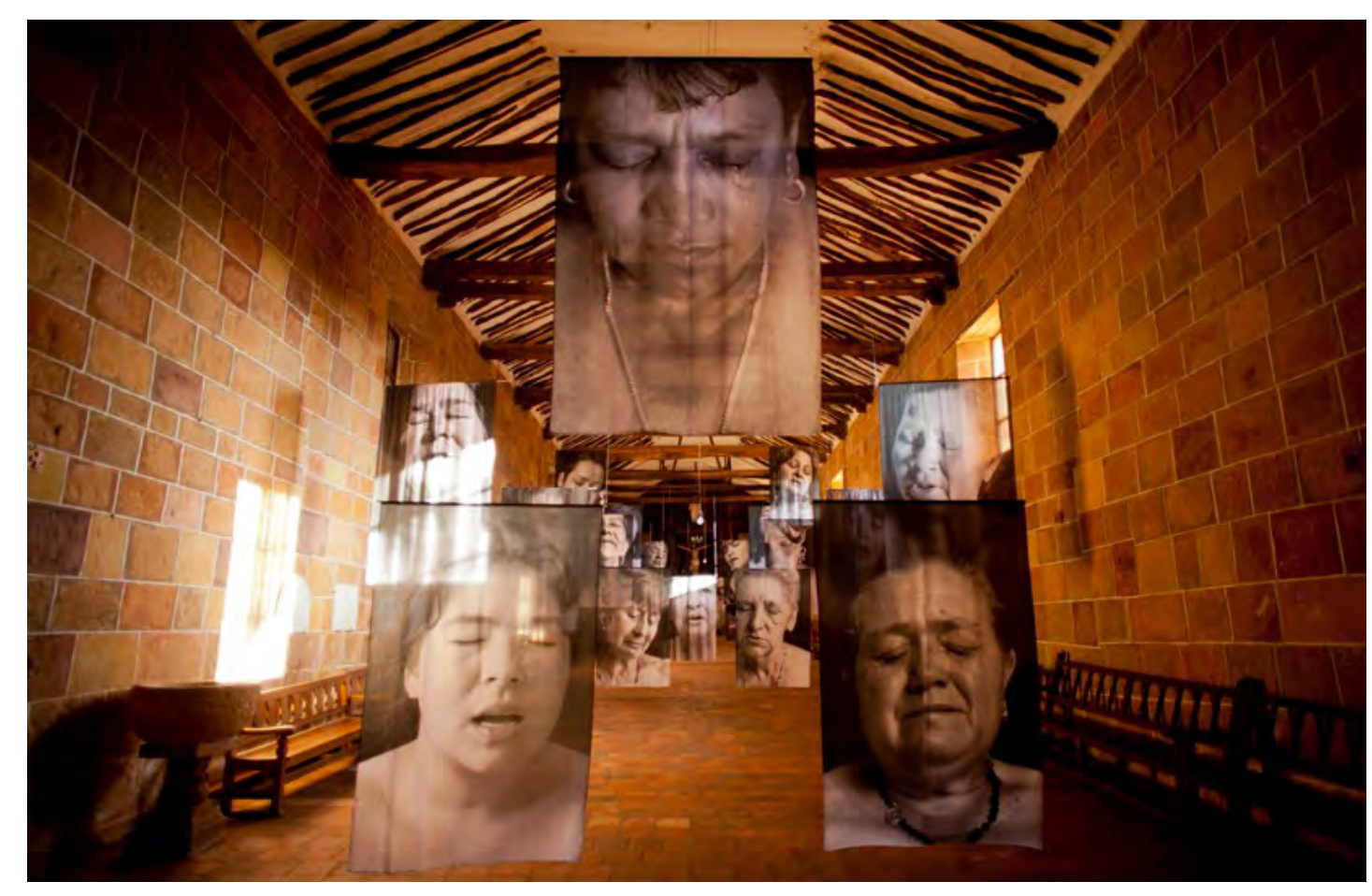

Sudarios. Erika Diettes, 2012. Montaje Capilla de Jesús resucitado, Barichara, Colombia.

Si bien es cierto que mediante estarmente sentido en

lo es que podría construir una identidad problemática. Identificar, por ejemplo, un asesinato con un sacrificio (Cristo), una pena por una ma-

sacre con una pena por una muerte ofrendada (el dolor de María), o una

tortura con un martirio (el suplicio de los santos), podría entenderse,

en el orden de lo discursivo, como algo inevitable (en el sentido de lo

trágico). (Rubiano, 2018, p. 94)

Previo a la realización de las fotografías, Diettes, acompañada de un equipo de profesionales en psicología y sociología, propicia un espacio en el que se disponen las condiciones para la emergencia del testimonio, un proceso de acompañamiento psicosocial que pretende dimensionar las implicaciones que tiene para las mujeres que participaron en el proyecto, recordar de nuevo los hechos que presenciaron y expresarlos inicialmente en testimonios orales, para posteriormente dar lugar a la construcción de la imagen fotográfica. Así precisa Diettes este proceso:

6. Para ver algunas de las imágenes de la serie, conocer los lugares donde ha sido expuesta y consultar documentos e información relevante sobre la obra, pueden consultar el sitio web de la artista: https://www.erikadiettes.com/sudarios-ind

Los Sudarios son imágenes que no se logran en una entrevista. Ese trabajo se hizo acompañado de un proceso psicosocial, de unas jornadas antes del encuentro fotográfico. La gente era consciente de las fotos que queríamos lograr. (Entrevista con José Puentes Ramos en semanarural.com, 27 de agosto de 2018).

De este modo, los retratos intentan captar el instante más álgido del relato y retenerlo en la imagen fotográfica. Sin embargo, esta recreación del testimonio frente a la cámara comporta una serie de aspectos tanto técnicos como éticos y emocionales que resultan problemáticos y generan nuevas tensiones en el proyecto creativo. Al respecto advierte la artista:

Aquí la búsqueda era por el testigo, el que vio, el que estuvo allí presente y quedó para contarlo, entonces eso implicaba unas condiciones físicas diferentes. Yo sabía que iba a ser un formato grande, lo cual implica el uso de un dispositivo que condiciona también ciertas cosas. Las personas no están en una charla cualquiera, es distinto ser fotografiado aquí, sentado en el sofá, a ser fotografiado en un fondo negro. Todo eso 

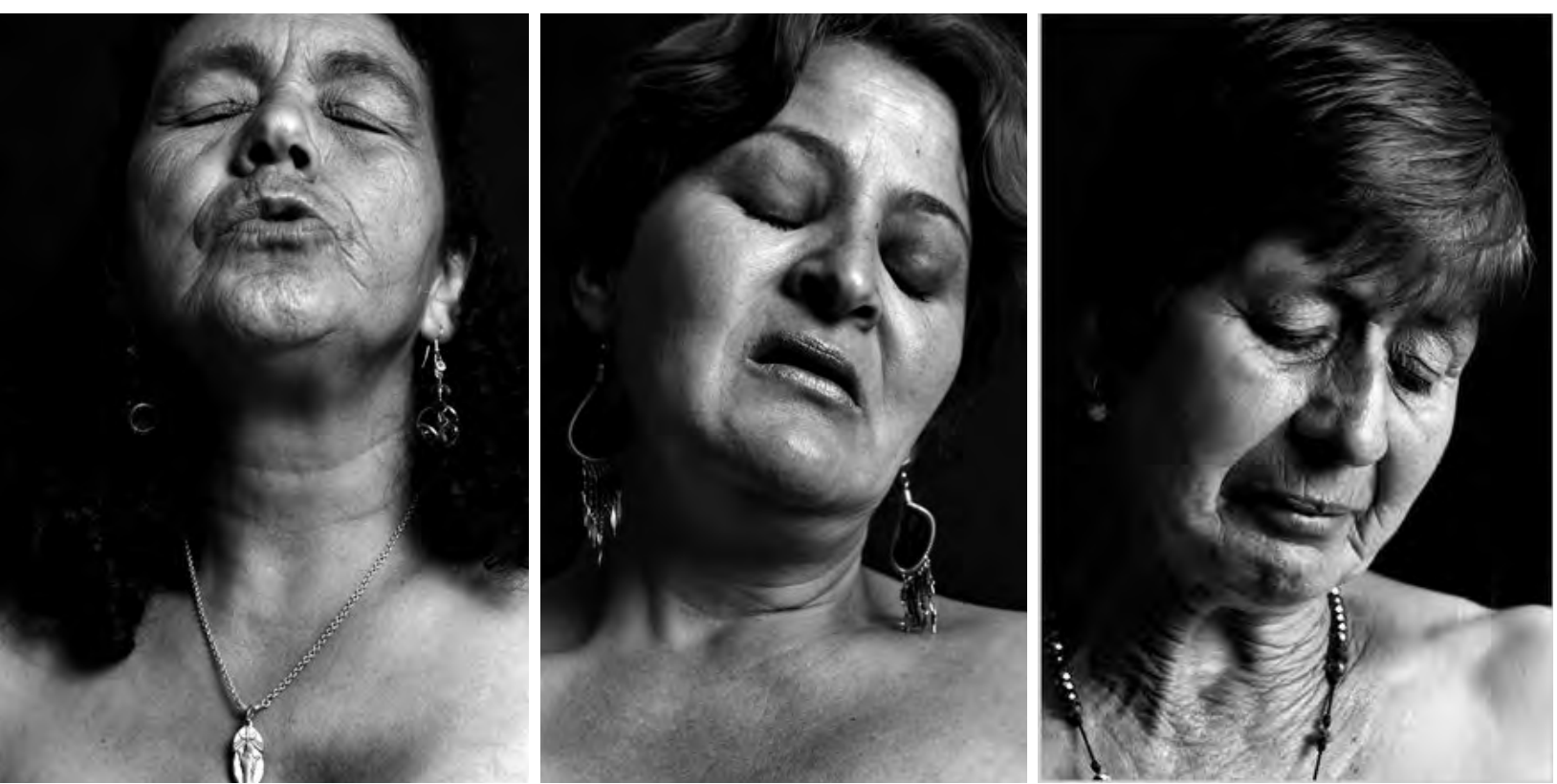

De la serie Sudarios. Erika Diettes. 2011. Fotografía sobre tela

implica una preparación emocional del sujeto ante una circunstancia extraordinaria. (Diettes, comunicación personal, 13 de abril de 2016)

Justamente, algunos de los aspectos más problemáticos de este trabajo creativo y que los críticos han señalado con más detalle -Gamboa (2016), Acosta, (2016) - tiene que ver con el hecho de que se genere una especie de estetización del dolor, una puesta en escena artificiosa, pues es claro que la gestualidad expresada en cada imagen no corresponde al momento y al acto de presenciar la violencia, sino a una rememoración, la cual, además acontece en una especie de representación controlada, mediada por decisiones formales y técnicas, tales como el fondo negro, la textura de la imagen, la tonalidad del blanco y negro, el ángulo y el plano de la imagen, el uso de la iluminación, entre otros aspectos. Señala Gamboa:

No podemos olvidar que la maximización de la referencialidad (el estatuto de "realidad" de estos rostros) se produce mediante una calculada puesta en escena, donde la artista edifica una escenografía (telones, luces, pantallas, cámaras y trípodes), en la que interactúan personas (terapeuta, víctimas y fotógrafa) siguiendo un guion determinado (las víctimas son convocadas para volver a narrar su historia, la terapeuta guía la narración, la fotógrafa “dispara” en los momentos más intensos de la narración). Una vez hechas las tomas, la artista selecciona las imágenes que considere más pertinentes. (Gamboa, 2016, p. 34)

A diferencia de Bocas de ceniza, las fotografías que componen Sudarios borran cualquier referencia al espacio y al tiempo en los que sucedieron los hechos: "la eliminación de las referencias contextuales se hace evidente en la ausencia de nombres propios, localizaciones geográficas, vestimentas o locaciones reconocibles que permitan asociar estas imágenes (el rostro de estas víctimas) con algún hecho concreto de la guerra” (p. 34). En este caso, se hace necesario ir más allá de las imágenes de las mujeres y de la impresión generada por la gestualidad de los retratos, para comprender su condición de mujeres-testigo. No hay palabras que acompañen la imagen y que describan el contexto al que remiten, no aparecen las historias, los espacios geográficos, las identidades de las mujeres y sus familiares-víctimas. En fin, no hay en la imagen fotográfica una referencia directa a los hechos que provocan la visible intensidad de su dolor. En este sentido, Sudarios intenta ubicarse en la compleja relación entre experiencia y lenguaje, dando cuenta de la imposibilidad de traducir, de forma satisfactoria, ese dolor vivido, a la palabra y a la imagen, pues por más que se relaten de nuevo los hechos y los acontecimientos de violencia que los provocaron, hay algo que permanece como intraducible en las palabras. Sin embargo, aludir en este caso a la gestualidad y a la imagen se convierte en un nuevo intento por contener ese dolor para hacerlo visible a los otros.

La imagen fotográfica intenta, como lo ha hecho a lo largo de su historia, capturar un instante, contener el tiempo y el espacio, retratarlo, congelarlo, con la pretensión siempre truncada de conservar todas sus trazas e inscripciones. Aquello a lo que hacen referencia los retratos de las mujeres en Sudarios es a la exteriorización del dolor, a su dignificación ante los otros. Estas mujeres habitan el límite de lo vivible, el límite del relato porque solo allí, en la suspensión del dolor, aparece velada en su opacidad la referencia al desaparecido.

De acuerdo con la socióloga del CINEP Nadis Londoño, quien acompañó el proceso psicosocial con las mujeres que participaron de la obra:

La idea del proyecto no era solo congelar ese dolor, era validarlo y darle un lugar: dignificar el dolor. En nuestra cultura hay un imaginario en 
el que el dolor hay que taparlo, hay que negarlo porque nos hace sentir débiles, indignos. Entonces era un escenario para decirles a estas mujeres, sí, eso pasó. (Londoño, comunicación personal, 8 de julio de 2017)

Dignificar el dolor implica no solo la búsqueda de su reconocimiento colectivo, sino aquello a lo que Veena Das (2008) hace referencia cuando piensa en que quien se ve obligado a presenciar la violencia, debe volver a "aprender a habitar el mundo, o habitarlo de nuevo en un gesto de duelo" (p. 222). En este mismo sentido, podríamos afirmar que, tanto en Bocas de ceniza, como en Sudarios, la potencialidad expresiva del arte no solo tiene que ver con el contenido de los testimonios en tanto reconstrucción de hechos sobre la violencia -incluso, su lugar de enunciación no se configura solo en la construcción metafórica de las letras de las canciones, o en la composición de los retratos- sino en la reunión de todos estos aspectos en una expresión performativa, en la que el cuerpo y la gestualidad del rostro contienen y proyectan significados en sí mismos, pues, tal como advierte Emmanuel Levinas (1991), la interacción, el contacto visual con el rostro del otro, es el inicio, el punto de despliegue de una relación ética, pues instala no solo la posibilidad de percibir al otro, sino la proyección de su exterioridad, su carácter expuesto, su condición de vulnerabilidad. Tal vez por esta razón Levinas afirme que "El rostro está siempre expuesto, amenazado, como invitándonos a un acto de violencia. Pero, al mismo tiempo, el rostro es lo que nos impide matar” (p. 79)

El rostro, entonces, es apertura y cierre, está expuesto ante el otro y su expresividad se dirige a él, pero su significación establece también un límite, una frontera. Los testigos-sobrevivientes que configuran estos dos trabajos creativos, no solo dan cuenta de su experiencia de la violencia, sino que proponen, a través de la gestualidad de sus rostros y de su expresión performativa, una duración, un diálogo que exige interlocutores, que reclama la presencia de los otros, los convoca y al mismo tiempo los confronta.
Ritualidades a la orilla del río

Distintos investigadores sociales han hecho referencia en Colombia al papel de los ríos como eje central de la violencia política y el conflicto armado interno. Refieren cómo su caudal cubre y arrastra con su corriente cuerpos anónimos que los grupos armados pretenden condenar a desaparecer, a que su muerte no tenga un duelo, a quedar como incertidumbre y ausencia en la espera inconclusa de sus familiares.

Puerto Berrío, en el departamento de Antioquia, es un municipio ubicado en la ribera del río Magdalena. Esta ubicación geográfica permitió que en los momentos de mayor intensificación del conflicto armado, los remolinos y la corriente arrastraran de forma recurrente, hasta la orilla del río, cuerpos anónimos, los cuales eran rescatados y sepultados por los habitantes de la población en la zona del cementerio destinada para los NN.

Como respuesta a esta realidad, en el contexto empieza a tener lugar una práctica en la cual algunos pobladores de Puerto Berrío se apropian de las sepulturas de los NN, para pactar una suerte de intercambio simbólico. El "ritual de acogida", como podríamos llamar a esta práctica, inicia con la acción de marcar la sepultura con la palabra "escogido". En los días siguientes, se realizan visitas periódicas en las que se saluda tocando la superficie de la sepultura, como si se tocara una puerta, para despertar el ánima del difunto; esto se complementa con un ritual de rezos y peticiones para la obtención de favores o milagros. Si el ánima del NN les cumple, recibe como retribución un nombre, flores, cuidados para su sepultura y, finalmente, la inclusión de sus restos en el osario familiar o dentro de uno individual, pagado por quien ofrenda, como retribución por el bien concedido.

En la dinámica de esta ritualización inscribe el proyecto artístico Réquiem $N N^{7}$ de Juan Manuel Echavarría, realizado en colaboración con el fotógrafo Fernando Grisalez. El proyecto lo integran tres obras, cada una de los cuales configura un dispositivo independiente: una serie fotográ-

7. El registro completo del proyecto está disponible en el sitio web del artista: https://jmechavarria.com/es/work/requiem-nn/ 
fica, realizada entre 2006 y 2015, cuyo recurso lenticular permite hacer visible el tránsito y las variaciones en el tiempo que se van incorporando en la pared del cementerio de Puerto Berrío, destinada para esos cuerpos anónimos, sin dolientes, cuyas identidades fueron arrebatadas y en un intento por ocultar su propia muerte, entregados al río. En la transición que posibilita el recurso visual, pueden verse las formas particulares de escoger las sepulturas, los nombres asignados por los solicitantes, las flores, las decoraciones dispuestas y los agradecimientos expresados por los favores recibidos.

En segundo lugar, una serie de 12 videos, titulada Novenarios en espera (2012), cuyo contenido refleja el mismo tránsito, ahora narrado a partir de la imagen en movimiento y el énfasis en el detalle de algunas sepulturas concretas. Y por último, un documental realizado en 2013, titulado Réquiem $N N$, de un poco más de una hora de duración, en el que se reúnen entrevistas, relatos de los pobladores y testimonios que dan cuenta de los imaginarios, creencias y significados vinculados con la práctica ritual de los pobladores de Puerto Berrío.

Las imágenes de las dos primeras obras mencionadas operan alrededor del registro del proceso que tiene lugar desde el momento en que el adoptante elige la tumba y señala su elección con la palabra "escogido", generalmente con una escritura informal, para construir una especie de límite, de apropiación. En un momento posterior, empieza el proceso de cuidado de la tumba: aparecen los colores, los nombres otorgados por los adoptantes, las flores, las imágenes de santos para asegurar las mediaciones frente a las solicitudes y, por último, si las peticiones tuvieron eco, los mensajes de agradecimiento y el posterior paso al osario, asegurando nuevas rutinas de rezos, visitas y oraciones periódicas.

De este modo, en su apuesta de montaje e instalación, las fotografías de la obra configuran la recreación de una serie de filas de imágenes de las tapas de las tumbas que aluden y buscan simular algunas de las paredes del cementerio de Puerto Berrío, intentando provocar en el espectador, la misma sensación de estar frente a la pared del cementerio. En las imágenes, pueden advertirse la diversidad de colores, figuras, nombres y decorados que los adoptantes construyeron para asegurar su mediación.
Por su parte, en los videos de la serie Novenarios en espera (2012) se alude de forma más directa al tránsito de transformación de las tumbas, desde el momento en que es elegida, pasando por su apropiación, decoración, hasta el momento del agradecimiento por los favores recibidos. Cada pieza de video reúne en segundos o a lo sumo en minutos, un proceso que puede llevar meses, entre la escogencia de la tumba, hasta el favorecimiento o cumplimiento de las solicitudes y posterior expresión de gratitud.

En cuanto al documental, podría decirse que, sin descuidar una aproximación cargada de un lenguaje poético desde su construcción visual y narrativa, es la poesía la que termina completando el sentido y permitiendo una lectura del contexto en el que se inscriben las prácticas que tienen lugar en las dos piezas antes mencionadas. En el film aparecen las voces de algunos habitantesde Puerto Berrío, de algunos de los adoptantes, del encargado de enterrar los cuerpos anónimos en el espacio de los NN. En fin, un acercamiento al entorno en el que se inscribe la práctica y en el cual se hace posible entender algunas de las razones que movilizan los diferentes momentos de esta acción.

Las prácticas de los adoptantes que dan lugar al proyecto Réquiem NN, hacen visibles algunas expresiones culturales que los habitantes de aquellas zonas en donde tiene mayor incidencia el accionar de la violencia, van construyendo, como forma de tramitar la experiencia de la muerte o de propiciar otros sentidos a la confrontación directa con la barbarie. La acción de acoger y renombrar un cuerpo anónimo se configura aquí en un punto de convergencia entre creencias culturales, religiosas y formas particulares de relación con la muerte, entre las que se manifiesta una especie de obligación moral de enterrar a los muertos y, al mismo tiempo, ver en este acto, la posibilidad de acceder a favores con la mediación de las ánimas de los difuntos, quienes además por el hecho de haber muerto en condiciones violentas, parecen revestirse de una necesidad mucho más apremiante de oraciones e intermediaciones de parte de los vivos. Al respecto advierte Agamben (2005):

La idea de que el cadáver sea merecedor de un respeto especial, de que exista algo como una dignidad de la muerte no es, en rigor, patrimonio original de la ética. Hunde más bien sus raíces en el estrato arcaico 
del derecho, que se confunde en todo momento con la magia. Los honores y los cuidados que se prodigaban al cuerpo del difunto tenían en su origen la finalidad de impedir que el alma del muerto (o, mejor dicho, su imagen o fantasma) permaneciera en el mundo de los vivos como una presencia amenazadora (la larva de los latinos y el eidolon o el phasma de los griegos). Los ritos fúnebres servían precisamente para transformar a este ser perturbador e incierto en un antepasado amigo y poderoso, con el que podían mantenerse relaciones culturales bien definidas (p. 82).

En su interpretación de la serie Novenarios en espera (2012), María del Rosario Acosta (2016) sugiere que la obra de Echavarría, en tanto registro que se detiene en el paso del tiempo entre el acto de los adoptantes de elegir las tumbas y su posterior modificación y expresión de agradecimiento, configura una forma de acompañar el duelo:

solo acompañar, en su presencia vacía, casi fantasmal, estos duelos de los que nadasabemos, de los que quizás entendemos muy poco: la imagen es también aquí como la tumba que retrata, el lugar que resguarda a los muertos, reteniendo para síla verdad de un secreto que no nos es revelado. La obra guarda así el duelo, retiene el juramento de dar duelo a quien ya no está, pero lo hace en su imposibilidad de reemplazar el cuerpo ausente de quien ha quedado para siempre sin la posibilidad de ser llorado, acompañado, velado en su propia muerte. (p. 43)

La investigadora sugiere de este modo que la imagen que transita y da cuenta de la transformación de las tumbas, registra una forma de duelo colectivo; sin embargo, esta connotación resulta problemática, si tenemos en cuenta que más que una práctica colectiva, la práctica de los adoptantes es un acto de voluntad individual que responde a la posibilidad de encontrar en la acogida de un alma martirizada la recompensa de sus favores a cambio de cuidados, rezos y visitas periódicas. Tal práctica tiene lugar, además, en el marco de unas condiciones estructurales de exclusión. Al respecto advierte Rubiano (2017):

Hay, evidentemente, cierta ligereza en las interpretaciones que ven en la adopción de los NN la posibilidad de elaborar un duelo y en Réquiem $N N$ una muestra testimonial de su práctica. En efecto, hay un propósito documental en Réquiem NN: construir un discurso mediante el registro temporal de la transformación de las tumbas, de la intervención que los adoptantes hacen en ellas. El registro es elocuente con respecto a
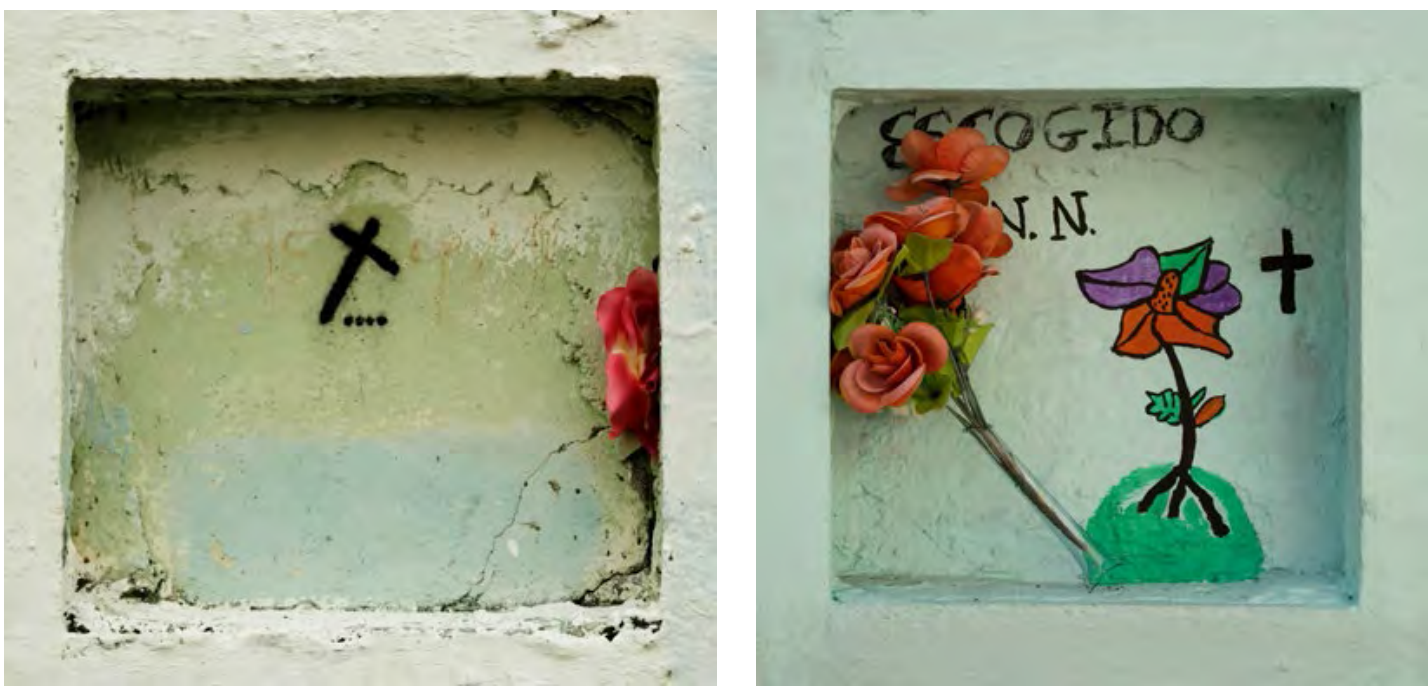
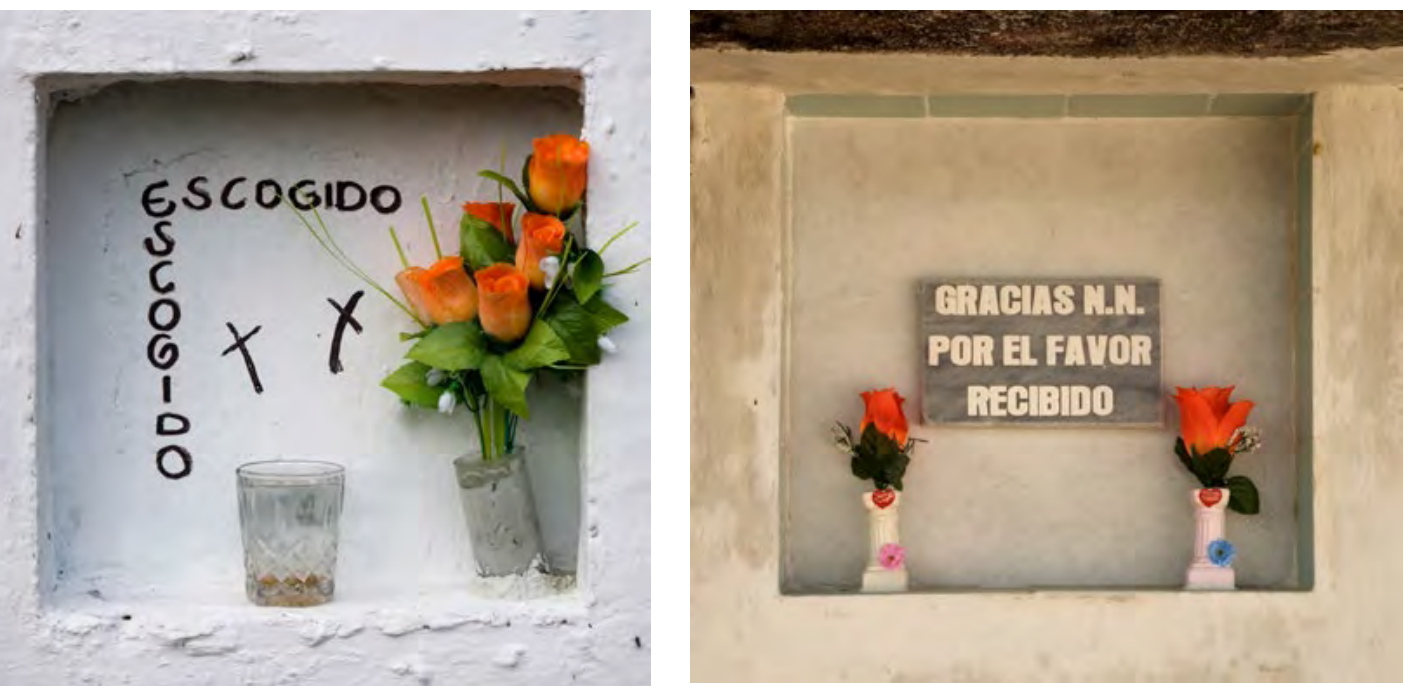

Réquiem NN. Juan Manuel Echavarría, (2006-2015), fotografía lenticular 
lo que ocurre con las tumbas (la serie fotográfica y los videos) y lo que hacen los adoptantes con ellas (el documental). Pero tal elocuencia, quizá, dice menos sobre la integración comunitaria en un ritual, y más sobre la exclusión estructural de una comunidad. (p. 37)

Si bien como señala Rubiano (2017) no sería posible hablar de que la práctica de los adoptantes en Puerto Berrío corresponda a la configuración de prácticas de duelo colectivo o de cohesión de la comunidad, pues tales procesos son más del orden de lo individual y están mediados por la condición de intercambio entre el NN y las solicitudes de los adoptantes, sí podríamos decir que, tal vez, sin buscarlo de forma directa esta práctica termina ejerciendo cierto proceso de resistencia, frente a la lógicas de la violencia ejercida por los actores armados, en el sentido de que contradicen la intención de borrar, de desaparecer los cuerpos y las evidencias de la violencia ejercida. Al volver a traer el cuerpo e insertarlo en el ritual funerario, aunque mediado por un interés específico, devuelve de forma indirecta algo de sentido a su propia muerte y restablece, de cierto modo, su propia dignidad humana.

En cuanto al proceso creativo llevado a cabo por Echavarría y Grisalez, este configura una forma de mediación en la cual la práctica artística registra, vincula y contextualiza esas formas de ser colectivas, abriendo un espacio de reflexión sobre sus implicaciones en el contexto de la violencia política. Al respecto expresa Echavarría:

Yo no escojo el color de la tumba, yo no escojo las flores. Esa es una construcción estética que ya está dentro de la fotografía que yo tomé,

y yo no la hice, yo no la construí: yo no hice el florero, yo no pinté la tumba, es el adoptante el que lo hace. Entonces ya está dentro de la obra. (Echavarría, comunicación personal, 12 de abril de 2016)

Aunque los elementos esenciales de las imágenes de Réquiem $N N$ están dentro del contexto, hacen parte de las prácticas de los habitantes de esta región geográfica, el hecho de traducirlas y conformarlas en una construcción artística desvela de otra manera sus sentidos e implicaciones para una población que, en palabras de María Victoria Uribe (2008), "es un pueblo de testigos y sobrevivientes" (p. 181), pues, tal como ya hemos mencionado antes, el testimonio de la violencia no solo se refleja en las narraciones objetivas de los hechos de violencia, sino que, como en este caso, tendrían que ver también con las formas como la violencia se instala y se incorpora en las dinámicas colectivas de los contextos sociales y geográficos en los cuales esta acontece. De este modo, el testimonio se expresa también en trazas y prácticas culturales que son naturalizadas por los grupos sociales, permitiéndonos reconocer otras de las dimensiones expresadas en los rituales colectivos que se van incorporando en las formas de ser de los grupos que viven las dinámicas de la violencia de forma cercana.

En otro contexto geográfico, la referencia al río y a la desaparición forzada, tiene lugar en el proyecto Magdalenas por el Cauca, creado por los artistas Gabriel Posada y Yorlady Ruiz. Como ya se señaló atrás, la obra se gesta en el contexto de una residencia artística realizada por Posada en 2008, en la cual, como uno de sus productos de creación, pinta tres rostros de mujeres en gran formato, las cuales llevan en sus manos la fotografía de un familiar desaparecido . Las pinturas fueron instaladas en balsas que recorrieron la ribera del río Cauca, guiadas por balseros de la zona, en un trayecto que inició en el puente de Anacaro en Cartago, Valle del Cauca, para transitar hasta el municipio de La Virginia, Risaralda y continuar luego su recorrido a solas por el cauce del río, con un destino incierto.

$\mathrm{Al}$ año siguiente de esta intervención, los artistas establecen un primer vínculo con la Asociación de Familiares de Víctimas de Trujillo, Valle del Cauca (AFAVIT) y empiezan a proyectar un proceso de creación de carácter colaborativo, en el cual su trabajo artístico se articula con los procesos de construcción de memoria colectiva, llevados a cabo por dicha asociación.

Para la X Peregrinación en Conmemoración de las Víctimas de la Masacre de Trujillo, llevada a cabo en abril de 2010, el colectivo de artistas, en colaboración con un grupo de familiares de víctimas de AFAVIT, construyen siete balsas que sirven de soporte a las imágenes de los rostros de algunas de las mujeres familiares de víctimas, fijadas en lienzo, y crean una obra escultórica llamada La Ofelia de Trujillo, en alusión a la imagen de Alba Isabel Giraldo, sobrina del Padre Tiberio Fernández, ambos asesinados en Trujillo. El vestido de la escultura portaba los retratos de 25 víctimas, dibujados por los familiares que participaron en el proceso creativo. Cada imagen narraba una historia, aludía a un hecho o sacaba a flote una 

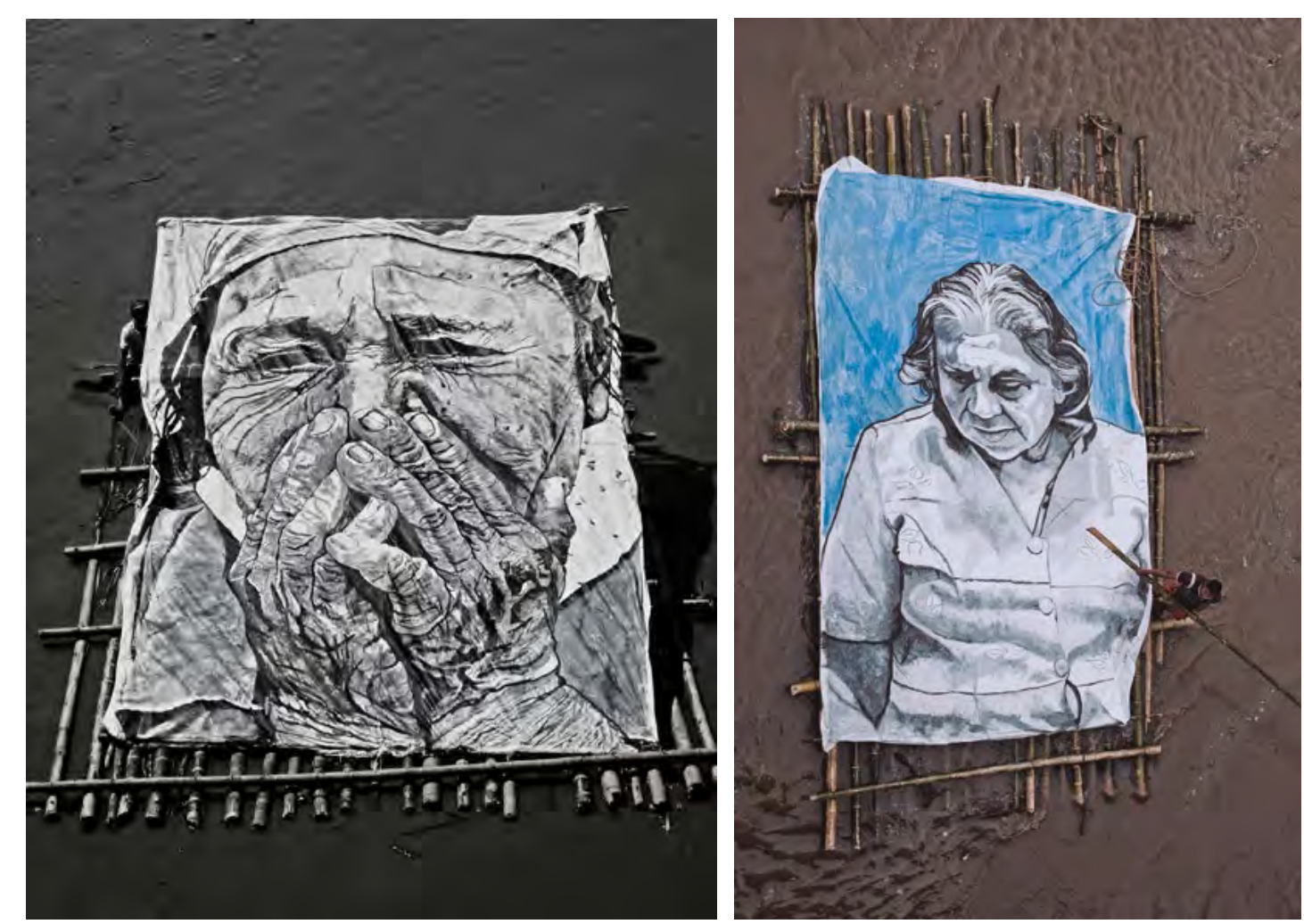

Magdalenas por el Cauca, Gabriel Posada, Yorlady Ruiz, 2009-2010.
Fotografías: izq. Gabriel Posada; der. Rodrigo Grajales

serie de testimonios relacionados con los años de la masacre de Trujillo, Valle del Cauca y la vivencia azarosa del tiempo posterior a esta serie de hechos. En relación con esta experiencia Yorlady Ruiz relata:

Las imágenes y las historias se fueron integrando en nuestros talleres.

Hijos, hijas, hermanas, hermanos, esposas, madres, sobrinos, amigos continuaron su duelo en la realización de las pinturas que finalmente en la Peregrinación del 17 de abril de 2010 recorrieron las calles de Trujillo, el Parque Monumento, sus osarios, el mausoleo del padre Tiberio Fernández, para finalmente llegar a la orilla del río Cauca, en la población de Riofrío y allí, en una sola voz se consagraron sus aguas, en un acto simbólico donde participaron casi cuatrocientas personas venidas de varias regiones de Colombia (Ruiz, comunicación personal, febrero 27 de 2019)

Las balsas, dispuestas como parte de la procesión conmemorativa, navegaron de nuevo el cauce del río Cauca, transportando los registros de los dolientes de la barbarie, que insistían en recordar a sus seres queridos, reclamar justicia y el esclarecimiento de los hechos que ocasionaron sus desapariciones y asesinatos. La memoria, reconstruida de manera laboriosa y colectiva, se desplazó por el río, devenido escenario de muerte, para confrontar el pasado, para seguir interrogándolo, para configurar las posibilidades de realización del duelo.

En el marco de esa misma peregrinación, Yorlady Ruiz realiza el performance La Llorona. En tal acción, la artista retoma una de las figuras legendarias de mayor presencia en las narraciones orales de esta zona del país y de muchos otros contextos latinoamericanos, de una mujer que deambula por los caminos rurales, cerca de los ríos, llorando y lamentándose por sus hijos desaparecidos. La acción es articulada al contexto social y político de Trujillo en donde año tras año un grupo de mujeres, acompañadas por otros miembros de la comunidad, habitantes de las veredas y corregimientos aledaños, donde que se perpetró la masacre, conmemoran la desaparición de sus seres queridos con una acción simbólica y colectiva de peregrinación,

Yorlady recorre la orilla del río, encarnando la imagen del ser legendario. El llanto y el clamor por los hijos desaparecidos del personaje de la leyenda se actualiza en cada una de las madres que aún esperan, tal vez ya no encontrar a sus hijos con vida, pero por lo menos saber qué pasó, antes de que sus cuerpos se sumergieran en el cauce del río Cauca e iniciaran su recorrido anónimo. Su cuerpo es también el símbolo del cuerpo que emerge de la profundidad de las aguas. En tanto cuerpo ex-puesto, la artista se sitúa entre lo dicho y lo no dicho, entre el adentro y el afuera del testimonio, en lo que la palabra no alcanza; su gestualidad se ubica en lo que cualquier relato objetivo establecerá como silencio e indeterminación; su función no es solo representativa, no busca solo recrear o ficcionar lo sucedido; también pretende ex-poner una presencia, materializar el recuerdo, el cuerpo del artista es al mismo tiempo soporte, medio e inscripción de la memoria.

Aludiendo también al río como escenario de desaparición y muerte, Erika Diettes, presenta en 2008 el trabajo denominado Río abajo. El eje central de este proyecto lo conforman una serie de fotografías en gran 


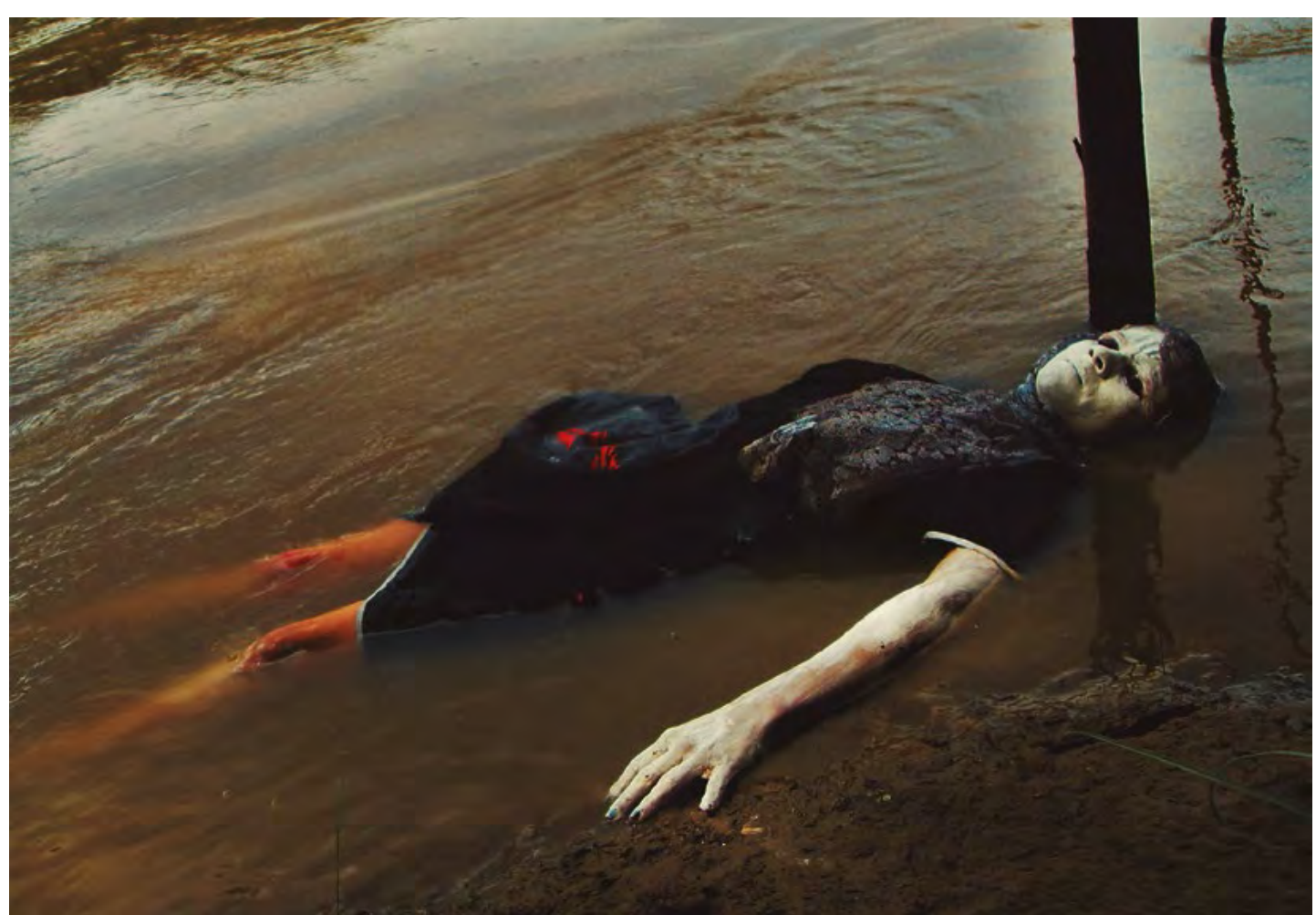

Performance, La Llorona, Yorlady Ruiz, 2013. Fotografía: Gabriel Posada

formato, impresas en cristal, las cuales contienen imágenes de prendas de vestir y objetos personales que familiares de víctimas del conflicto armado, atesoran como único rastro físico de sus seres queridos. Diettes recolecta estos objetos y prendas a manera de préstamo, con el compromiso ineluctable de ser devueltos, una vez realizados los registros que conforman el trabajo de creación.

Río abajo inicia el ciclo de un proceso creativo llevado a cabo por Diettes, a partir del contacto con familiares de víctimas de distintos lugares y geografías del país. La obra configura formas de mediación artística frente a la experiencia de la violencia política. En este caso, toma como eje central el fenómeno de la desaparición forzada y como principal escenario algunos municipios del oriente antioqueño. Diettes recorre estos municipios y corregimientos, establece vínculos con asociaciones de familiares de víctimas e inicia una serie de diálogos en los que, además de socializar los alcances y perspectivas del proyecto, se genera un espacio para hablar, narrar y exteriorizar relatos y testimonios que se van reuniendo como una forma de ir hilvanando un archivo de narraciones. Ellas darán lugar a una cartografía de experiencias cuyo factor común es la violencia y la desaparición. Alrededor de esta experiencia, relata Diettes:

Los primeros encuentros fueron desgarradores, hubo muchas preguntas, tanta necesidad, tanto dolor y yo haciendo fotos, me lo pregunté una y otra vez. (...) Cuando tú planteas una obra como Río abajo, sabes que absolutamente todo se perdió antes; entonces lo que estás haciendo de cierta manera nace muerto, en el sentido en el que sabes que no vas a revivir a nadie, en el que sabes que la historia no va a poder ser diferente, en el que sientes que no hay redención posible. (Diettes, entrevista personal, 13 de abril de 2016)

A partir de esta condición podríamos preguntarnos: ¿cómo proyectar un trabajo artístico teniendo como punto de partida la sensación de impotencia frente al dolor de los demás?, teniendo además plena conciencia de que el arte no está en capacidad de resolver la ausencia y el daño causado por la guerra, ni siquiera está en capacidad de generar un espacio de resolución del duelo.

Siguiendo la línea de estos cuestionamientos, distintos académicos y sectores de la crítica especializada han visto en trabajos artísticos como los de Echavarría, "Magdalenas por el Cauca” y Diettes, simples formas de estetizar la violencia y el dolor. Sin embargo, tales miradas pasan por alto otra serie de aspectos que tienen lugar en estos procesos y que, en este caso particular, se encuentran más allá de las imágenes que componen la obra y su exhibición, tal como lo analiza Ileana Diéguez (2013):

De ninguna manera afirmo que el arte propicie un espacio real para los duelos. La imposibilidad del duelo pasa por las deudas de la justicia, por el olvido, la indiferencia, la impunidad y la carencia absoluta de ritos para aceptar y procesar la muerte. Pero dignificar el dolor, propiciar un lugar digno para los vestigios atesorados por los familiares, reunirlos en una ceremonia pública donde lo expuesto es mucho más que una obra de arte y deviene -sin que sea la artista quien lo determine- ritual fúnebre, es quizás la única posibilidad de realizar actos de duelo en un contexto -que como tantos de este continente- no considera el sufrimiento, el dolor y la justicia como problemáticas primordiales de 

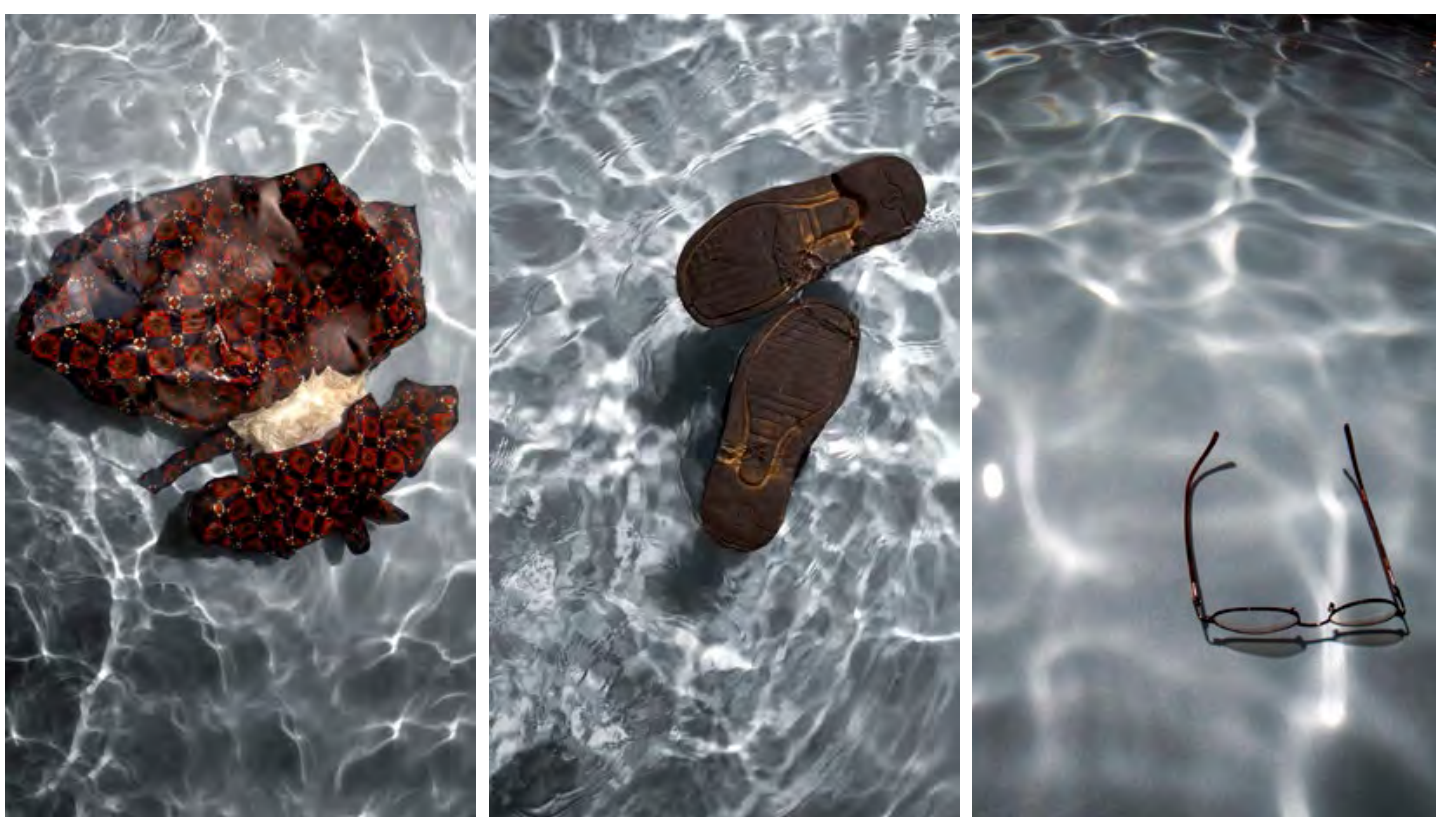

De la serie Río abajo. Erika Diettes, 2008. Fotografía sobre vidrio

sus comunidades. Es propiciar, desde las configuraciones artísticas, un lugar para llorar la muerte. (p. 237)

Las primeras exposiciones de Río abajo tuvieron lugar el 5 y 6 de septiembre de 2008 en los municipios de Granada y La Unión, en el oriente antioqueño; zona que ha tenido un fuerte impacto de la violencia política, por la confluencia de intereses territoriales y militares detodos los grupos armados que han protagonizado el conflicto armado en Colombia. Posteriormente, la exposición fue haciendo presencia en 18 municipios y corregimientos de la misma zona geográfica, en los cuales Diettes había establecido los vínculos iniciales con los familiares y dolientes, al tiempo que representaban el lugar de origen de algunas de las personas que habían portado las prendas, que ahora retornaban en forma de imagen al espaciosocial del que fueron arrebatados por la violencia política.

Bajo la vigilancia “sutil” de los actores armados que operaban en esta zona geográfica (para ese entonces la presencia de grupos paramilitares era todavía una realidad, a pesar del proceso de desmovilización de sus estructuras entre los 2003 y 2006), las imágenes en formato pequeño se dispusieron en salones, casas de la cultura y otros sitios acondicionados para tal fin en cada municipio o corregimiento.
Diettes relata cómo cada familia iba llegando al espacio, con el fin de encontrar la fotografía de la prenda de vestir o el objeto de su ser querido, para ofrendarlo con velas encendidas, oraciones, cantos, llanto. Se trataba de una especie de conmemoración del duelo que no pudo cerrarse por la incertidumbre de la desaparición y la ausencia de los cuerpos de sus familiares como plena certeza y confirmación de su muerte:

La primera exposición de Río abajo fue en el municipio de Granada (Antioquia), se hizo dentro de la jornada de la luz, un evento que las organizaciones de víctimas realizan una vez al año. Allí siempre hacen una marcha con velas, apagan las luces del pueblo y la gente sale con velas pidiendo por la paz. Entonces decidimos que el punto final para terminar la marcha era la exposición de Río abajo; allí es donde entra el elemento de las velas realmente a hacer parte de mi obra. (Hay que tener en cuenta que los espectadores ahí no son cualquier espectador, son las madres que van a buscar el cuadro de su hijo o su familiar); ahí entendí también que la "exposición” tiene un valor diferente. Una señora me decía "yo pensé que ustedes iban a poner los objetos en el piso" y lloraba frente al cuadro y decía "me parece increíble verlo enmarcado". Se establece una relación con el marco, con el cuadro, con la elevación del mismo. Hay una cuestión allí de mostrar dignamente, de honrar la memoria de una forma que no había podido existir porque parte de las dinámicas del conflicto en Colombia fue prohibir el duelo. (Diettes, comunicación personal, 13 de abril de 2016)

De este modo, Río abajo configura un rol de mediación entre la condición de desaparición de los cuerpos de las víctimas y la necesidad de tramitar el duelo de los dolientes. Los recuadros que contienen las imágenes representan la posibilidad de contener, no solo los objetos como huellas de las personas desaparecidas, sino además la creación de un espacio ritual para contener y tramitar el duelo, para conmemorar, a pesar de la ausencia de los cuerpos, la mediación con un rastro, con una huella física, con un objeto o una prenda de vestir, que en el pasado había hecho contacto con la piel, había vestido el cuerpo, había cubierto un cuerpo real, un cuerpo familiar, una presencia anhelada.

En este sentido, si bien los componentes formales y materiales del trabajo creativo estaban definidos desde el principio del proyecto por parte 
de la artista, es importante advertir que la consolidación del espacio conmemorativo solo se hizo posible a partir de la relación establecidapreviamente a la materialización de las imágenes, entre la artista y los dolientes y la apropiación por parte de ellos (ya en el contexto de las primeras exposiciones) de las imágenes que retornaban a su espacio social. Muestra de ello, es que la decisión de poner velas encendidas alrededor de cada imagen y en el espacio común de la sala surge, no de unadecisión de Diettes, sino del gesto de los dolientes, quienes en las primeras exposiciones ofrendaron con velas encendidas el encuentro con las imágenes que remitían a las prendas de sus familiares desaparecidos.

\section{Ruinas, indicios y rastros de humanidad}

La referencia a lo residual, a los rastros de los acontecimientos que quedan en el tiempo y en el espacio, representa un factor común en las prácticas artísticas contemporáneas que se ocupan de problematizar las

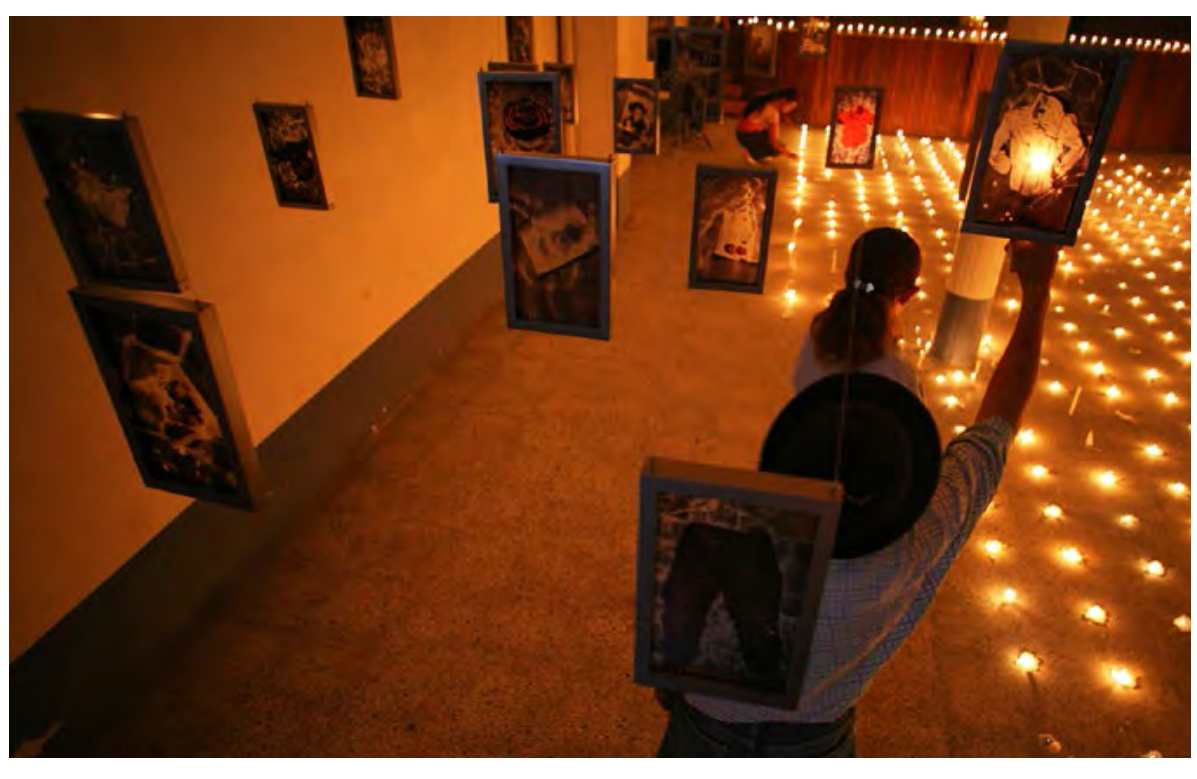

Exposición Ría abajo. Cocorná (Antioquia), 2009 relaciones entre estética y política (Bourriaud, 2015). Sin embargo, mucho antes Walter Benjamin (2008), en sus Tesis sobre la filosofía de la historia, advertía, en la referencia al pasado, cómo las ruinas, de forma simultánea y paradójica, contenían tanto las huellas de la destrucción, como las trazas de la vida. Es decir, las ruinas se relacionan con lo que ha pasado, con las sedimentaciones del tiempo, que se niegan a desaparecer del todo, que insisten en reclamar algo de un tiempo distinto.

Uno de los trabajos artísticos que aborda de forma directa esta referencia a las ruinas, en el contexto de la violencia política en Colombia, es la serie fotográfica Silencios de Juan Manuel Echavarría. El punto de inicio de este proyecto creativo está relacionado con los hechos que tuvieron lugar el 10 de marzo de 2000, cuando un grupo de 300 paramilitares del Bloque Héroes de Montes de María, al mando de alias "Juancho Dique" y "Diego Vecino" entraron al corregimiento de Mampuján, reunieron a la población en la plaza central, y con intimidaciones y amenazas les ordenaron abandonar el pueblo, de manera perentoria. La salida de la comunidad de Mampuján la madrugada del 11 de marzo configura otro de los éxodos que han marcado la historia reciente del conflicto armado en Colombia. Diez años después, el 11 de marzo de 2010, un grupo considerable de familias decidió volver al viejo Mampuján, con el fin de conmemorar una década de su desplazamiento. Echavarría, quien fue invitado a esta conmemoración, realizó con los habitantes del corregimiento un recorrido por lo que alguna vez fueron sus calles, sus casas ahora en ruinas y apropiadas por el silencio y la imponencia de la naturaleza que, en forma de humedad, de maleza y vegetación, reclamaba su lugar entre los muros y los espacios abandonados.

Dos imágenes marcan, entonces, el inicio del proyecto fotográfico denominado Silencios. La primera, es un tablero de una vieja escuela en el que las vocales parecen desplazarse de la superficie de la pizarra, prolongando en su desplazamiento, el silencio. La fotografía recibe el título de $L a$ $O$, justamente la letra faltante en la imagen, como una forma de resaltar la ausencia, el silencio de esas letras que no volverán a ser pronunciadas por los profesores y los niños que habitaron cotidianamente esa escuela, ahora transformada en ruina. 


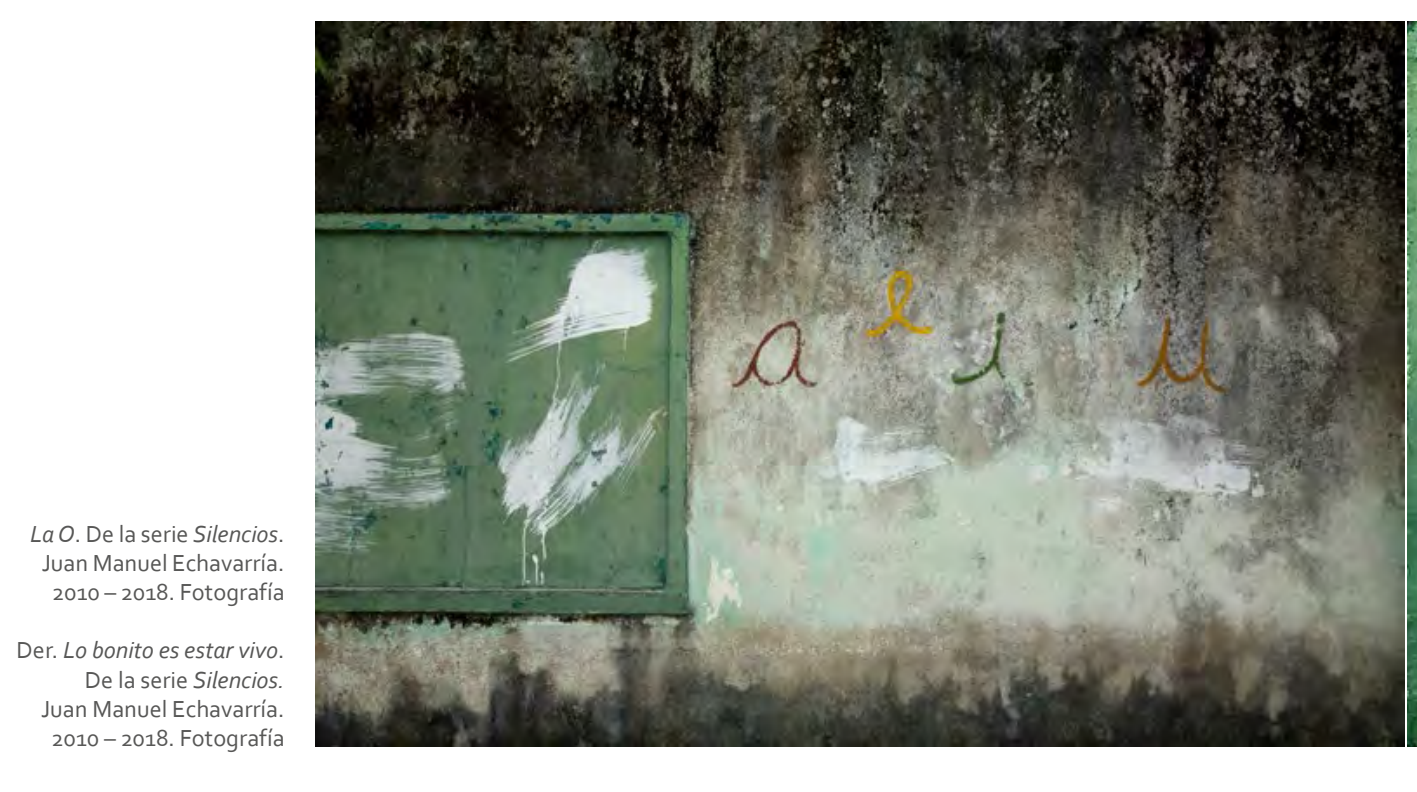

La segunda imagen es la de un tablero deteriorado por la humedad, en el que alguien decide hacer una sencilla pero significativa inscripción $L o$ bonito es estar vivo. Tal inscripción es casi imperceptible a primera vista; es necesario detener la mirada en el tablero para advertir su relieve, lo cual se convierte en un aspecto destacado en el trabajo creativo de Echavarría: la capacidad de observar, la potencia de la mirada, poder mirar más allá de las ruinas y de las implicaciones evidentes de las huellas de la violencia, encontrar, como advertía Benjamin, en esas ruinas, las claves del pasado, la violencia de lo sucedido.

Estas dos imágenes se convierten en la motivación inicial de Echavarría para recorrer alrededor de 60 veredas en Montes de María y otras zonas del país, como Caquetá y Chocó, fotografiando ruinas, tableros de escuelas abandonadas, como una forma de registrar algunos de los vestigios de la guerra. Tales espacios se convirtieron, a partir de la incursión de la violencia, en lugares de paso y refugio para los combatientes, en albergues provisionales para quienes resultaron desplazados por la guerra, en ruinas que poco a poco van dejando que la maleza, las raíces de los árboles y la vegetación de la zona invadan, o mejor, recuperen, con su paso constante y vivo, su lugar. Sostiene Echavarría:

A través del proceso creativo me he dado cuenta que [sic] lo importante es el camino, no solo el tablero. Porque allí escucho historias,

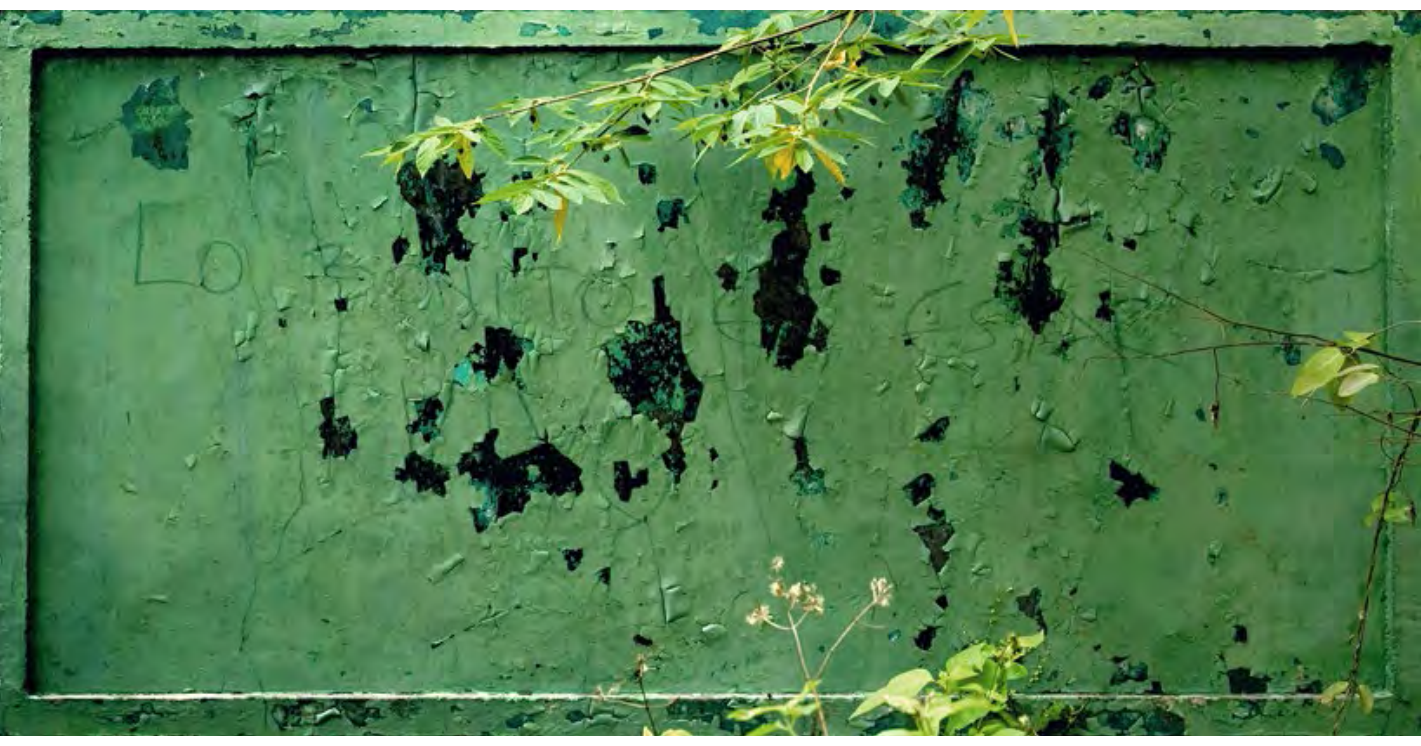

entro a casas campesinas, converso con los moradores, veo el fogón de leña, veo sus chivos, sus gallinas, me siento con ellos, les escucho sus historias, me brindan un tinto. La mayoría de las veces he sentido una enorme hospitalidad y todo eso va oxigenando el camino hasta llegar a la escuela y tomar la foto de ese tablero. Esos caminos me dejan ver la geografía de la guerra. (Echavarría, comunicación personal, 12 de abril de 2016)

De esta suerte, cada imagen final, la fotografía de cada tablero lleva también impresas las huellas del tránsito por el camino que conduce a él. Cada fotografía lleva contiene un relato previo, un paisaje que le da contexto, una ruta escarpada, una serie de rememoraciones que permiten dimensionar la inscripción de las huellas de la violencia en esta zona del país. De nuevo advierte Echavarría:

Yo creo que esos tableros son testigos; detrás de ellos está la muerte, la masacre de campesinos, el desplazamiento forzado de familias enteras. Nos hablan de la educación cortada, fracturada por la violencia. (...) pienso que cada tablero, cada una de esas aulas, también es el corazón de las tinieblas. (Echavarría, comunicación personal, 12 de abril de 2016)

Además de las ruinas que señalan indicios de las dinámicas colectivas que alguna vez tuvieron lugar en algún espacio geográfico, también los 
objetos y su disposición en los espacios domésticos hacen referencia a una forma y una materialidad inmersa en las relaciones particulares de una trayectoria de vida. En su desgaste contienen el paso del tiempo, la intensidad de su uso, el tiempo acumulado que alguien dedica a relacionarse con las cosas, a determinados oficios y acciones que configuran el sentido de la cotidianidad.

Esta valoración de los objetos como huellas e indicios de una vida, cobra especial dramatismo y expresividad en el trabajo artístico denominado Relicarios de Erika Diettes. La instalación, presentada por primera vez en noviembre de 2016 en el Museo de Antioquia, la integran 165 recuadros de tripolímero de caucho de 30x30 centímetros. Dada su textura translúcida, cada pieza contiene y permite ver una serie de objetos que pertenecieron a víctimas de distintas formas de la violencia derivada del conflicto armado, donados a la artista por familiares de estos. Cada recuadro está separado del suelo por un soporte de madera negro y se encuentra contenido en una urna de vidrio.

La producción y realización de este trabajo implicó para Diettes un proceso que se prolongó alrededor de seis años, en los cuales se ocupó de

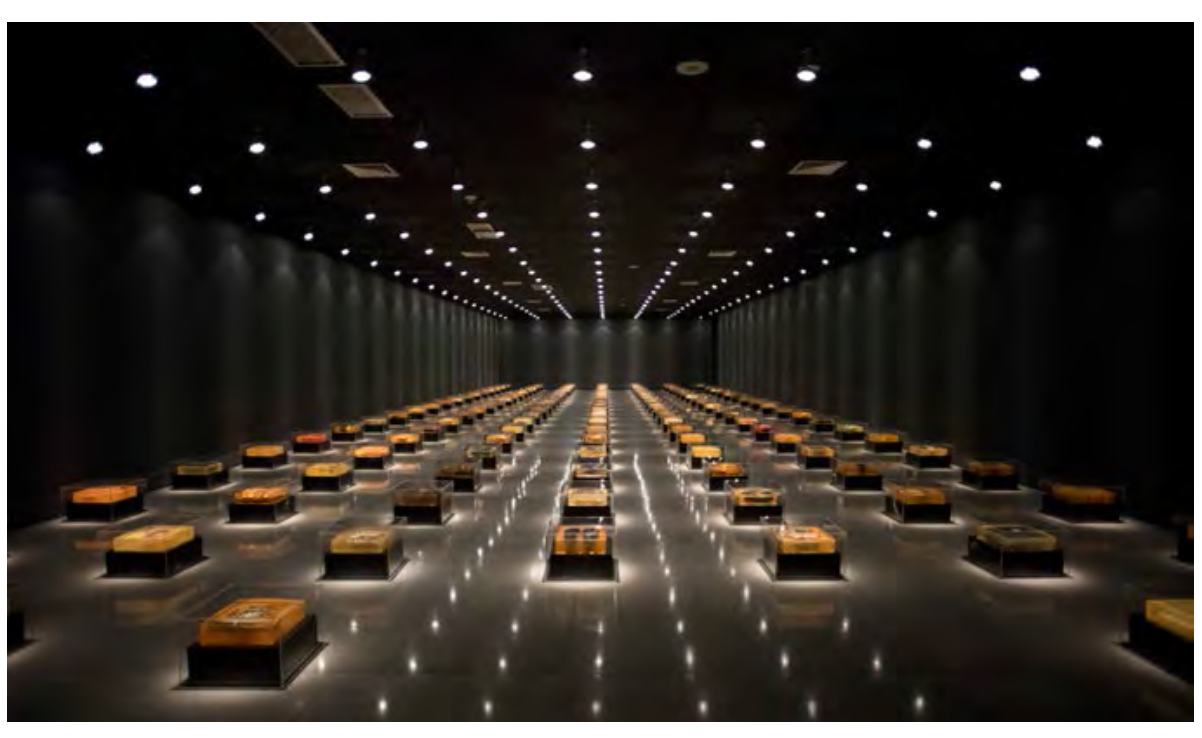

Exposición Relicarios. Erika Diettes. Museo de Antioquia, 2016 establecer con cada una de las familias un vínculo, un diálogo prolongado, primero alrededor de la experiencia de la violencia y, posteriormente, en torno al sentido y el significado que para cada una de ellas tenían los objetos entregados como donación al proyecto creativo. Se trataba de una metodología similar a la abordada por la artista en trabajos anteriores, como Río abajo y Sudarios, a los cuales ya hemos hecho referencia.

De este modo, aparecen en el espacio de la sala, distribuidos en seis hileras que aluden al recorrido por un cementerio, objetos encapsulados, entre los que pueden verse una máquina de afeitar, un cepillo de dientes, un peine, algunas prendas de vestir que hicieron parte del acontecer rutinario de la cotidianidad, en el cual, justamente, se configura la singularidad de las personas. Aparecen también cartas escritas a puño y letra, fotografías, herramientas, que nos hablan de un rol, un trabajo, una forma particular de "haber sido" en el mundo. Con estos relicarios, lo sabe la artista, se va tejiendo ese vínculo entre la ausencia y la presencia, entre la vida y la muerte.

Antes de la apertura de la exposición, Diettes y su equipo de trabajo se reúnen por primera vez con la totalidad de las familias que donaron sus objetos. Recorren la sala y se reencuentran con los objetos previamente donados, ahora ubicados al lado de los objetos de otras familias, dispuestos además en una forma que remite tanto a una condición fúnebre, como a la posibilidad de una especie de conmemoración colectiva. De este modo, cada relicario es al mismo tiempo particular, íntimo, específico, pero también colectivo y universal; representa, más allá de un recordatorio, una ligazón con una vida que tuvo presencia.

Relicarios propicia un lugar de conmemoración, un espacio de reunión, no solo para los dolientes y familiares de las víctimas, sino para el colectivo social en general. Es una obra que hace referencia no solo a los objetos de un grupo de personas que desaparecieron en las dinámicas absurdas de la guerra, sino también a las huellas de lo que hemos venido siendo como sociedad, de nuestras formas particulares de vida colectiva.

Esta alusión a los objetos como huellas que contienen las marcas de una forma de vida está presente también en el trabajo artístico ¿De qué sirve una taza?, realizada en 2017 por Juan Manuel Echavarría, en cola- 


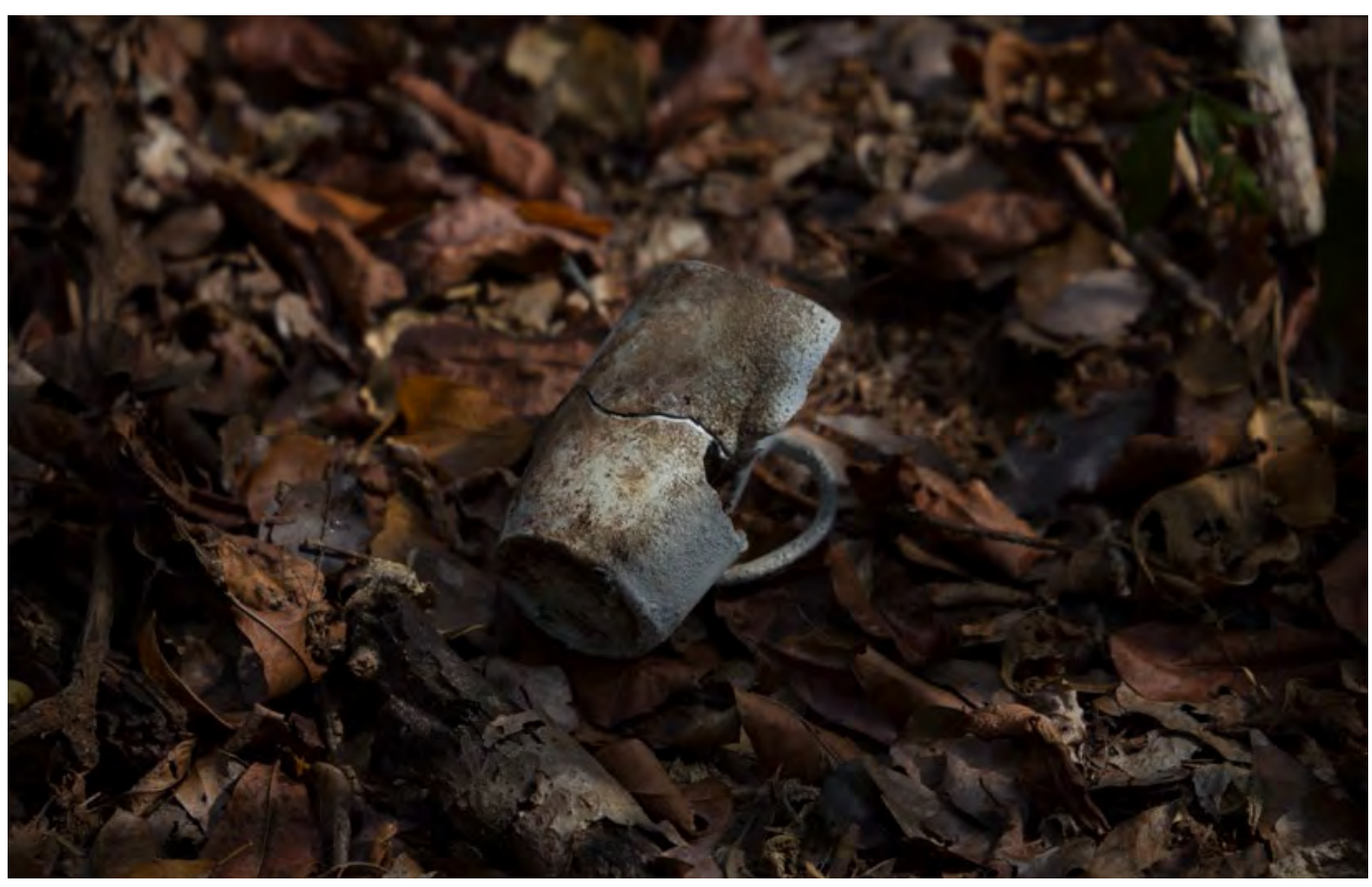

De la serie ¿De qué sirve una taza? Juan Manuel Echavarría, Fernando Grisalez, 2017. Fotografí

duda, lo frágil. En un espacio bombardeado, en cuyas ruinas aparece el nombre de Pedro, pervive la inscripción bordada con hilo rojo en la solapa de un camuflado.

De esta manera, el trabajo artístico de Erika Diettes, Juan Manuel Echavarría y el colectivo "Magdalenas por el Cauca”, tiene que ver más que con la memoria, con la arqueología, es decir, más que ser un trabajo que busque activar formas de recordación sobre hechos violentos o documentar acontecimientos específicos, se detiene en gestualidades, ruinas, objetos personales o incrustados en la selva, prácticas fúnebres que son reunidas, ordenadas, recubiertas de sentido y presentadas a los otros con un nuevo matiz, con una nueva significación. Su rol como artistas gravita en esa doble condición de mediadores y traductores. Proyectan, en todo caso, una apuesta por resignificar la experiencia de la violencia política, por hacer transmisibles algunos de sus sentidos e inscripciones.

Tales prácticas configuran archivos culturalmente transmisibles y, por tanto, formas de arqueología de la violencia que atienden a esa naturaleza de resignificación a la que apunta Foucault (2010) en La arqueología del 
saber, con relación a la historia. Aquí el documento ya no responde al ordenamiento lineal y limpio del pasado, a su memorización y fosilización en el registro, sino más bien a la enunciación y, en este caso, a la visibilización como estrategia configuradora que amplía las posibilidades de comprensión de sus rupturas y discontinuidades para el presente y el futuro.

El lugar del arte implica una distancia crítica frente al marco de las alteridades que conforman la violencia y la guerra, lo cual no compromete la negación de su compromiso con la realidad política, sino más bien que sus formas concretas de intervención no terminen ahogándose en la expresión formal de la ideología o en lecturas victimizantes y le permita, por el contrario, una labor rebelde, al mismo tiempo poética y política de constante pregunta, de constante cuestionamiento frente a los relatos mediáticos y objetivables que llaman al olvido, a las conclusiones definitivas, a los informes finales.

\section{Referencias bibliográficas}

Acosta, M. del R. (2016). Resistencias al olvido. Memoria y arte en Colombia. Universidad de los Andes.

Agamben, G. (2000). Lo que queda de Auswitchz. El archivo y el testigo. Homo Sacer III. Pretextos.

Bal, M. (2010). De lo que no se puede hablar. El arte político de Doris Salcedo. The University of Chicago Press.

Bal, M. (2010). "Arte para lo político”, en Revista Estudios Visuales. No. 7, enero. https://docplayer.es/2765690-Mieke-bal-arte-para-lo-politico.html

Benjamin, W. (2008). Tesis sobre la historia y otros fragmentos. Itaca.

Bourriaud, N. (2008). Estética relacional. Adriana Hidalgo Editora.

Bourriaud, N. (2015). La Exforma. Adriana Hidalgo Editora.

Castillejo, A. (2008). Los archivos del dolor. Ensayos sobre la violencia y el recuerdo en la Sudáfrica contemporánea. Universidad de los Andes.

Das, V. (2008). Sujetos del dolor, agentes de dignidad. Universidad Nacional de Colombia, Pontificia Universidad Javeriana, Instituto Pensar.
Diéguez, I. (2013). Cuerpos sin duelo. Iconografías y teatralidades del dolor. Ediciones Documenta/escénicas.

Foster, H. (2001). El retorno de lo real. La vanguardia a finales de siglo. Akal. Foucault, M. (2010). La arqueología del saber. Siglo XXI.

Gamboa, A. (2016) "Víctimas del arte: Reflexiones en torno a la representación de la guerra en Colombia”. En Calle 14, 11 (19), 30-43.

Hernández, Ibis. (2015). “Transferencias: de lo cotidiano al arte, del arte a lo cotidiano”. Artes La Revista, 4(8), 65 - 74. https://revistas.udea.edu.co/ index.php/artesudea/article/view/22980.

Jelin, E. (2002). Los trabajos de la memoria. Siglo XXI Editores.

Levinas, E. (1991). Ética e infinito. Visor Distribuciones S.A.

Malagón-Kurka, M. (2010). Arte como presencia indéxica. Ed. Uniandes.

Medina, A. (1999) El arte y la violencia bipartidista. Arte y violencia en Colombia desde 1948, Exh. cat., Bogotá, Colombia: Museo de Arte Moderno de Bogotá.

Pini, I. (1986). “Luis Ángel Rengifo, grabador”. En Escala/ I. I. E (Bogotá, Colombia), enero, 2- 13.

Puentes, J. (27 de agosto de 2018). "En el dolor es donde somos iguales", una charla con la artista Erika Diettes (entrada en blog). Semana Rural. https:// semanarural.com/web/articulo/entrevista-a-erika-diettes-sobre-su-obra-relicarios $/ 615$

Rancière, I. (2011) El malestar en la estética. Capital Intelectual.

Rancière, J. (2014). El reparto de lo sensible. Estética y política. Prometeo Libros.

Rancière, J. (2017). Et, al. La política de las imágenes. Ediciones Metales Pesados.

Richard, N. (2007). Fracturas de la memoria. Arte y pensamiento crítico. Siglo XXI.

Rubiano, E. (2018). "Duelo, memoria y dolor en la obra de Erika Diettes. AURA", en Revista de Historia y Teoría del Arte, 7, 83-108.

Rubiano, E. (2017). "Réquiem NN, de Juan Manuel Echavarría: entre lo evidente, lo sugestivo y lo reprimido.” En Cuadernos de Música, Artes Visuales y Artes Escénicas, Vol 12, (1), 33-45.

Uribe, M. V. (2008). “Mata, que Dios perdona. Gestos de humanización en mediode la inhumanidad que circunda a Colombia”, en Das V. Sujetos del dolor, agentes de dignidad. Universidad Nacional de Colombia, Pontificia Universidad Javeriana, Instituto Pensar. 


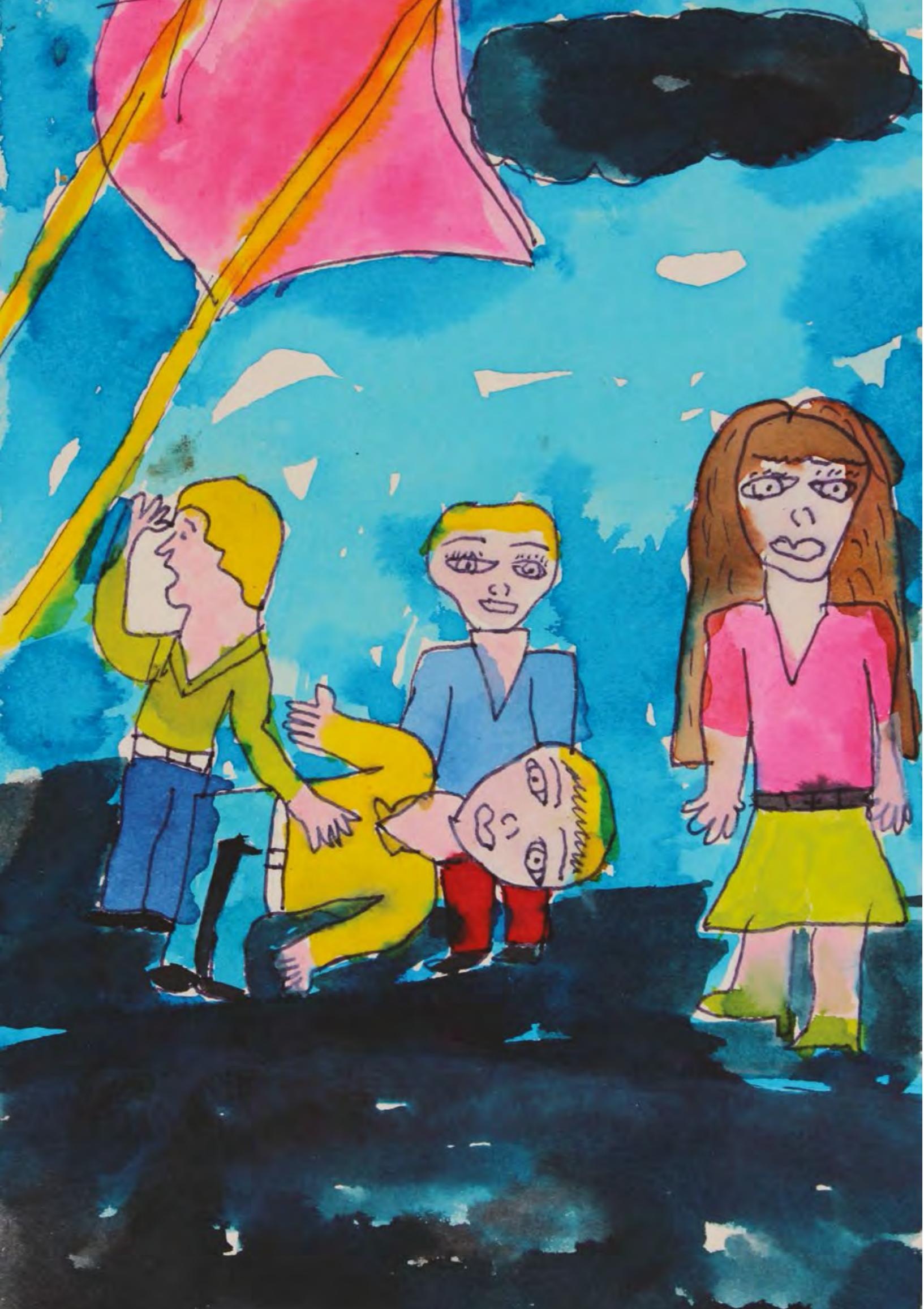

\section{Mediaciones estéticas}

Entre las precariedades sociales $y$

los flujos imaginativos de la expresividad estética

Margarita Calle 
El gran asunto de la estética contemporánea, su problemática central, es laorganización de lo múltiple: las relaciones predominan sobre los objetos, la arborescencia sobre los puntos, el pasaje sobre la presencia, el recorrido sobre las relaciones que lo componen. En contextos dinámicos, las formas tienden naturalmente a segregar relatos, empezando por el de su propia producción y continuando por el de su difusión: la obra tiende así a presentarse como una compleja estructura, susceptible de generar formas antes, durante y después de su realización.

N. Bourriaud (2015)

\section{Influjos de la estética}

La condición de inestabilidad que experimenta el arte desde hace más o menos dos décadas, pareciera reflejar los signos de una transformación todavía más radical que la presenciada hacia finales del siglo XX. La contundencia con la cual el campo del arte está abordando ciertos problemas de la sociedad, da pie para entender los sentidos que se juegan en tal transformación y el papel que las prácticas estéticas y artísticas están asumiendo como vía para cuestionar los problemas del presente y despejar el particular carácter de la época. Aunque desde el siglo XIX las vanguardias se empeñaron en detonar nuevos dominios para la creación visual y en el transcurso de siglo XX se construyeron los fundamentos para cuestionar, la materialidad de las creaciones artísticas, su condición de existencia y, sobre todo, su razón de ser, es en el presente donde parecen emerger con mayor determinación, algunas de las apuestas más directas para replantear el lugar del arte en relación con la biopolítica, la sociedad, la historia y la cultura. En tal emergencia se empieza a revelar "la singularidad es- tética” (Jameson, 2015, p. 115) ${ }^{1}$ de unas prácticas afianzadas en una lógica estrictamente relacional, interesadas por interrogar el presente y sus contextos, a partir de medios y narrativas que, a pesar de su naturaleza disímil y atemporal, se ponen en simultáneo, afectándose mutuamente. En esta condición espaciotemporal se comprometen unas formas inéditas de traducir - a la vez que transmitir- la experiencia de los grupos sociales y unos modos particulares de configurar sus "dispositivos de exposición" (Rancière, 2011, p. 32) o sus "formas de visibilidad y enunciabilidad" (Foucault, 2003, p. 86), que rompen con los modos ordinarios de experimentar los acontecimientos expresivos, para implicar reflexiones más amplias en relación con la vida social y política.

$\mathrm{Al}$ resistirse al impulso de traducir la realidad desde un determinado régimen regulador o desde una narrativa historizada, las prácticas estéticas y artísticas contemporáneas han conquistado la libertad para poner en obra sus propias "estrategias para producir acontecimientos" (Jameson, 2015, p. 119), ya no desde el dispositivo representacional, sino interpelando al testigo, reconstruyendo testimonios, recuperando archivos e instituyendo comunidades y espacios de participación, con y para las comunidades. En estos procesos se afianza una convergencia afectiva que podríamos equiparar con la noción de "fiesta", propuesta por Gadamer (2002, pp. 99-124), al hablar de la experiencia que posibilita el arte, sobre todo cuando reconocemos que tales colectividades activan espacios propicios para reencontrarse con los otros, en tiempos y un lugares atravesados por la vivencia, el recuerdo y la sintonía. Se trata de una idea genuina que da cuenta del sentido cultural de congregarse, de acabar con el efecto del aislamiento y, por esta vía, "celebrar" o rememorar algo que entraña sentido y experiencia compartida. Gadamer (2002) lo precisa de este modo: "Lo propio de la fiesta es una especie de retorno [...] el orden del tiempo se origina en la repetición de las fiestas" (p. 101), porque la fiesta,

1. Esta noción es introducida por el crítico cultural Frederic Jameson, para señalar el carác ter particular de unas prácticas estéticas y artísticas en las que asistimos a una desdiferenciación de las diversas artes y medios, a la volatilización del objeto de arte individual y a la desestructuración del propio sistema del arte que les servía de soporte. 
al igual que la posibilidad del arte, nos congrega (nos religa) y tal acción implica una actividad mediada por un acto intencional:

Celebramos al congregarnos por algo y esto se hace especialmente claro en el caso de la experiencia artística. No se trata solo de estar uno junto a otro como tal, sino de la intención que une a todos y les impide desintegrarse en diálogos sueltos o dispersarse en vivencias individuales. (Gadamer, 2002, p.101)

Ahora bien, en contextos de gran complejidad como los que ha generado la violencia política y el conflicto armado en Colombia, en especial los acontecimientos que tuvieron lugar entre 1982 y 2007, los cuales, según datos del Grupo de Memoria Histórica del Centro Nacional de Memoria Histórica (2008, p. 14) sumaron 2.505 masacres, con 14.660 víctimas, producto del accionar combinado del paramilitarismo, las guerrillas y la acción del Estado sobre las comunidades, los procesos de reconstrucción del tejido colectivo han encontrado en los dispositivos expresivos una estrategia cohesionadora, con capacidad para activar diferentes formas de mediación y participación colectiva. La manera como algunos artistas y creadores se acercan a los testigos de esta guerra y a quienes han vivido en carne propia la experiencia de la barbarie, ha dado lugar a espacios de intercambio y creación en los que, además de evidenciarse un nueva consideración sobre los presupuestos que dan lugar a la obra y al sentido de lo autoral, también se transita hacia un ejercicio transdisciplinar en el que la estética revela su potencia expansiva y cohesionadora.

En estos espacios los procesos de configuración se han dado desde dos apuestas particulares: la primera apuesta, propone la obra como espacio de visibilidad o de señalamiento para la resignificación de la memoria de las víctimas y la reconstrucción de una conciencia reflexiva del presente, mediada por el testimonio consensuado, el acceso a los archivos íntimos de los informantes, y la identificación de los rastros y de las huellas simbólicas y materiales de la tragedia. La segunda apuesta, se interesa por potenciar el sentido que adquieren las prácticas estéticas y artísticas para ciertos grupos sociales, la mayoría de las veces marginados de la atención del Estado, que han visto en ellas una posibilidad para volver a cohesionar los vínculos afectivos entre las personas, rotos por la acción de los vio- lentos y la fragmentación paulatina de sus comunidades de origen. Tales prácticas se han entendido, además, como un dispositivo oportuno para gestionar el drama de los propios victimarios, sometidos a complejos procesos de reintegración o normalización social.

En la primera perspectiva, es destacable el trabajo que desde la última década del siglo XX desarrollan artistas como Juan Manuel Echavarría, Doris Salcedo, Beatriz González, Erika Diettes, Clemencia Echeverry, José Alejandro Restrepo, Juan Fernando Herrán, el colectivo “Magdalenas por el Cauca" -Gabriel Posada y Yorlady Ruiz-, entre otros, que se han valido de esta condición para atestiguar y visibilizar, por mediación de lo poético y lo expresivo, otros testimonios, otras <<verdades >> inscritas en los acontecimientos, narradas por los propios protagonistas o por aquellos testigos que día a día buscan recursos para gestionar y acaso, aliviar la pérdida y el duelo² ${ }^{2}$ En la segunda perspectiva aquí enunciada, se

2. En relación con estas experiencias resulta significativo referenciar dos acercamientos iniciales al trabajo de algunos de los artistas abordados en este aparte, desarrollados desde el Grupo de Investigación Arte y Cultura y la Maestría en Estética y Creación de la Facultad de Bellas Artes y Humanidades de la Universidad Tecnológica de Pereira. El proyecto Gramáticas del recuerdo (septiembre de 2011), estructurado a partir de la exposición del proyecto Magdalenas por el Cauca del artista Gabriel Posada, en la Sala Carlos Drews Castro de Instituto de Cultura de Pereira; el performance La llorona de la artista Yorlady Ruiz, presentado en la sala Yves Klein de la Alianza Francesa de Pereira y la exposición Las madres del silencio, del fotógrafo Rodrigo Grajales, en la sala del Colombo Americano de Pereira todo esto en el contexto del proyecto cultural Corto Circuito, Escenarios para el Arte. Estas muestras estuvieron acompañadas de un espacio académico en el que, además, tuvo lugar la presentación de la película Los abrazos del río, del realizador Nicolás Rincón Gille (Catálogo disponible en: https://issuu.com/margcalle/docs/gramaticasdelrecuerdo). Asimismo, en mayo de 2015 se desarrolló el proyecto expositivo Indicios de la memoria, el cual reunió, en tres escenarios de Pereira, la obra de los artistas Erika Diettes, Juan Manuel Echavarrí y Gustavo Germano: la serie Río abajo de Erika Diettes se presentó en la Catedral Nuestra Señora de la Pobreza; la serie Silencios de Juan Manuel Echavarría, fue exhibida en la Sala Carlos Drews Castro del Instituto de Cultura de Pereira y la serie Ausencias del fotógrafo argentino Gustavo Germano, en el Museo de Arte de Pereira. Estas muestras propusieron un diálogo en torno a la manera como las prácticas artísticas abordan la construcción de narrativas sobre experiencias dramáticas como la desaparición y el desarraigo. A través de la fotografía, los tres artistas señalados desplegaron miradas poéticas para aventura formas de resignificación de las múltiples violencias de nuestro presente. (Catálogo disponible en: https://issuu.com/margcalle/docs/catalogo_indicios_de_la_memoria) 


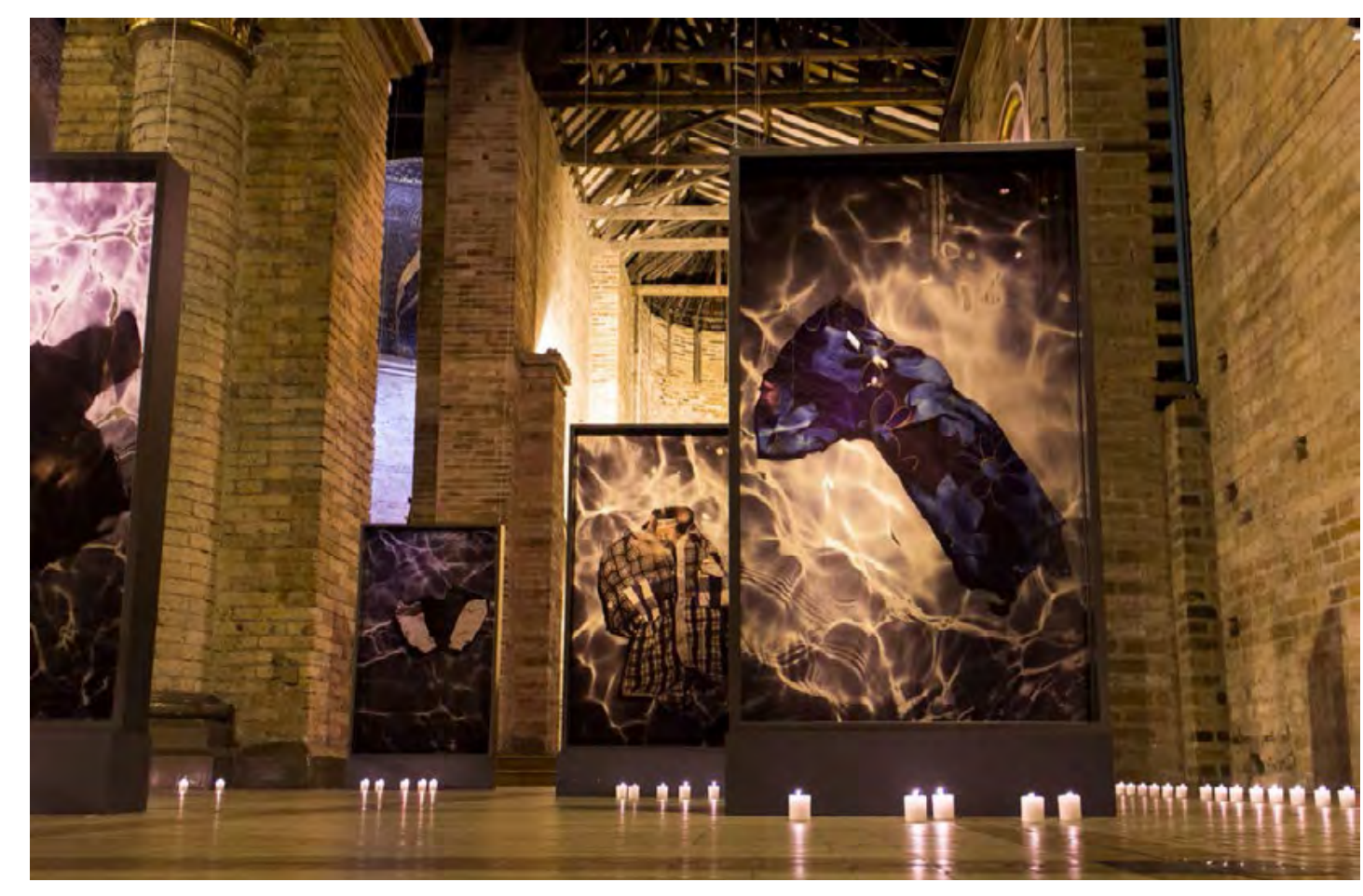

Exposición de la serie Río abajo de Erika Diettes en la Catedral Nuestra Señora de la Pobreza de Pereira, 2015

debe reconocer cómo los procesos expresivos se convierten en un recurso flexible y plural, clave para proyectar acciones tendientes a resignificar la memoria individual y colectiva, al recuperar simbólicamente el territorio arrebatado y reconstruir los relatos de la guerra, ya no desde la contingencia formateada por el relato oficial, sino desde la experiencia directa de las personas. En estos procesos la noción de comunidad juega un papel central, al concitar el sentido que entrañan los agrupamientos humanos, su relación con el espacio geográfico, las prácticas que los identifican, los hábitos y las relaciones con otros contextos del territorio.

No se trata, pues, de estrategias de mediación estética, desprovistas de condicionamientos espacio-temporales, de carácter social y político, sino más bien de procesos que emergen en los intersticios generados por la violencia, la exclusión, la incertidumbre y el desarraigo, lo cual fractura el vínculo comunitario y desliga a los grupos de su territorio. Por eso, estas intervenciones tienen lugar siempre con o en las comunidades y se configuran a partir de dispositivos de mediación, que reconocen en los lenguajes expresivos, la vía para desplegar procesos sociales, políticos y, por supuesto, afectivos. En ellas la labor configuradora desborda el interés por señalar un acontecimiento artístico específico desde un determinado formato o narrativa, para privilegiar aquellos momentos de reflexividad e intercambio en los que afloran imágenes y relatos insurgentes, suspendidos en una memoria que busca el soporte adecuado para su exteriorización.

En estas apuestas, las acciones tienen lugar, bien sea por iniciativa de un artista o un colectivo de artistas que decide trabajar colaborativamente con un grupo o una comunidad, o bien a partir de procesos de intervención social, direccionados desde un programa estatal o por una iniciativa institucional, con miras a activar lo que Nelly Richard (2017) denomina "las mallas de significación" (p. 141) de una memoria abierta, inconclusa en su relato. Un tejido significativo que reclama formas inéditas de interpelación para poner en relación pasado en el presente.

En este contexto destacamos el proyecto La guerra que no hemos visto, desarrollado por el artista Juan Manuel Echavarría, con el apoyo de integrantes de la Fundación Puntos de Encuentro, en el que participaron actores del conflicto armado vinculados a los diferentes grupos en confrontación: excombatientes de la guerrilla de las Farc, exintegrantes de las Autodefensas (AUC) y exsoldados del ejército colombiano, heridos en combate. Asimismo, aludimos a los proyectos desarrollados por el colectivo “Magdalenas por el Cauca”, conformado desde 2008 por los artistas Gabriel Posada y Yorlady Ruiz, con participación de asociaciones de víctimas de la masacre de Trujillo (Valle del Cauca) y miembros de las comunidades ubicadas en la zona ribereña del río Cauca, en el norte del Valle del Cauca y Risaralda.

Todas estas experiencias se caracterizan por señalar un espacio dislocado para el hacer del artista, que implica un desplazamiento del lugar de privilegio autoral en el que estaba acostumbrado a crear. Además de comprometer una experiencia relacional, el artista arriesga posturas políticas, orientaciones pedagógicas y sistemas de participación, cuyo foco de interés, si bien no margina el contenido de la obra, sí le confiere otra dimensión a su sentido, en términos históricos y contextuales. De hecho, muchas de las creaciones responden a ejercicios colaborativos en los que el artista actúa como facilitador o mediador de los procesos, al margen de 
cualquier certeza sobre la posibilidad del resultado, siendo las latencias propias de la acción participativa, los desencuentros, las interrupciones y las discontinuidades, las condiciones que esbozan el tránsito de los proyectos asumidos en esta perspectiva.

La herramienta más potente de estas apuestas consiste en favorecer el despliegue del obrar del arte, su capacidad religante (pragmática en el pleno sentido del término), para que actúe como vínculo de relación o posibilidad de vínculo afectivo entre comunidades, grupos y creativos. Se busca que, desde la provocación de lo expresivo y sus recursos estéticos y culturales (transmitidos a través de talleres o laboratorios de creación), los participantes activen su memoria, narren su experiencia y se reconozcan como agentes en el devenir de una realidad, bien sea como víctimas o victimarios; por esta vía, al convertirse en protagonistas de su propio relato, testimonian su papel en el devenir de una historia que reclama unas "maneras otras" de interlocución con los hechos y su impacto.

Todas estas condiciones tienen un marcado carácter político, en tanto obligan a un descentramiento del lugar que la institución le ha conferido al artista, especialmente en el horizonte promisorio construido desde las vanguardias, para exhibir, como precisa Rancière (2011), una función del arte que consiste en "construir espacios y relaciones para configurar material y simbólicamente el territorio de lo común” (p. 31). Se trataría, pues, de una condición que empuja los procesos creativos hacia una "desespecificación de los instrumentos, materiales o dispositivos propios” (pp. 3132), que atraviesa todo el plexo de las prácticas estético-artísticas; lo cual permite que estos procesos ocupen lugares inéditos y construyan sentido en torno de nuevas relaciones afectivas "entre los cuerpos, las imágenes, los espacios y los tiempos" (p. 32).

Por su parte, cuando los procesos de mediación se desprenden de programas de intervención social, agenciados por el Estado o alguna organización civil que actúa en nombre de este, el obrar de las prácticas estético-artísticas se desplaza a un espacio de interlocución más poroso e inclusive más plural, en función de situaciones y acontecimientos que encuentran en las materialidades y en los recursos expresivos una posibilidad para resignificar, a la vez que de transmitir la experiencia vivida.
Desde estas premisas, las intervenciones creativas que comprometen comunidades y colectivos sociales buscan agenciar procesos de participación e intercambio, en los que, al margen de la calidad de las producciones, el interés se focaliza en los comportamientos, las activaciones, los modos de relacionamiento y los vínculos de cohesión que propician estas prácticas expresivas.

En el contexto del proyecto Mediaciones estéticas y expresividades de la memoria, este aparte busca desplegar el sentido de las apuestas aquí señaladas, abordando las dos estrategias de mediación situadas arriba, con miras a sustentar una particular condición del obrar de las prácticas estético-artísticas en el presente. Ambas sacan a flote, por lo menos, tres lógicas de despliegue, claves en el proceso de transición que vive Colombia, en relación con la implementación de los Acuerdos de Paz firmados en 2016: a) el interés por reterritorializar los espacios de las prácticas estético-artísticas y expandir los límites de sus funciones tradicionales; $b$ ) la voluntad de intervenir y movilizar actitudes y comportamientos en comunidades y grupos sociales que escasamente han tenido un acercamiento al horizonte de visualidades que recrea el arte; y c) la afirmación de unas prácticas eminentemente relacionales, que más que apelar a un consenso social o estético, afirman el lugar de un disenso expresivo que se manifiesta como postura ética, acción política y práctica social.

Desde experiencias singulares como los encuentros cotidianos, la conversación, la práctica de la pintura, el tejido, el bordado, la creación artesanal, el intercambio de vivencias o la transmisión de saberes, las colectividades que han padecido las atrocidades de las violencias recientes, reconocen en estas apuestas una potencia religante, especialmente afectiva, que al lado de otras acciones de visibilización, reconstrucción de memoria y restauración de derechos, contribuyen a cohesionar los vínculos rotos de sus comunidades, a causa de la intervención disruptiva de agentes externos violentos. La posibilidad de narrar los hechos, encarnarlos en sus cuerpos o materializarlos en imágenes y espacios de participación, activa contextos de expresividad en los que convergen relaciones con lo sensible, a partir de la mediación entre lo simbólico y lo material, lo estético y lo político, lo relacional y lo comunitario. 
También, por esta vía, las colectividades tramitan las afecciones derivadas del desarraigo, del duelo inconcluso, de la ausencia, de la pérdida o del despojo, como reacción ante la falta de unos procesos efectivos de justicia restaurativa, en los que además de esclarecer los hechos, se repare el daño causado a las víctimas.

Aunque es claro que las acciones emprendidas por las colectividades no sustituyen el papel que le corresponde asumir al sistema judicial y al Estado frente a la reparación, es importante reconocer el valor y el efecto cohesionador que tienen los dispositivos y las acciones expresivas en la tarea de visibilizar, interpelar y testimoniar la contundencia de los acontecimientos ocurridos, desde la singularidad de la experiencia vivida, del lugar de enunciación asumido y del relato que lo refrenda. Tampoco se trata, como ya lo analiza en el primer capítulo de este libro el investigador Martínez, de "estetizar la violencia" o de proponer imágenes que ilustren la historia y sumen registros a su relato inconcluso. El propósito es, más bien, inscribir un «gesto otro» que, como advierte Bourriaud (2015), dé cuenta de

"un posicionamiento" de los actores comprometidos frente a ella y contribuyan a sumar miradas, cuya lectura aporte a una comprensión del sentimiento de indignación, desacuerdo o desequilibrio generado por los acontecimientos de la barbarie, al tiempo que se declara su impunidad y su petrificación en la memoria colectiva. (p. 55)

Ante la saturación de imágenes derivadas del conflicto armado colombiano y su banalización cotidiana, producto de las fuerzas en tensión que se disputan su legitimidad semántica y discursiva, resulta imperioso detener la mirada en los procesos expresivos que comprometen la acción de tantas colectividades concernidas con estos acontecimientos, para reflexionar, o si se quiere, recabar en la manera como se pone en juego la función moduladora y religante que cumplen los lenguajes simbólicos y expresivos en estas transiciones políticas. En la perspectiva de Badiou (2003), se apuntaría a potenciar un campo de indagación en el que las creaciones materiales afianzadas en lo "acontecimental", se conviertan en posibilidad de anclaje para el despliegue de un relato no clausurado, dado que no responden propiamente a una verdad objetiva, sino a un tipo de registro axiomático, que inscribe su propio régimen de verdad y, en consecuencia, se distancia de cualquier régimen existente.

Se trata, en suma, de reconocer, como también lo advierte Rancière (2009), "el lugar y la problemática de la política como forma de la experiencia" (p. 10); de comprender cómo se opera un nuevo "reparto de lo sensible" en el espacio social, en el que parecen desplazarse las competencias para ver, hacer y decir, sin la sujeción a un determinado régimen de legitimidad, frente al dominio de los lenguajes y discursos expresivos. Si bien, como precisa este autor "la política trata de lo que vemos y lo que podemos decir al respecto, sobre quién tiene la competencia para ver y la cualidad para decir, sobre las propiedades de los espacios y los posibles del tiempo" (p.10), es viable valorar y cuestionar la manera como se están materializando ciertas experiencias de apropiación y desregulación de tales dominios, por acción de actores sociales y culturales, que han encontrado en las prácticas estético-artísticas un dispositivo de mediación propicio para afrontar las demandas de este singular presente.

Las experiencias a las que hacemos alusión en este acercamiento trazan, entonces, unas rutas posibles para entender cómo las prácticas estético-artísticas, y de manera particular aquellas surgidas en el fragor de los conflictos de la violencia política en Colombia, que han dominado los territorios en las tres últimas décadas, se han ocupado de reinscribir los registros de múltiples experiencias colectivas, muchas de ellas silenciadas o menguadas por los discursos oficiales y por los actores responsables de romper el nexo constitutivo de algunas comunidades.

Se trataría de un primer aporte a la posibilidad de sumar imágenes y experiencias que contribuyan a configurar una "arqueología del presente" (Bourriaud, 2015), enteramente transmisible, configurada por testimonios y residuos de registros materiales, que por su carácter experiencial y acontecimental devienen memoria colectiva o sistema de referencias interindividual en un espacio-tiempo particular. Cada una de estas experiencias da cuenta de un acontecimiento singular, cuyo valor se define, tanto por la red de significados presupuestados para su materialización, como por aquellos deslindes suscitados en su realización. 


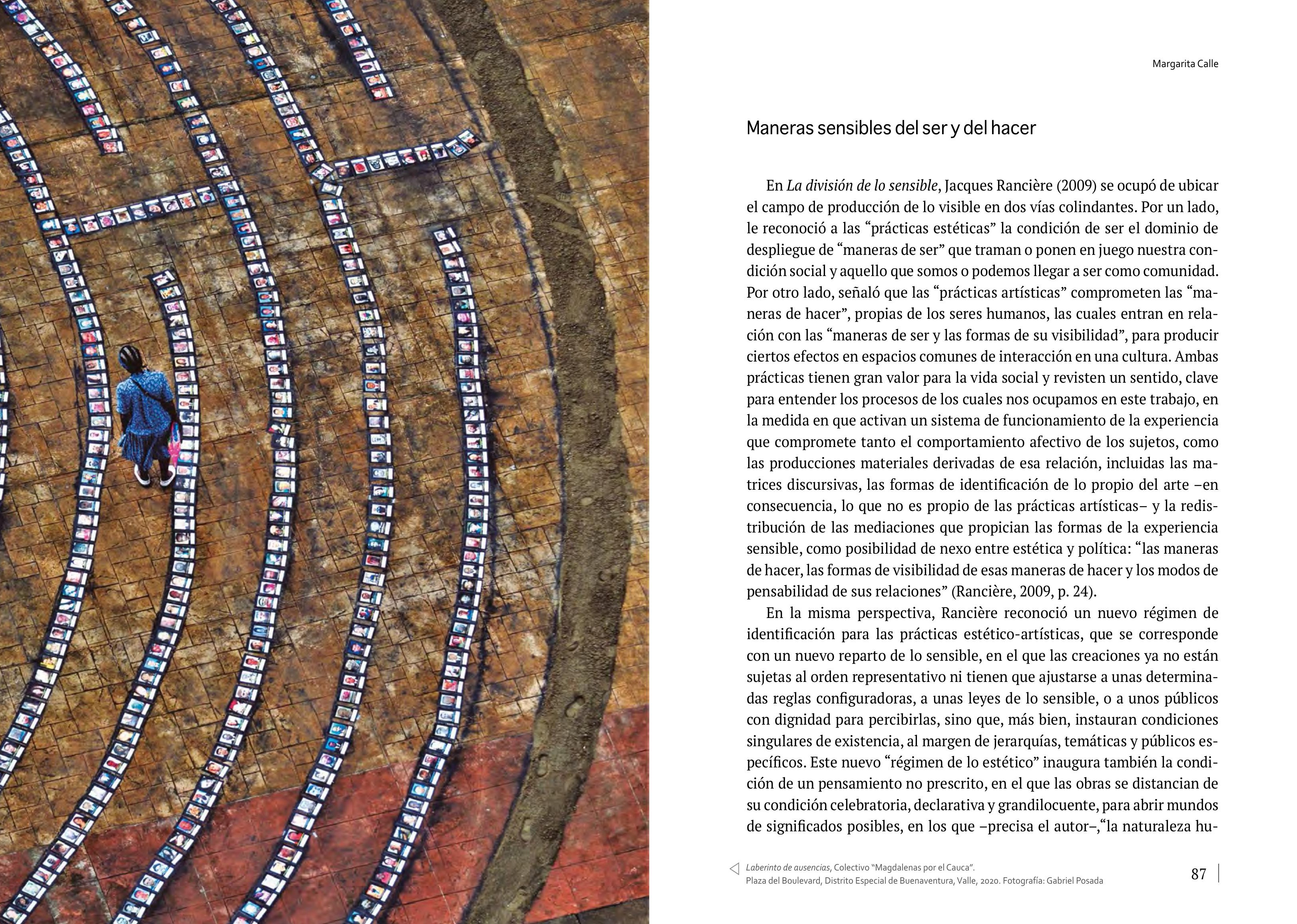




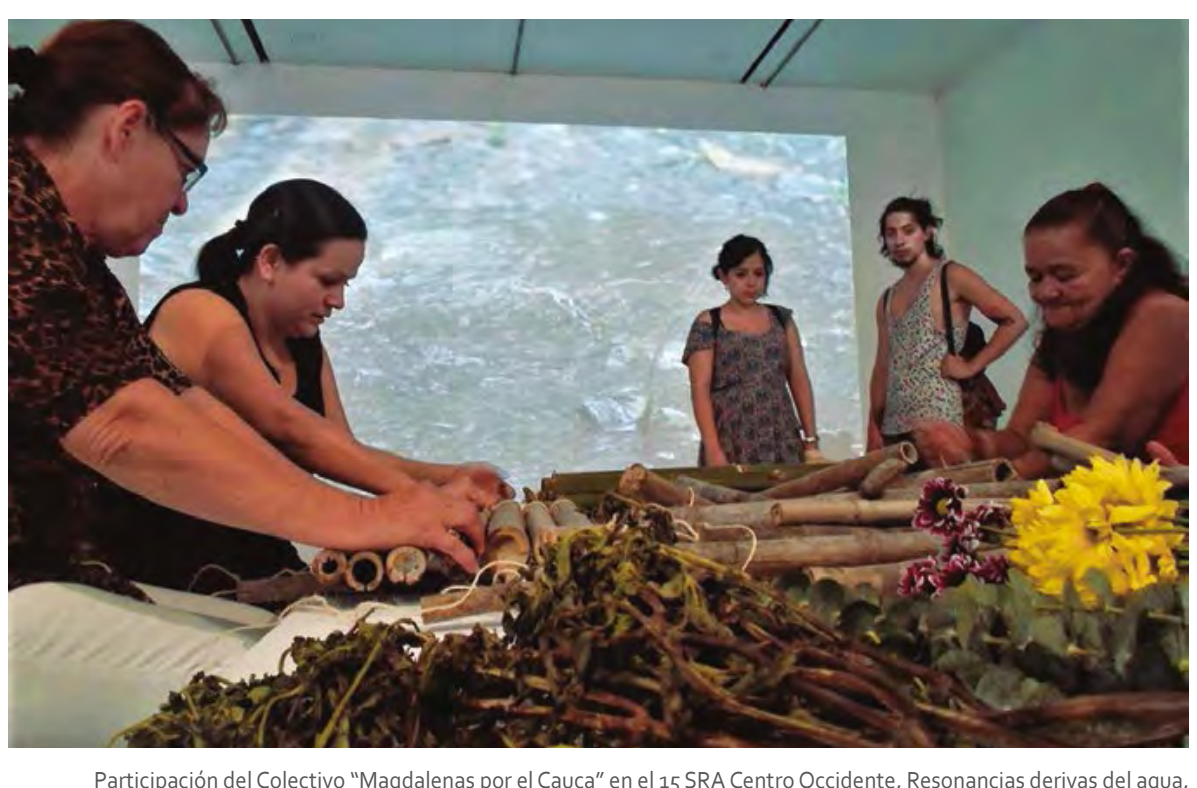

"Magdalenas por el Cauca" en el 15 SRA Centro Occidente, Resonancias derivas del agua,
Museo de Antioquia, 2015. Curaduría Luis Fernando Arango. Fotografía: Gabriel Posada

mana y la naturaleza social dejan de garantizarse mutuamente. La actividad de fabricar y la emoción sensible se reencuentran «libremente», como dos fragmentos de una naturaleza que ya no es reflejo de ninguna jerarquía de la inteligencia activa sobre la pasividad sensible." (Rancière, 2009, p. 24) En consecuencia, se rompe con ese reparto de lo sensible que hacía concordar obras con sensibilidades, artistas con posturas prefijadas y públicos con gustos determinados, para animar un campo de experiencias disruptivas en el que las creaciones se instalan como gestos que ponen a circular sentidos y se ofrecen a la mirada de cualquiera.

En estas consideraciones, la comprensión de la estética y lo estético se expanden, superando los marcos de entendimiento tradicionales, o como señala Rancière, "las formas ordinarias de la experiencia sensible" (2001, p. 33), para desentrañar conductas, comportamientos y situaciones en las que aparece comprometida la condición política, cultural y ontológica del sujeto.

En consecuencia, las creaciones estético-artísticas no solo devienen dispositivo de mediación y traducción de experiencias, sino también soporte de inscripciones, conductas y acontecimientos que comprometen una relación más empática y considerada con los otros: aquellos en quienes se reelabora el sujeto de la memoria, de la identidad, del territorio, de

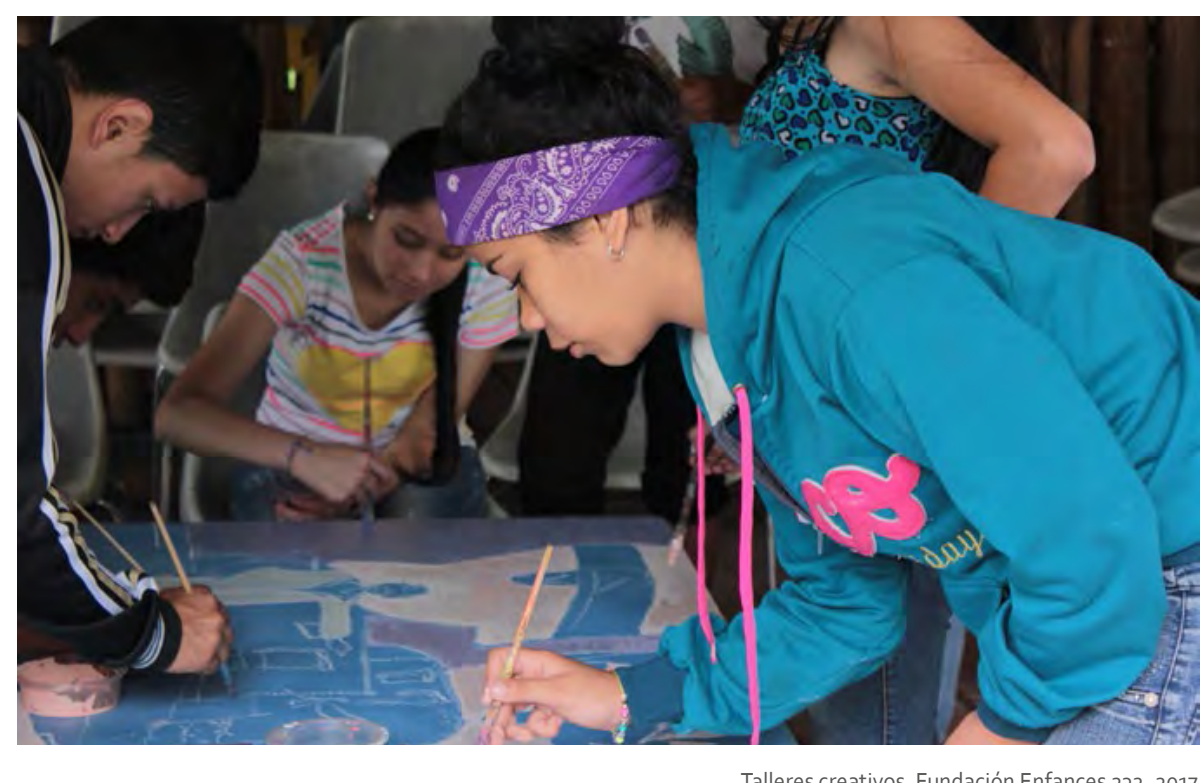

Talleres creativos, Fundación Enfances 232. 2017

los lugares, del dolor, de la ausencia, del abuso, de las narraciones y las narrativas dislocadas de nuestro tiempo. Aquellos, quienes, a pesar de haber experimentado el despojo, conservan la legitimidad simbólica del relato, encarnado en sus afectos, sus memorias, expresividades y recuerdos.

Conversar, pintar, dibujar, tejer, coser, esculpir, escribir, cantar, cultivar, cocinar, recortar, pegar, caminar, exponer o intervenir el cuerpo, entre muchas otras acciones cotidianas, se han convertido en verdaderos dispositivos de enunciación y exhibición en los que, al margen de los valores plásticos o artísticos configurados, es posible rescatar el carácter mediador y, por ende, político, modulador y religante, desplegado en los contextos donde tales procesos tienen lugar y cobran sentido.

Signados por las marcas que ha dejado el conflicto armado en los territorios, las víctimas se han interesado por recuperar aquellas experiencias que le dan vitalidad al recuerdo, para fijarlas en nuevos soportes, a partir de otras trazas e inscripciones que hagan posible su actualización. Si bien, como lo advierte Nelly Richard (2015, p. 156), la huella es "la traza misma (inscrita, grabada) que registra la memoria", no debemos olvidar que este tipo de experiencias condensan también, o sobre todo, "el potencial de reanimación del pasado depositado en esta reserva que se mantiene disponible para cualquier futura aparición del recuerdo" (p. xxx). 
Las experiencias expresivas de las cuales se ha ocupado este proyecto, sumadas a otros ejercicios desarrollados por Margarita Malagón (2010), lleana Diéguez (2013), María del Rosario Acosta López (2016), desde el grupo de investigación Ley y Violencia de la Universidad de los Andes, y Elkin Rubiano (2018 - 2019), nos han permitido constatar que en Colombia los procesos de reconstrucción de la memoria histórica, en el marco del conflicto, han logrado mayor impulso por fuera del ámbito institucional.

La labor de algunos artistas en contextos afectados por acciones violentas, ha dado lugar a proyectos de gran incidencia estética, política y social, no solo por otorgarle voz a personas que históricamente han sido silenciadas, sino, fundamentalmente, por afianzar una estrategia productora de acontecimientos estéticos y dispositivos para la exteriorización de la experiencia vivida, capaces, como lo precisa Elkin Rubiano, de "activar el habla de los participantes, en un contexto donde el mandato ha sido callar" (Rubiano 2018, p. 81). Al respecto señala Rubiano:

En las prácticas artísticas concentradas en los territorios del conflicto armado, las víctimas dejaron de ser una noción lejana construida mediante recursos visuales rutinarios y tradicionales, es decir, mediante fórmulas que hasta algún momento resultaron eficaces en el campo del arte colombiano. La representación de los desastres de la guerra mediante los recursos de la expresividad, la fealdad y la fragmentación de los cuerpos, fueron cediendo para darle lugar, en nuestro contexto, a otras apuestas en las que en lugar de la representación de la víctima se dan formas de activación del habla de los individuos y las colectividades. (p. 70)

Este tipo de prácticas, como ya se señaló, materializan el tránsito de unos procesos expresivos afianzados en la figura del artista-creador, en el sentido tradicional del término, hacia unas prácticas que privilegian lo relacional y la condición religante del arte, como estrategia de descentramiento y apertura, para poner a prueba la eficacia de estos dispositivos en contextos donde se busca ampliar las posibilidades de participación de los públicos, el sentido de lo político como relación y la capacidad de los procesos expresivos que sirven para testimoniar o dar cuenta de los acontecimientos, a contrapelo de realidades históricas vigiladas y controladas. En relación con este horizonte de intervención de las prácticas estéticas y artísticas, a continuación haremos alusión a tres proyectos creativos, cuya incidencia en los procesos de resignificación de la memoria colectiva del conflicto armado de Colombia, ha ido delineando nuevas trayectorias y posibilidades de sentido: La guerra que no hemos visto, del artista Juan Manuel Echavarría, Magdalenas por el Cauca y 327 alumbramientos por las huellas del olvido de Gabriel Posada y Yorlady Ruiz, integrantes del colectivo "Magdalenas por el Cauca".

\section{La guerra que no hemos visto}

Entre 2007 y 2009, el artista Juan Manuel Echavarría se comprometió con el desarrollo de un proyecto plástico de carácter colectivo, en el que participaron 120 hombres y mujeres, que en diferentes circunstancias estuvieron vinculados al conflicto armado del país, bien como integrantes de grupos guerrilleros, bien como paramilitares, o bien como miembros de las fuerzas armadas del Estado: excombatientes de las Autodefensas Unidas de Colombia (AUC), de las Fuerzas Armadas Revolucionarias de Colombia (FARC-EP) y el Ejército de Liberación Nacional (ELN); soldados heridos en combate del Batallón de Sanidad del Ejército y Mujeres desmovilizadas de las FARC-EP. En compañía de los artistas Fernando Grisalez y Noel Palacios, con el apoyo de la Fundación Puntos de Encuentro, el equipo realizó una serie de talleres de pintura y ejercicios de creación en los que animaron a los participantes a narrar visualmente, desde sus propias vivencias, la experiencia de la guerra.

Durante los dos años que duró el desarrollo del proyecto, cada grupo de excombatientes logró plasmar en retablos de $35 \times 50 \mathrm{~cm}$., que luego eran ensamblados, sus memorias como actores de la barbarie, como usurpadores y usurpados, como protagonistas o testigos de una de las manifestaciones de crueldad más feroces y devastadoras de la violencia reciente en Colombia.

De acuerdo con Echavarría, "los excombatientes plantearon la pintura como testigo, como pieza de memoria, como un nuevo espacio que albergaba un sin fin de historias entrelazadas entre sí". (https://aguerraqueno- 


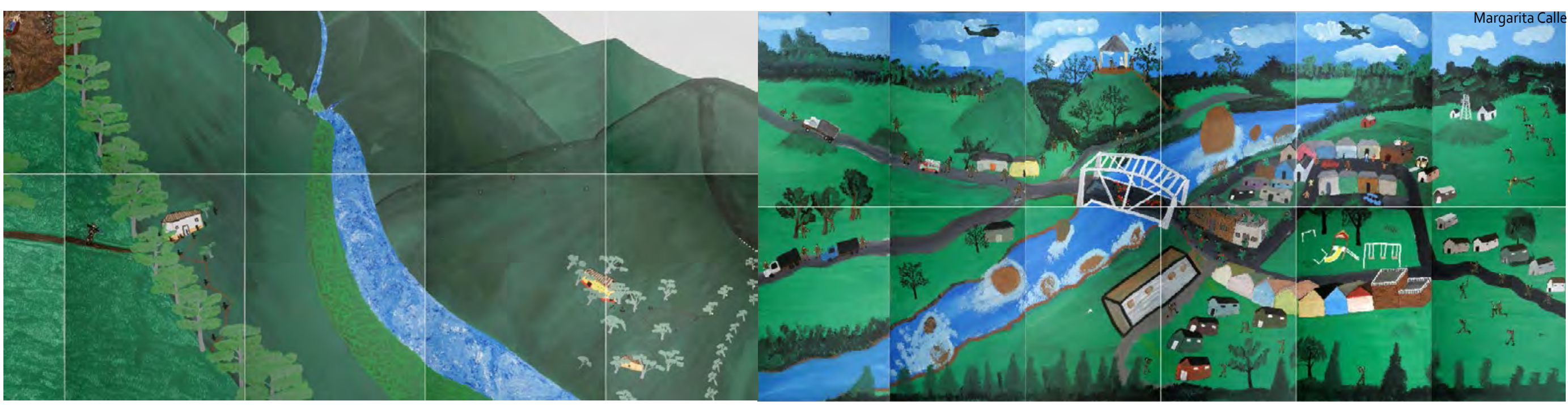

hemosvisto.com/es/info/). Ninguna de las historias respondía a un relato lineal ni completo; eran relatos fragmentarios, episódicos, en los que si bien se evidenciaban todas las connotaciones de una experiencia íntima, personal, era posible reconocer, a su vez, el agenciamiento de una acción colectivamente legitimada.

Más allá de los aspectos básicos relacionados con los formatos, los soportes y los materiales, las intervenciones fueron realizadas de manera voluntaria, sin que mediara una preocupación particular por el modo como cada uno debía configurar el relato, o sobre los aspectos técnicos o formales de las pinturas. Más que el resultado plástico, les interesaba propiciar un espacio afectivo que animara el diálogo, como posibilidad para el desplazamiento comprensivo; de suerte que pudiera "narrarse" la experiencia, para poner en imágenes y en palabras lo que cada uno estaba dispuesto a compartir sobre su lugar en la guerra, bien como testigos, como actores o bien como testimoniantes. Una oportunidad de apertura que contrasta con el interés de algunas agencias del Estado por silenciar las voces y los testimonios de muchos de los protagonistas de la barbarie, en tanto estrategia amnésica para concitar el olvido de una guerra que muchos de nosotros, en especial los habitantes citadinos, no hemos vivido.

El resultado de este proyecto lo integran 480 pinturas de gran formato. Pinturas pletóricas de gestos, relatos, afecciones y marcas expresivas, en las que se destaca el carácter realista y sincero con el que los creadores asumieron este ejercicio. $\mathrm{El}$ archivo del proyecto ${ }^{3}$, clasifica las pinturas en cuatro grupos: FARC-EP mujeres - FARC-EP hombres, AUC y Ejército. A su vez, cada grupo de participantes configura su narración a partir de un glosario de categorías a través de las cuales se nombran acciones realizadas, intenciones, condiciones de vida y contextos.

El grupo de pinturas de las AUC recoge trabajos que se agrupan en las categorías: Desaparición, Ejecución, Iniciación en la guerra, Tortura, Venganza, Combate, Toma a población civil, Secuestro, Violación, Entierro-fosas, Autorretrato, Deserción, Mutilación, Narcotráfico, Venganza. En esta misma línea, las pinturas realizadas por soldados del ejército se organizan en las categorías: Minas antipersonal, Combate, Narcotráfico, Velorio, Desaparición, Ejecución, Venganza, Control territorial, Autorretrato, Masacre, Mutilación, Tortura, Violación, Campamento. Mientras que el grupo integrado por excombatientes de las FARC-EP, dibuja su relato en torno a categorías como: Control territorial, Autorretrato, Velorio, Campamento, Falsos positivos, Combate, Narcotráfico, Ejecución, Entierro-fosas, Mutilación, Tortura, Venganza, Masacre, Consejo de guerra, Desaparición,

3. El archivo del proyecto La guerra que no hemos visto, puede ser consultado en el sitio web: https://laguerraquenohemosvisto.com/es/ 
Ejecución, Deserción. En las experiencias de las mujeres excombatientes de las FARC-EP, se repiten estas categorías, al lado de otras, como: Violación, Aborto, Velorio, Deserción y Toma a población civil. Adicionalmente, también es posible recorrer el archivo a partir de tres grandes categorías: ejecución, tortura y narcotráfico, cuya connotación permite dimensionar el orden de los contenidos creados y narrados por los participantes.

La redundancia que generan todas estas nociones contribuye a crear una codificación de comportamientos y acciones que se replican de manera incesante entre los diferentes actores del proyecto, al configurar así los rasgos indiciales de unos hechos amplificados y encarnados en el tiempo de nuestra historia reciente y convulsa.

Al explorar el archivo se evidencia, en primera instancia, el diálogo que estimula el artista Juan Manuel Echavarría en torno a la experiencia derivada de este proyecto. Allí se constata el carácter expresivo, íntimo y gestual de cada imagen y la manera como el dispositivo de la pintura, en tanto sistema de inscripción mnemónico, da lugar a una sucesión de formaciones inéditas en las que se desentraña la capacidad del sujeto para traducir su experiencia y patentizarla en gestos sensibles. Una experiencia que actúa como detonador de memorias ancladas en convicciones, comportamientos, reconocimientos y contradiciones, para la cual, si nos apoyamos en Jean-Luc Nancy (2014), “ninguna forma previa está dada” (p. 17), más allá de la propia acción como protagonista o testigo de los hechos.

También, cuando el equipo de investigación de este proyecto participó de algunos espacios de diálogo con Juan Manuel Echavarría, fue posible identificar el valor que este le reconoce al modo de narrar de los participantes, la capacidad de patentizar lo transmisible y atestiguar para el espectador la experiencia de una guerra que, a pesar de todas las historias relatadas, continúa siendo ajena para muchos. Justo esa posibilidad de apertura o de "activación del habla de los participantes" (Rubiano 2018, p. 81), abre una condición de legibilidad que afianza, en quienes observan las imágenes, el impacto y la eficacia de sus contenidos.

En relación con este carácter testimonial y configurador de las piezas de La guerra que no hemos visto, la curadora Ana Tirsconia señala:
Al espectador que se vea confrontado con estas pinturas se le hará evidente que estos testimonios no hubieran sido posibles sin la intermediación del arte; que fueron las características del lenguaje plástico y el uso de las herramientas de representación los que habilitaron mucho de lo dicho. Incluso la falta de un entrenamiento profesional contribuyó en este caso. El uso aleatorio de códigos visuales permitió simbolizar lo que se quiso decir y también lo que se dijo sin querer. (Tirsconia, s/f)

Es justamente ese carácter ingenuo, casi infantil de la pintura y esa singularidad compositiva de cada pieza, lo que, en lugar de restarle valor plástico al trabajo de los participantes, le suma sentido y sinceridad, permitiéndoles hablar desde una narrativa de la recordación, que se afianza en la experiencia de un espacio-tiempo propio, al cual -colegimos- no habían tenido acceso por otros medios o por otros canales de comunicación. Y no habían tenido acceso, porque a lo largo de la historia del conflicto armado en Colombia el silenciamiento de las voces, de los que tienen algo que decir o expresar, se ha extendido por el territorio, convirtiéndose, además, en estrategia de supervivencia para muchas personas.

Observar este proyecto de Juan Manuel Echavarría, situado en el campo de fuerzas que entran en tensión en el conflicto armado colombiano, consigue dimensionar su efecto disruptor, en términos expresivos y contextuales; no tanto por abordar la violencia en términos de un campo de reflexión, como por insistir en ampliar la lectura de estos fenómenos; de suerte que logra involucrar en una misma convergencia, cuerpos, acciones, voces, intercambios y movimientos, en los que, como señala Rancière, se despliegan las posibilidades que tiene la creación artística, al romper con el régimen jerárquico de la representación.

Hemos planteado que la iniciativa de este trabajo colaborativo no se propuso sintonizar o equiparar en un mismo escenario los relatos y miradas de grupos tan divergentes, como lo pueden ser los desmovilizados del paramilitarismo, los excombatientes de la guerrilla y los efectivos del ejército colombiano. Es significativo, eso sí, que una acción creativa logre “activar la voz” (Rubiano, 2017) de grupos tan disímiles para que, desde sus oposiciones ideológicas y pragmáticas, den cuenta de lo acontecido y lo materialicen en gestos, en posibilidades de sentido. Desde su lugar 
de enunciación, cada participante del proyecto aporta señas y suma indicios para contribuir a la reconfiguración de un nuevo mapeo de nuestros territorios. ¿Se trata acaso de un nuevo mapa, de una nueva cartografía sensible? Sin duda sí; se trata de un mapa hecho de residuos, de historias fragmentadas, de emociones divergentes, de dilemas éticos, de imágenes plenas de referencias y evocaciones que, como lo advierte Ana Tiscornia, interrogan los límites de la palabra a la hora de conjurar esa verdad inasible, resultado de un contexto en crisis, donde aún es posible sentir el dolor y la angustia de la pérdida, pero donde también es factible conjurar el olvido.

\section{Magdalenas por el Cauca}

Pensemos ahora en el proyecto Magdalenas por el Cauca, del cual se presenta un primer acercamiento en el capítulo 1 de este trabajo. Recordemos que este proyecto surge en 2008 por iniciativa del artista Gabriel Posada, con el acompañamiento de la artista Yorlady Ruiz. La iniciativa parte de reconocer que en Colombia los ríos han sido utilizados como fosas comunes para borrar la huella de los cientos de desaparecidos que han sido arrojados a sus aguas por circunstancias disímiles. Particularmente, el río Cauca, con su abundante caudal, se ha convertido en símbolo de desaparición, de ausencia, de dolor y, sobre todo, de búsqueda y espera: durante años muchas madres colombianas han hurgado su cauce, esperando hallar, sin certeza alguna, el cuerpo de sus hijos, esposos o parientes desaparecidos.

El interés de estos artistas por abordar prácticas artísticas de carácter relacional con comunidades directamente afectadas por la violencia política no es reciente. El recrudecimiento de la violencia política que tuvo lugar en las dos últimas décadas del presente siglo, en los territorios de Risaralda y Norte del Valle, especialmente en municipios como Trujillo, Cartago, Marsella, Beltrán y La Virginia, fue el detonante de una serie de proyectos creativos que asumieron como forma de configuración el trabajo colaborativo y la movilización política, para propiciar en cada contexto escenarios de mediación y resignificación de la memoria colectiva.

El proyecto Magdalenas por el Cauca ha sido el de mayor impacto y duración. Al momento del cierre de esta investigación ya completaba 12 años sumando acciones y gestos expresivos a la construcción de una narrativa de la memoria que, por el carácter recurrente de los hechos que movilizan los fenómenos de la violencia en el territorio colombiano, todavía dista mucho de terminar.

Así, a partir de esta iniciativa se articulan una serie de proyectos y puestas en obra in situ, que comprenden recorridos, instalaciones, performances, murales, conferencias, acciones colectivas, proyectos audiovisuales y gestos rituales, los cuales, además de ser eficaces en términos simbólicos, han contribuido a cohesionar a las comunidades de los territorios señalados, animándolas a desplegar procesos de resistencia frente a una guerra que parece no menguar en el propósito de intimidarlos y desplazarlos. A partir de talleres artísticos y ejercicios creativos con personas de la comunidad, este colectivo de artistas se ha empeñado en señalar cómo desde la reflexividad y el trabajo laborioso de las prácticas estético-artísticas es posible contribuir a movilizar procesos de resignificación de la memoria en la dinámica de unas colectividades que, por años, han vivido amedrentadas por acción de las diferentes fuerzas en conflicto (guerrillas, paramilitares y bandas criminales), con la permisividad directa o soterrada del Estado.

Como ya lo señaló el investigador Felipe Martínez en el capítulo 1 de esta investigación, el proyecto fue concebido en el contexto de una residencia artística otorgada por el Ministerio de Cultura de Colombia al artista Gabriel Posada, en concertación con la Asociación de Familiares de Víctimas de Trujillo (AFAVIT) y varias organizaciones más del municipio de Trujillo (Valle del Cauca). Su creación contó con la dirección artística de Yorlady Ruiz y el apoyo del fotógrafo Rodrigo Grajales, quien realizó el registro de todo el proceso comunitario y performático.

De acuerdo con Yorlady Ruiz (2018), "la obra lleva implícito el nombre de María Magdalena, a partir del cual se configura la piel y el grito de nuestras mujeres, en un acto mediado, inicialmente por los recuerdos personales del artista Gabriel Posada, los cuales sirvieron de contrapunto para 

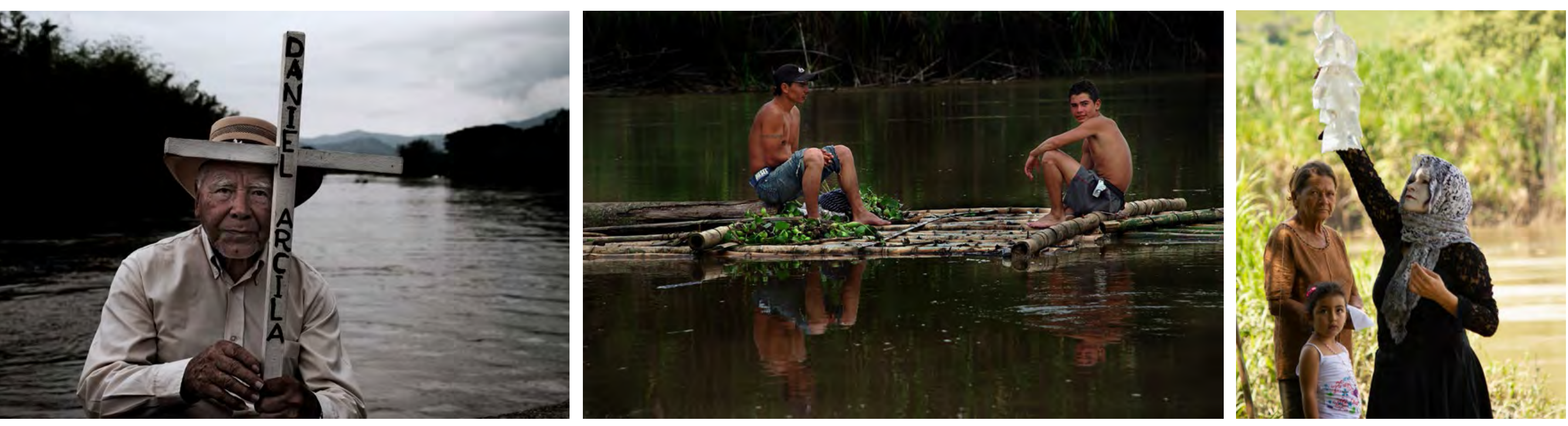

construir el contexto del proyecto" (Ruiz, comunicación personal, 2018). Se trata de recuerdos que han pervivido a través de los años y se actualizan en los sucesos violentos y deliberados que han convertido al río Cauca en un escenario paradójico de esperanza y desolación. Gabriel Posada lo expresa de este modo:

Llevo en mí el secreto de un niño, una imagen, una persona muerta que flota por el río Cauca. Lo vi un día, a finales de la década de 1960, como a las siete de la mañana, desdeel puerto de La Virginia, Risaralda, al acompañar a mi padre a pescar. Lo vi, lo viví, viví la muerte constantemente desde esa mañana en muchas de nuestras reiteradas idas a pescar, a través de ese primer muerto coronado de "sirenas", una verde planta que recoge el río y lleva en su cauce premoniciones de crecientes.

Un segundo muerto, hinchado y morado; un tercero, navío de aves negras; hirviendo de moscas, como cocuyos encendidos... inmensamente solitarios, profundamente abandonados en las aguas, sin Dios y sin Ley. Crecí hipnotizado con el negro aletear de gallinazos en desfile, al reflejar un narciso cadavérico sin voz y sin llanto, sacrificado al olvido. (Posada, comunicación personal, 2018)

A partir de una serie de recorridos, realizados entre agosto y octubre de 2008 , los dos artistas caminaron cerca de 70 kilómetros, en un trayecto que iniciaba en la vereda Beltrán, municipio de Marsella (Risaralda), para despuntar en la vereda Cauca, municipio de Cartago, Valle del Cauca. A lo largo de este peregrinaje, la pareja fue escuchando testimonios, historias y anécdotas relacionadas con los sucesos violentos ocurridos en los últimos años en esos territorios. De manera paralela fueron "rayando una cartografía constante de hallazgos simbólicos, relatos míticos y fantasmales, franqueados humildemente por sus habitantes en medio de meandros, olvidos y naufragios conspirados por la crueldad del hombre" (Ruiz, comunicación personal, 2018).

La conversación con los lugareños les dio el soporte afectivo, contextual y vinculante para detonar el sentido amplio de la obra. A las imágenes de la muerte que sitiaban los recuerdos de infancia de Gabriel Posada, se sumaba el gesto reiterado de las mujeres de la zona, abatidas en un luto sostenido de dolor y ausencia, a causa de la indiferencia del Estado y la imposibilidad de encarar la fuerza impetuosa de un río que parecía haber conjurado la vida de los suyos. Entre los relatos se colaban mitos y fantasmas que comprometían una relación particular con el contexto, al tiempo que acrecentaban el deseo de sanar la pérdida, exorcizar el dolor y resignificar el silencio en el que los había sumido el terror de la muerte. 
En un ejercicio procesual de largo aliento, los artistas se propusieron construir con las comunidades una serie de intervenciones efímeras, configuradas como acciones de duelo, en las que se involucraban el río como metáfora de vida y de muerte, en su fluir constante, turbio, furioso, evanescente.

En este proceso participaron de manera directa muchas de las mujeres que fueron presenciaron la masacre de Trujillo en el Valle del Cauca, la cual, según el Grupo de Memoria Histórica (2008), dejó 342 asesinatos comprobados, perpetrados por el Estado, el paramilitarismo y el narcotráfico, en el breve lapso de 1989 y 1994. Fueron ellas, sus voces y sus memorias, las que se comprometieron más a fondo con la ruta propuesta por los artistas para desarrollar el proyecto de intervención in situ y, por esta vía, intentar reconstruir sus historias, aportar testimonios de la experiencia vivida y apropiar recursos simbólicos y expresivos para ennoblecer la memoria de sus muertos, como un acto de resistencia frente al olvido que instiga la desaparición forzada.

Los gestos de duelo se concretaron en la elaboración de una serie de balsas, a partir de materiales encontrados en la propia ribera del río, en las que se instalaron las imágenes recreadas por los colectivos de la comunidad en conjunto con los artistas. Los materiales y los soportes también respondieron a un mismo principio de economía comunitaria en el que se creó a partir de lo existente: costales de yute, fibras plásticas, telas que ya cumplieron un ciclo de vida útil y otros soportes más encontrados en el entorno. La pintura, el collage y el montaje fueron las estrategias que permitieron condensar las experiencias disímiles de cada taller colectivo. Las imágenes fueron cuidadosamente ancladas a las balsas y dispuestas en el orden ritual, a modo de "una instalación fúnebre que insistió en la comparecencia de ese doble cuerpo que desde hace años representa la parte más vulnerable de una sociedad, la más violentamente embestida y la más abandonada por la justicia: las madres y sus hijos, los muertos y sus dolientes", como lo puntualizó en su momento la investigadora Ileana Diéguez (2013, p. 202).

El 2 de noviembre de 2008, el 30 de marzo de 2009 y el 17 de abril de 2010, diecisiete balsas de guadua de 9x6 metros, se deslizaron a lo largo del río Cauca, portando las imágenes de luto creadas en este proyecto colectivo. El recorrido fue acompañado por los habitantes de Trujillo, hasta el lugar donde el río era navegable. Luego las balsas fueron soltadas para que continuaran su recorrido hasta perderse en el horizonte, hasta volverse metáfora de lo inescrutable. Este ritual silencioso testificaba el desprendimiento de un deseo, la renuncia a una espera interminable, frente a un cauce cargado de secretos y sedimentos, que nostálgicamente arrastró las balsas, estrujándolas contra los meandros de la corriente, fusionándose, como en la vida diaria, en sus corrientes imprevistas.

Las Magdalenas que viajaron por las corrientes del Cauca convocaron un doble registro alegórico. Uno más matérico y representacional en los cuerpos pictóricos montados sobre vestigios. La fragilidad de las balsas y la decisión de abandonarlas a las corrientes del río producía una asociación con el destino de los cuerpos encontrados en las mismas aguas. Allí emergía un registro, más fantasmal si se quiere, en la comunitas silenciosa e invisible que convocaban las balsas navegando el río (Diéguez, 2013, p. 203).

Esta obra testificó, por otra parte, el duelo colectivo de la comunidad o, por lo menos, la posibilidad de este como acción afectiva y pública. Por eso, los registros fotográficos de este proyecto quedaron instalados en un espacio del municipio, como testimonio de un ejercicio de reconstrucción de memoria, cohesión social y participación comunitaria, que todavía tiene resonancia en el país, especialmente entre los habitantes de esta localidad del Valle del Cauca.

\section{7 alumbramientos por las huellas del olvido}

En 2013 el colectivo "Magdalenas por el Cauca" convocaron de nuevo a los familiares de las víctimas de la masacre de Trujillo (Valle del Cauca), a las comunidades del municipio de Marsella y una de sus veredas, Beltrán (Risaralda), para construir 327 pequeñas balsas y ponerlas a navegar en los últimos 200 metros de La Nona, una quebrada que nace en Marsella y desemboca en el río Cauca, en el Remanso de Beltrán. Se trataba de potenciar 


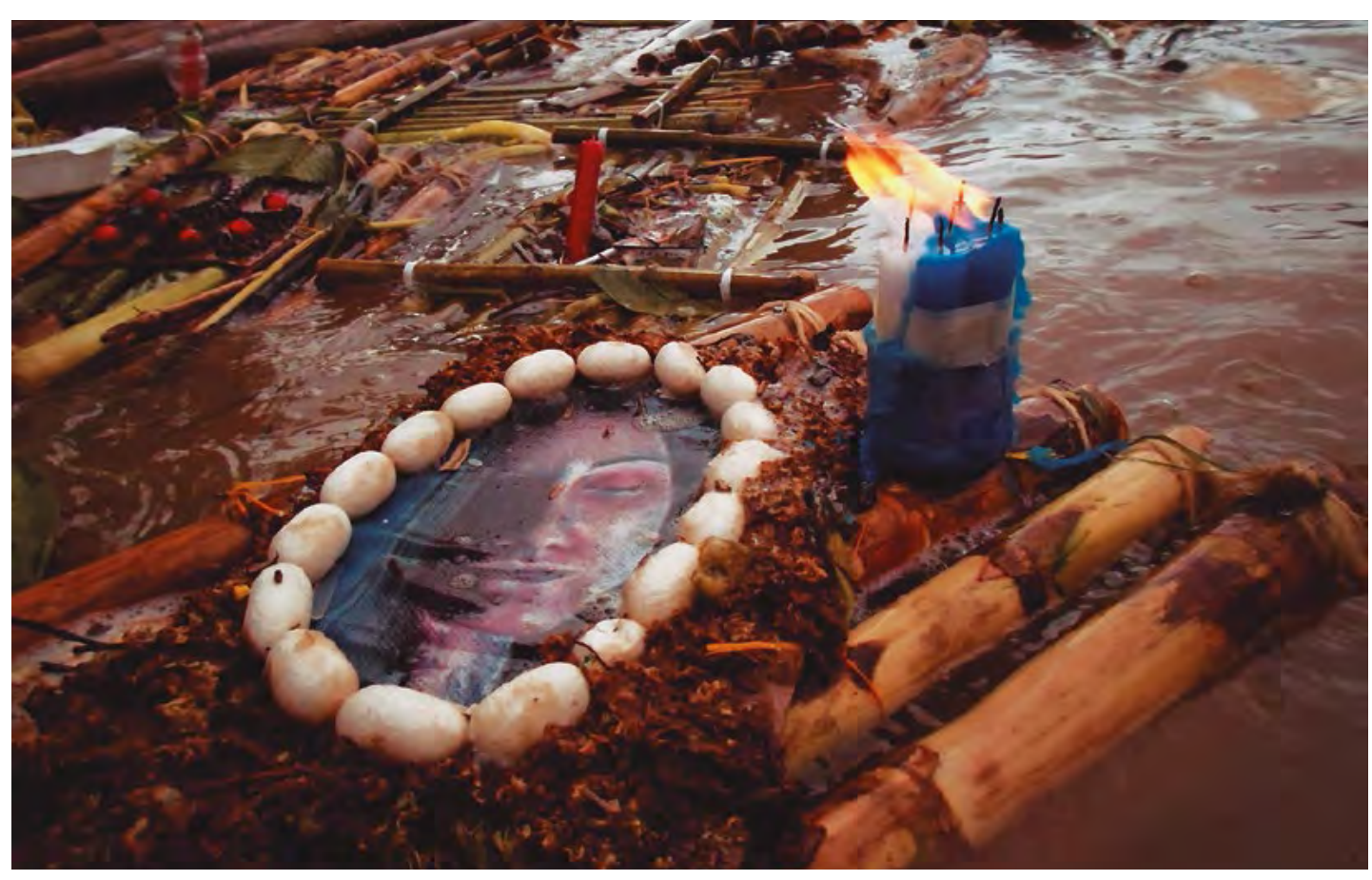

Ofrenda para balsa, 327 alumbramientos por las huellas del olvido pintura Juliana Bedoya, 2013. Fotografía: Gabriel Posad

Con el objetivo de denunciar la impunidad del Estado ante estos crímenes, la falta de interés por conocer la verdad de los hechos y visibilizar la incidencia de este fenómeno violento en los pobladores de la zona, los artistas convocarona a la comunidad para construir ofrendas conmemorativas, sobre pequeñas balsas, de tal manera que se activara la posibilidad de conferirle a los 327 cuerpos no identificados un nuevo trayecto o una nueva oportunidad de identificación en otro paraje, a partir del retorno simbólico al lugar donde fueron encontrados. Durante varios días los artistas trabajaron laboriosamente con colectivos de personas del lugar en la elaboración de las ofrendas, enfatizando en un gesto poético con el que buscaban llamar la atención sobre la problemática de la desaparición forzada en el país y reclamar, por este lindero, la pronta identificación de los cuerpos, "para que su recuerdo no se quedara en el olvido", según subrayaron los creadores de la obra. Se trataba también de una acción de señalamiento y resistencia, para cuestionar el poco interés del Estado por esclarecer la verdad de los hechos y comprometerse con la reparación simbólica y material de las víctimas.
4. Según una fuente del escritor Juan Miguel Álvarez, los habitantes de Beltrán atendían
una orden de la policía del municipio y de los gobiernos de turno, interesados en no afectar la gestión administrativa del municipio y el departamento con el incremento de las tasas de homicidio reportadas. Por eso, los lugareños se habrían dado a la tarea de impulsar con palos los cuerpos que atracaban en el Remanso de Beltrán; de tal manera que la recuperación de los mismos fuera tarea de la localidad vecina. 
En coherencia con los planteamientos de Nelly Richard (2007), podríamos señalar que en estas acciones del colectivo "Magdalenas por el Cauca" se evidencia cómo "practicar la memoria” implica, además de la capacidad para convocar y provocar a las comunidades, disponer de los instrumentos conceptuales e interpretativos necesarios para penetrar la densidad simbólica de los relatos que compromenten algunos trayectos de la historia:

'Expresar sus tormentos' supone recurrir a figuras de lenguaje (símbolos, metáforas, alegorías) suficientemente conmovidos y conmovibles para que entren en relación solidaria con el pasado victimizado El consenso oficial nombra hoy la memoria con palabras libres de toda convulsión de sentido, para que ninguna desatadura emocional del recuerdo altere el formulismo minuciosamente calculado del intercam-

bio político-mediático. (Richard, 2007, p. 136)

Tres dispositivos emergen de los procesos desarrollados por este colectivo en acciones como las que representan el propio proyecto de Magdalenas por el Cauca y, puntualmente, 327 alumbramientos por las huellas del olvido: primero, la construcción de una arqueología de la memoria, configurada por una serie de acciones colectivas que indagan por los lugares del recuerdo, para visibilizarlos en una suma de inscripciones, cuerpos y formas sensibles que alteran los espacios y los tiempos en los que discurre la experiencia de los acontecimientos violentos. Segundo, la configuración de una iconografía de lo ritual, como acción colectiva y espacio de reelaboración de los síntomas y las huellas de la perturbación causada por las acciones sacrificiales del cuerpo y del tejido cohesionador de las comunidades. Finalmente, la explicitación y activación de un régimen ampliado de lo sensible como mediación, que compromete colectivos de víctimas y personas de la sociedad civil con acciones, gestos y comportamientos en los que se va configurando una nueva relación con lo sensible, otras formas de mirar, de escuchar, de decir y de visibilizar la relación con nuestro presente.

Aunque cada obra creada por el colectivo parte del interés particular por movilizar sentidos y ampliar las posibilidades que motiva el trabajo con lo sensible, es importante reconocer el valor que comportan estas acciones para el campo de las humanidades y las ciencias sociales, en la medida en que apuntan a configurar un espacio de convergencia, más allá del lugar que ocupan Yorlady Ruiz y Gabriel Posada en este campo de actuaciones estéticas, culturales y políticas. Ese más allá cobija su relación con un momento histórico, con un sistema de pensamiento, con una noción de arte, de espacio y de tiempo, que son dominantes en la época y que marcan las tensiones más fuertes de su trabajo, en la medida que ponen de presente el lugar de la memoria como posibilidad para crear y reflexionar los acontecimientos que comprometen nuestra humanidad usurpada, saqueada, reducida.

A propósito de estas acciones, Catalina Cortés (2011) considera que las mismas se complementan, dado que:

permiten evocar y re-imaginar lo social y cultural a través de prácticas estéticas queproponen otras relaciones con el pasado, el presente y el devenir al crear otros regímenesde lo sensible y lo inteligible, visibilizando la complejidad de las inscripciones de las memorias en cuerpos, lugares, objetos, sustancias y cuya sustancia es la cotidianidad. (p. 12)

Con todo, la carga simbólica, política y expresiva que comportan estos proyectos, empuja las fronteras temporales y los límites creativos que encierran las representaciones, para colocarnos frente a una amalgama de fisuras sensibles. Es un hecho que lo creativo y su representación detonan las polifonías y amplían los sentidos de enunciación en el seno de una sociedad sitiada por las ruinas del despojo, la devastación y la indiferencia.

\section{Prácticas de cohesión y resistencia: crear para sobrevivir}

Además del trabajo que despliegan algunos artistas en territorios afectados por la violencia, resulta significativo el impulso que alcanzan algunos proyectos de carácter social y comunitario, en los cuales las propias comunidades afectadas por los fenómenos violentos se organizan en torno a prácticas estéticas o ejercicios expresivos, que se nutren del trabajo colaborativo, la ritualidad del encuentro y el sentido que entraña la labor creativa, en términos afectivos, simbólicos y políticos. La mayoría de las veces la mediación de los procesos es agenciada por el liderazgo social 
de algunos grupos o por un equipo interdisciplinario de profesionales, capacitado para intervenir psico-socialmente a las comunidades. Desde esta praxis, se insertan provocaciones para resignificar las experiencias traumáticas de unas colectividades escindidas, fracturadas por la acción de los violentos y debilitadas frente al pírrico accionar de las instituciones legitimadas por los entes oficiales de gobernabilidad.

Al cuestionarnos, como lo advierte la ensayista Adriana Valdés (2008), si existe una especificidad contemporánea de las imágenes, derivadas de la experiencia de vivir en una era mediática donde "se mira sin ver" y donde el sufrimiento ajeno, en lugar de conmover y movilizar la acción social, se transforma en objeto de consumo masivo e incita al espectador-consumidor a colocarse a salvo de los acontecimientos y de las representaciones incómodas, debemos señalar que, en efecto, sí existe tal condición y a ella responden, justamente, los viejos y los nuevos medios de comunicación, habituados a atender con eficacia a las demandas de unos públicos voraces, formados en el régimen escópico de la medialidad y la instantaneidad. A este regimen especulativo y promiscuo de la imagen se opone, por fortuna, una nueva densidad de lo expresivo, mediada por la intervención del gesto creativo, en la que es posible detener la mirada, escrutar el sentido, interrogar los acontecimientos y, si se quiere, responder con un contra-relato que instale una nueva duración de la mirada de quien no es ajeno a la revisión de la historia.

\section{Entretejer el afecto}

La incidencia de los diferentes grupos armados en algunos de las zonas más vulnerables del país ha forzado el desplazamiento de la población civil y su dispersión a lo largo y ancho del territorio. La representación de este fenómeno ha dado lugar a la creación de una serie de cartografías y construcciones simbólicas, en las que el territorio ya no está dividido por las convenciones de la georreferenciación tradicional, sino más bien por la concomitancia de fenómenos violentos en los que la población civil resulta menguada, sometida o acallada. De tal suerte que, como lo advierte el colectivo de la Corporación Ecomujer (2006), fenómenos como el desplazamiento forzado, el confinamiento, los bloqueos, entre otros, se han convertido en parte de nuestra cotidianidad, impidiendo el normal desarrollo cultural de los pueblos, e impulsando a hombres, mujeres y niños a abandonar sus contextos de arraigo en busca de refugio y seguridad, en espacios casi siempre ajenos a su cultura raizal.

Adicionalmente, se instala una "táctica de terror", practicada, sobre todo, por las bandas paramilitares que, como precisan los investigadores Olivier Pissoat y Vincent Gouéset (2002, p. 30), responde a una estrategia de control y de reapropiación del espacio, usada para forzar el abandono de los ocupantes de sus parcelas y acelerar la formación de nuevos flujos poblacionales, en contextos donde difícilmente pueden recuperar los vínculos sociales y culturales que los identificaban y cohesionaban. Además de la complejidad inherente al trasfondo social que generan estas rupturas, este tipo de experiencias detonan el surgimiento de movimientos y liderazgos colectivos que, además de luchar por una reparación efectiva,

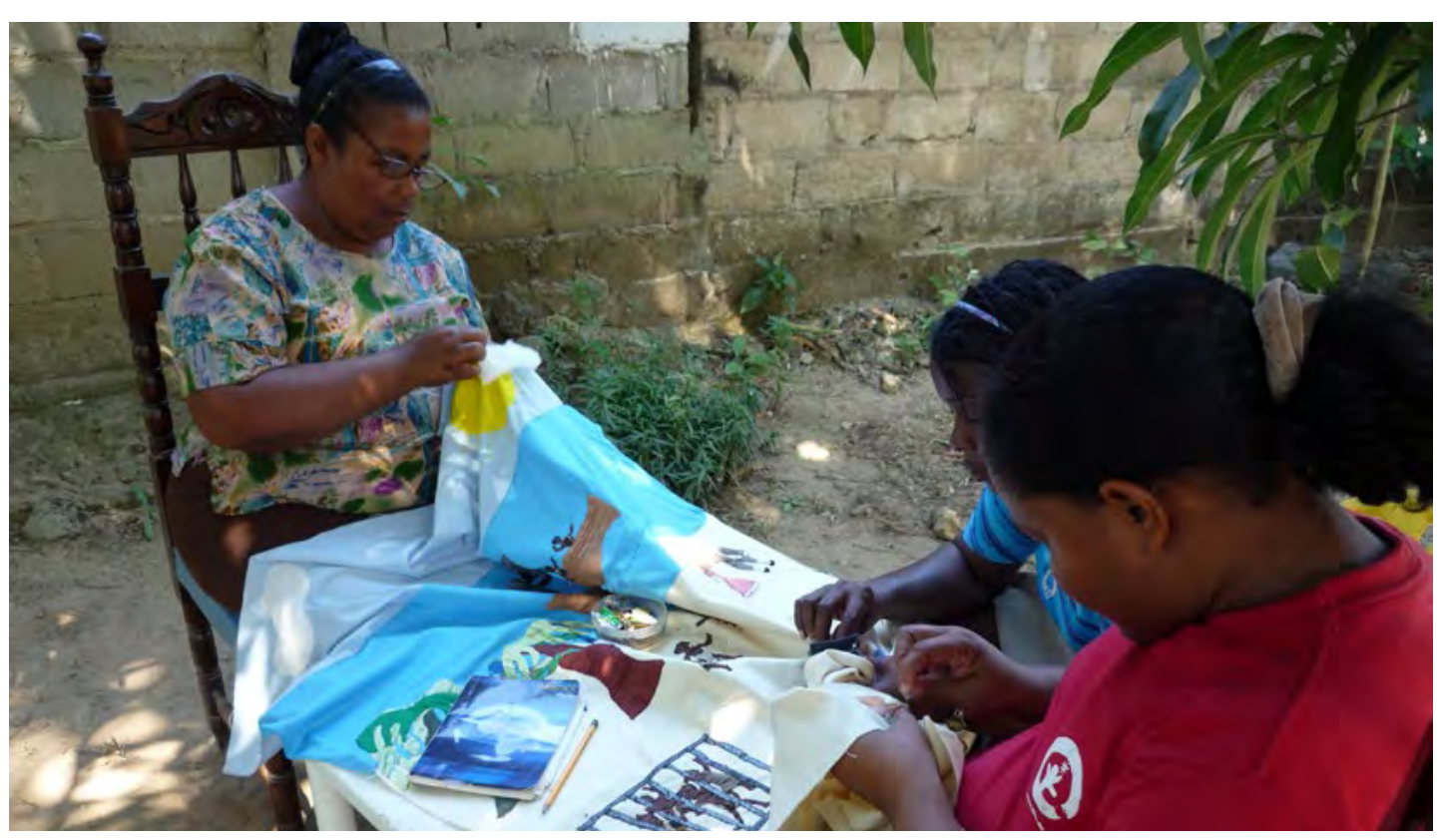

Tejedoras de Mampuján. Fundación Puntos de Encuentro 
buscan reivindicaciones y agenciamientos afectivos, que sirvan como recurso para repensar el sentido y el valor que entraña sentirse y reconocerse como parte de una comunidad. Es ahí, en el seno de estas emergencias, donde están teniendo lugar una serie de experiencias y prácticas expresivas, en las que se gestionan formas de volver a coexistir, que tienen como tamiz constitutivo el universo emocional y afectivo de las personas.

De acuerdo con David Le Breton (2013), las emociones constituyen el factor que más incide en la agencia y la efectividad de estas experiencias. Para este autor, las emociones configuran "un matiz afectivo que se extiende por todo el comportamiento, y que no cesa de cambiar en todo instante, cada vez que la relación con el mundo se transforma, que los interlocutores cambian o que el individuo modifica su análisis de la situación” (p. 69). Son, pues, estos estados afectivos, condiciones de relacionamiento claves para movilizar la acción e impulsar a los sujetos o a los colectivos, que hacen parte de los movimientos sociales, a avanzar tras un propósito o un fin. De manera correlativa, complementa James M. Jasper (2013), las emociones pueden ser medios, fines o una fusión de ambos, y pueden favorecer o dificultar los esfuerzos de movilización, las estrategias y el éxito de los movimientos (p. 47). No obstante, al lado de las emociones, es necesario considerar el papel fundamental que tiene la cooperación y la movilización colectiva como lugar para pensar la acción social y la mediación de lo afectivo, como motor de inspiración para el logro de un propósito común.

Uno de los casos emblemáticos para reflexionar estas experiencias surge en el corregimiento de Mampuján, en María La Baja, Bolívar. El 10 de marzo de 2000, alrededor de 245 familias de esta población fueron obligadas a abandonar su territorio a raíz de la incursión de un escuadrón paramilitar en esa zona, convertida, para el momento, en escenario de pugna entre grupos de la guerrilla de las FARC y grupos paramilitares por el control militar, político e ideológico del territorio. En su afán por dirimir el conflicto, la fuerza pública, que centró sus esfuerzos en la lucha contrainsurgente, terminó estigmatizando a la población civil al confundir el accionar de los movimientos sociales con el del grupo guerrillero, según lo documenta el Centro Nacional de Memoria Histórica (2018).
Diferentes agentes, algunos vinculados a organismos internacionales, participaron de las tareas de reubicación de la población y apostaron, tanto por la reconstrucción material del pueblo como por la reconfiguración del simbólica del tejido social fracturado. El Estado colombiano se marginó de la responsabilidad de asumir plenamente el proceso, tal como ha sucedido con otros contextos del territorio nacional.

Como una estrategia para mitigar el impacto del destierro un grupo de mujeres, impulsadas por Juana Alicia Ruiz, líder de la comunidad, empiezan a proyectar una iniciativa de creación de memoria a partir del tejido. De acuerdo con Juana Alicia Ruiz, Ruth María Romero y Anadelfy Ladeus (2019), la práctica del quilting surgió entre las mujeres de la comunidad en 2003, a partir de una serie de talleres orientados por la psicóloga estadounidense Teresa Geizer, quien se vinculó al proceso de reconstrucción de la comunidad de Mampuján, a partir de la enseñanza del quilt, en su forma tradicional. No obstante, los colectivos transformaron de manera radical la experiencia compositiva del tejido, operando un ejercicio de apropiación en el que, además de resignificar el lugar de origen de la práctica, introdujeron modulaciones a los repertorios. De esta forma, precisan Ruiz, Romero y Ladeus (2019), “las mujeres de Mampuján tejerían no figuras geométricas, sino figuras humanas, figuras que hablaran por ellas del dolor, del sufrimiento vivido por el conflicto armado.” (p. 75) Desde entonces, las creaciones del colectivo dejaron al margen el diagrama tradicional de formas geométricas superpuestas del quilt tradicional, para dar lugar a una narrativa sensible, de vivencias, desarraigos, dolor, miedo, ausencia, destierro, esto es, el tejido de emociones y circunstancias que afrontaron a raíz del desplazamiento sufrido.

En el contexto, resulta significativo reconocer el valor transgresor de estas maniobras de confiscación, sobre todo cuando tienen lugar, como advierte Gerardo Mosquera (2009), “desde posiciones de dependencia”, ya que, "además de confiscar para uso propio, funcionan cuestionando los cánones y la autoridad de los paradigmas centrales” (p. 262). Por esta vía, las premisas que movilizan la transmisión de prácticas y saberes asentadas en una matriz colonizadora resultan desajustadas, dando pie a una reelaboración de sus sentidos y a una apertura no prescriptiva de sus significados. 
De esta iniciativa tan cotidiana y doméstica surge el colectivo "Mujeres Tejiendo Sueños y Sabores de la Paz", una estrategia creativa, a la vez que un proyecto productivo cuyos efectos sociales, estéticos y políticos han resultado cruciales para los procesos de reorganización de la comunidad de Mampuján y la visibilización de su problemática en el contexto nacional e internacional.

La construcción de los espacios de encuentro y la realización de los tejidos responde a una metodología concertada y a una forma de organización que compromete: el testimonio o las historias relatadas por las mujeres, el saber del tejido, la estructura del tejido y su secuencialidad compositiva, y un espacio de intercambio de sabores a partir de la "elaboración de un dulce con fruta típica, leche de la región o alguna fruta silvestre con caldero, palote y leña", que sirve para afianzar el carácter afectivo del encuentro. Como bien lo narran Juana Alicia Ruiz (líder del grupo), Ruth María Romero y Anadelfy Ladeus (2019): "el tema de comer un dulce en medio de los talleres se convirtió en una necesidad que fortalecía el estado de ánimo y calmaba el hambre. El objetivo es condicionar la mente de la persona para llegar a un momento de paz y tranquilidad a pesar de estar

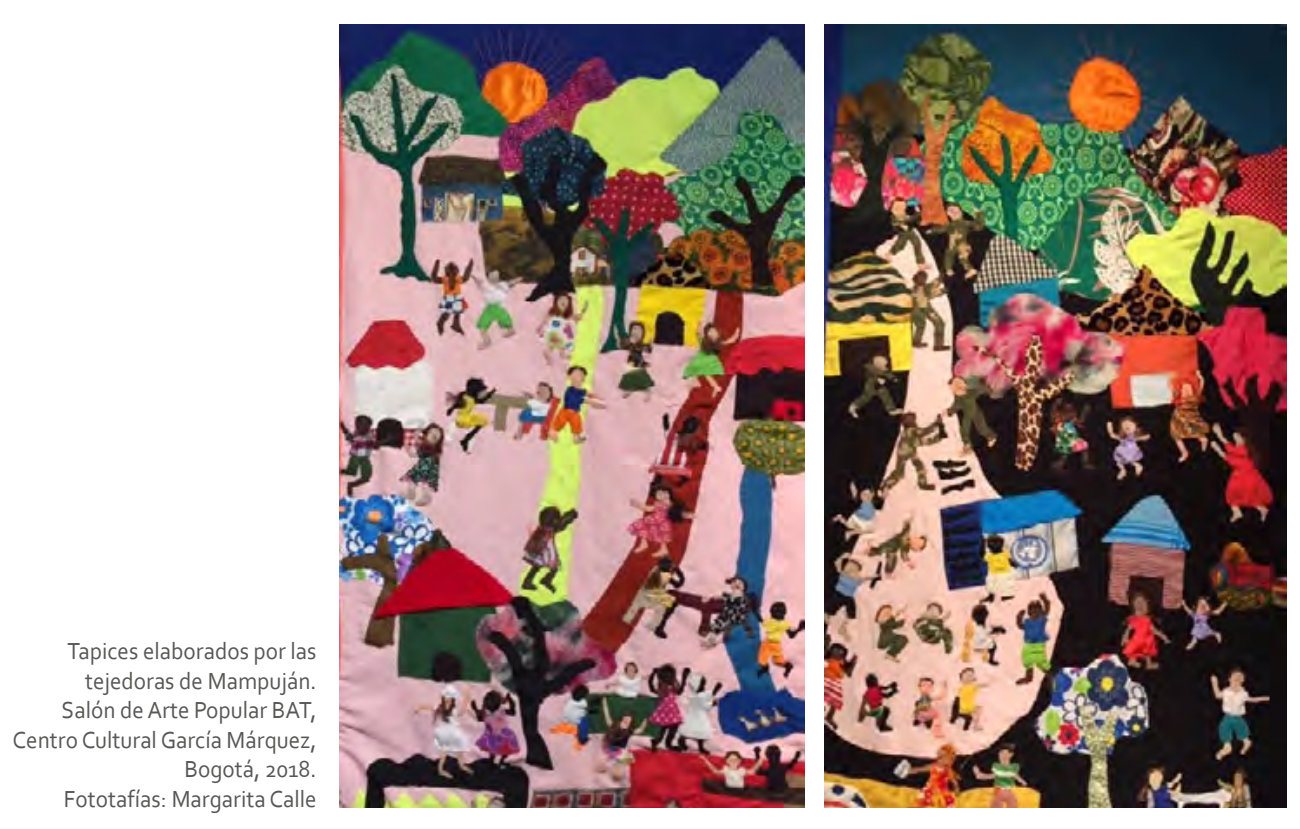

recordando lo sucedido.” (p. 94) Las sesiones de tejido responden a un carácter procesual y armónico; una ruta metodológica consensuada que le confiere un carácter eminentemente ritual al encuentro y al ejercicio creativo derivado de la actividad del colectivo. En términos metodológicos, el proceso configura una serie de secuencias que ejemplifican claramente el sentido de las acciones (Ruiz, Romero, Ladefus, 2019, pp. 94-96):

Secuencia 1: Preámbulo: en esta parte las participantes se organizan en un círculo, se presentan, hay una explicación de los objetivos de la metodología, se elabora un pacto de convivencia, se fijan algunas reglas para el desarrollo del trabajo y se puntualizan aspectos relacionados con la herramienta del tejido.

Secuencia 2: Testimonio: para la elaboración de los dibujos que representan el contexto de la vivencia, cada persona realiza un relato de los hechos vividos y un artista realiza notas o bocetos de manera gráfica, en una cartulina grande. De cada relato plasman los elementos del contexto de la experiencia narrada por la participante. Se cuida que ninguna historia o contexto se repita, para evitar incluir dos veces la misma historia en el dibujo. Una vez plasmados los contextos de los participantes, el artista responsable de hacer la relatoría socializa el boceto de la obra y realiza las modificaciones que las participantes sugieran; se intenta mantener cierta fidelidad en la representación del relato.

Secuencia 3: Ejercicio de relajación colectiva guiado por el terapeuta, el cual busca activar el cuerpo para participar de la construcción del tejido. Este ejercicio se realiza en parejas y se desarrolla a partir de masajes con aceite relajante que cubren desde las yemas de los dedos de la mano, (dedo por dedo "porque cada dedo expresa un sentimiento"), pasando por los codos, hasta llegar a los hombros de la compañera. Cuando las parejas construyen un espacio de mayor confianza se masajea también la espalda, las caderas, los pies, piernas, rodillas, muslos. La acción se replica invirtiendo los roles y se finaliza con una danza o un ejercicio físico de estiramiento.

Secuencia 4: Presentación de los materiales y explicación de las técnicas de cosido en tela sobre tela (quilt): se muestra un video del paso a paso. Cada participante decide qué parte del dibujo colectivo elaborará y, de acuerdo con esto, elige las telas para el tejido. Normalmente se trabaja 
sobre un fondo de mínimo 1.5 x $1.5 \mathrm{mt}$. De la misma manera que en el caso del dibujo, la tela se empieza a elaborar de atrás hacia adelante, dejando para elaborar en el último segmento las personas y los animales. De las personas se crean primero las siluetas y luego se visten, preferiblemente con tela que corresponda a la ropa usada por la misma persona o al menos con los colores o pintas más parecidos, sin alejarse de la moda o estilos característicos de este.

Secuencia 5: Pausas activas: es necesario realizar, de manera periódica, ejercicios de relajación que ayuden a paliar el estrés o tensión generada por el ejercicio de recordar lo sucedido, tales como: ejercicios de estiramiento, de movimiento y de integración que incluyan abrazos y risas al son de una música relajante o música de la región que transmita tranquilidad a los participantes. De manera paralela se va preparando el dulce elegido para la sesión del taller. Compartir el dulce elaborado hace parte de un ritual de empatía y fortalecimiento del espacio de encuentro colectivo.

Secuencia 6: Los rostros: una vez plasmados todos los elementos, se procede a crear los rostros con sus respectivas expresiones (de sorpresa, alegría, miedo, impotencia), y se bordan con hilos. Igualmente se colocan los cabellos cosidos según la etnia y el sexo; para esto utilizan cabello natural, sintético, lanas o telas.

Secuencia 7: Conmemorar: al finalizar el tejido se muestra la obra completa, se elige un nombre conmemorativo y se elabora de manera colectiva en el tapiz. Cada participante expone su relato en la construcción final.

Los espacios elegidos para las sesiones de tejido son variados y responden a circunstancias del contexto, a la motivación para el ejercicio y, sobre todo, a "la comprensión del proceder metodológico que le ha dado cuerpo a los encuentros de tejer, conversar, cocinar, probar, comunicar y sanar" (Ruiz, Romero, Ladefus, 2019, p. 95), pues se trata de un reto asumido por las mujeres de Mampuján como gestoras de paz, al pasar de ser vistas y asumidas como víctimas a mujeres resilientes, microempresarias, empoderadas de la construcción de paz de su territorio y de su comunidad. Por eso, cada acción parte de un diálogo y una concertación en la que se exige:

1. La voluntad firme y decidida de los participantes en un pacto sincero de confidencialidad.
2. Confianza en el colectivo para que la terapia pueda ser efectiva: cada uno debe estar seguro de que puede relajarse y despojarse de todo peso sin temor.

3. Cuando se van a realizar masajes relajantes, participan solo mujeres.

4. Está bien llorar, no se debe cohibir a nadie hacerlo.

5. Se escoge un relator (artista) o alguien que dibuje bien, un moderador y un documentador.

6. Tener un aroma circulando, como lila, menta, lavanda, brisa marina, lirio o rosas. (Ruiz, Romero, Ladefus, 2019, pp. 95-96)

En el acto de conversar y tejer las mujeres de Mampuján encontraron una oportunidad para reelaborar su propia historia y visibilizar, desde este ejercicio laborioso y refinado, otro escenario de la barbarie. Así lo relata en su crónica la periodista Gloria Posada de El Espectador:

Las primeras puntadas fueron de dolor. Cada vez que entraba la aguja para unir las telas, algo se desgarraba en su corazón y el llanto salía sin parar. Entonces estas mujeres soltaban la aguja y se secaban las lágrimas para seguir llorando. La colcha de retazos apenas tenía forma: unas montañas de fondo, unos caminos, algunos árboles y el arroyo; ahora tenían que dibujar las personas. Cada figura representaba a un vecino, amigo o familiar. Por eso dolía tanto, porque lo que estaban plasmando en la tela era su propia historia. (Posada, 2015)

Tela sobre tela, los telares de Mampuján configuran una particular disposición pletórica de narraciones, en las que se encadenan relatos y se ensamblan materialidades, mientras se combinan y reconstruyen las tramas de unas vivencias comunes. A partir de aquí se adquieren otros sentidos en el accionar simbólico que fragua el tejido y en la vitalidad del encuentro afectivo en la colectividad.

Para John Gregory Benalcázar y Nelson Molina (2017), investigadores de la Universidad del Valle, "la acción de ordenar, la llamada 'construcción de la trama' propicia un ejercicio analítico que inicia con la construcción de sentido ante los acontecimientos - y a partir de lo que ocurrió-“(p. 65). Es justamente ese ensamblaje de signos el que activa y pone en práctica formas de enunciabilidad y visibilidad que, en la perspectiva de estos investigadores articulan, por lo menos, cuatro rasgos analíticos que re- 
sultan claves para dimensionar el efecto de estas acciones en el contexto donde tienen lugar: La línea del suceso en la que se inscribe la experiencia enunciativa de las mujeres tejedoras; el despliegue del campo relacional; la red de actores sociales comprometidos en la reconstrucción del acontecimiento y los mediadores e intermediadores de la dinámica relacional que vincula el espacio-tiempo de los sucesos.

La labor iniciada por las mujeres tejedoras de Mampuján ha tenido una amplia resonancia en otros territorios del país, como estrategia para cohesionar a las comunidades fragmentadas por la violencia y el desplazamiento. En 2015, las Tejedoras de Mampuján obtuvieron el Premio Nacional de Paz como reconocimiento a la decisión de superar el dolor causado por la guerra, a partir de acciones y prácticas afectivas que les permitieron volver a reencontrarse como comunidad, como mujeres, como ciudadanas. Justamente la exposición Mampuján entretejido. Un camino estético para la paz, organizada por el Grupo de Investigación Derechos Culturales: Derecho, Arte y Cultura de la Universidad Externado (2016), con el apoyo de la Fundación Puntos de Encuentro, liderada por el artista Juan Manuel Echavarría, sirvió de escenario para poner en contexto esta experiencia de mediación estética y expresiva. Los testimonios de las tejedoras, recogidos en el catálogo de esta curaduría, dan cuenta de la trascendencia conferida por ellas a esta iniciativa. Dice Gladys López:

...comenzamos con los telares y en la medida que íbamos recordando lo vivido, pues comenzamos a sanar nuestro corazón y esa terapia de coser nos sirvió a nosotros para sanarnos, y me acuerdo que la primera vez que los victimarios llegaron a mampuján yo me dije “ ¿será que yo soy capaz de mirarlos a los ojos?, ¿será que yo realmente los perdoné?”.

[...] Y en el momento que los pude mirar sentí en mi corazón que dios había hecho algo en mi vida, porque realmente [...] lo que yo sentía por ellos ni siquiera se lo merecían, [...] dios fue quien sanó mi corazón, fue quien sanó mi vida y fue quien me llevó a perdonar para que yo pudiera estar en paz. Entonces, esos tapices realmente han sido para nosotros de mucha bendición.

Desde la perspectiva de este proyecto de investigación, en estas acciones se despliega un particular "reparto de lo sensible", tal como lo temati- za Rancière (2011), una estética de la política, que consiste en definir "lo común de la comunidad, en introducir sujetos y objetos nuevos, en volver visible aquello que no lo era y hacer que sean entendidos como hablantes aquellos que no eran percibidos más que como animales ruidosos” (p. 35). Son las prácticas estéticas, en tanto maneras de ser y de hacer, las que posibilitan que en un espacio-tiempo situado opere ese nuevo reparto de lo sensible, permitiendo que una conformación material -en este caso el tapiz- actúe como ligazón, para juntar de nuevo en la empatía y la confianza, a la comunidad asaltada por los usurpadores de la tierra y de la vida.

\section{Experiencias y acciones comunes}

Otra experiencia potente para ejemplificar estas formas de reparto de lo sensible la encontramos en los procesos que desarrolla la Fundación colombo-francesa Enfances 2-32, con sede en Pereira. Desde su creación esta ONG se ha ocupado de trabajar en la reconstrucción de los vínculos sociales y afectivos de niños y familias víctimas de diferentes formas de exclusión y violencia ${ }^{5}$. En sus procesos asume las prácticas estéticas y artísticas, los lenguajes expresivos y sus materialidades como espacio articulador de un programa de intervención social y formación integral en el que se vale de estrategias creativas para que los participantes de los procesos reescriban sus historias y, por esta vía, puedan recuperar la voz raptada por el sin-sentido de la tragedia y la fuerza destructora de la violencia. Algunos de los proyectos desarrollados por esta organización, dan cuenta del carácter eminentemente mediador que han tenido este tipo prácticas en los procesos de intervención social que los ocupan y el efecto transformador para las comunidades involucradas en cada iniciativa.

5. A partir de las negociaciones y firma de los Acuerdos de Paz, esta Fundación también ha apoyado iniciativas de la Agencia para la Reincorporación y la Normalización de Colombia (ARN), propiciando procesos de reintegración a la vida social de personas desmovilizadas de diferentes grupos en conflicto (Farc y paramilitares). 


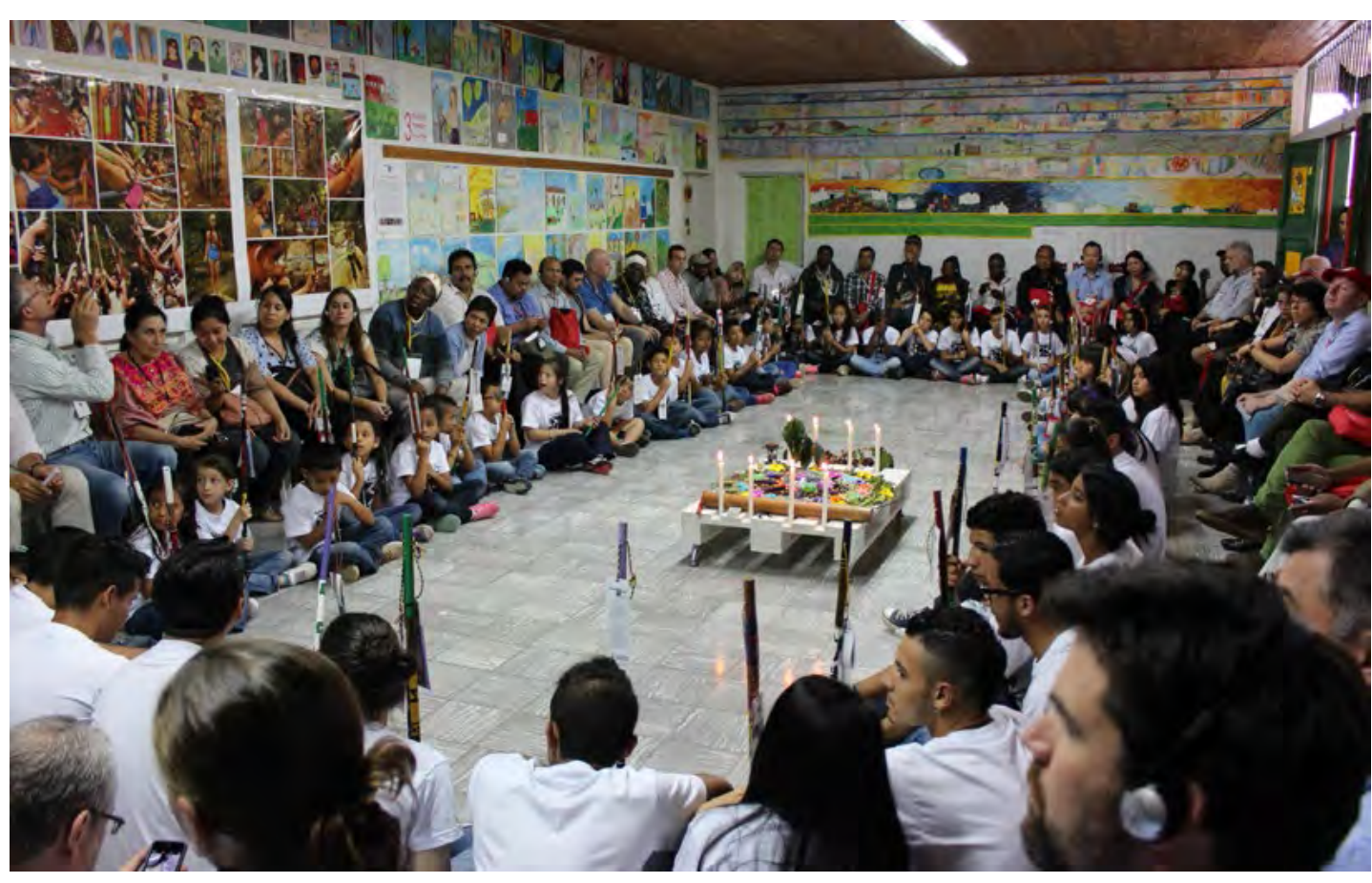

Delegados de la Comisión Técnica de Cooperación Sur-Sur (Reintegración, Reconciliación y Desarrollo desde los Territorios). Encuentro realizado en Pereira con la participación de representantes de Kenia, Irlanda, Mozambique, Indonesia, El Salva-
dor, Filipinas y Guatemala. Visita a la Fundación Enfances 2-32, 2015

Los niños y jóvenes que intervenían en la entrega de los bastones parecían conferir un mandato a los mayores relacionado con la reconciliación del país, de tal forma que a través de ellos los colombianos reconocieran en el fin del conflicto armado, la posibilidad de un nuevo comienzo.

En 2016, este mismo colectivo se propuso desarrollar el proyecto Del horror a la esperanza construido en torno a espacios compartidos de indagación y pensamiento, para reelaborar nociones como las de pasado, presente y futuro, por mediación de ejercicios de apropiación y resignificación de algunas obras de la historia del arte, centrales en la mirada estética occidental: El Guernica de Pablo Picasso (1937) y La balsa de la medusa de Théodore Géricault (1818-1819). Este espacio de creación se asumió como posibilidad reflexiva y crítica para narrar, a partir de unos motivos expresivos que no cesan de transmitir el gesto que los inspiró, una historia propia, en la que las violencias y la guerra son desterradas del territorio.

Recordemos que en el contexto de nuestra cultura, la obra de Picasso se ha constituido en un referente clave para representar el horror de la 
guerra y la magnitud que puede alcanzar el desborde de las violencias. Por su parte, la pintura de Géricault ganó en su momento una gran dimensión política por la manera como representó un acontecimiento del presente (el naufragio de la fragata Medusa, enviada a Senegal por el gobierno francés en 1816 y la incompetencia de este para atender la tragedia), e introdujo una crítica sobre el historicismo imperante en el arte de la época, para exaltar valores como la esperanza (o falta de ella), la vida, la incertidumbre y la angustia frente al destino.

En la apropiación de ambas obras los niños y jóvenes desplazaron los referentes originales para ubicar, como nuevo eje configurador, el complejo contexto que vivía el país en la tensión que representó el plebiscito
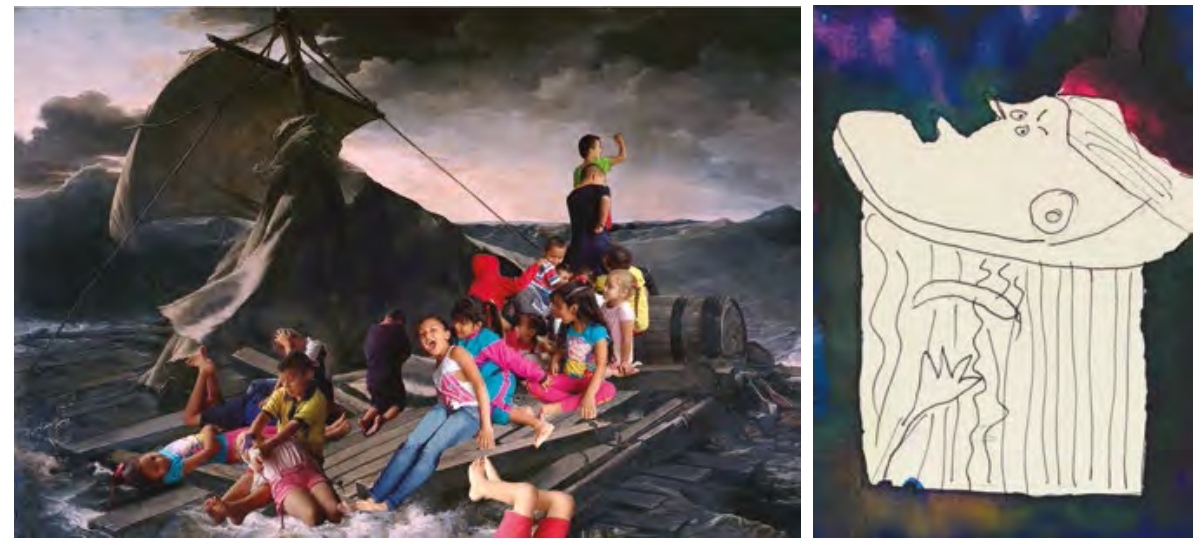

Recreaciones colectivas de la Balsa de la Medusa de Géricault y el Guernica de Picasso, realizadas por los niños de la undación Enfances 2-32, 2015
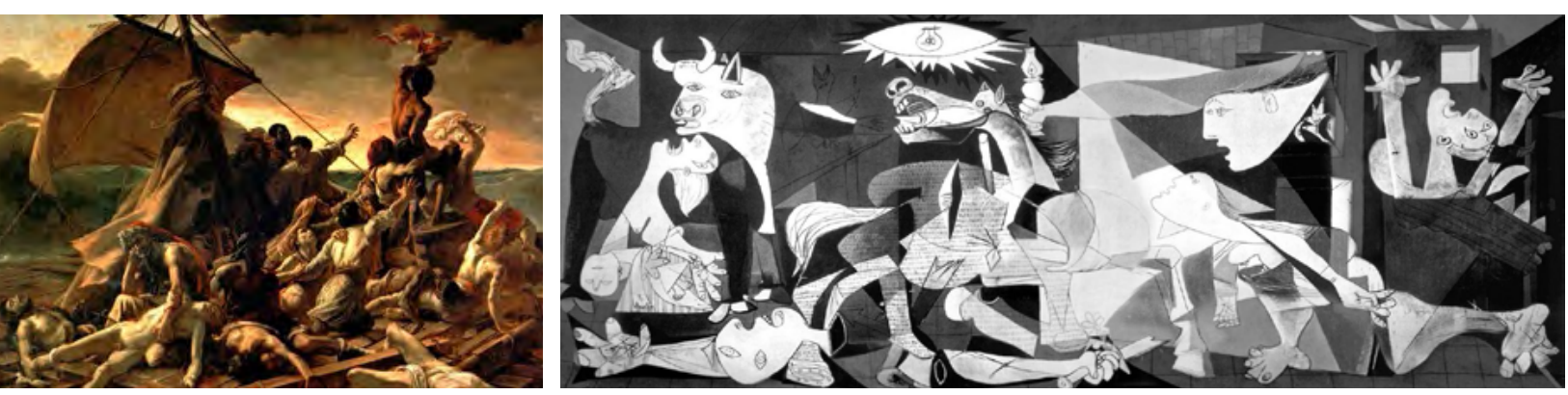

La balsa de la medusa. Théodore Géricault, 1818-1819 / El Guernica, Pablo Picasso, 1937 y la refrendación de los Acuerdos en 2016. Así, impulsados por la fuerza y la confianza que les transmitía la posibilidad de recrear la experiencia vivencial en el contexto de unos procesos estético-artísticos ampliados, los participantes se propusieron recrear otros espacios que actuaran temporalmente, activando procesos de mediación a nivel individual y colectivo.

A partir del dibujo, el collage y el collage-montaje los participantes recrearon el sentido de las obras originales de Picasso y Géricault, dando lugar a una extensa serie de nuevas imágenes y relatos, derivados del universo cotidiano y del imaginario de los protagonistas de este nuevo acontecimiento estético. De esta manera, dos realidades particulares, ligadas por los sentidos atribuidos a cada acontecimiento: el de la obra de arte y la de los imaginarios de la Paz, convergieron en un mismo escenario, para afianzar la posibilidad de recrear el presente, de reimaginarlo y traducirlo en nuevas narrativas, registros y soportes de transmisión, cercanos a la sensibilidad del presente. Fue esta una manera de interpretar la atemporalidad del arte y poner en juego "la implicación del arte en la constitución de la vida común”, como bien lo enfatiza Rancière (2013, p.37), por fuera de las narrativas historizadas y del espacio institucional del sistema del arte tradicional.

En coherencia con este interés por explorar las posibilidades de los dispositivos expresivos, la práctica del tejido también se ha convertido en un espacio recurrente en las acciones colectivas de la Fundación Enfances 2-32. Desde 2018 el proyecto Tejidos y multidiversos se convirtió en pretexto para vincular a niños y jóvenes de ambos sexos en un ejercicio de reconocimiento e inclusión, que propició la transformación de las narraciones personales de los participantes en producciones colectivas vistosas y provocadoras. En la tradición de nuestra cultura, el tejido se reconoce como una matriz de relatos en la que se condensan afectos y valores ligados con la identidad de los grupos sociales, los procesos de transmisión cultural y, de manera particular, la actuación de la mujer en el mundo doméstico. El proyecto desarrollado por este colectivo, además de interesarse por recuperar la idea del tejido como matriz cultural que anuda, sutura y recrea historias comunes, pone en tensión zonas de encuentro y conmoción, para expandir aquellos lugares de actuación restringidos a de- 

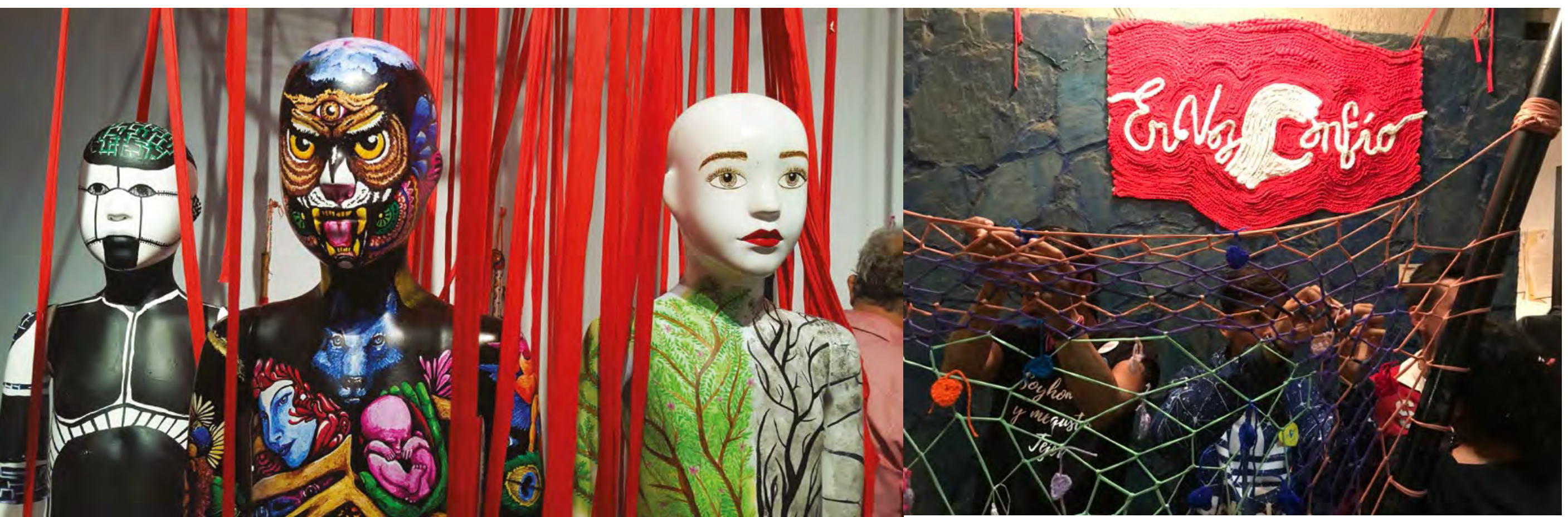

Proyecto Tejidos y multidiversos, realizado por los niños y jóvenes dela la

terminados sujetos o roles sociales. Por eso, además de tejer en el espacio privado, las personas involucradas al proyecto lo hicieron también en el espacio público, desplegando pequeñas acciones performativas ampliadas a la participación de aquellos espectadores que se dejaban provocar por el sentido del acontecimiento. De acuerdo con la directora de la Fundación, Amparo Villegas, en la labor social que empeña a esta organización los procesos expresivos de arte se han constituido en un factor diferencial para implementar iniciativas de atención integral enfocadas, sobre todo, a la infancia y la adolescencia:

A través de las prácticas del arte abrimos un campo de experimentación para que cada niño o niña potencie sus sueños y anhelos, y se confronte con su propia realidad, identificando las posibilidades para superar las frustraciones y los obstáculos encontrados en la sociedad, la escuela o el hogar. El arte dignifica la existencia de las personas, produce emociones y las impulsa a ser más proactivas. (Villegas, comunicación personal, junio de 2019)

Puestas en relación con las demás acciones desplegadas atrás, estas experiencias permiten comprender la relación afectiva que teje el trabajo manual y el potencial que alcanza el gesto expresivo cuando se revitaliza en el espacio común, es decir, en el ámbito de la comunidad. De este modo, se configuran formas materiales de visibilidad, capaces de dar cuenta de lo que somos o podemos llegar a ser en tanto grupo, en un momento dado.

Como dispositivo de transmisión, como mnemotecnia de la cultura, cada tejido anuda la síntesis material de una historia, una sensibilidad y una experiencia compartida. Estas conmociones re-sentidas en colectivo son la evidencia material de que hay escenarios donde las "maneras de ser" y de "hacer" se encuentran, para hablar de una acción recíproca que compromete acontecimientos, acciones y actores sociales posicionados.

A manera de cierre de este acercamiento, podemos decir que, en su conjunto, estas experiencias nos permiten hablar del despliegue de unas prácticas eminentemente estéticas, cuyo carácter se afianza en lo relacional, en la proxémica de los cuerpos y el intercambio colectivo de experiencias, como recursos para cohesionar los vínculos sociales de las comunidades. En la perspectiva de Rancière, estaríamos hablando de unos dispositivos expresivos "polémicos", que por su fuerza declarativa "tienden a desplazarse hacia una función de mediación social. Se convierten en 
testimonios o símbolos de una participación en una comunidad indistinta, y se representan en la perspectiva de una restauración del lazo social o del mundo común" (Rancière, 2010, p. 150).

Animadas por la incertidumbre y la disgregación de sus efectos, las imágenes, los acontecimientos y las experiencias que estimulan hoy las prácticas estéticas y artísticas, facilitan su despliegue por el mundo, buscando, recogiendo, desechando o apropiando los contenidos de una realidad fragmentada, excluida, para movilizar situaciones y afectos, a modo de renuncia a la anestesia con la que a veces experimentamos el presente.

$\mathrm{Al}$ asumir las creaciones artísticas como objetos históricos, transmisores de saber y de valoraciones culturales, que aparecen de manera intempestiva en el "flujo del devenir", reconocemos en ellas también "el material" que las restaura y rehabilita, al aparecer en circunstancias particulares, como desviaciones o desprendimientos de ese saber que ellas mismas se han empeñado en configurar. Es, justamente, esta condición imperfecta y abierta la que, según Didi Huberman (2010), le confiere a los procesos estéticos y artísticos la posibilidad de ubicarse "en el corazón del tiempo" (p. 49), en el curso histórico de las cosas; en el horizonte de lo que, aun haciéndose, sigue abierto.

\section{Referencias bibliográficas}

Acosta, M. del R. (2016). Resistencias al olvido. Memoria y arte en Colombia. Universidad de los Andes.

Álvarez, J. M. "El lugar donde llegan los muertos que lleva el río", en Revista Reconciliación Colombia, 4a. edición, http://reconciliacioncolombia.com/ web/historia/1536/el-lugar-a-donde-llegan-los-muertos-que-lleva-el-rio

Badiou, A. (2003). El ser y el acontecimiento. Manantial.

Belalcazar, J. G.; Molina, N. (2017). "Los tejidos de las mujeres de Mampuján: prácticas estético-artísticas de memoria situada en el marco del conflicto armado colombiano". En Revista Andamios, (Vol. 14 No. 34, México, may./ago.) https://andamios.uacm.edu.mx/index.php/andamios/article/view/563/910
Bourriaud, N. (2015). La exforma. Adriana Hidalgo editora.

Centro Nacional de Memoria Histórica. (2018). Narrativas de la guerra a través del paisaje, CNMH. http://www.centrodememoriahistorica.gov.co/micrositios/recorridos-por-paisajes-de- la-violencia/narrativas-guerra.pdf

Corporación EcoMujer. (2006) Cartografía de la esperanza. Editorial Gente Nueva. https://www.humanas.org.co/alfa/dat_particular/ar/Cartografia_de la_esperanza.pdf

Cortés, C. (2011). “Interacciones e intervenciones estético-políticas a través de prácticas artísticas: nuevas configuraciones estético espaciales”. En Gramáticas de la memoria. Arte, memoria y olvido, MEC, Universidad Tecnológica de Pereira. https://issuu.com/margcalle/docs/gramaticasdelrecuerdo

Diéguez, I. (2013). Cuerpos sin duelo. Iconografías y teatralidades del dolor. Ediciones Documenta Escénicas.

Jameson, F. (2015). "La estética de la singularidad", en New Left Review 92 (mayo - junio) Instituto de Altos Estudios de España.

https://newleftreview.es/issues/92/articles/fredric-jameson-la-estetica-de-la-singularidad.pdf

Jasper, J. M. (2012). "Las emociones y los movimientos sociales: veinte años de teoría e investigación”, en Revista Latinoamericana de Estudios sobre Cuerpos, Emociones y Sociedad, (vol. 4, núm. 10, diciembre-marzo, pp. 46-66) Universidad Nacional de Córdoba, Argentina. http://www.relaces.com.ar/index.php/relaces/article/view/240/237

Huberman, G. D. (2011). Ante el tiempo. Historia del arte y anacronismo de las imágene. Adriana Hidalgo Editora.

Foucault, M. (2003), La arqueología del saber. Siglo XXI.

Gadamer, H.G. (2002). La actualidad de lo bello. Paidós.

Grupo de Memoria Histórica. (2008). Trujillo una masacre que no cesa. Primer Informe de Memoria Histórica de la Comisión Nacional de Reparación y Reconciliación. Editorial Planeta. http://www.centrodememoriahistorica. gov.co/descargas/informes2008/informe trujillo.pdf

Malagón, M. (2010). Arte como presencia indéxica. Universidad de los Andes.

Mosquera, G. (2012). "Caminando con el diablo. Arte contemporáneo, cultura e internacionalización”, en Desde aquí. Contexto e internacionalización.

Posada, G. (2015). "Las tejedoras de Mampuján: la fuerza femenina del perdón”, en El Espectador, (Noviembre 19), https://www.elespectador.com/ cromos/hoy-historias-cronicas/las-tejedoras-de-mampujan-la-fuerza-femenina-del-perdon-16675 
Nancy, J. L. (2014). El arte hoy, Prometeo.

Neira, M. J. Historias: Mampuján, María La Baja, Bolívar. Universidad del Rosario, Bogotá, http://rutasdelconflicto.com/pueblos-olvido/node/41

Posada, G. (2018). Entrevista del equipo investigador con el artista, a propósito del proyecto Magdalenas por el Cauca.

Pissoat, O.; Gouëset, Vincent (2002), "La representación cartográfica de la violencia en las ciencias sociales colombianas", en Revista Análisis político (No. 45 2002-01-01), Universidad Nacional de Colombia, https://revistas. unal.edu.co/index.php/anpol/article/view/80120/70914

Rancière, J. (2005). Sobre políticas estéticas, Museu d'Art Contemporani de Barcelona.

Rancière, J. (2011). El reparto de lo sensible. Estética y política. LOM Ediciones.

Rancière, J. (2011). El malestar en la estética. Capital Intelectual.

Richard, N. (2007). Fracturas de la memoria: Arte y pensamiento crítico. Siglo XXI Editores.

Rubiano, E. (2018). “'La guerra que no hemos visto’ y la activación del habla”. En Estudios de Filosofía No. 58 (Julio-diciembre de 2018. Universidad de Antioquia, pp. 65-98) https://revistas.udea.edu.co/index.php/estudios_de_filosofia/article/view/329946

Ruiz, J. A.; Romero, R. M.; Teherán, A. L. (2019). Mujeres tejedoras de Mampuján. Un tejido con sabor a paz, Maestría en Conflicto y Construcción De Paz, Universidad de Cartagena.

Ruiz, Y. (2018). Entrevista del equipo investigador con el artista, a propósito del proyecto Magdalenas por el Cauca.

Tirsconia, A. "La guerra que no hemos visto. Un relato de memoria histórica”, http://www.laguerraquenohemosvisto.com/espanol/sobre-el-proyecto. html

Universidad Externado de Colombia. (2016). Mampuján entretejido. Un camino estético para la paz. Grupo de investigación derechos culturales: derecho, arte y cultura, con la colaboración de la Fundación Puntos de Encuentro.

Valdés, A.; Huberman, G.-D et al. (2008). Alfredo Jaar. La política de las imágenes. Metales Pesados.

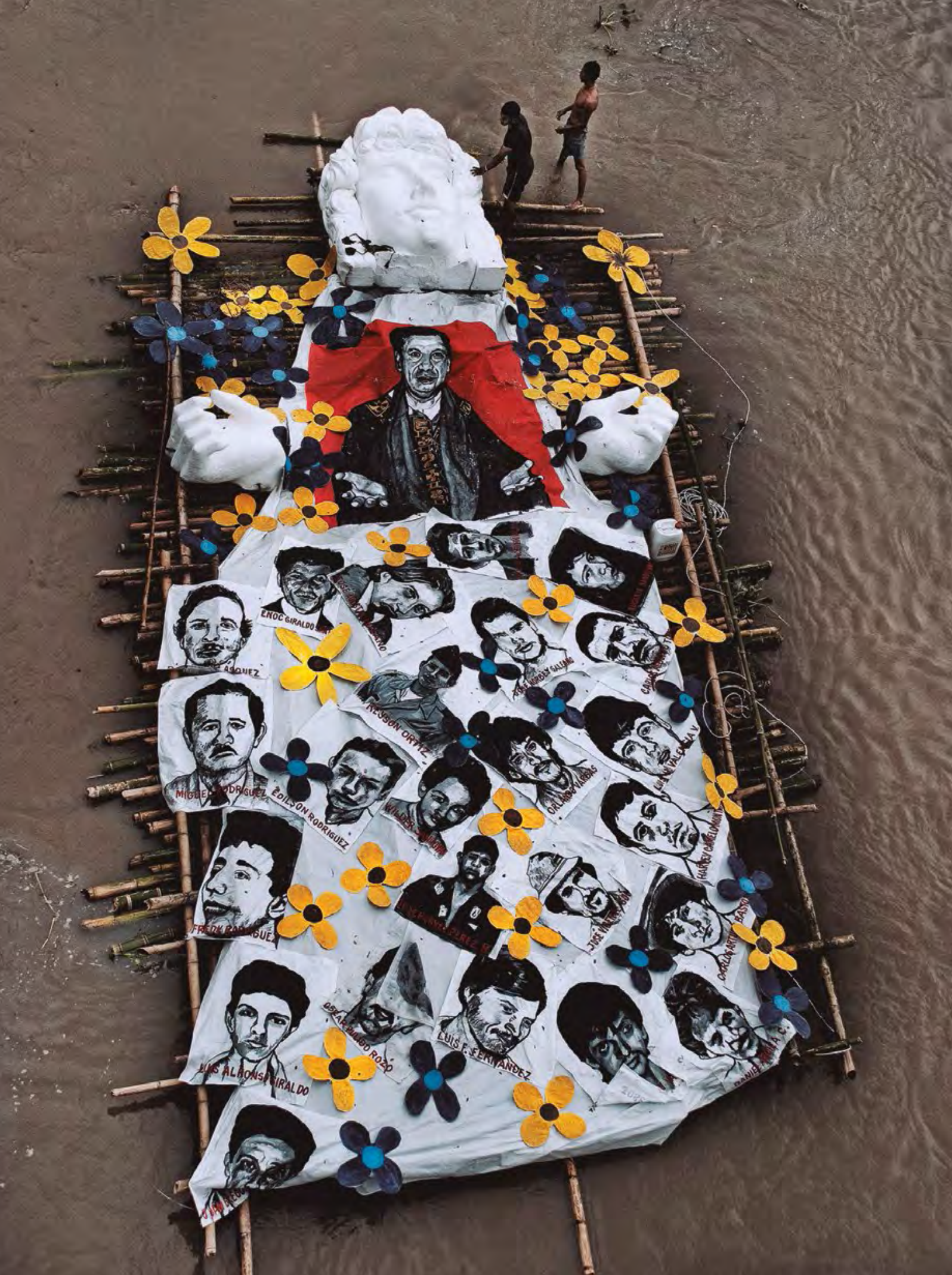




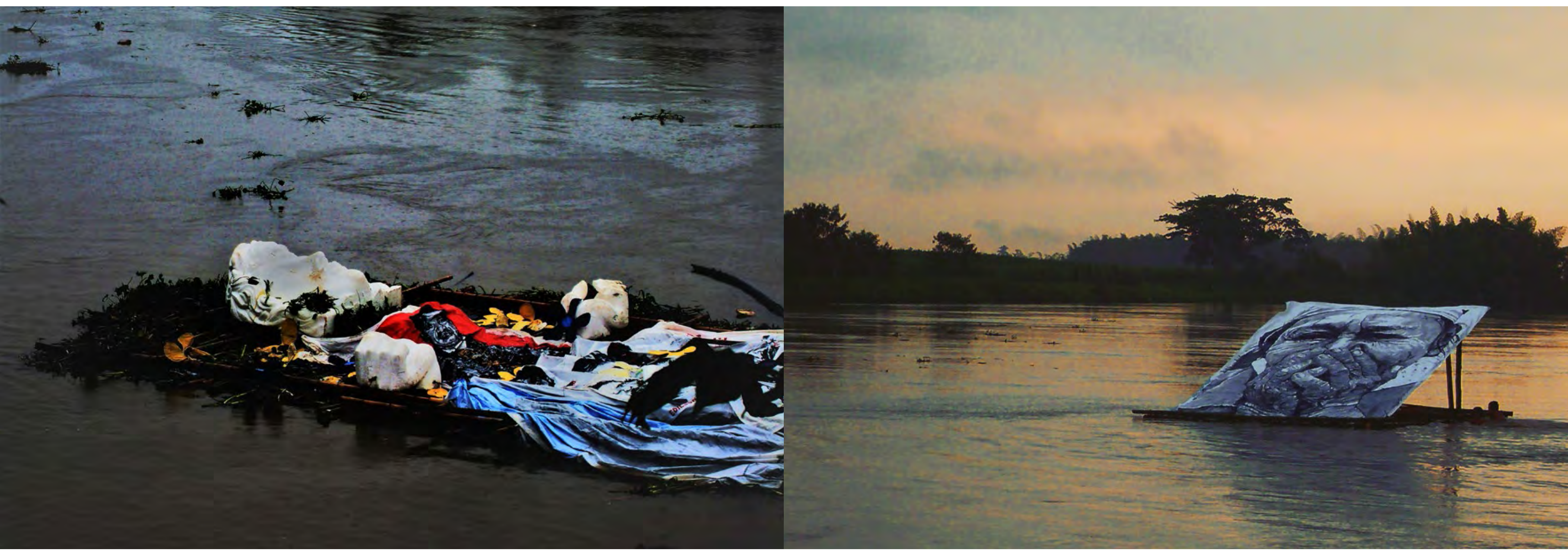




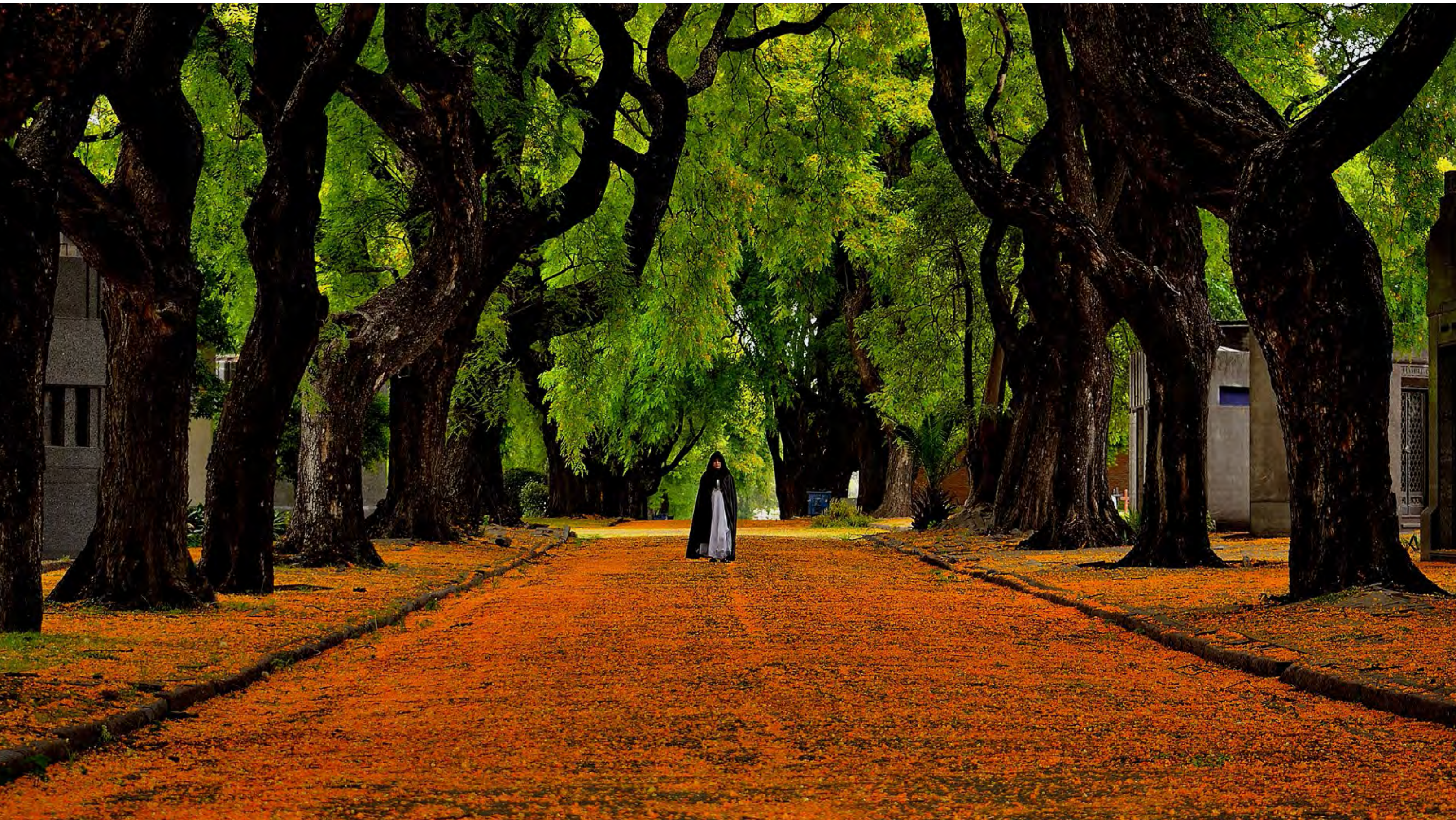

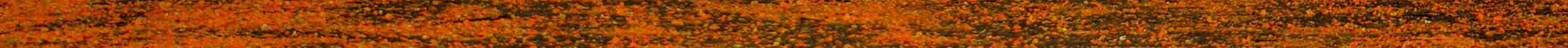

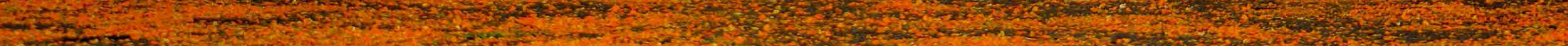

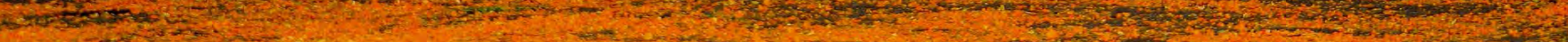

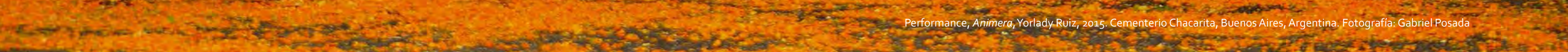

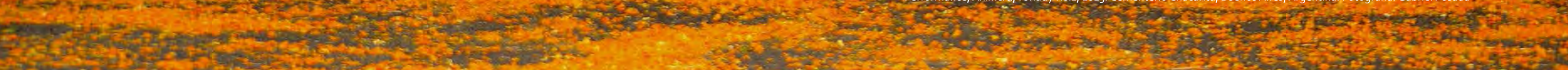



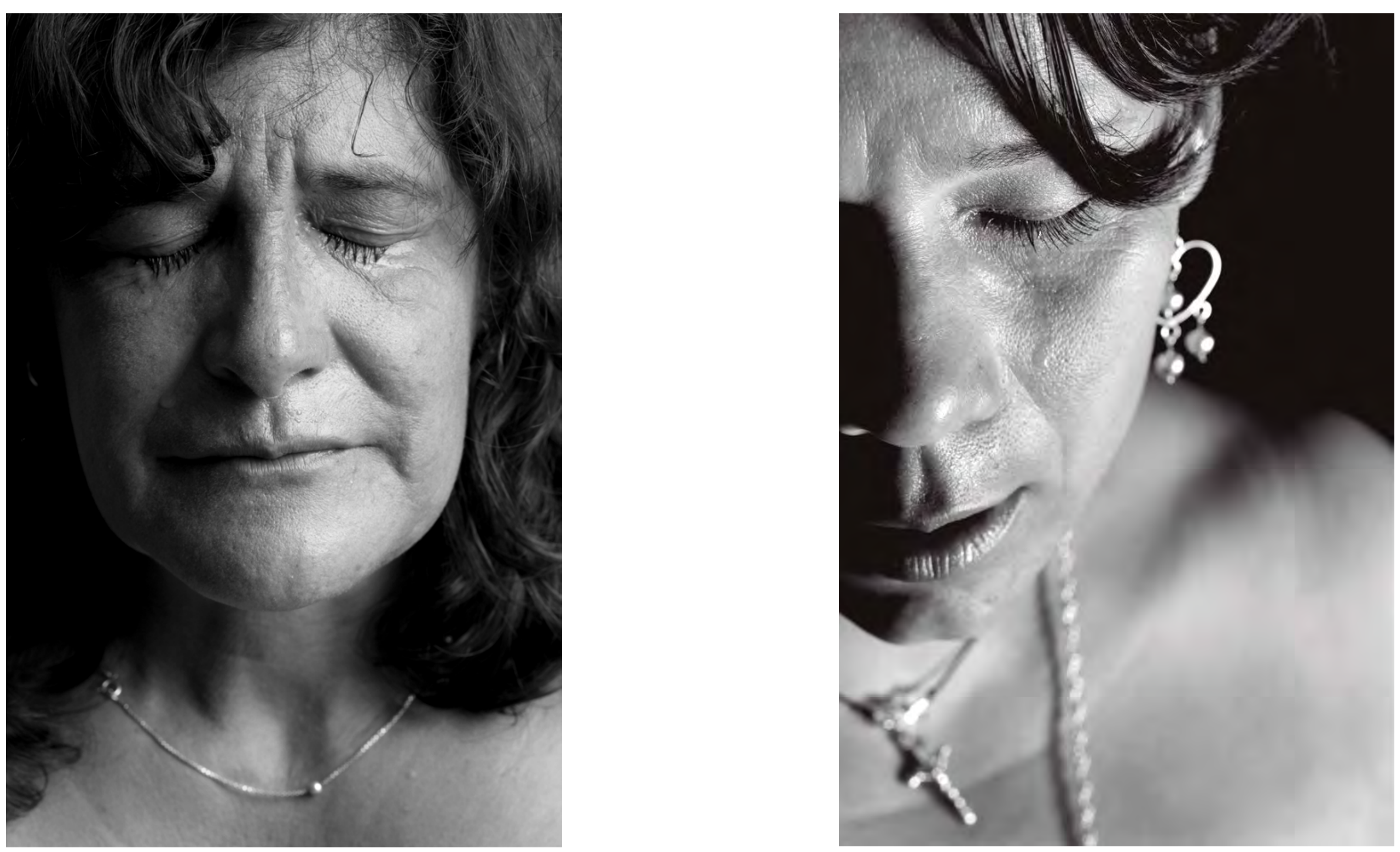


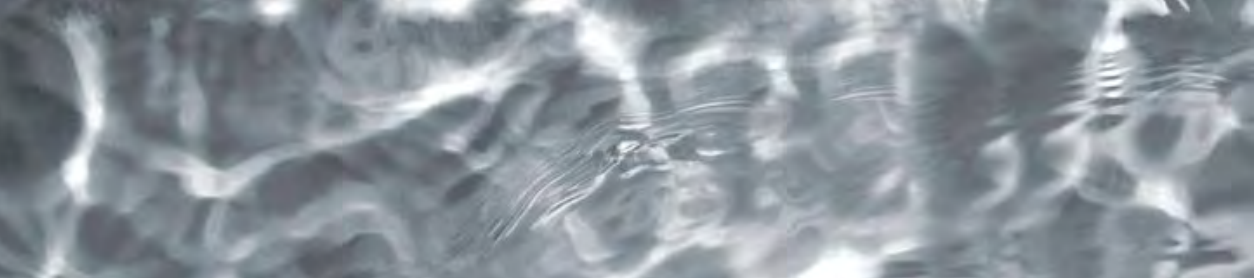

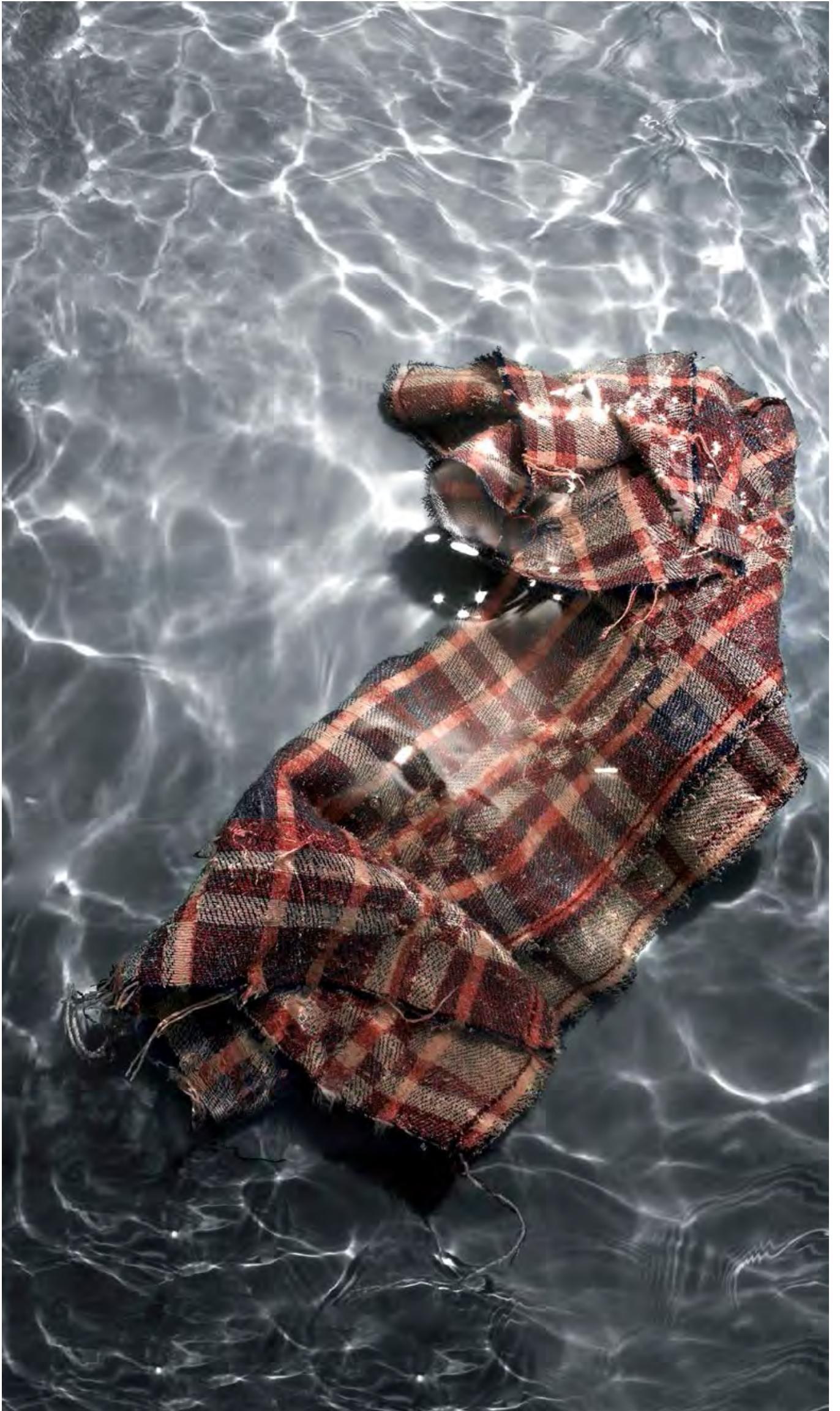




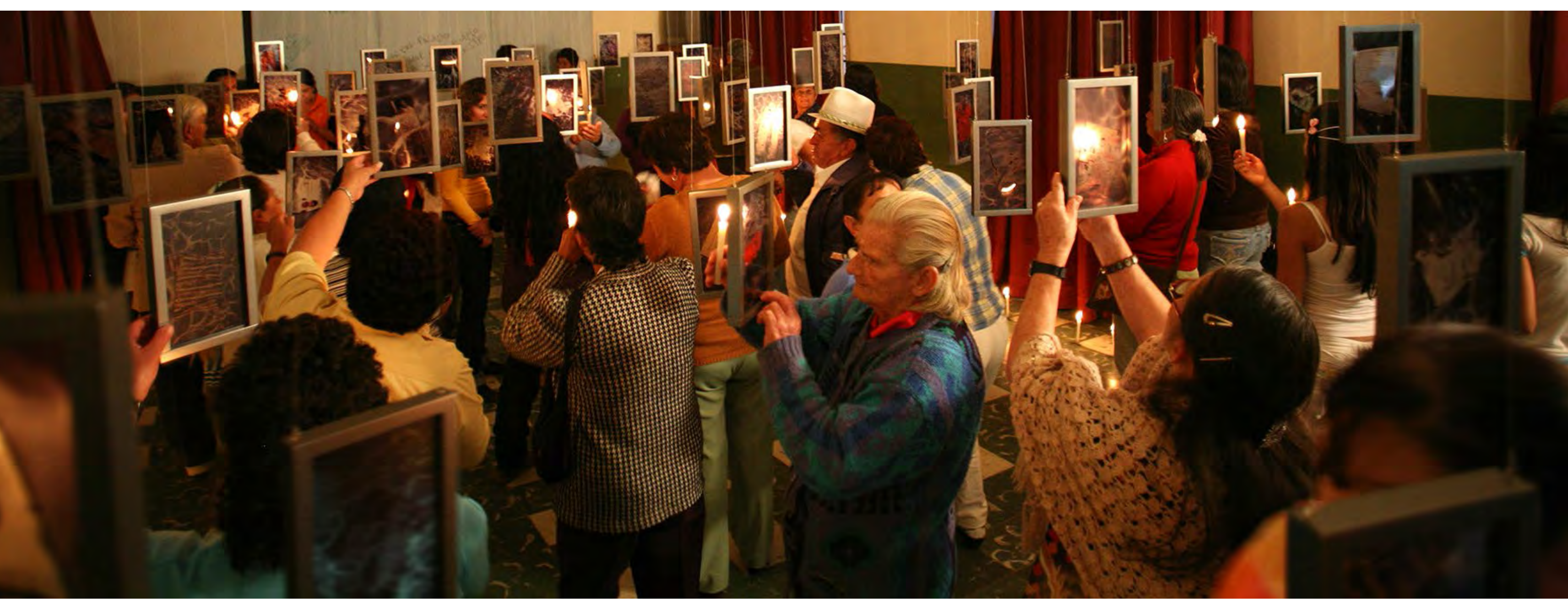



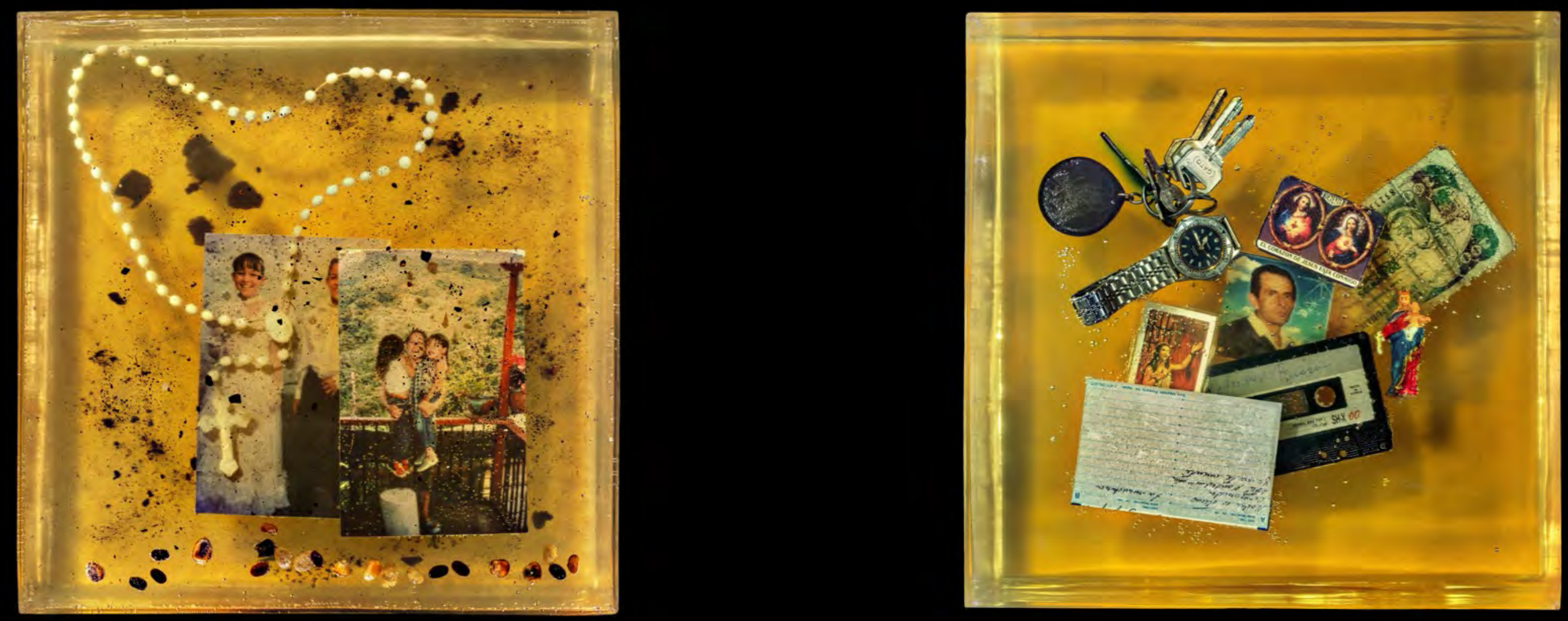


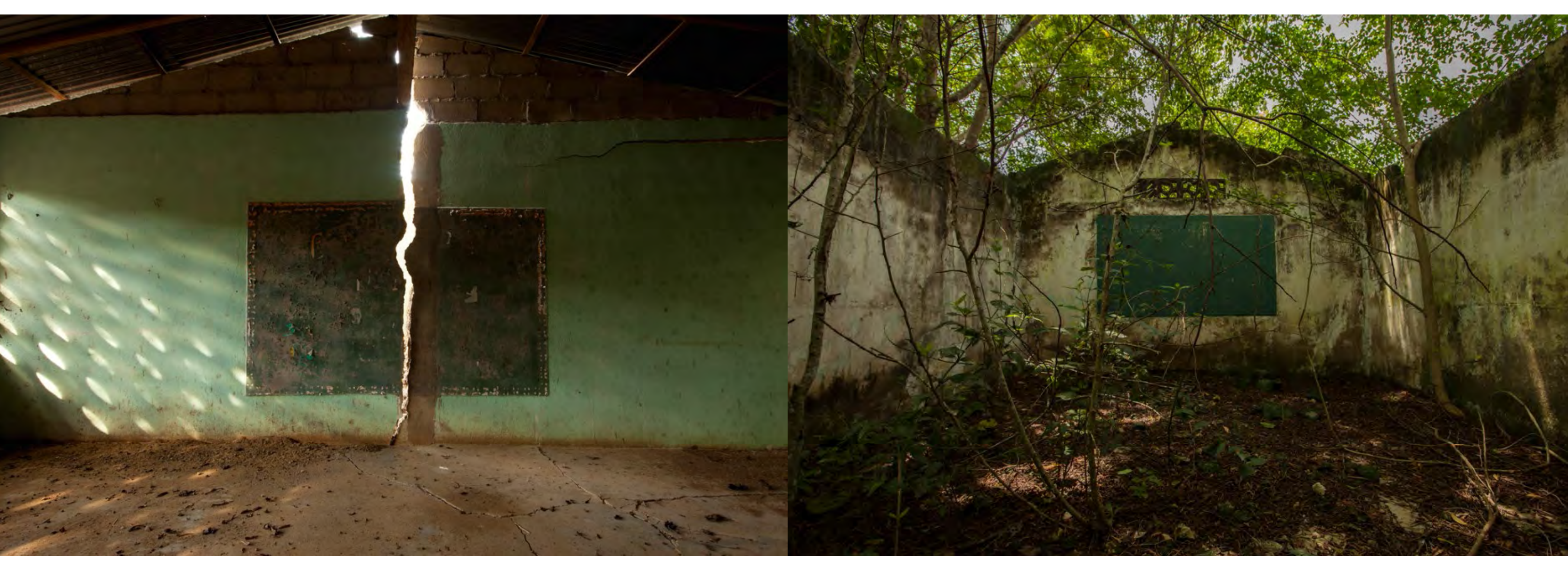




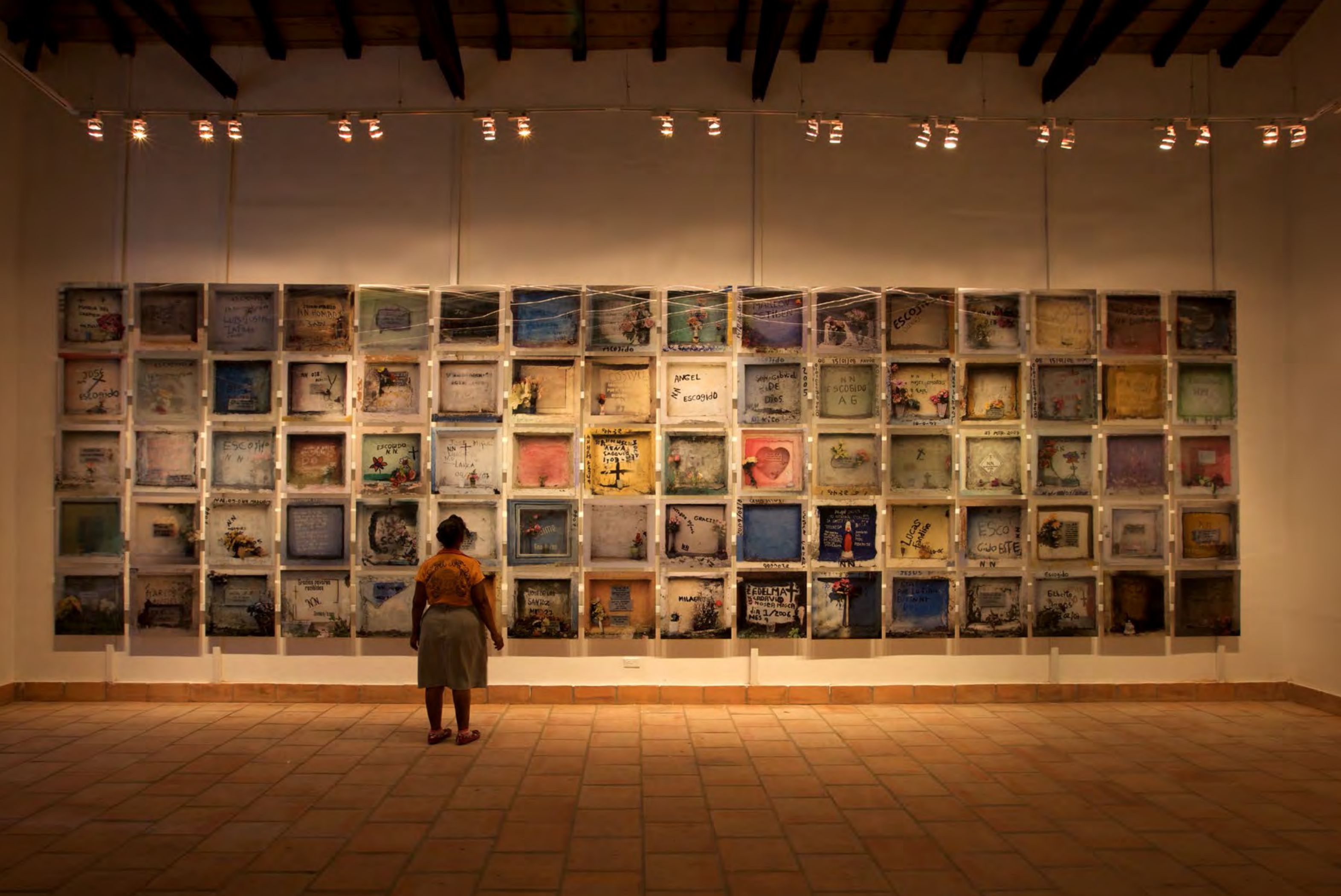



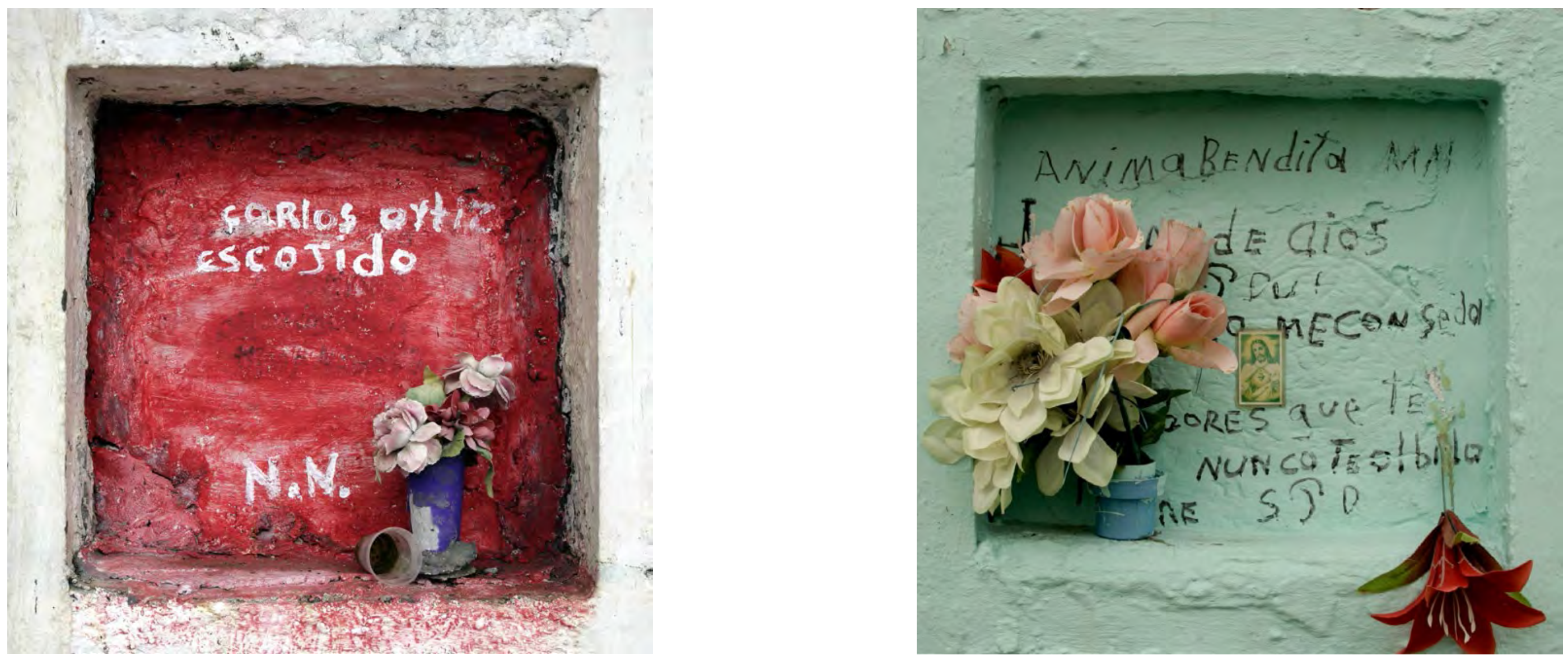


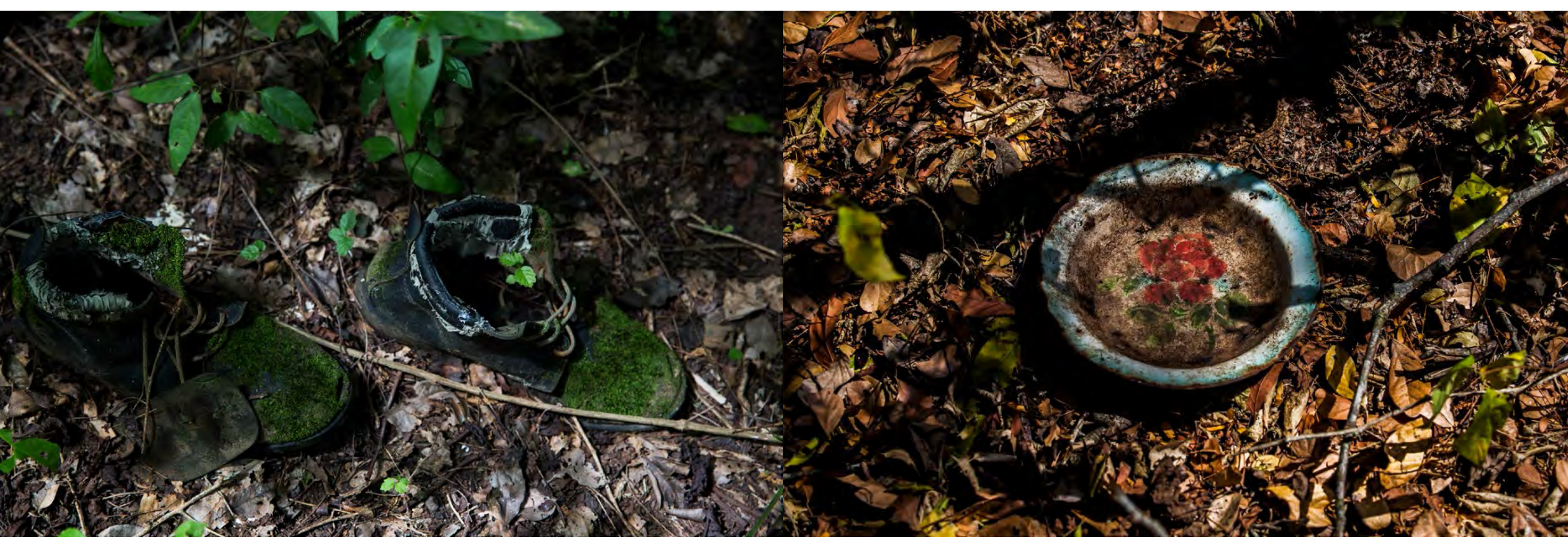




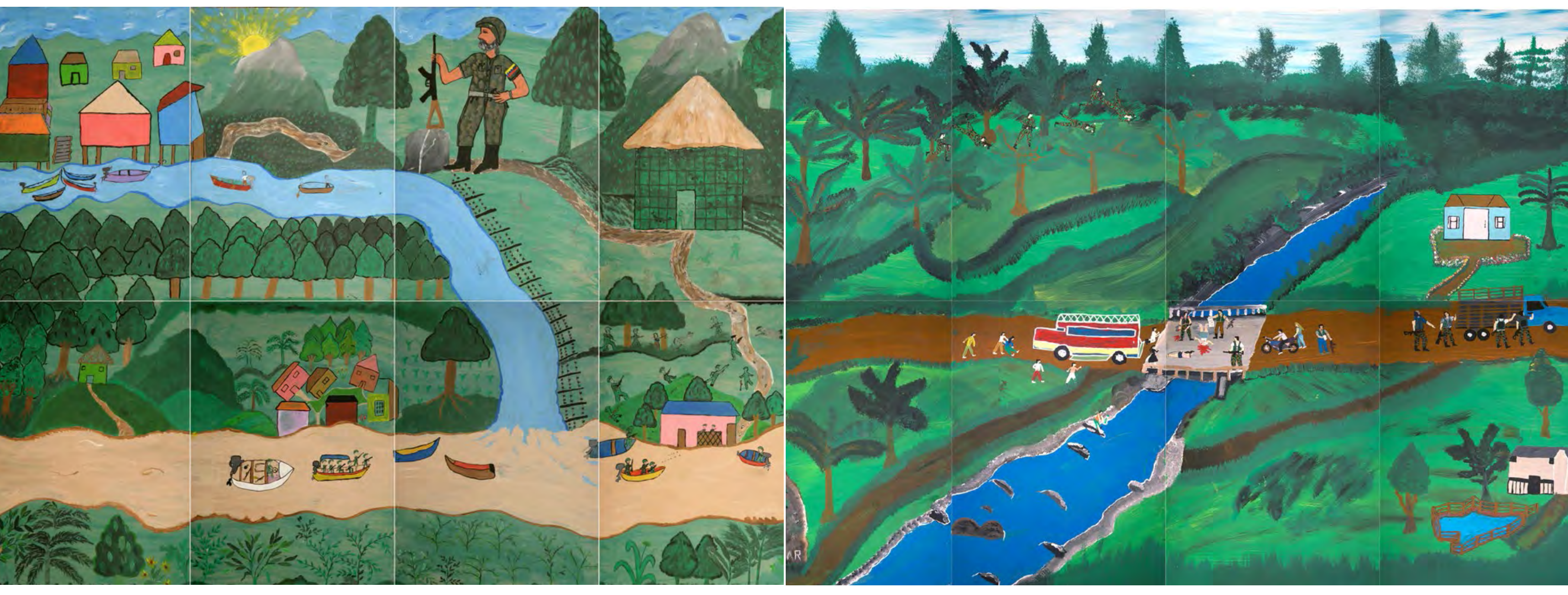



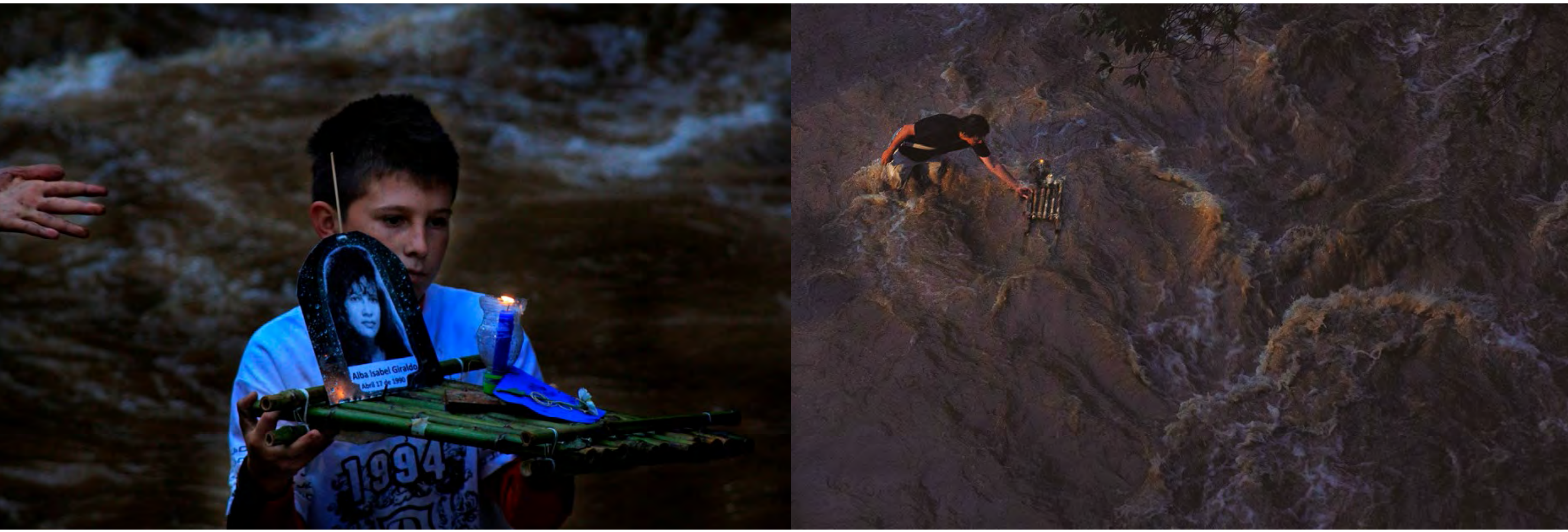

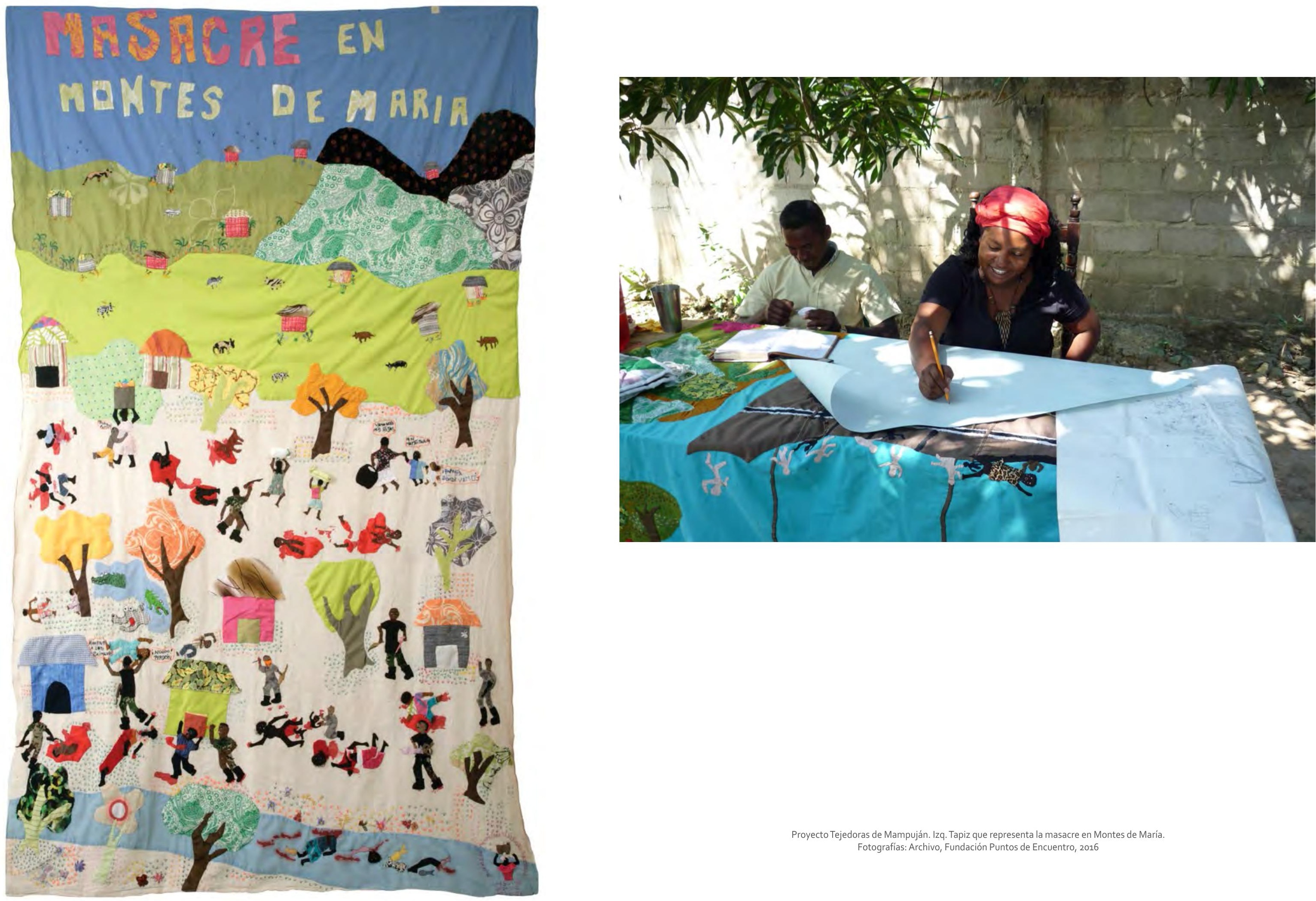


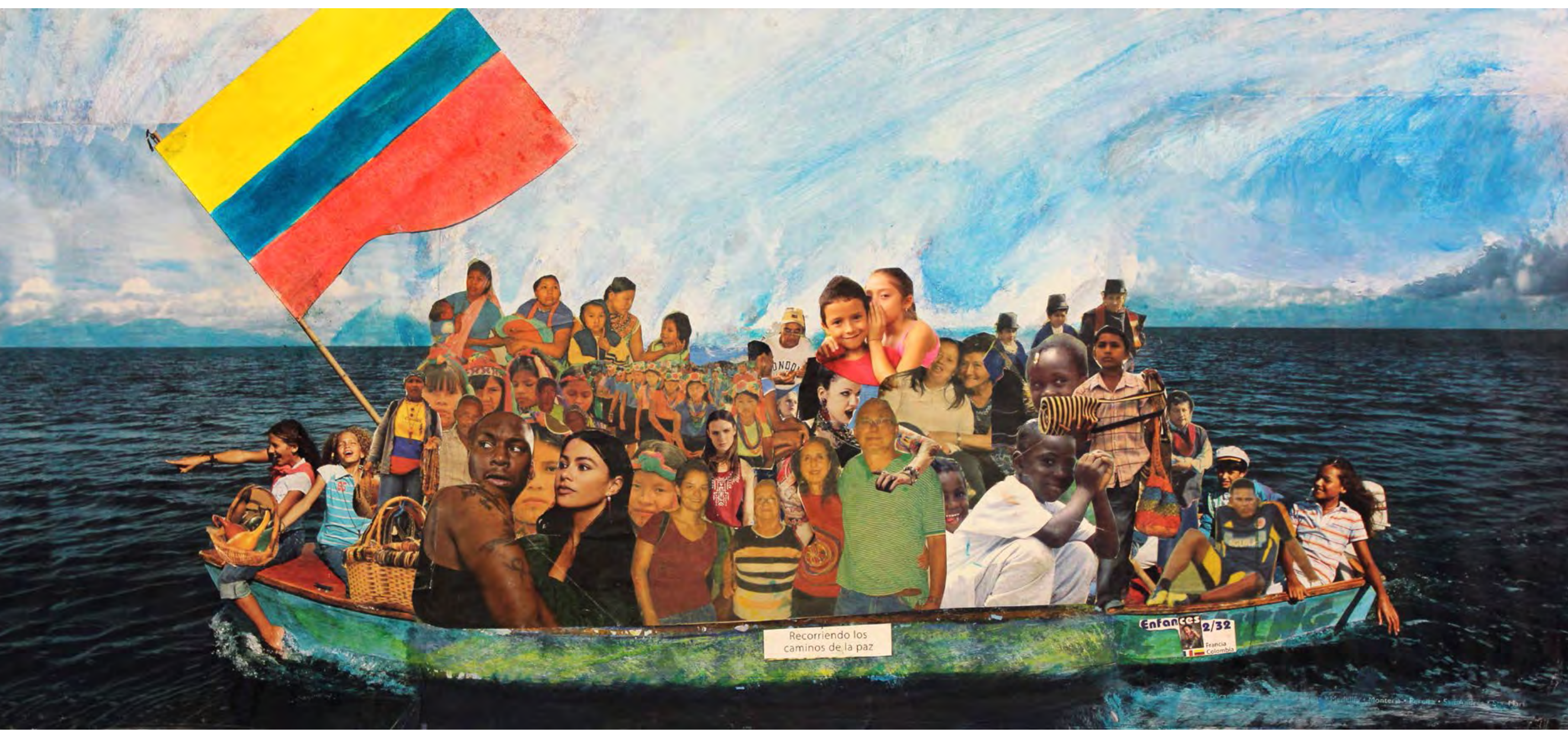



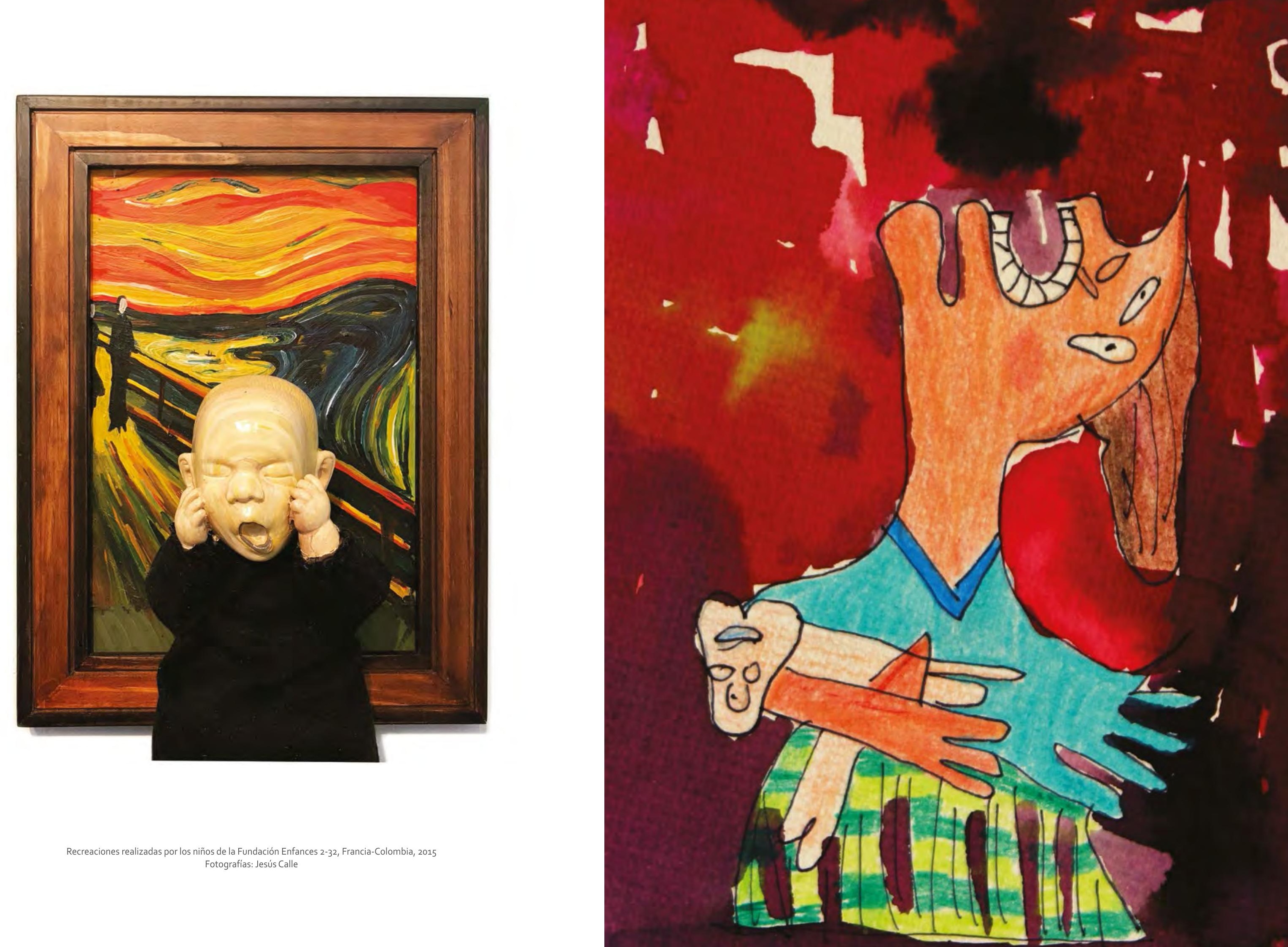


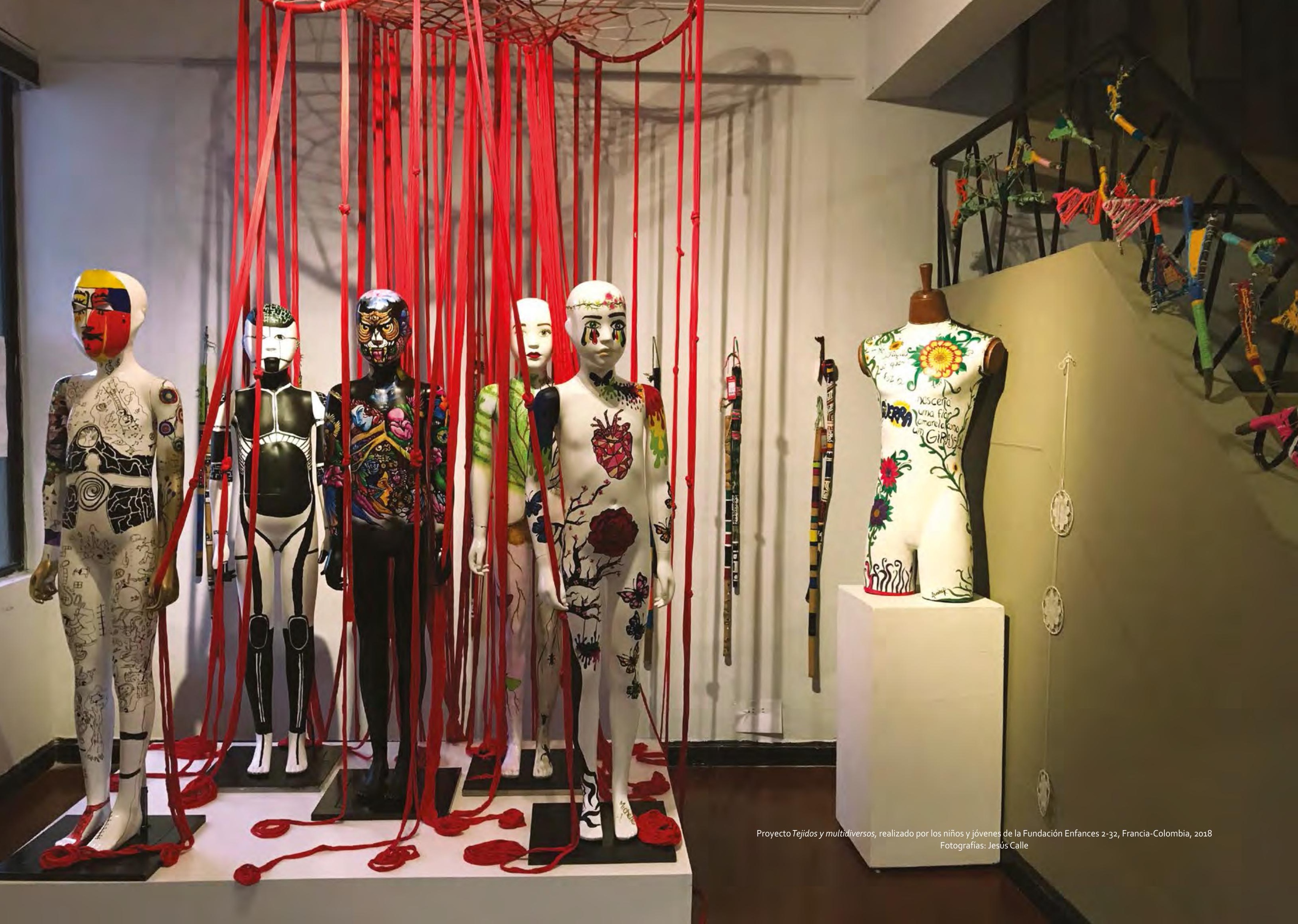




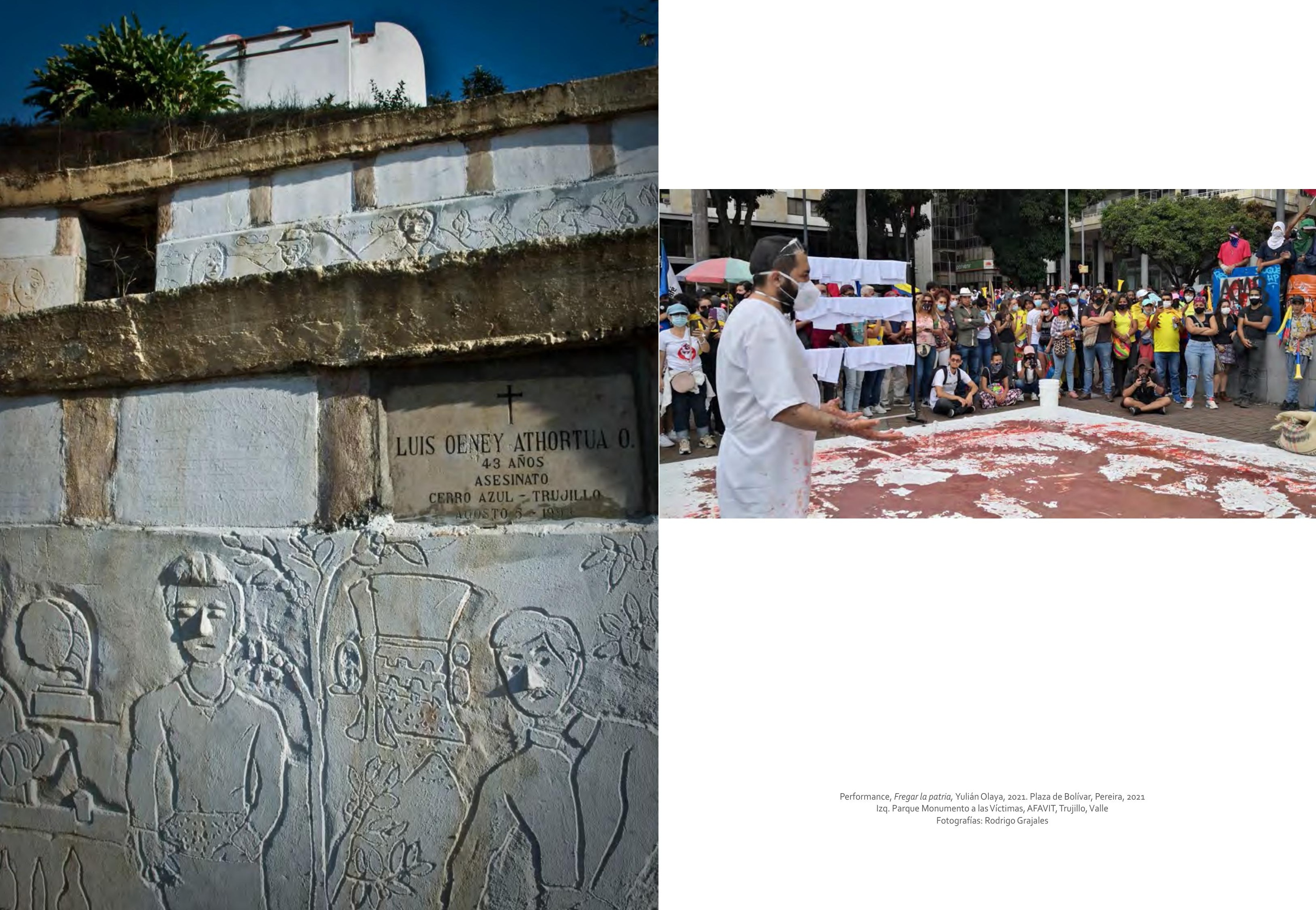




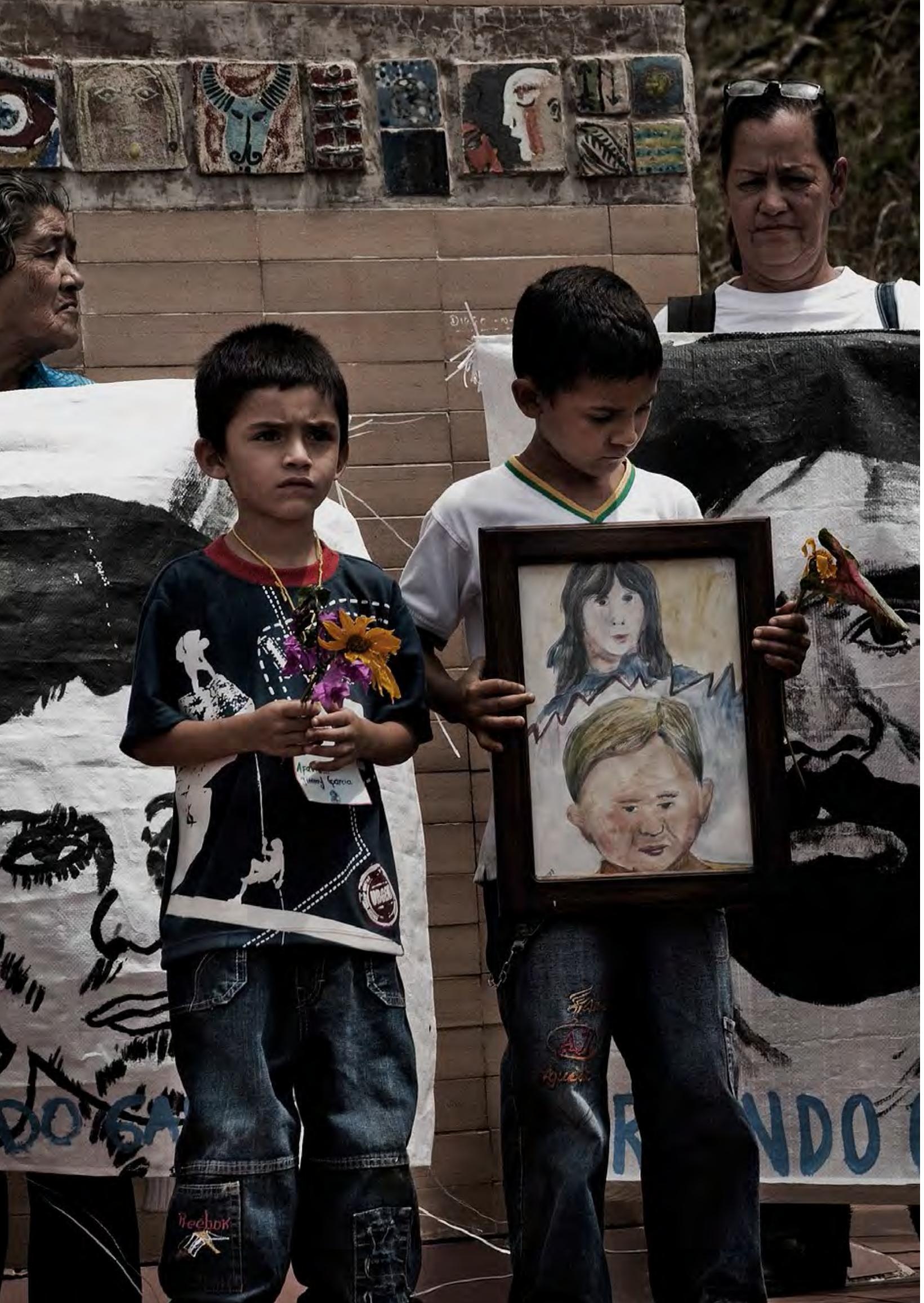

\section{Expresividades de la memoria}

La violencia como dispositivo creador

Juan Manuel Martínez 
El rol del arte en la coyuntura actual de Colombia - periodo llamado de posconflicto, o mejor, de posacuerdo de paz-, es el de recordarnos quiénes somos, en cuanto seres emocionales, racionales y sociales. De la misma manera, el arte se convierte en un canal a través del cual se transforman las narraciones íntimas en una voz colectiva, que denuncia las situaciones que la sociedad se niega a vivir de nuevo.

J. Carvajal, (2018)

Algunas de las miradas de las víctimas del conflicto armado colombiano obedecen a construcciones que asumen como campo de despliegue y visibilización los recursos expresivos y estéticos. A partir de ellos, hablan de su experiencia con el pasado y construyen vínculos de actualización para sus memorias que adquieren gran sentido en el contexto de una guerra que no termina.

A lo largo de este texto se presentan algunas experiencias de traducción y mediación de la experiencia de la violencia, desde la perspectiva de artistas y creadores que han reconocido en los dispositivos sensibles de las prácticas estéticas y artísticas, posibilidades potentes para resignificar el pasado. También se hace evidente el accionar de distintos actores sociales que han encontrado en los procesos expresivos un campo de convergencias propicio para agenciar las complejidades que entrañan la vivencia y la superación de situaciones dramáticas ligadas a prácticas como el desplazamiento forzado, la tortura, los asesinatos colectivos, el desarraigo, entre otros; así como la tarea de implementación del Acuerdo de Paz firmado entre el Estado colombiano y la guerrilla de las Farc.
La mirada concreta desarrollada en este capítulo aborda el papel de las mediaciones expresivas desde la perspectiva de las víctimas, entendiendo sus elaboraciones cotidianas como producciones estéticas, tal como sucede con los diarios, tejidos, dibujos, puestas en escena, narraciones orales, etc., las cuales tramitan elementos anudados a la violencia, en donde la ritualidad dispuesta no implica solo el hacer, es decir, elaborar, tejer, construir, diseñar, representar un objeto, una escena o una forma artística, sino también disponer toda una performancia social que proyecta, de forma consciente o inconsciente, elementos transversales que hablan de la forma de asumir, entender o enfrentar su experiencia vital con el pasado.

\section{De la representación al ritual}

Identidad colectiva, enajenación social, aceptación, apropiación, cohesión, resistencia, representación social, son algunos de los efectos que se producen a partir de las dinámicas sociales que ejecutan las comunidades. Estas se pueden construir, afirmar o rechazar, gracias a prácticas públicas como ceremonias, conmemoraciones, reuniones, rituales o hábitos, los cuales dotan significados para dar sentido individual o colectivo a personas o grupos en entornos específicos.

Tales procesos operan como mediadores tácitos o explícitos, ya sea para un tránsito emocional o para los imaginarios más diversos que intervienen en la estructura psíquica o en la ideación que sobre el mundo tiene una comunidad concreta. Todos ellos construyen representaciones sociales que se mueven, conforme a la teoría de Denise Jodelet (1984), desde la hibridación en la construcción psicológica y cognitiva del sujeto, hacia la definición social y colectiva de una comunidad. Afirma Jodelet:

El concepto de representación social designa una forma de conocimiento específica, el saber del sentido común, cuyos contenidos manifiestan la operación de procesos generativos y funcionales socialmente marcados. En sentido más amplio designa una forma de pensamiento social. (1984, p. 473) 


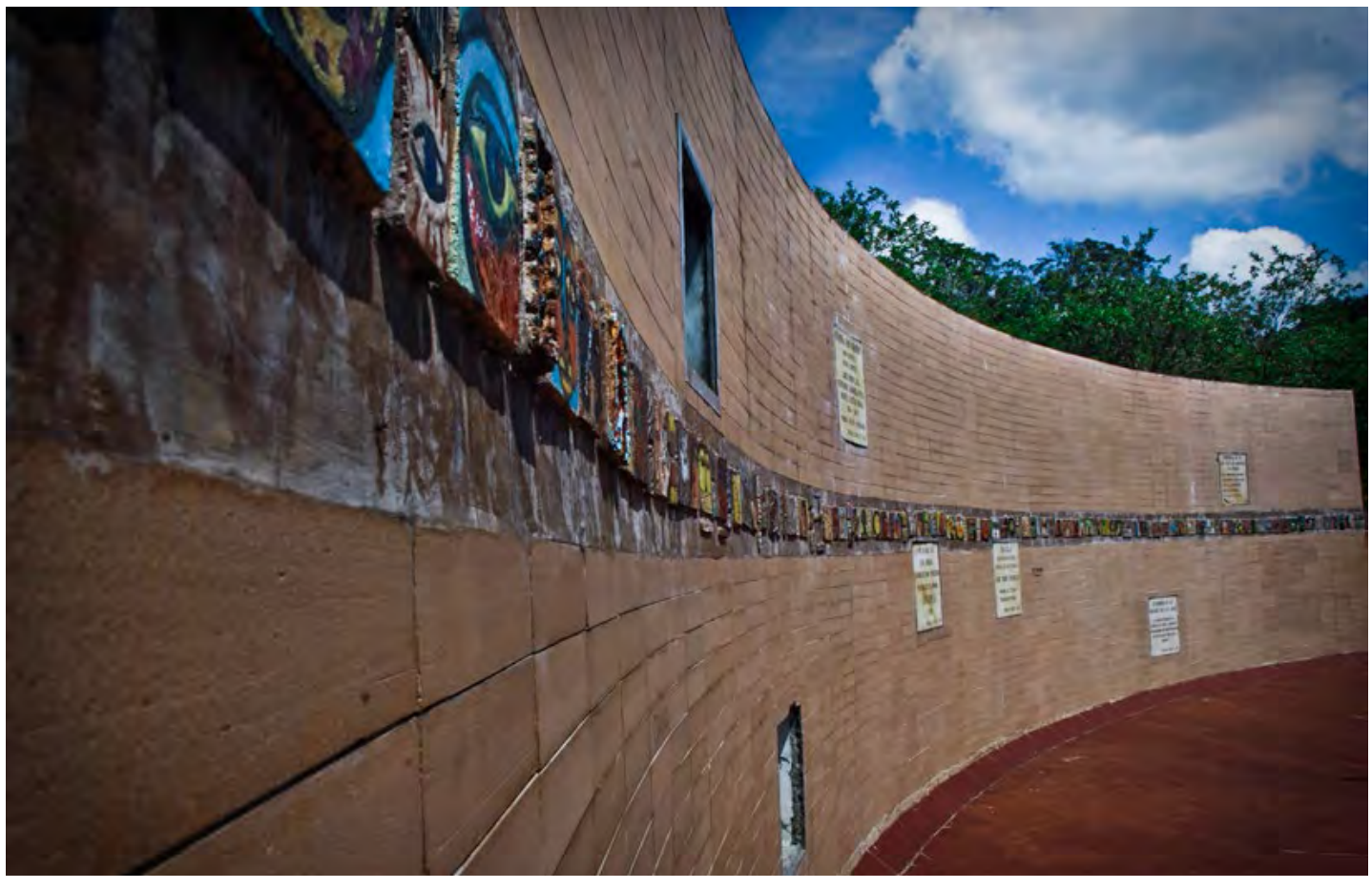

Muro del amor. Parque Monumento a las Victimas AFAVIT, Trujillo, Valle, 2020. Fotografía: Rodrigo Grajales
Para ello, Jodelet plantea cinco momentos dentro de un sistema tríadico compuesto por la objetivización, la significación y la representación social; estos momentos son: primero, el encarnado en la recepción cognitiva del sujeto; este es el espacio primario de la representación: al llegar al cerebro se genera una impresión psíquica. El segundo, la significación del proceso de representación social. Aquí el sujeto le empieza a dar un sentido a esa impresión, asignándole una jerarquía, un anclaje y un orden para él. El tercero, la representación en sí misma que éste realiza, es decir, ya es la disposición que utiliza como recurso para exteriorizar tal representación fuera de él. El cuarto, la realidad de esa representación, la práctica cotidiana, cómo convive con esta representación y cómo se encuentra frente a ella en la realidad. Por último, está la relación intergrupal que allí se genera; aquí ya se dinamizan colectivamente las diferentes puestas específicas de los sujetos.

Esta categoría es un punto de partida para entender el impacto de las acciones individuales en las representaciones colectivas de la comunidad, en especial cuando dichos comportamientos sociales van más allá de un simple encuentro transitorio con el otro. Por lo que, desde prácticas cotidianas como las usadas en códigos comunes de entendimiento a través del lenguaje, hasta las apropiaciones de emotividades o construcciones subjetivas como el miedo, la frustración o la esperanza, los actores sociales utilizan elementos que se sacralizan o se purifican por medio de acciones colectivas portadoras de sentido; en este caso, ningún asunto es exento de significante en función de una representación pública; cada elemento dispuesto ancla la idea por distintas vías; de hecho, estos elementos al pertenecer al mundo simbólico no necesariamente deben tener presencia física en la escenificación del acto o en el caso abordado por la mediación estética producida por la víctima.

La representación social se cosifica en lo que ya Jodelet llamó interacción grupal, pero su componente adquiere mayor importancia para el objeto de investigación desarrollado en el territorio posterior a ello. Aquí la mediación estética se articula como dinámica social por medio del ritual, el cual entrelaza el interés singular de un sujeto cobijado por la sombrilla de las representaciones de una comunidad de sentido, donde siguiendo la tesis de la autora, no se pierde de vista la impronta, la significación y la representación singular como puntos fundantes de su imaginario, articulados a la realidad de ésta junto con su interacción, lo que constituiría la base de toda su construcción colectiva.

Si bien la Representación social nos da un punto de arranque en la comprensión del fenómeno estudiado, la categoría central que funciona como eje en la mediación estética desde la perspectiva de las víctimas es precisamente el ritual, ya que este permite moverse entre el significado de un grupo concreto ante una acción cotidiana, junto con el significante que le otorga un individuo en un marco social por medio de una experiencia de vida específica.

Analizar el Ritual en todo su proceso permite aproximarnos a la subjetividad más allá de lo público, tal como sucede al estudiar la razón que moviliza a un artista para hablar de una guerra narrada por otros. Aquí lo protagónico no pasa por el producto final sino por toda la elaboración para llegar a este, lo cual implica convivir por meses con el drama permanen- 
te de las víctimas, interviniendo, mediando y ayudando a visibilizar una tragedia; para que, al final, todo termine en una sala de exposición ante la mirada lacerante de aquel que ve en su obra tan solo una instrumentalización del dolor ajeno; por tal motivo, el proceso ritual de artistas o víctimas permite una comprensión más amplia pero a su vez más profunda de la naturaleza de su mediación.

\section{Una revisión al concepto}

El ritual es un epicentro de inferencias cotidianas, proposiciones, afirmaciones, tesis y una muy amplia bibliografía teórica que se ha ido fortaleciendo desde años atrás; nociones como las formuladas por Durkheim en Las formas elementales de la vida religiosa (1912) empiezan a dar una mirada del fenómeno que desborda el propio campo antropológico. Ya que aquí uno de los precursores de la sociología presenta una diferenciación inicial entre tres tipos de rituales: "positivos, negativos y piaculares", explicados desde la función de éstos en el marco de las distintas estructuras sociales. Años atrás Frazer (1890) ya había iniciado una caracterización un poco más genérica del tema, diferenciando los ritos en cuatro categorías: simpáticos, animistas, dinamistas y de contagio, poniendo el énfasis en lo antropológico, pues su análisis implicaba una visión más desde la naturaleza cultural de éstos. Posterior a ello, desde el campo de la sociología Max Weber (1920) relacionó el tema con la acción racional y la intencionalidad a partir de la religión protestante, uno de los temas centrales de su obra.

Para principios de siglo XX el fenómeno ocupaba buena parte del interés de las ciencias sociales. Autores como Malinowski (1922), ya hablaban del papel funcional del ritual en un sistema de cosmovisiones que se significan a partir de los usos que las ritualizaciones tienen para distintos aspectos de la vida en comunidad. Marcel Mauss (1925) empezó a problematizar sobre su especificidad hacia el sacrificio y el lugar de la población en cada momento de la escena ritual. Mauss hizo énfasis en el tránsito de lo sagrado a lo profano del proceso y viceversa, en el marco de su "eficacia material", en especial desde el sacrificio que este atraviesa: "si se cree en el sacrifico, si es eficaz es en razón de su naturaleza social.(...) A nuestro juicio, se entiende por sagrado todo lo que cualifica a la sociedad a juicio del grupo y de sus miembros” (1970, p. 69). Meyer Fortes (1940), de otro lado, articuló este campo emergente con la necesidad de establecer su relación con prácticas tradicionales como la magia.

Posterior a ello, otros teóricos como René Girard (1972) o Max Gluckman (1976) relacionaron las significación del ritual con los imaginarios sociales. Girard con la dinámica de la violencia y el conflicto y Gluckman con el decurso del siglo XX. Ambos autores abordaron el fenómeno ya sea de manera directa como uno de sus objetos de estudio, mientras otros lo hacen de manera secular como uno de los componentes que intervienen dentro de sus campos estructurales. Tal es el caso del mencionado Malinowski, para quien el ritual tiene un lugar indispensable en la comprensión del sentido de las comunidades con las cuales han trabajado; mas sus esfuerzos conceptuales no se especifican en este campo temático.

Considerar de esta manera el ritual se da gracias a que antes para muchos era un elemento específico en un gran universo, pero hoy con la profundización que ha sufrido en el desarrollo epistemológico, se puede formular como toda una dimensión que compone múltiples universos dentro de sí.

Casos como el de Mary Douglas (1966) y sus relaciones con la purificación y marginación del proceso, o el mismo Marc Augé (1998) y los imaginarios que construye el sueño diurno en el ritual, inician un nuevo mundo de estudios del tema desde contextos específicos; lo que daría la base para que años después aparezcan abordajes mucho más contemporáneos como el de Martine Segalen (2005), quien propone el estudio de los rituales en escenarios como en partidos de fútbol, maratones, fiestas políticas y matrimonios en comunidades francesas, desde 1960 hasta la actualidad.

Aunque son muchas las definiciones que soportan estas posturas conceptuales, Segalen sugiere una que se acerca al análisis teórico a partir de los diferentes autores: "el rito se sitúa en definitiva en el acto de creer en su efecto, a través de prácticas de simbolización” (2005, p. 25), prácticas a las que Mary Douglas llama imposibles de entender si las relaciones sociales no están compuestas por actos simbólicos (1973, p. 89); actos de 
socialización simples o estructurados que ponen en juego dinámicas de diverso significado, estas dan y prestan sentido a las acciones que el sujeto construye, evidencia $u$ omite en una cadena de significantes sociales.

El ritual asume un rol que pone en relieve la estructura social desde sus elementos más simples en apariencia, como por ejemplo el orden y las normas sociales, hasta sus representaciones más complejas, como la comunicación e interacción cultural y los símbolos significantes que ésta posee. Tales características pueden ir más allá de la palabra y, al contrario, pueden encontrar en la ritualización una manera de resistencia a una forma establecida de ver las cosas.

La vasta bibliografía que posee el tema no hegemoniza un sistema único cuando hablamos de función, sentido, significado, o intencionalidad social en los rituales; esto gracias a la diversidad y complejidad que encierran, así como a la gran variedad de casos de análisis que se ha trabajado. Para la mayoría de las teorías en torno al ritual, el contexto es el primer agente mediador, ya que define las características particulares que se utilizan; empero, aún no existe plena aceptación de cuáles fenómenos específicos denominamos rituales y cuáles no cumplen los elementos para entrar en esta categoría; por ejemplo, para algunos autores los episodios de la vida cotidiana (Douglas, 1973) cumplen las condiciones sociales para entrar en la teoría de la acción ritual; para otros no, en tanto que serían solo expresiones sociales ordinarias.

Especial capítulo en las distinciones de lo que podemos entender como ritual y lo que no lo es, enfrenta las nomenclaturas urbanas no étnicas. Allí la fragilidad de la denominación de una acción como parte de un proceso ritual, se descalifica por la ausencia de símbolos o comportamientos que hagan "evidente" cosmovisiones diversas, donde la representación para algunos debe atravesar los mismos estados o por lo menos similares a los que motivaron el estudio de este fenómeno en comunidades indígenas.

En ese sentido, es importante ubicar un punto de análisis no concluyente pero sí delimitante de lo que entendemos por el concepto de ritual, al tener una tradición tan fuerte y ser uno de los ejes primarios de manifestación de cualquier comunidad. Por esta vía, el ritual es importante analizarlo si lo leemos desde la propuesta de Levi Strauss (1984), donde el mito y la celebración ritual ponen de manifiesto las características más intrínsecas de una sociedad, funcionando como catalizador de las necesidades más profundas, ya sean espirituales, políticas, instintivas, etc, en busca de un tránsito, un paso o una liberación, representando el sentido social y desplegando un arsenal simbólico en todo su proceso. En palabras de Víctor Turner (1988):

Un ritual es una secuencia estereotipada de actos, que comprende gestos, palabras, objetos, etc. celebrado en un lugar determinado con el fin de influir en las fuerzas o entidades sobrenaturales en función de los objetivos e intereses de los que lo llevan a cabo -actores del ritual-. (p. 21)

Siguiendo a Turner, este permite ese diálogo dinámico, donde una comunidad deja ver sus tradiciones de manera jerárquica, organizada y estructurada o de forma más efímera y circunstancial, pero dando muchas veces valor a un juego de emotividades y sentimientos que se dejan ver con diferentes sistemas simbólicos; se señala de esta forma una semántica entre los participantes del ritual, los símbolos que lo conforman y el significado que este busca, poniendo en relieve ese "drama social", que habla desde el fondo de las paradojas y deseos de un grupo determinado.

El ritual, así, tiene la virtud de no obedecer a lógicas de dominación únicas y puede emerger como resultado de oposición, necesidad o re-significación del espacio. Ciertas prácticas de esta forma se pueden convertir en la cotidianidad en un ritual, cargado de significaciones, intenciones conscientes o inconscientes, de pequeñas narraciones o expresiones sociales indispensables para la convivencia de un grupo determinado de personas. Por ello, el ritual no se puede entender exclusivamente como una práctica ceremonial de una gran puesta en escena, o un dispositivo exacerbado y vistoso, sino como una expresión portadora de sentido, con códigos básicos, pero con representaciones complejas de elementos que, a simple vista, son cotidianos y pasajeros. Mary Douglas expone:

Los ritos sociales crean una realidad que no pueden subsistir sin ellos. No es excesivo decir que el rito significa más para la sociedad que las palabras significan para el pensamiento. Pues es muy posible entrar en conocimiento de algo y hallar luego palabras para ello. Pero es imposible mantener relaciones sociales sin actos simbólicos (1966, p. 89). 
Una de las acepciones fundamentales para comprender este fenómeno, lo desarrolla Segalen, respecto a los rituales contemporáneos, "se abre una perspectiva desde la que se perciben como ritos, en la medida en la que ordenan el universo cotidiano, algunos gestos que sin embargo nos parecen ordinarios" (2005:17). Por tal motivo entre la complejidad y la cotidianidad es que se mueven estas disposiciones rituales en un espacio y en un tiempo determinado.

La mediación estética de la víctima,

el ritual como recurso simbólico

Propongo cambiar por: Aproximarse a la comprensión del papel del ritual en los procesos de mediación de las víctimas sobre su experiencia del conflicto armado, implica reconocer los recursos simbólicos y las trazas sensibles que se proyectan en la configuración de sus memorias. Sus momentos posibilitan una revisión íntima de la experiencia vivida a través del tiempo, un antes, un durante y un después, van caracterizando un relato emergente que habla de la memoria de las víctimas, la memoria del conflicto colombiano, la memoria de la guerra; pero ante todo, hablan a través de aquello que en términos metodológicos no va aflorar por medio de las palabras, sino que requiere otros medios simbólicos para manifestarse.

La ritualidad representa una construcción comunitaria, evidencia la estructura política que posee un grupo, hace alusión al orden, al rol, a las jerarquías sociales, a las distribuciones colectivas; despliega, por medio de una práctica consensuada, la radiografía de un grupo social desde sus formas simbólicas de representar y ordenar el mundo. De igual forma, el ritual se puede expresar de forma individual por medio de elementos conscientes o inconscientes; un sujeto utiliza esta performancia social como recurso a través de prácticas que repite cuidadosamente en su entorno, las cuales dicen algo de sí. Igual sucede con los rituales colectivos, la manera como este organiza su mundo desde sus elecciones, disposiciones, deseos y/o preocupaciones que encuentran en el acto ritual un recurso simbólico para enfrentar o anudar su experiencia espacio temporal de forma específica.

En ambas situaciones, ya sea de manera individual o colectiva, la ritualidad permite una representación dinámica del rol de los actores sociales, tanto así que la ambivalencia en las jerarquías termina siendo un componente fundamental para el desarrollo de estos procesos que en la escenificación de las prácticas realizan movimientos de sus disposiciones y lugares ocupados en la cotidianidad; así como de las normas y los códigos que establecen entre lo permitido y lo censurado al interior de un grupo.

En este proceso, que Turner (1988) dentro de la teoría clásica del Ritual denominó “inversión de roles", se entiende el paso de un estado al otro por medio del tránsito de una condición dentro de una estructura social a una diferente, el camino hacia nuevos lugares, inesperados, cómodos o no, pero distintos de sus comportamientos habituales. La definición exacta, en términos conceptuales, siguiendo a Turner, es la de liminalidad, concepto usado inicialmente por Van Gennep (1985), quien lo utiliza por primera vez para hablar de los saltos de una condición particular a una nueva. Edmund Leach (1977) también lo usa para comprender prácticas contemporáneas. En ambos se conserva el carácter afirmativo de la estructura social, es decir, no problematizan en lo que Turner denomina cuestionamiento a la estructura social o antiestructura, lo que se da por medio precisamente de la liminalidad a través de la mencionada inversión de roles, categoría que termina siendo capital en todo el desarrollo epistemológico de lo que analiza éste desde el fenómeno mismo del ritual.

Para el trabajo de investigación realizado, la liminalidad es el punto de conjugación de la escena ritual, en donde es fundamental ubicar esta categoría desde una distinción temporal, un antes (preliminalidad), un durante (liminalidad), un punto ciego, la máxima manifestación del acontecimiento (limen) y un después (posliminalidad). En ese sentido se asume la noción de liminalidad como ese momento en el cual la mediación estética es expuesta, sin saber qué se puede encontrar; es el punto de irrupción que marca el trazo de un estado previo a un estado posterior, el momento en donde se conjuga la intención misma que los convoca dentro de una práctica específica. 


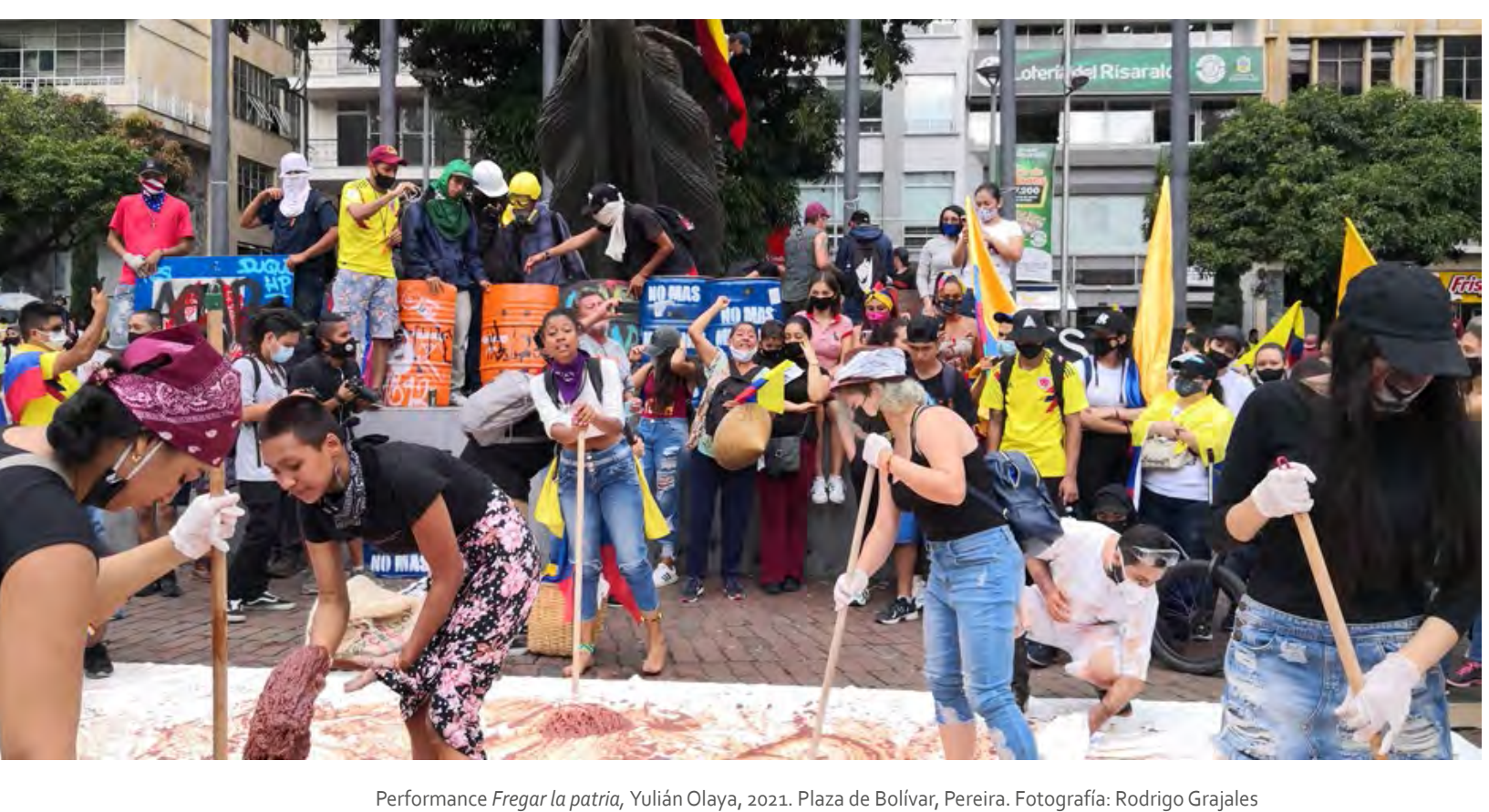

Aquí se trabajó con el testimonio de diferentes víctimas del conflicto armado, por medio de entrevistas semiestructuradas, diarios de campo y diseño documental; se parte del hecho de que ellos al igual que los artistas son mediadores estéticos del conflicto; esto por medio de diversos elementos tales como la pintura, la poesía, el teatro, diarios personales o por medio de relatos al testimoniar su experiencia. Esta información se analiza a partir de la categoría ritual y sus distintos momentos, sin dejar de establecer vínculos con la noción de liminalidad.

Yulian, que ha sido víctima del conflicto desde niño; intenta de forma simultánea, evocar y resignificar su experiencia a través de la mediación de una acción artística, en la cual, dispone elementos simbólicos y gestualidades concretas. A pesar de que en un inicio, en el acontecer del diálogo, dice no saber cuál es su intención específica, termina aclarando que lo que motiva su intervención es transmitir a otros su perspectiva de lo que sucede en el país.

A partir de allí el ritual puede ser un medio por el cual se puedan sacar inferencias más claras dela mediación que su práctica estética produce en relación con su pasado, particularmente porque desde este se pueden evidenciar algunos de los elementos subjetivos que se escapan al orden de su discurso y se mimetizan en la elaboración, ejecución y expectativa de repetición de la práctica, en este caso artística.

Inicialmente se obtura la mirada sobre la ritualidad del proceso creativo. Se le indagó a Yulian por la sensación al momento de presentar una obra, en donde señalaba a propósito de una puesta en escena realizada en el hall central de la Universidad de Caldas en el año 2017: "Ese performance fue como un grito. Porque la gente pasaba, olía la sangre, una cosa bien particular". Aunque insiste en el elemento transgresor y participativo del público en su obra, cosa que no esperaba, llevó su reflexión a la elaboración previa (preliminalidad), en donde señalaba que sintió que el ritual mismo inició antes de lo que él había pensado; esto sucedió cuando fue a recoger el material que iba a disponer para el acto:

Yo no contemplé que tenía que ir por la sangre; por eso digo que el performance empezó desde ese momento de ir al matadero. Yo fui con un parcero, entramos y era particular porque llegaba gente a comprar sangre para alimentar a los animales, la usaban como concentrado. Pero a ellos se los empacaban en carrotanques, y yo llevaba bolsas debasura. Entonces un muchacho, ya cuando nos tocó el turno, empezó a llenar esas bolsasy cada vez que cerraba una, la llave seguía abierta y nos caía sangre a nosotros. (Diálogo con Yulian, autor del performance, 2017)

En este caso, el hecho de que aparezcan diferencias entre lo proyectado y lo experimentado, es sintomático en escenas rituales tan previamente planificadas. No era la primera vez que se presentaba este performance, tampoco la primera experiencia en su organización. Pero la fragilidad de la liminalidad moviliza al sujeto en virtud de roles que cambian y lo vuelven, asimismo, espectador de su propia obra; así como su condición de víctima se re-edifica en escenas rituales pero no por ello deja de sorprenderlo en la construcción misma de este proceso. En ese sentido se asume que Yulian al decir que el performance fue como un grito, está quizá más bien haciendo una alusión de él mismo, de su propia voz, de su propio grito.

Es importante aclarar que la complejidad de las escenas rituales lleva a que el salto del significante primario se encuentre albergado en el punto liminal, pero los elementos pre y pos configuran criterios tan importantes 
como éste a la hora de analizar todo el proceso. Es por tal razón que en el caso abordado se le otorgó bastante importancia en el momento previo, a pesar de que habíamos ubicado el punto de reflexión en el instante concreto de liminalidad.

Un ritual definido como de paso o de tránsito, no es exclusivo de escenas altamente elaboradas o con preparación muy compleja, ya que como se ha mencionado, este también puede ser una práctica puesta en situaciones cotidianas, a la manera como lo trabaja Douglas (1966), o en ámbitos más íntimos como el cuerpo y su teatralidad en la interacción social, como lo desarrolla Goffman (1956). Precisamente, el análisis que hace Marta Rizo sobre este último permite ver la evolución de su obra hacia una lectura simbólica del contacto con el otro en intercambios transitorios:

Desde su perspectiva, más que un suceso extraordinario, el ritual es parte constitutivade la vida diaria del ser humano, por lo que se puede decir que la urdimbre de la vida cotidiana está conformada por ritualizaciones que ordenan nuestros actos y gestos corporales. En este senti-

do, los rituales aparecen como cultura encarnada, interiorizada, hecha cuerpo, cuya expresión es el dominio del gesto, de la manifestación de las emociones y la capacidad para presentar actuaciones convincentes ante los otros con quienes interactuamos. Las personas muestran sus posiciones en la escala del prestigioy el poder a través de una máscara expresiva, una 'cara social' que le ha sido prestada y atribuida por la sociedad, y que le será retirada si no se conduce del modo que resulte digno de ella; las personas interesadas en mantener la cara deben de cuidar que se conserve un cierto orden expresivo Goffman, (1956) (...) el ritual es un complejo de símbolos, pues transmite información significativa para otros. (Rizo, 2011, p. 83)

De esta manera, las acciones que ejecutamos en la vida cotidiana, pueden ser comportamientos normales sin mayor riqueza simbólica o pueden constituirse en un campo semántico cargado de significantes que dicen algo de nosotros o de nuestra comunidad de sentido. Hugo, víctima del asesinato de su abuelo en Carepa, Antioquia, a causa del despojo de tierra y posteriormente víctima del desplazamiento en 1994 en Chigorodó, Chocó, por causa del paramilitarismo, encontró una mediación estética precisamente en la escritura, como una práctica cotidiana. Ella constituye su recurso simbólico más significativo para enfrentar el pasado y asumir una posibilidad de futuro por medio de este ejercicio dinámico.

En el desarrollo metodológico, al volver sobre la liminalidad, se le formula a Hugo la misma pregunta acerca de su sensación, percepción o interpretación del instante más protagónico del proceso de escritura, aclarando que él mismo identifica la temporalidad del ejercicio. Ante el interrogante señala: "es un orgasmo. Es una sensación placentera, literalmente un coito. En el sentido también de que uno se expande, uno siente esa tranquilidad. Un texto es un parto". La insistencia en el gesto liberador implica un quiebre con una cotidianidad en donde no se puede tramitar esa experiencia por otra vía; para ello se asume un rol que se puede tornar imposible en lo biológico pero que por medio de la mediación literaria define la experiencia subjetiva de que aquello parece no tener forma de describirse, sino como metáfora, es decir, representación interesante de una inversión del rol masculino, en una víctima que encontró su talento estético en la mediación con las palabras.

A pesar de la inversión del orden "natural” utilizado por Hugo para explicar el efecto de su propio proceso creativo, este conserva cuidadosamente una organización en su creación escritural, lo que en el caso del ritual, Saúl Millán denomina la "sintaxis ceremonial”, caracterizada por el orden, la finitud y las variables contempladas:

La existencia de un acervo reducido, circunscrito a un número específico de series y unidades, resulta inherente a una actividad simbólica que, como el ritual, opera sobre la base de continuas repeticiones. Si

el acervo de procedimientos rituales fuera infinito y estuviera sujeto a una innovación permanente, las comunidades se verían en enormes dificultades para reproducir durante cada ciclo el esquema ceremonial. (Millán, 2008, p. 65)

En este caso, la sintaxis ceremonial inicia con el orden, las variables y los límites desde una subjetividad que, como millones en este país, se encuentra atravesada por la historia política de los últimos 60 años; primero, se trata de una experiencia de violencia producto del conflicto armado, el despojo y la lucha por el control territorial. Segundo, supone una búsqueda o necesidad de mediar, "tramitar" con una apuesta estética propia, lo 
que, en palabras de Hugo, "es mera catarsis hermano". Tercero, potencia un significante (variable) especial que para Hugo se concentra, en buena medida, en la experiencia femenina del dolor y el suplicio;de ahí la importancia de la metáfora del parto, como parte de su experiencia traumática:

Estoy indagando acerca del elemento femenino. Es un gran reto. Con mi pasado... yo pienso que es que nosotros hemos mirado la Historia desde la visión de hombre, y creo que ha hecho falta un poco el Enfoque de Género; para mí, en este momento, es necesario mirar la violencia desde el cuerpo de la mujer, porque pienso en mi mamá; pienso en mis tías. Hay una escena que a mí no se me olvida, viejo, para mí esa escena es...(silencio) yo vi el cuerpo de una mujer empalada, y yo era un niño (silencio). Y nosotros como colombianos, si queremos aportar a la paz, necesitamos ese tipo de enfoque. Y para mí ahora en un cuento que estoy trabajando, significa esa pregunta, ese seguirse preguntando. (Hugo, entrevista 2)

Todo esto da como resultado que su obra esté concentrándose en buena medida al tema de la feminidad en la guerra como impronta, debido al lugar que ocupa su actividad simbólica desde el pasado y la necesidad de recrearlo como mediación desde el presente.

Su despliegue liminal se presenta en lo que Millán (2008) va a denominar como la semántica del símbolo, pues se pasa de tener un acto de creación-mediación-estética, que conserva una estructura ritual -así lo señala Turner- a un giro en el rol y la subjetividad del artista. La semántica implica, siguiendo a Roland Barthes, que estos "significados están íntimamente relacionados con la cultura, el saber y la historia” (1970, p. 105). En el caso abordado se requiere entender la experiencia particular del artista, el acumulado histórico vuelto un saber de las víctimas de la violencia política de Colombia y el dispositivo cultural que en el presente le sirve como intermediario estético para resignificar el pasado.

La creación, en el primer caso, trabajada desde el performance de la víctima, vehiculiza formas distintas de habitar y habitarse en la cotidianidad, anudada al deseo de liberar un testimonio por medio de símbolos y representaciones. En el segundo relato de la experiencia es profundamente corporal; se relaciona también con la posibilidad liberadora, trascendente y tensa entre el dolor y el placer que envuelve al sujeto con su mediación.
El valor social que implica que las víctimas encuentren formas más íntimas para expresar estéticamente su elaboración del pasado, a diferencia de los artistas que necesitan dispositivos más complejos, no se limita a un sujeto creador-mediador, sino también a su posibilidad de hacer pública la subjetividad contenida de un actor que puede Salir, por medio de este proceso, de su marco cotidiano. Lo valioso está en irrumpir con su hábito y con el correcto comportamiento que le demanda ser parte de una estructura; de igual forma constituye la posibilidad de disponer del mismo cuando se trata de rituales individuales, una apuesta estética que "hable" de su comprensión del lugar ocupado desde la experiencia, en donde reproduce lo que quiere narrar o lo que precisamente no desea o no puede hacerlo de forma consciente y donde se convierte el ritual de elaboración en el escenario que aloja un síntoma emergente que aflora, sin ser esa la intención.

Estudiar los rituales como recursos simbólicos, le permite al sujeto dinamizar síntomas vinculados a su pasado. Estos pueden implicar, con el tiempo, llegar a un trámite por el efecto catártico de exteriorizar y nom-

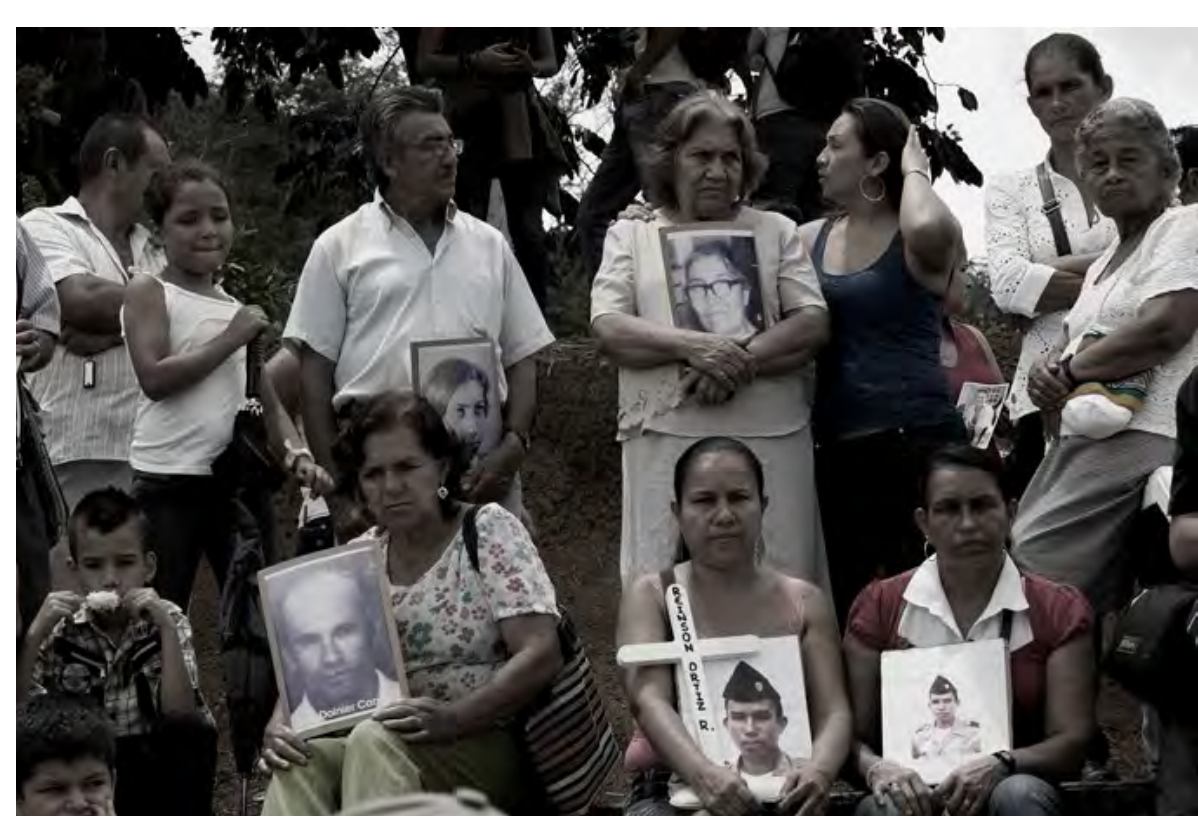

XIII Peregrinación Nacional en memoria de las victimas, AFAVIT, Trujillo, Valle, 2013. Fotografía: Rodrigo Grajales 
brar la experiencia dolorosa; pero de otro lado también puede ser un mecanismo de protección de las víctimas para contener significantes dolorosos que se quieren olvidar y que al perdurar en el tiempo, se integran en su subjetividad, gracias a la imposibilidad de olvidar lo inolvidable.

Jhonathan, un joven desplazado de una zona controlada por la insurgencia, señala, a propósito de lo que busca su obra poética desde su lugar como víctima:

Cuando intento hablar de aspectos sociales, conflicto $\mathrm{u}$ otros relacionados, algo me lo impide de la manera en que yo quisiera, entonces lo guardo. Siempre lo guardo, lo pospongo. No sé si es miedo, temor. Pero aún no me siento con toda la libertad para decir lo que quiero decir. Aún no he sido capaz de abordar con amplitud un trabajo que ahonde en $\mathrm{mi}$ relación con el conflicto, con la guerra. No sé por qué no he sido capaz.

Sí he hecho algunas cosas, pero en el fondo sé que debo decir, contar lo que he vivido, lo que ha vivido mi familia, pero aún no es el momento.

Aún me cuesta hablar de esas cosas. (Jhonathan, Entrevista 4)

Las prácticas rituales establecen distancias entre lo que se piensa, se dice y se hace, ya que la ritualidad no debe ser necesariamente un acto plenamente consistente entre estos tres elementos. Gran parte de su función está en el hecho de mimetizar o representar lo que se asumía como irrepresentable o lo que no se quería decir o reconocer en el lenguaje.

Jhonathan es muestra de ello, pues la recurrencia en su relato sobre la imposibilidad de hablar del conflicto no se mantiene y ya al final de la entrevista realizada reconoce cómo su historia vinculada a la violencia política y social está plasmada en toda su obra; es un elemento inherente que se despliega en todos sus escritos, particularmente el deseo de narrar el pasado desde su propia tristeza: "Quien lea mi poesía o mis artículos de prensa (crónicas, etc.) encontrará cierta nostalgia, desasosiego, por lo que ya no está, por lo que se ha ido". Es por eso que la mediación es un juego entre el deseo de lo que se quiere expresar y la emergencia de eso que se relata sin querer.

Volviendo con el caso de Yulian, de quien ya habíamos mencionado de paso su significado con la preparación preliminal y liminal, es importante entender que él se define como artista, docente y víctima del conflicto armado, pero habla poco de su experiencia de vida por medio del testimonio oral. Su mediación con lo vivido está representada de forma clara, realista ycruel en su performance Fregar la patria, donde su escena ritual en la elaboración de todo el proceso muestra el camino del relato al símbolo como mecanismo tácito de manifestación con la violencia política del país.

El ritual como práctica política que narre o manifieste un lugar con la violencia en Colombia desde la perspectiva de las víctimas, como lo mencionado con Yulian, implica el accionar de sujetos que disponen de un interés, una voluntad y ante todo, de una consciencia de lo que procuran realizar.

Empero, otras construcciones más asociativas, no tan individuales, se manifiestan en actividades como misas comunitarias, movilizaciones, teatralización de lo vivido, entierros simbólicos, marchas exigiendo justicia y reparación integral, etc. Propuestas que empoderan la crisis subjetiva y la dirigen hacia una apropiación política comunitaria por medio de estas prácticas que, con el tiempo, gracias a la consistencia y la repetición per-

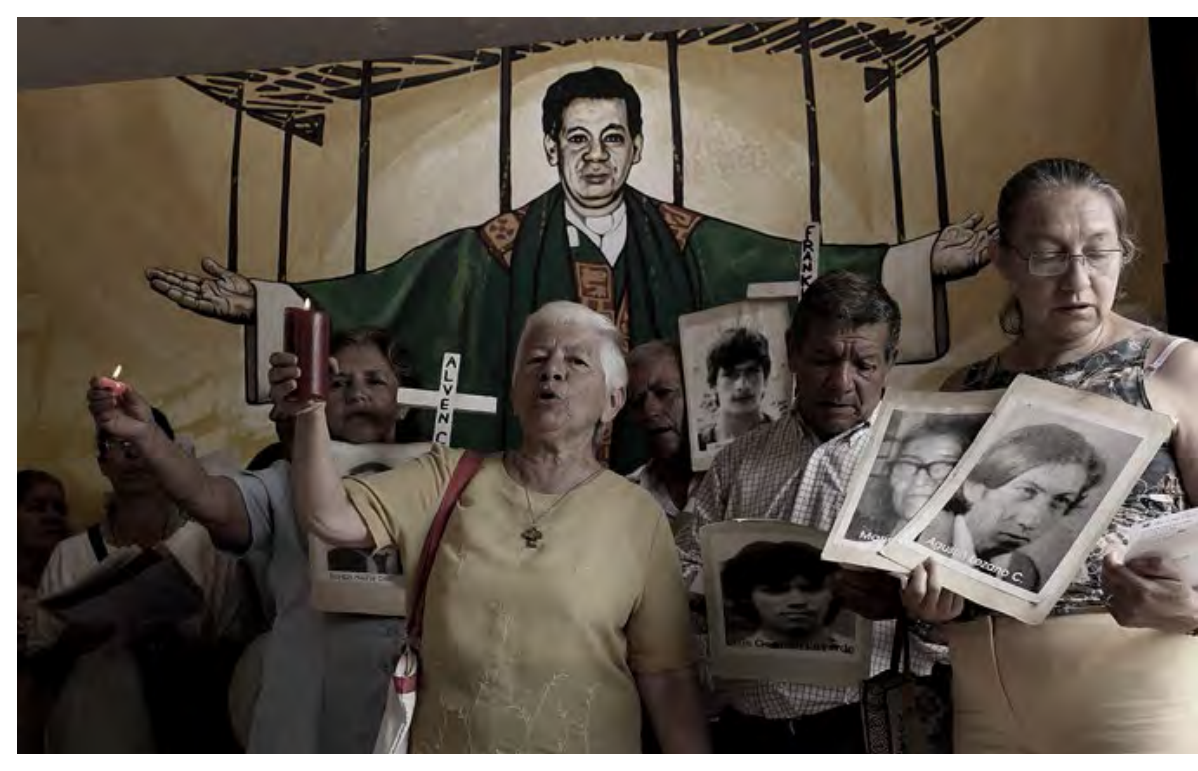

XII Peregrinación Nacional en memoria de las victimas, AFAVIT, Trujillo, Valle, 2012. Fotografía: Rodrigo Grajales 
manente, se convierten en dinámicas rituales oficiales, tal como sucede en la peregrinación anual en Trujillo.

En algunos momentos con la intención de denunciar el Estado y en otros de realizar apuestas pedagógicas dirigidas para la población en general, estas elaboraciones públicas implican otro nivel de participación, involucramiento y disposición con lo que se busca y con lo que se obtiene en términos rituales, ya que la práctica se convierte en un catalizador de la realidad política, toda vez que busca confrontaren una voz mancomunada, un padecimiento o un reclamo que se pretende hacer colectivo.

Para ello es importante comprender el ritual como mediación de acontecimientos políticos vinculados con la violencia, ubicando tres denominaciones que demarcan las intenciones propias en las cuales se va a producir esta práctica. Aclaro que esta clasificación obedece al análisis de las diferentes teorías sobre el ritual que se usaron en función de los casos investigados y desde el contexto de la violencia política colombiana.

La primera denominación refiere el ritual de forma explícita, en el que existe una apuesta social, pública y, ante todo, política; la segunda considear el ritual de manera mimética, el cual termina diluyéndose en las prácticas cotidianas, escondiéndose parcialmente en manifestaciones de lo ocurrido o miedo de lo que pueda suceder de nuevo, comportamientos o hábitos ritualizados que hablan o se expresan desde la elaboración estética de un objeto material o inmaterial para sí o para otros; y la tercera concibe el ritual de manera metafórica, en el que se pueden articular los dos primeros pero en su concreción se expresan por símbolos menos específicos: representaciones más generales, malestares o ideaciones que hablan de fenómenos diversos sin indicar elementos puntuales.

En el caso de la práctica estética de Hugo, se presenta un ritual de forma explícita, ya que la intención de su trabajo escrito, lo que pretende con este, es coincidente con la forma en la que racionaliza su proceso de elaboración; es decir, el ritual en su construcción, en ambos casos según él nada está por fuera de su búsqueda; por ejemplo, para la elaboración, cada elemento se debe encontrar dispuesto antes de crear, en donde todo es proyectado desde el día anterior: la adecuación del espacio para que nadie irrumpa, el café dispuesto a servirse solo al sentarse a trabajar, unos libros que deben estar a su lado y pueden o no ser usados en el proceso. El día anterior el escritor esboza ideas previas, pero solo hasta el momento de la creación define su utilidad, el valor insistente en la pérdida de temporalidad en el momento de la creación. En sus palabras: "se me hace eterna esa sensación de lo presente”. Finalmente, se impone el silencio como única garantía del éxito de su apuesta estética.

De igual manera, la pretensión con su trabajo es clara, tiene abiertamente un matiz político retratado en la necesidad de visualizar la Historia como un mediador con lo vivido; entiende que su labor busca presentar el pasado desde una visión más estética, pero igualmente con un componente social claro, en donde la mediación subjetiva apalabrada en una novela o en un cuento, expresa su historia de vida, la recuerda intencionalmente. Quiere con ello hacer un instrumento útil para hablar de la memoria del conflicto armado, sin que esto implique despersonalizar su recuerdo:

Siento que apelar a la memoria en este momento es necesario, siento que ahí hay una necesidad de trabajar fuerte la memoria y lo hago también como un elemento catártico (...) Yo no voy a darle una definición como si lo que yo hago fuese la luz, o la panacea, pero creo que es un aporte desde un ángulo, es un paso, algo que se acopla a este drama de la violencia que no sé cuándo vamos a superarlo. (Hugo, Entrevista 2)

El producto estético final media no solo como producto en sí, sino como recurso en el trámite personal que en toda la escena ritual es evocado, interpretado y representado de forma explícita.

Jhonathan, por su parte, construye su dispositivo estético desde una escena ritualizada de forma mimética, usa una figura ambigua en la cual se moviliza de la intención de no pretender verbalizar su experiencia con la violencia, en este caso por medio de la poesía, hacia la inserción de lo vivido entre líneas. Esa dicotomía entre resistencia y reconocimiento de su recuerdo vinculado con la violencia política, convierte su proceso de elaboración y producto final estético, en la narración de miles de víctimas que prefieren no hablar de su sufrimiento, pero que terminan haciéndolo de forma categórica, sin que esta sea su pretensión.

Eso que llamamos poesía nos toca las fibras, algo de nosotros se abre al mundo para volver a darle nombre a las cosas, para que miremos lo 
que los demás no ven. Es algo así como estar enamorado, pues solo el enamorado ve lo que los otros no ven. Ahora bien, todo eso tiene que ver mucho con mi pasado, aunque, en su gran mayoría, lo que intento decir está por debajo de eso que digo, subrepticiamente, oculto. Y tiene que ver mucho con mi pasado porque antes era demasiado tímido, ya que crecí en un ambiente donde las palabras no eran lo que decían, sino, más bien, lo que dejaban de decir. La gente del campo es así: se comunica sobre todo con los silencios. Además, la gente pobre del campo le teme a las palabras, pues, creo que más que nadie, ellos saben (sin saberlo desde teorías) que las palabras son pequeños incendios que uno guarda en laboca. (Jhonathan, Entrevista 4)

La lógica ambivalente entre lo que se niega pero se termina diciendo, es una figura mimética que de forma consciente o inconsciente permite tomar cierta distancia con el objeto final de la intención ritual, ya que este ubica una idea de distanciamiento que, como en el caso de Jhonathan, su pasado no constituye aparentemente su interés, pero después de cierto análisis metodológico, logrado por las entrevistas semi-estructuradas, es una evidencia indiscutible que su vínculo con lo vivido ancla su elaboración y su representación estética en su propia vida.

Si bien la mimesis ritual es una figura que en ocasiones desborda lo que el actor pretende realizar, esta enmascara de forma intencional el objetivo central de la escena, tal como sucede con Yulian y sus performances, donde el papel de la sangre se vuelve central, pues evidencia la crudeza de lo vivido. Lo que se deja entre líneas es un hecho manifiesto de su pasado que asume un carácter primario por la fuerza estética que este elemento implica; su asociación simbólica-real con la violencia conseguida por el imaginario del elemento, la fuerza del color y la densidad de los recursos expresivos empleados, implica una carga política clara, que interroga.

Así sucede con otros procesos menos planificados como el caso de Doña Nidia, una habitante de Trujillo, Valle, quien ha vivido un proceso de empoderamiento político por medio de AFAVIT (Asociación de Familiares Víctimas de Trujillo). En la organización ha encontrado no solo la posibilidad de identificar su dolor con el de otras víctimas sino también de apropiar una nueva subjetividad y participación política que no tenía antes de que desaparecieran sus seres queridos.
Doña Nidia, afectada por la desaparición de sus dos hijos, ha convertido su testimonio en todo un ritual de denuncia: su disposición física, el orden del discurso, las fotos de sus seres queridos. Los recortes de lo vivido desde ese entonces hasta el momento de la entrevista, indican una escena pulida, bien cuidada y ritualizada en el tiempo.

Sin embargo, adicional a este relato político de empoderamiento subjetivo y frustración con el Estado, aparece, sin dejarlo ver de forma explícito, casi como un comentario al margen: el hecho de mencionar que ella alberga dentro su casa unos objetos cuidadosamente guardados en espera de los cuerpos de sus hijos, con la intención de que estos simbólicamente cierren su proceso de duelo. Doña Nidia espera que estos objetos personales “puedan acompañarlos a la hora de enterrarlos. Allá los tengo". La posibilidad de un entierro que después de 30 años posiblemente no sucederá. Lo que sí sucede es el cuidado que ella tiene con los elementos simbólicos. Todo constituye una mímesis de su propia ritualidad, un deslizamiento del discurso politizado a la esperanza individual. Esta situación se pudo corroborar en la observación realizada al acompañarla por algunas horas en su residencia. Allí puso de relieve este elemento de conservación que se torna protagónico en el testimonio que antes no aparecía claro ni contundente cuando lo mencionaba.

\section{El ritual como metáfora, mediación política}

Es importante tener en cuenta que las condiciones de la violencia política en Colombia están estructuradas por múltiples capas relacionales, lo que lleva a pensar en un número amplio de actores involucrados, dispositivos de victimización, modos de operar y en general prácticas violentas asociadas al conflicto que toca las esferas más sensibles: lo político, lo cultural, lo social y lo económico.

Un ejemplo significativo de ello tiene que ver, precisamente, con los territorios y habitantes que han padecido la brutalidad de actos como masacres, desapariciones o desplazamientos que se visibilizan en la es- 


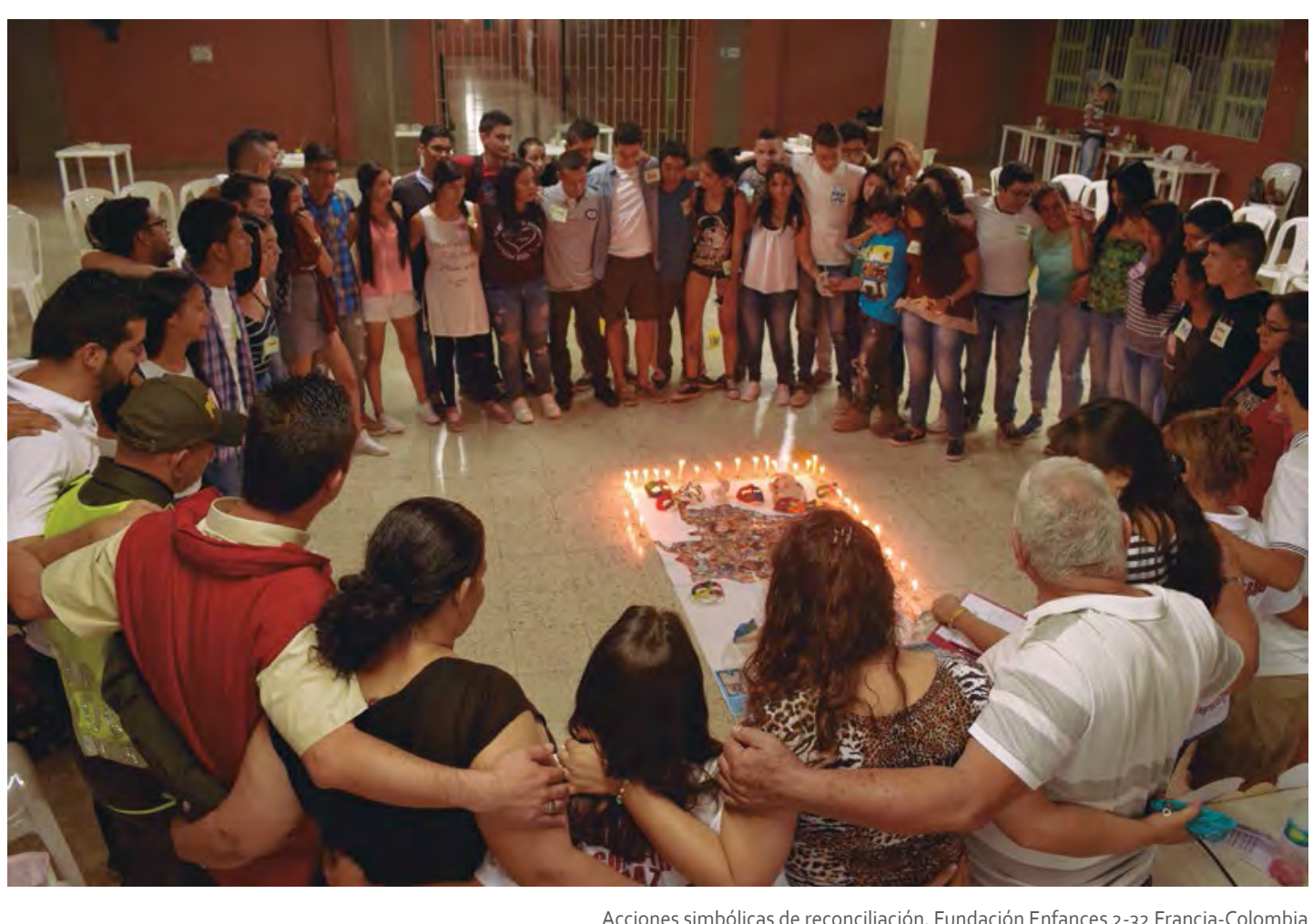

cena nacional e internacional a partir de la tragedia, es decir, el abandono histórico del Estado; lo que no solo los hace vulnerables ante los actores armados, sino también ante el propio Estado que los victimiza. La lista es larga: desnutrición, falta de servicios básicos, muertes por inanición, carencia de infraestructura vial, poca o casi nula inclusión educativa, deficiencia de sitios adecuados para la atención en salud, etc. Es el padecimiento económico y político que genera un Estado ausente, agravado por el desconocimiento del habitante urbano frente a la existencia de estos territorios y de las necesidades que padecen sus habitantes.

Se trata, en últimas, de una cultura naturalizada que no reconoce más allá de lo que se expresa en la esfera pública, ya que termina apelando a esa solidaridad filantrópica con las víctimas “legítimas”, puestas en la agenda pública a través de los medios a través de una narrativa esquemática: "solidaridad con los hermanos venezolanos", "con los niños de la Guajira” o con las víctimas de las frecuentes tragedias ocasionadas por la naturaleza. El colombiano sí posee una sensibilidad con el otro, pero infortunadamente su espíritu de indignación y apoyo aparece cuando se obtura la mirada desde la perspectiva exclusiva de los productores de discurso. Esta actitud invisibiliza problemas quizá más agudos y estructurales que se dan en todas las latitudes del país. Bojayá, Alto Naya, el Charco, el Aro, Remolino, Chivolo, la Gabarra, el Salado, Argelia, Mapiripán, Bahía Portete, Tarra, son algunos de los casos de pueblos que existen para el ciudadano gracias a su tragedia, paradoja sintomática de nuestra una sociedad. La historia de estos territorios parece que solo iniciara con su drama, una especie de ontología de la barbarie en donde la entidad pública se ve precisamente en actos donde se niega o maltrata su existencia vital. Como lo denomina Elsa Blair, estamos ante el uso de una "Economía del castigo" (2004), en donde se administra la vida, la muerte y la existencia del otro, controlando física y simbólicamente sus miedos y posibilidades de sobrevivir. Lo que no advierte la tesis de Blair es que parte del éxito de la inversión económica del control es garantizada por la falta de lugar (reconocimiento de su existencia) que le da el resto de la población colombiana a estas zonas, lo cual hace más sencillo el funcionamiento de lo que podríamos subrayar como la economía del dolor.
Estas poblaciones vulneradas cubren extremos diversos de la geografía colombiana; tienen en común el abandono previo del Estado, la disputa territorial de los actores armados y la presencia de condiciones insatisfechas precarias, lo que facilita el sometimiento ante prácticas de violencia extrema. El actor social es negado como ciudadano ya que hace parte de una nación que no le garantiza sus derechos básicos constitucionales. Se le somete como miembro de una comunidad desprotegida, puesta a merced de una economía del castigo impuesta por actores ilegales y desconocido por sus conciudadanos como sujeto activo de la sociedad colombiana; y más aún como víctima de un conflicto que ni siquiera se reconoce en el seno de la sociedad.

Empero, esta condición subjetiva empieza a cambiar gracias al empoderamiento político que asumen las víctimas como mecanismo de resistencia, con la esperanza de la reparación y la necesidad perentoria de la no repetición de lo padecido. Este ciudadano invisible para el resto de la 
sociedad se hace público y "real” en estas mediaciones políticas, ya que la negación de sus derechos no llegan con la tragedia, pues su desconocimiento ha venido dándose, de manera sistemática y de forma histórica, en un país proclive a olvidar y a repetir sus desafueros.

Los procesos de ritualidad, que permiten dicha apropiación y empoderamiento en pos de la recuperación del tejido social, se materializan de manera particular con las mediaciones estéticas metafóricas en comunidades que han podido resistir de forma colectiva, como un intento de asumir una denuncia política, de elaborar un duelo o un corte ante la pérdida o el padecimiento recibido, al mismo tiempo que se transmiten las tradiciones, los valores o las condiciones histórico- culturales que las identifican como territorio.

Este es el ejemplo de lo sucedido en la desaparición de 60 personas y la masacre de casi un centenar de pobladores, en el Alto Naya en el Cauca en el año 2001. Hablamos aquí de un territorio de fuerte influencia indígena. La conocida "masacre del Naya” permitió, después de mucho sufrimiento, en especial por parte de las mujeres, poco a poco reconstruir su base social y re-significar su noción de identidad. En palabras de una habitante de la zona:

Nosotras casi la mayoría pues no sabía si era india, si era gringa o si era campesina o quéera. Al organizarme me di cuenta que yo era indígena. Claro yo pienso que sí, porque nosotras las mujeres tenemos más la capacidad de asimilar, como de superar los problemas, porque ya sabemos que nosotras somos capaces de tener un hijo, ahora cómo no vamos a ser capaces de superar problemas. (Verdad Abierta, 2013)

No solo la organización y el lugar de la elaboración de diversos rituales con una intención metafórica que reclama Justicia y Reparación permite empoderar nociones como la étnica o la campesina como en el caso del Naya, sino a su vez reivindicaciones como la de género, por medio de las cuales también se exige el rol social que le corresponde en este caso a la mujer, más allá de simplificarlo todo en la noción de víctima. En palabras de la habitante indígena, se trata del poder de la palabra y en relación con lo que venimos trabajando, se trata del poder de la metáfora como posibilitadora. Con su empleo se diversifican las demandas, las representaciones y las múltiples formas de hacer del ritual una apuesta estética que no se limita a un mero discurso de enunciación y representación.

\section{Del territorio al reasentamiento}

El ritual, como medio de oposición y/o resistencia, ante un colectivo y ante un sistema ordenado de normas y roles comunitarios, se presenta de múltiples formas. Tiene particular significado en las comunidades reasentadas, muchas de las cuales se resisten a perder valores tradicionales propios y demandan, por medio de actos colectivos, el reconocimiento y la posibilidad de expresar aquello que les pertenece por encima del lugar al que llegan para tejer sentido de comunidad.

Por un lado, procuran la visibilización de su territorio y cultura más allá del espacio que habitan y, por el otro, asumen la denuncia del dolor y el drama que continúa en la impunidad. Al respecto, en una entrevista realizada a un miembro de una comunidad reasentada, proveniente del Tolima, habitante de la urbanización Salamanca -proyecto del Estado con víctimas por diferentes causas provenientes de distintos lugares del país en las periferias de la ciudad de Pereira-, expresó lo siguiente: "El gobierno promete, pero no cumple, sin embargo nosotros no dejamos y no dejaremos de movernos". Buscar visibilizar su tragedia es mantener vivo en cada acto la responsabilidad inconclusa del Estado. No dejar de moverse es persistir en actos de denuncia que no dejen en el olvido o en la superviviencia de la vida cotidiana aquello que no ha sido reparado. Este tipo de comentarios es bastante frecuente en el barrio y en las movilizaciones en la oficina de la unidad de reparación de víctimas organizadas desde y con algunos de los líderes de este sector. Sobre todo en los días en donde más confluyen personas a reclamar subsidios. Esta confluencia se torna en una práctica que apela a la identificación de otras víctimas, así como a la solidaridad de los ciudadanos con sus problemáticas.

De otra parte, bailar y llorar en medio de danzas nocturnas al ritmo de tambores en medio de grandes urbes, es un ejemplo de conservación del 
patrimonio cultural de algunas comunidades reasentadas provenientes del Chocó. Ellas cuidan una tradición que los define, al tiempo que denuncian, exorcizan y ante todo expresan la oposición al gobierno. Así, vivifican el ritual que busca alterar un sistema de ordenamiento social preestablecido. De ahí la importancia de tomarse la calle, de hacer desaparecer la autoridad estatal al calor de la escena cotidiana en la que se impone el bailarín y se practica el alabao, al grito desproporcionado que no legitima una figura oficial alguna; al contrario, todo se democratiza en la dinámica de los partícipes de los rituales. Siguiendo a Segalen:

El rito o ritual es un conjunto de actos formalizados, expresivos, portadores de una dimensión simbólica. El rito se caracteriza por una configuración espacio-temporal específica, por el recurso a una serie de objetos, por unos sistemas de comportamiento y de lenguaje específicos, y por unos signos emblemáticos, cuyo sentido codificado constituye uno de los bienes comunes de un grupo. (Segalen, 2005, p. 30)

Estas funciones del ritual se hacen más complejas cuando se abordan otros elementos simbólicos de relevancia en toda la estructura y en su efectividad. Esto sucede con el rol y la responsabilidad de quienes asumen prácticas que denuncian o recuerdan lo acaecido en sus comunidades. La ineficacia del Estado en la protección de estas comunidades, implica actores denunciantes de su tragedia y, a su vez, testimoniantes del episodio perpetrado. Se superpone aquí una doble condición de víctima y testigo "primario" del crimen, que en rituales de reconocimiento de su identidad metafóricamente también hablan de sus experiencias vividas a manera de exposición y denuncia.

En una de las visitas de campo que realizamos, evidenciamos el hecho de ver cómo la complicidad de la noche y su silencio, constituyen la preliminalidad perfecta para iniciar el ritual. Este arranca en el momento en que se tocan, de forma violenta y repentina, las puertas de los participantes. Es, desde luego, una irrupción abrupta, una serie de simulación del momento en el que la violencia extrema tocó las puertas de sus casas en medio de la noche, en esa ocasión para asesinarlos, desaparecerlos o intimidarlos. El escenario, por fortuna, es distinto, pues la invitación es a salir bailando, cantando y coreando colectivamente para, de esta forma, re-escribir a su manera el pasado, al tiempo que inauguran una práctica ritual cada vez más masiva en donde la metáfora transita entre lo vivido como víctimas y el rescate de su identidad como pueblo afro.

Finalmente, las prácticas colectivas que se dan en espacios públicos de forma natural como marchar desde su condición de sujetos de derechos que se toman la calle ante una victimización permanente, implica exponerse ante los ojos de los demás, visibilizar una causa, un rostro, un retrato que se niega a quedar en el olvido. Un ritual que tiene su preparación desde la mañana: la ropa cómoda, los zapatos, preferiblemente un objeto que se pueda portar en el trayecto de la movilización, buscar ampliar la imagen, pegarla en un recuadro y evocar un poco el recuerdo nostálgico de su ser querido antes de llenarse de valor para caminar trayectos extensos. Vendrá luego el grito, la pronunciación del nombre de quien ya no está, enunciando en el asfalto al ausente, mientras se demanda justicia por lo ocurrido.

Se grita, se llama, pero también se busca. En palabras de una de las víctimas con las que se se hizo labor testimonial: "En ocasiones en la multitud busco al ausente. Me parece que en cualquier momento va a aparecer con la ropa sucia, en medio de la nada". Se llora, se "camina" la tristeza, esperando que el despuntar del día traiga consigo el cansancio y la satisfacción de que el ausente aún está presente y de que ahora, más que nunca, no está muerto, que salió a participar de la marcha con todos. De esta forma, los familiares se vuelven personas públicas y, consecuentemente, su vida privada salta a la calle. Aquí se valida un método de catarsis, pero también de resistencia al olvido de los desaparecidos. Aquí se nutre un mecanismo que puede garantizar que los ojos enfocados en un grupo vulnerado frenen la posible repetición de los hechos o, al contrario, la agudicen por aquellos que quieren mantener la desaparición en la impunidad. 


\section{Referencias bibliográficas}

Abascal, I. H. (2015). “Transferencias: de lo cotidiano al arte, del arte a lo cotidiano.” En Artes La Revista, 4 (8), 65 - 74. https://revistas.udea.edu.co/ index.php/artesudea/article/view/22980

Augé, M. (1998). La guerra de los sueños, ejercicios de etno-ficción. Ed. Gedisa.

Augé, M. (1992). Los no lugares. Espacios del anonimato. Una antropología de la sobremodernidad. Ed. Gedisa.

Barthes, R. (2004). Crítica y Verdad. Ed. Siglo XXI.

Carvajal, J. (2018). “El relato de guerra: Cómo el arte transmite la memoria del conflicto en Colombia”. En Amerika [En ligne], 18 | 2018, mis en ligne le 28 juin. https://journals.openedition.org/amerika/10198

Douglas, M. (1973), (1966). Pureza y peligro: un análisis de los conceptos de contaminación y tabú. Ed. Siglo XXI.

Durand, G. (1968). La imaginación simbólica. Ed. Amorrortu.

Durkheim, E. (1993). Las formas elementales de la vida religiosa. Ed. Alianza.

Durkheim, E. (2001). Las reglas del método sociológico. Fondo de Cultura Económica.

Frazer, J. (1944). La rama dorada: magia y religión. Fondo de Cultura Económica.

Gennep Van, A. (1986). Los ritos de paso. Taurus.

Goffman, E. (2004). La presentación de la persona en la vida cotidiana. Ed. Amorrortu.

Girard, R. (1975). La violencia y lo sagrado. Ediciones de la Biblioteca.

Gluckman, M.; Douglas, M.; Horton, R. (2003). Ciencia y brujería. Anagrama.

Hall, S. y G. Paul. (1996). Cuestiones de identidad cultural. Ed. Amorrortu.

Jodelet, D. (1986). “La representación social: fenómenos, concepto y teoría”, En Moscovici, S. Psicología social (tomo II). Ed. Paidós.

Levi-Strauss, C. (1984). Pensamiento salvaje. Fondo de Cultura Económica.

Mauss, M. (1971). “Ensayo sobre los dones, razón y forma de cambio en las sociedades primitivas”. En Sociología y Antropología. Ed. Tercer Mundo.

Mauss, M. (1970). Obras. Ed. Barral.
Sáez, F. (2000). El proceso ritual de Víctor Turner. Antropología cognitiva y simbólica”. Ed. UNED Centro Asociado de Melilla.

Segalen, M. (2005). Ritos y rituales contemporáneos. Ed. Alianza.

Turner, V. (1988). El proceso ritual: Estructura y antiestructura. Ed. Taurus.

Turner, V. (1997). La selva de los símbolos: aspectos del ritual Ndembu. Ed. Siglo XXI.

Weber, M. (1984). La acción social: ensayos metodológicos. Ed. Península. Barcelona.

Verdad Abierta. (2013). Testimonio del informe "La verdad de las mujeres”, en Verdadabierta.com. https://verdadabierta.com/mujeres-victimas-de-la-masacre-del-naya/ 
Mediaciones estéticas expresividades de la memoría 


\section{A manera de epílogo}

A lo largo de esta reflexión nos hemos ocupado de dar cuenta de tres perspectivas que involucran formas concretas de mediación estética. Las tres se configuran a partir de acercamientos que comprometen el despliegue de una serie de apuestas expresivas, cuyo sentido horada acontecimientos y experiencias ligadas con las diferentes formas de violencia política, presentes en la sociedad colombiana contemporánea.

En el contexto de estas miradas, el sentido de lo estético hace referencia a una dimensión ampliada de lo sensible que, al no estar circunscrita a una conceptualización sobre los aspectos formales del arte, permitió reconocer y valorar cómo operan los dispositivos de mediación y exteriorización expresiva, cuando se articulan a procesos de construcción de sentido, ligados en su mayoría con el drama del conflicto armado interno $\mathrm{o}$ a las tensiones y altibajos provocados por los problemáticos procesos de transición política, como desenlace de dos momentos de activación que han tenido lugar en los últimos 20 años. El primero de estos momentos hace referencia a la implementación de la ley 795 de 2005, mejor conocida como la Ley de víctimas y la creación de lo que anteriormente conocimos como la Comisión Nacional de Reparación y Reconciliación (Posteriormente Centro Nacional de Memoria Histórica). El segundo momento hace referencia al marco del acuerdo de paz firmado con la guerrilla de las Farc en 2016 y la implementación del Sistema Integral de Verdad, Justicia, Reparación y No repetición, conformado por la Jurisdicción Especial para la paz (JEP), la Unidad de Búsqueda de Personas Desaparecidas (UBPD) y la Comisión para el Esclarecimiento de la Verdad, la Convivencia y la 
En las experiencias abordadas en nuestra reflexión se fundamenta la eficacia de los dispositivos expresivos en los procesos de agenciamiento y resignficación de la memoria individual y colectiva, desde miradas que comprometen prácticas artísticas y prácticas sociales, en contextos donde la experiencia directa con situaciones o acontecimientos violentos ha contribuido a fracturar aquellos vínculos afectivos, tan necesarios para la cohesión de grupos sociales en sus comunidades.

A manera de epílogo, en este apartado intentaremos dar cuenta de las posibilidades abiertas por la mirada de los investigadores, no sin antes advertir que ninguna de estas lecturas agota la discusión o el horizonte de análisis que compromete la temática. Se trata, más bien, de señalar unos anclajes provisionales, porosos e inestables, que además de insinuar un trayecto metodológico, plural y polifónico, se interesa por tematizar y referenciar el modo como opera la noción de mediación en tres ámbitos de la experiencia sensible: las prácticas artísticas, las prácticas estéticas y las prácticas expresivas.

\section{Mediaciones estéticas en el contexto de las prácticas artísticas}

Como hemos mencionado, esta reflexión toma como base una comprensión ampliada de la estética que, si bien no se limita a la tematización de las expresiones artísticas, tampoco excluye su consideración dentro del campo de comprensión de lo sensible, dado que no se trataba de construir una particular visión de la estética para adscribir o seleccionar, en función de ella, unas determinadas microexperiencias culturales o sociales. Lo que se buscaba, más bien, era usar ese horizonte ampliado para intentar comprender las prácticas escogidas, en los escenarios y circunstancias donde cada una emergía.

De esta manera, se fue constituyendo un corpus de formas de mediación, cuyo análisis nos permitió afianzar tres configuraciones de los procesos creativos en la sociedad contemporánea y, de manera particular, aquella comprometida con diferentes acontecimientos vinculados con la violencia política en Colombia. En coherencia con esto esbozamos un trayecto investigativo en el que, de manera recurrente, nos preocupamos por oscilar entre tres formas de poner en práctica, o en obra, la experiencia sensible y situarla en el escenario de unos acontecimientos que las particularizan. Tres maneras, en fin, de considerar el lugar que ocupan los registros de enunciabilidad y los nuevos dispositivos de visibilidad en un paisaje de acontecimientos, en el que es posible reconocer, apoyados en Rancière (2014), un nuevo "reparto de lo sensible", en el cual la experiencia del arte afianza una forma de relación totalmente distinta a la que dominaba la época de la representación mimética. De allí la posibilidad de operar un giro en la mirada, consecuente con el sentido que entraña ese nuevo "régimen estético del arte" en el que su identificación deja de estar orientada por las formas de hacer, para poner el énfasis en el modo de ser sensible que compromete el sentido con el que acontecen la prácticas expresivas (p. 35): "el régimen estético de las artes es aquel que identifica propiamente el arte en singular y desliga ese arte de toda regla específica, de toda jerarquía de los temas, de los géneros y de las artes." (p. 36).

Desde el horizonte abierto por esta posibilidad de existencia del arte y la estética, fue viable pensar en dos vías concomitantes para la configuración del corpus, las cuales nos permitieron, por un lado, visibilizar proyectos, obras, iniciativas y acciones en las que la noción de mediación se configuraba como clave para horadar algunos de los traumas irresueltos de la violencia política y, por otro lado, evidenciar el modo como tales prácticas iban proponiendo una re- configuración o adecuación de la relación entre sujeto y acontecimiento, de acuerdo con las situaciones y contextos comprometidos en cada proyecto.

Es así como en la primera de las perspectivas abordadas en este trabajo se hace referencia a prácticas artísticas que han acometido formas de interacción con comunidades, grupos de sobrevivientes y familiares de víctimas, como una manera de acompañar sus demandas de conmemoración o de proponer registros que hacen visibles rasgos fundamentales de sus vivencias. Como casos de estudio, en esta primera aproximación nos ocupamos de algunos de los proyectos creativos de los artistas Juan Manuel Echavarría, Erika Diettes y el colectivo "Magdalenas por el Cauca”. 
Más que enfatizar sobre las consideraciones formales de los proyectos creativos elegidos, el sentido de esta reflexión tomó como punto de partida el reconocimiento de las prácticas artísticas como parte fundamental de los procesos de transmisión cultural, esto es, la forma como los grupos y colectivos asignan sentido a los acontecimientos, nombran los sucesos, definen las relaciones en las que se encuentran inmersos y negocian los límites de interpretación de los hechos que conforman sus vivencias. Por esta razón, en esta primera perspectiva, nos ocupamos de considerar las mediaciones que estas prácticas artísticas configuran en relación con la experiencia sobre la violencia política.

En este contexto, la noción de mediación guarda un vínculo importante con lo planteado por Regis Debray (1997), en relación con la posibilidad de comprender las prácticas artísticas como un modo de hacer o de obrar contextualizado, que involucra tres dimensiones, a saber: lo material, lo diacrónico y lo político. En relación con la dimensión material, las prácticas artísticas transmiten sentido, en la medida en que no solo comportan la emisión de un mensaje que será aceptado o rechazado por su receptor, sino que implican el trabajo creativo sobre los recursos materiales que hacen parte del mundo, sean ellos objetos, imágenes, sonidos, así como el dominio de la técnica, como forma de obrar e intervenir la materia. En relación con la dimensión diacrónica, las prácticas artísticas proponen formas de expresividad que, por más efímeras que sean, en su manifestación apuntan a elaborar significados, formas de pensar sobre el tiempo y el espacio, las cuales provocan interacciones entre temporalidades diversas y confluyen de forma intermitente. Al respecto advierte Debray:

Transmitimos para que lo que vivimos, creemos y pensamos no muera con nosotros (más que conmigo). Para hacerlo, nos está permitido, según las épocas, recurrir a los medios de la poesía oral -con sus ritmos y ritornelos propicios a la memorización-, deldibujo o el escrito, el impreso, la cinta de audio o Internet -todo junto o separadamente-, de acuerdo con las audiencias a las que se apunta o el desarrollo técnico, pero el contenido del mensaje se guía por las necesidades de su expedición, como el órgano por la función. (Debray: 1997, p. 18)

De este modo, las prácticas artísticas constituyen, sobre todo, duraciones y formas de interacción entre temporalidades distintas, que compro- meten, más allá del sentido inmediato que podamos tejer, una consideración sobre los "vínculos entre los vivos y los muertos" (Debray, 1997, p. 17). Por último, la dimensión política apunta al hecho de que la inscripción de estas prácticas necesariamente implica un escenario de conflicto. Las prácticas artísticas proponen la apertura del sentido que los grupos humanos le asignan a los acontecimientos y las experiencias, en lugar de una mirada reduccionista o explicativa. Por lo tanto, su materialización arrastra siempre una necesidad de negociación, de puesta en común (en comunidad) o de participación ampliada en el ámbito de lo público.

A la luz de estos planteamientos de Debray, las prácticas artísticas a las que hemos hecho referencia proyectan modos de interacción con grupos de sobrevivientes y asociaciones de familiares de víctimas, al tiempo que proponen formas de expresión creativa, disposiciones particulares de materialidades, recursos técnicos y simbólicos cuyo efecto da lugar a construcciones de sentido o pone en obra inscripciones en las que, de manera explícita, aparecen tematizados diferentes acontecimientos ligados al fenómeno de la violencia política en Colombia. Desde su configuración sensible, estas prácticas aportan una instancia expresiva que permite hilvanar un correlato de gran valor para comprender la forma como la experiencia del arte concita e instituye una experiencia de carácter colectivo, anclada a contextos particulares de la realidad.

Un segundo aspecto para considerar, en relación con las formas de mediación artística, tiene que ver con la interacción entre las prácticas y sus contextos de recepción o inscripción pública. Es decir, la interacción entre la singularidad de los hechos que originan las imágenes, los objetos, testimonios e indicios reunidos en cada práctica artística y la efectividad de su transferencia. Sobre estos aspectos, advierte Bal:

La mediación es una forma calificada de lo que desde hace mucho conocemos como transferencia entre hacedor (o, en términos semióticos, emisor) y espectador (receptor). A diferencia de lo formulado por los puntos de vista tradicionales, esta mediación no es una simple entrega unidireccional. Por añadidura, entre hacedor y espectador sucede algo que no puede ser del solo orden de la comprensión. Para que el arte sea políticamente eficaz -para que tenga agencia en la esfera política- es preciso "traducir" de algún modo su contexto de emergencia a un con- 
texto desde cuyo interior el receptor pueda ser sensible a la urgencia de la obra. Esta mediación se lleva a cabo mediante la actividad de "meta-

forizar”. (2014, p. 35)

Desde este horizonte, las prácticas artísticas que conforman el objeto de estudio de nuestra investigación proponen marcos expresivos que confrontan al espectador con su propio contexto colectivo, a través de la acción de hacer visibles una serie de indicios, imágenes y testimonios que aluden a algunas de las implicaciones de la violencia como condición estructural de la sociedad colombiana. Sin embargo, tal confrontación se hace tolerable en la medida en que se propone a través de recursos metafóricos, simbólicos o performativos. Esta condición expresiva, en lugar de restar veracidad al contenido de estas prácticas, le devuelve el peso y la densidad necesarias para consolidar apuestas de resignificación y conmemoración.

Lo anterior nos permite, también, establecer un marco reflexivo para repensar las relaciones entre las prácticas artísticas y sus formas de inscripción política, lo cual, desde la perspectiva de autores como Jaques Rancière, implica problematizar, sobre todo, la "eficacia de las prácticas artísticas” (2010). Este planteamiento se relaciona con tres conformaciones tradicionales que prevalecen históricamente desde inicios de la modernidad, como formas de comprensión de la relación entre arte y política. En primer lugar, aquella que afirma que "el arte es político porque muestra los estigmas de dominación” (Rancière, 2010, p. 54). Es decir, la politicidad del arte es valorada en cuanto las prácticas artísticas están en capacidad de representar los dilemas morales y conflictos políticos del colectivo social, subordinando su capacidad expresiva a la denuncia de las formas de poder dominante o a modelar lo que se consideraría correcto o reprochable. Lo problemático de este modelo según Rancière, no concierne entonces a la validez moral o política del mensaje transmitido por el dispositivo representativo. Concierne a ese dispositivo mismo. Su fisura deja aparecer que la eficacia del arte no consiste en transmitir mensajes, ofrecer modelos o contramodelos de comportamiento o enseñar a descifrar las representaciones. Consiste antes que nada en disposiciones de los cuerpos, en recortes de espacios y de tiempos singulares que definen maneras de estar juntos o separados, frente a o en medio de, adentro o afuera, próximos o distantes. (2010, p. 57)

Esta fisura da lugar a otro modo de "eficacia del arte" desde el cual la politicidad de las prácticas artísticas se expresa en su capacidad de salir "de los lugares que le son propios para transformarse en práctica social" (Rancière, 2010, p. 54). En este caso, ya no se trataría tanto de que las prácticas artísticas representen los conflictos morales y políticos, sino de que su propia construcción es inseparable de los modos de vida colectiva. Es decir, en este caso, las prácticas artísticas afirman una relación constitutiva con las dinámicas sociales: "el arte sin representación, el arte que no separa la escena de la performance artística y la de la vida colectiva” (Rancière, 2010, p. 57).

Por último, la contraposición entre las dos conformaciones anteriores da lugar a una tercera forma de eficacia de las prácticas artísticas, denominada por el autor como "eficacia estética” (2010, p. 58). El aspecto central de esta perspectiva es "el disenso". Al respecto, advierte Rancière:

Lo que yo entiendo por disenso no es el conflicto de las ideas o de los sentimientos. Es el conflicto de diversos regímenes de sensorialidad. Es en ello que el arte, en el régimen de la separación estética, se encuentra tocando a la política. Pues el disenso está en el corazón de la política. (2010, p. 61)

Según este planteamiento la eficacia de las prácticas artísticas, no se corresponde con una naturaleza mimética en la que se reflejan y moldean los conflictos morales y los comportamientos colectivos, ni con aquella en la que se funden las conformaciones de las prácticas artísticas y la vida colectiva, sino que opera a través de una aparente desconexión. Es decir, de la posibilidad expresiva de una conformación tanto material como discursiva, que reclama una función propia, a veces en tensión, a veces articulada con intereses, hechos y acontecimientos sociales, pero que no coincide de forma plena con una intencionalidad o con una expectativa determinada, por más loable o necesaria que se considere por parte de los sectores que se sienten convocados o confrontados frente a su manifestación.

Ahora bien, más que intentar ubicar las prácticas artísticas analizadas en el marco de alguno de estos modos de eficacia artística, lo anterior per- 
mite reconocer la confluencia de algunos de los aspectos de estos modelos y su compleja interacción en el marco de un contexto político polarizado, como resulta ser el caso colombiano. Por otro lado, propicia el reconocer que las relaciones entre prácticas artísticas, estética y política son disímiles, pero inevitables. En consonancia con esto, resulta importante considerar que en las prácticas artísticas analizadas se configuran, además de una aproximación a las dinámicas de la violencia política, una serie de procesos de interacción con sobrevivientes y familiares de víctimas que dieron lugar a trabajos en campo de largo aliento, estancias prolongadas por parte de los artistas en zonas geográficas en las que tuvieron lugar acontecimientos relacionados con las dinámicas del conflicto armado interno, como parte del proceso de concreción de sus apuestas creativas.

Como producto de esta interacción cobraron relevancia, entre otros aspectos, el poder evocador de las ruinas, la carga simbólica de los objetos personales y las prendas de vestir como sustratos expresivos que devuelven densidad al recuerdo de las personas desaparecidas; así como los rostros, las gestualidades del dolor y el componente de lo testimonial como formas de particularizar los relatos, de posicionarlos en personas concretas que vivieron de forma directa los efectos de la violencia. Esas mismas personas que posteriormente se reúnen y se disponen en un marco expresivo que permite, hasta cierto punto, el acendramiento de una experiencia de conmemoración, inscrita en nuevas reflexiones y saberes que potencian las apuestas de memoria colectiva.

\section{La co-laboración como estrategia de mediación estética}

En la misma perspectiva trazada por Rancière (2011) en torno a la singularidad de una época en la que tanto las prácticas estéticas como las relaciones que estas concitan se expanden en su sentido y efectos, desligándose del interés por adecuar formas con modos de hacer para afianzar experiencias ampliadas de lo sensible, en la segunda parte de esta investigación ponemos en contexto una serie de formas de mediación estética,

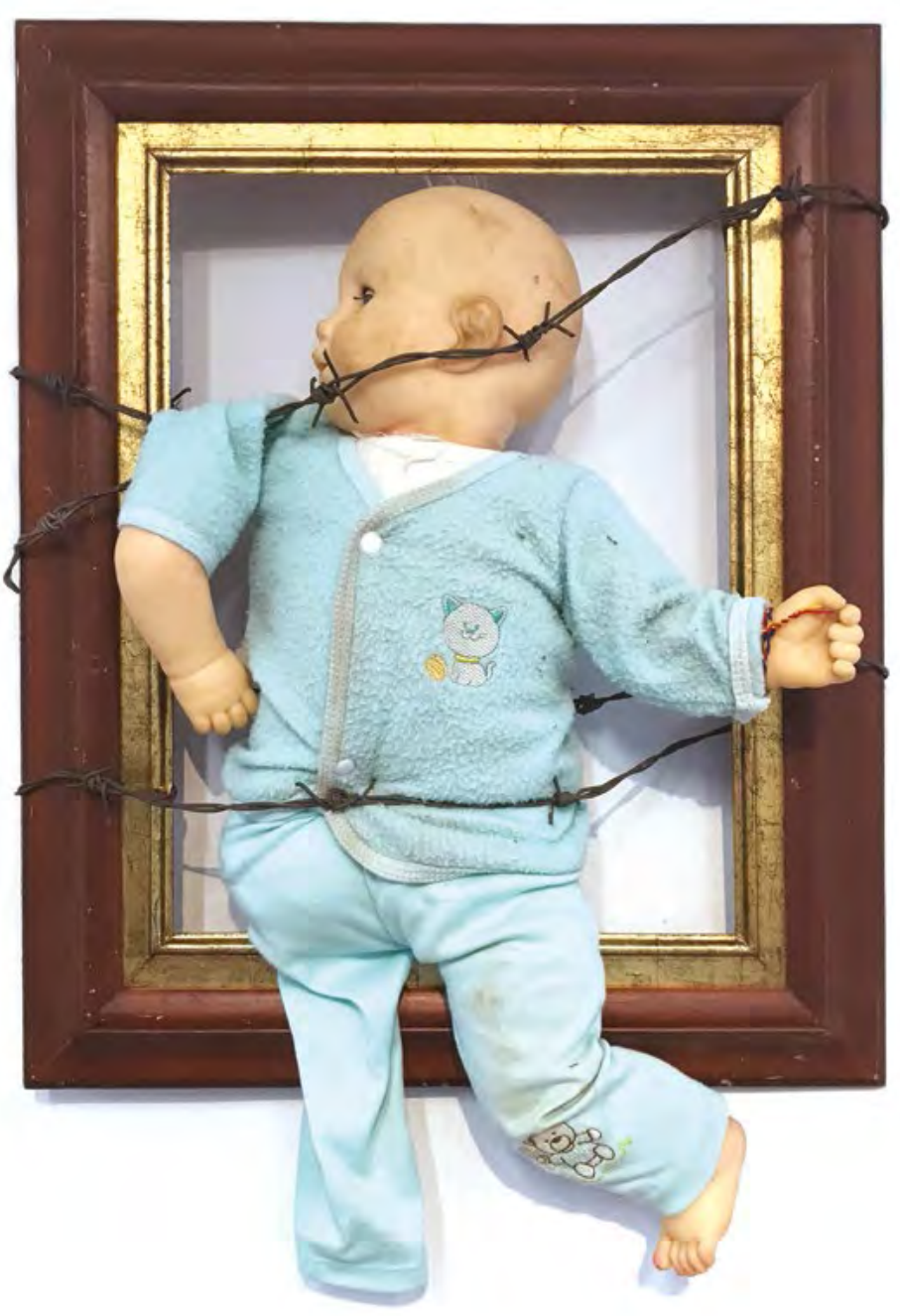


de carácter colaborativo y relacional, en las que el énfasis no recae, propiamente, en la calidad de las producciones, sino en el tipo de relaciones afectivas que los colectivos tejen, como parte del agenciamiento y resignificación de sus memorias individuales y colectivas.

Más que un corpus preciso, lo que se intentó en este acercamiento fue sumar a la mirada precedente dos nuevos ámbitos de mediación en los que las prácticas estéticas y artísticas despliegan su potencia cohesionadora y, por lo tanto, religante, al ser legitimadas por unas colectividades o una institucionalidad que reconocen en ellas un recurso sensible, clave para movilizar experiencias o detonar acontecimientos que comprometen la recreación o la recuperación de la memoria individual y colectiva. El tránsito por este sentido de la mediación estética nos permitió penetrar el complejo entramado de intercambios expresivos, simbólicos y afectivos que se tejen en los proyectos colaborativos y su incidencia en la reconfiguración de nociones como las de autoría y obra.

El foco puesto en el proyecto La guerra que no hemos visto, realizado por el artista Juan Manuel Echavarría con participación de actores vinculados y desvinculados del conflicto armado, y las acciones desplegadas por el colectivo "Magdalenas por el Cauca”, integrado por los artistas Gabriel Posada y Yorlady Ruiz en las que involucran de manera directa las asociaciones de víctimas de la Masacre de Trujillo (Valle del Cauca) y miembros de la comunidad ubicada en la zona ribereña del río Cauca, en el norte del Valle del Cauca y Risaralda, nos permitió reconocer estrategias de activación de la experiencia vivida y la recordación, ampliadas en su alcance por recursos configuradores, relatos testimoniales, registros visuales, acciones performativas y materialidades diversas. La función de las prácticas estético-artísticas en estos escenarios es, como lo advierte Rancière (2011, p. 31), la de generar espacios y relaciones que permitan configurar "material y simbólicamente" el territorio de aquello que no es común y que, en los casos analizados, nos vincula como miembros de una comunidad de sobrevivientes, concernidos por el drama, el desplazamiento, el despojo, la pérdida, el abandono del Estado, la acción o la omisión de los hechos.

De manera correlativa, este trayecto también nos permitió identificar una serie de procesos de apropiación de los dispositivos expresivos por parte de organizaciones de la sociedad civil que reconocen en las mediaciones expresivas, pedagogías sensibles y disruptivas, necesarias para activar, tramitar e inclusive transmitir los registros fragmentarios que ponen en relación esa doble condición de la memoria distendida en el tiempo: la de un pasado cargado de vivencias y recuerdos y la de un presente en transición, marcado por la incertidumbre. Los registros derivados de estas experiencias operan, sin duda, una suerte de desvío en la narrativa oficial de la memoria de los actores del conflicto, procurando la emergencia de nuevos vectores de significado, cuya naturaleza sensible y creativa les permite circular y visibilizarse de manera abierta en la esfera de lo público, como expresión del posicionamiento social de sus protagonistas o como posibilidad proyectada en el tiempo.

En coherencia con la noción de lo “acontecimental” planteada por Baudio (2003), esta comprensión de la mediación estética abordó una serie de prácticas en las que se apela a formas de enunciación y exhibición de la experiencia individual y colectiva, a partir de una serie de recursos expresivos en los que el acento no está puesto en la condición formal de las creaciones, sino en la posibilidad de rescatar el carácter mediador y, por ende, político, modulador y religante que animan estos dispositivos en el contexto social. En la densidad de estas mediaciones, prácticas como pintar, dibujar, modelar, tejer, coser, conversar, escribir, cantar, cultivar, cocinar o intervenir el cuerpo, se convierten dispositivos efectivos para detonar el acontecer del recuerdo, clausurado por los regímenes de verdad legitimados por la institucionalidad.

Al margen de la pretensión de cartografiar un número exhaustivo de experiencias de mediación estética, nos interesamos por señalar unos referentes emblemáticos y puntuales que, además de obligarnos a reflexionar en el alcance de estas interacciones en el paisaje fragmentario e inestable que ha configurado la violencia política y la implementación de los Acuerdos de Paz firmados en 2016, nos sirvieran de provocación para trazar nuevas rutas de indagación en las que se comprometan las mediaciones expresivas y el comportamiento emotivo. Tampoco se trataba de identificar prácticas de mediación que apelaran a un consenso social o político sobre la manera como se debe configurar o tramitar la memoria indi- 
vidual o colectiva. Por el contrario, a lo largo de este proceso insistimos en la urgencia de reconocer en estas apuestas una pedagogía para animar un disenso expresivo que, al mismo tiempo, se reconozca como postura ética, una forma de acción política y una práctica social, propicia para reterritorializar el devenir de un tiempo en el que, antes que clausurar el relato de la memoria, lo mantenga abierto, lo declare inconcluso.

\section{La noción de dispositivo activador de las mediaciones estéticas}

La noción de dispositivo representa para el pensamiento contemporáneo la posibilidad de reunir en un concepto, complejo y potente, diversos aspectos que comparten una misma naturaleza: la de actuar o incidir en prácticas humanas insertas en relaciones de poder. A través de su carácter funcional y al mismo tiempo expresivo, el dispositivo puede inscribir o soportar trazas culturales, estéticas y políticas que se despliegan en conformaciones institucionales, jurídicas, expresivas o discursivas. Es en este sentido que para Agamben (2014):

A. El dispositivo es un conjunto heterogéneo que incluye virtualmente cualquier cosa, tanto lo lingüístico como lo no lingüístico: discursos, instituciones, edificios, leyes, medidas de policía, proposiciones filosóficas, etc. En sí mismo el dispositivo es la red que se establece entre estos elementos. B. El dispositivo siempre tiene una función estratégica concreta y siempre se inscribe en una relación de poder. C. Como tal, resulta del cruce entre relaciones de poder y relaciones de saber. (p. 8-9)

Si bien desde los planteamientos de Foucault el dispositivo tiene una connotación en inicio negativa, en tanto señala las técnicas físicas y discursivas del ejercicio de poder y disciplinamiento sobre los cuerpos y las relaciones, en el ámbito contemporáneo asistimos a una resignificación de este concepto, ampliando su sentido y ubicándolo, sobre todo, como eje central de formas de resistencia; lo que saca a flote una intrínseca connotación expresiva, que no era tan visible en sus primeros desarrollos.
De este modo, en el contexto de nuestra reflexión, la noción de dispositivo se configura, por un lado, como recurso de rememoración y resistencia al olvido, incluidas las demandas de verdad y justicia de parte de las víctimas del conflicto armado interno y, por el otro lado, como mediación expresiva frente a la experiencia de la violencia política. Una modulación que se sintoniza con lo planteado por autores como Agamben, Rancière o Deleuze, quienes ponen el acento en la funcionalidad y la expresividad del dispositivo, es decir, en el accionar que compromete su sentido político y su condición estética, en el marco de las dinámicas de interacción y las relaciones sensibles entre los sujetos y los contextos de inscripción de sus prácticas.

Es esta perspectiva desplegada a lo largo de nuestra reflexión, la que permite vincular tanto una comprensión ampliada de lo estético, como la condición funcional y expresiva del dispositivo como ejes visibles de algunas de las prácticas que procuran resignificar la experiencia vivida de la violencia política. De la misma forma, estas prácticas permiten ubicar a la víctima como mediador de la violencia política a través de una serie de prácticas, las cuales se tornan experiencias sensibles con el pasado, pero re-vitalizadas en el presente. En tal sentido, Cadahia frente a la tesis de la estética de Schilller, plantea las implicaciones del dispositivo y su rol en la mediación sensible:

Desde esta perspectiva, el dispositivo no funciona tanto como una red que captura, sino más bien como una experiencia sensible que resulta de la articulación de maneras de ver, decir y pensar. No se trata tanto de liberarse del dispositivo y devolver al ser viviente un espacio de anomia, esto es, un espacio originario, sino de problematizar los diferentes tipos de experiencia sensible que propician los dispositivos. Es decir, la disposición estética, al no re-presentarse, al no reiterarse como un mecanismo de repetición de lo dado, problematiza el ámbito de la re-presentación que otro tipos [sic] de disposiciones asumen como tal (2016, p. 272)

Vincular el diseño y la ritualidad alrededor de este dispositivo como recurso ante la experiencia sensible con el pasado, implica entender que esto no se da siempre como evocación intencional, sino que también se puede presentar como emergencia contenida por la víctima; más aún 
cuando hablamos de acontecimientos que narran el dolor de lo vivido. Esto significa, como lo señala Cadahia, diferenciar el tipo de experiencia sensible en cada caso, ya que su relación-sujeción con la memoria se teje, se escribe, se narra, se camina, en distintas procesiones con lo acontecido.

Así, una de las conclusiones fundamentales en este sentido es que la consideración sensible y la emergencia de las prácticas estéticas no configuran un recurso generalizable que opere de la misma forma para todos los grupos sociales. Cada dispositivo estético se define desde una aproximación particular, desde un posicionamiento específico frente a la experiencia de la violencia política, la cual, a lo sumo permite cimentar un vínculo comunitario o colaborativo. Su punto convergente radica en la dimensión catártica que se esconde en el proceso, mas su intención es singular para cada caso. Cada mediación despliega prácticas propias que al revisarlas en el marco del análisis relacional que acompaña el producto estético ya sea un performance, cuento, peregrinación, poesía, diario o tejido, necesita ser comprendido en el marco del ritual que, como se mencionó previamente, es una forma de re- presentación del pasado, como acontecimiento que cumple la función de la mediación en el presente.

Las prácticas estéticas a las que hemos hecho referencia constituyen formas de reivindicación y afirmación política de las víctimas frente a sus demandas en el contexto de la interacción con los otros. No solo se trata de re-presentar estéticamente lo vivido, sino de comprender el valor activo de la subjetividad, de su condición de víctimas en la búsqueda por el reconocimiento de la verdad y la justicia, tal como puede apreciarse en el caso de las peregrinaciones de Trujillo; de la denuncia, en el caso del performance del artista Yulián o de la acción de narrar como acción de catarsis expresada en el espacio público, como llamado a la no repetición en el caso de la escritura para Hugo y Jhonatan; o la resistencia social como en el caso de otras organizaciones de víctimas en el país.

La distancia frente al momento en el que tuvo lugar el acontecimiento violento permite, además del carácter ritual que cobra sentido en el marco de la práctica estética, la emergencia de un carácter reflexivo, una ubicación con mayor claridad de los actores que intervienen, las causas, los responsables y las elecciones que les permiten sobrevivir, es decir, acepta comprender la relación política compleja que supera el dispositivo mismo.
Nuestra aproximación metodológica procuró ir más allá de la mirada cosificada de la víctima por medio de un texto, un video, un cuento, un performance, etc. A través de la estructura misma del ritual, antes, durante y después, podemos entender la relación política del dispositivo, las diversas prácticas como recursos en la mediación del pasado y las distintas formas de abordaje del dispositivo estético. Al respecto, la investigación cualitativa, nos permitió la consolidación de una mirada dialógica en relación con las experiencias de las víctimas, a través de sus propias formas de nombrar y dar sentido a sus vivencias, lo cual, complementado con el trabajo de observación, la elaboración de diarios de campo, el análisis del producto desde la versión directa de sus creadores y, ante todo, la posibilidad de una mirada reflexiva sobre las implicaciones de sus prácticas y elaboraciones de sentido. Este último elemento permitió concluir que, a pesar de tener intenciones diversas con el proceso, su búsqueda y su alcance pocas veces son analizados de forma crítica. En fin, comprendimos que a través de este tipo de investigaciones ampliamos y nutrimos las miradas sobre aquello poco explorado que moviliza cada obra más allá de su contexto.

Finalmente, la conclusión más significativa del proyecto radicó en el diálogo permanente de un equipo, el cual encontró que las mediaciones pueden desplegarse en prácticas distintas con actores sociales diversos, asociaciones, artistas o víctimas, los cuales poseen vínculos y sensibilidades propias y/o diferentes, pero que encuentran en los dispositivos expresivos del arte y la estética, dispositivos fundamentales para hacer lugar a la memoria, para ubicar la subjetividad en perspectiva amplia, sin la clásica y reducida versión víctima-victimario; al contrario, como una oportunidad-responsabilidad de entender-nos todos como posibles mediadores, dinamizadores o receptores de la comprensión de un conflicto que no cesa y que debe entender que su primer paso con la verdad y la justicia implica la no-repetición, para que podamos algún día mediar con lo vivido y no con lo viviente. Qué mejor vía que apoyarse en la estética y en sus prácticas contemporáneas más profundas y reveladoras, para ir más allá del testimonio y el drama de los implicados en él. 


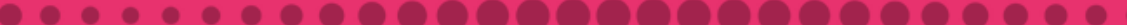

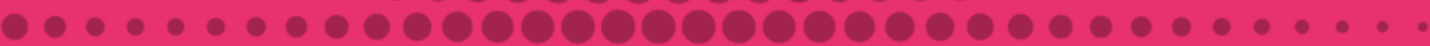

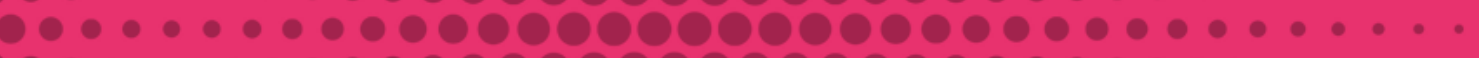

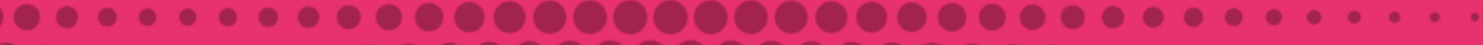

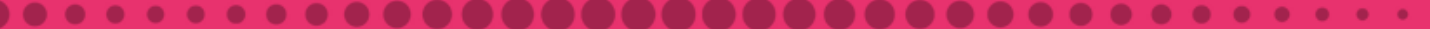

\section{Referencias bibliográficas}

Agamben, G. (2014) ¿Qué es un dispositivo? Buenos Aires. Adriana Hidalgo.

Bal, M. (2014). De lo que no se puede hablar. Universidad Nacional de Colombia, sede Medellín.

Cadahia, M. L. "Dispositivos estéticos y formas sensibles de la emancipación.” Ideas y Valores 65.161 (2016): 267-285.

Debray, R. (1997). Transmitir. Buenos Aires: Ediciones Manantial.

Rancière, J. (2010). El espectador emancipado. Buenos Aires: Ediciones manantial.

Rancière, J. (2011). El malestar en la estética. Capital Intelectual.

Rancière, J (2011). El reparto de lo sensible. Estética y política. LOM Ediciones 
Las prácticas artísticas y las expresiones estéticas han devenido campo de comprensión clave para valorar la manera como los grupos sociales exteriorizan sus expectativas de sentido y ponen en relación las experiencias afectivas que le dan soporte vivencial a su existencia. En contextos de gran complejidad como los que ha generado la violencia política y el conflicto armado en Colombia, es común encontrar que las comunidades recurren a prácticas simbólicas o a formas de agenciamiento de la vida social, cuyo valor no se puede entender por fuera del marco reflexivo y sensible que nos ofrece la estética.

En el mismo camino, una parte de los procesos creativos que ocupan a los artistas contemporáneos, se han afianzado en vínculos estrechos tejidos en torno a los relatos y experiencias de las víctimas de la violencia. Esto ha contribuido a propiciar un doble juego configurador de carácter estético y político: por un lado, la materialización de procesos expresivos y de traducción de experiencias derivadas del drama que viven las víctimas $y$, por otro lado, la consolidación de un archivo de registros, enteramente transmisible, que actúa como memoria colectiva o sistema de referencias interindividual de un contexto y un espacio-tiempo particular.

Este libro propone una serie de rutas comprensivas sobre algunas de las formas de mediación estética y expresiva construidas por artistas, sobrevivientes y grupos sociales en torno a experiencias ligadas con la violencia política y el conflicto armado en Colombia. Su propósito es aportar una mirada reflexiva a la forma como el testimonio y los relatos de tantos hechos dolorosos, se traducen en imágenes, encuentros afectivos y acciones rituales, necesarios para resignificar las memorias y sus registros.

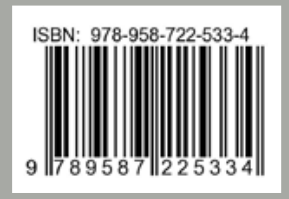

